

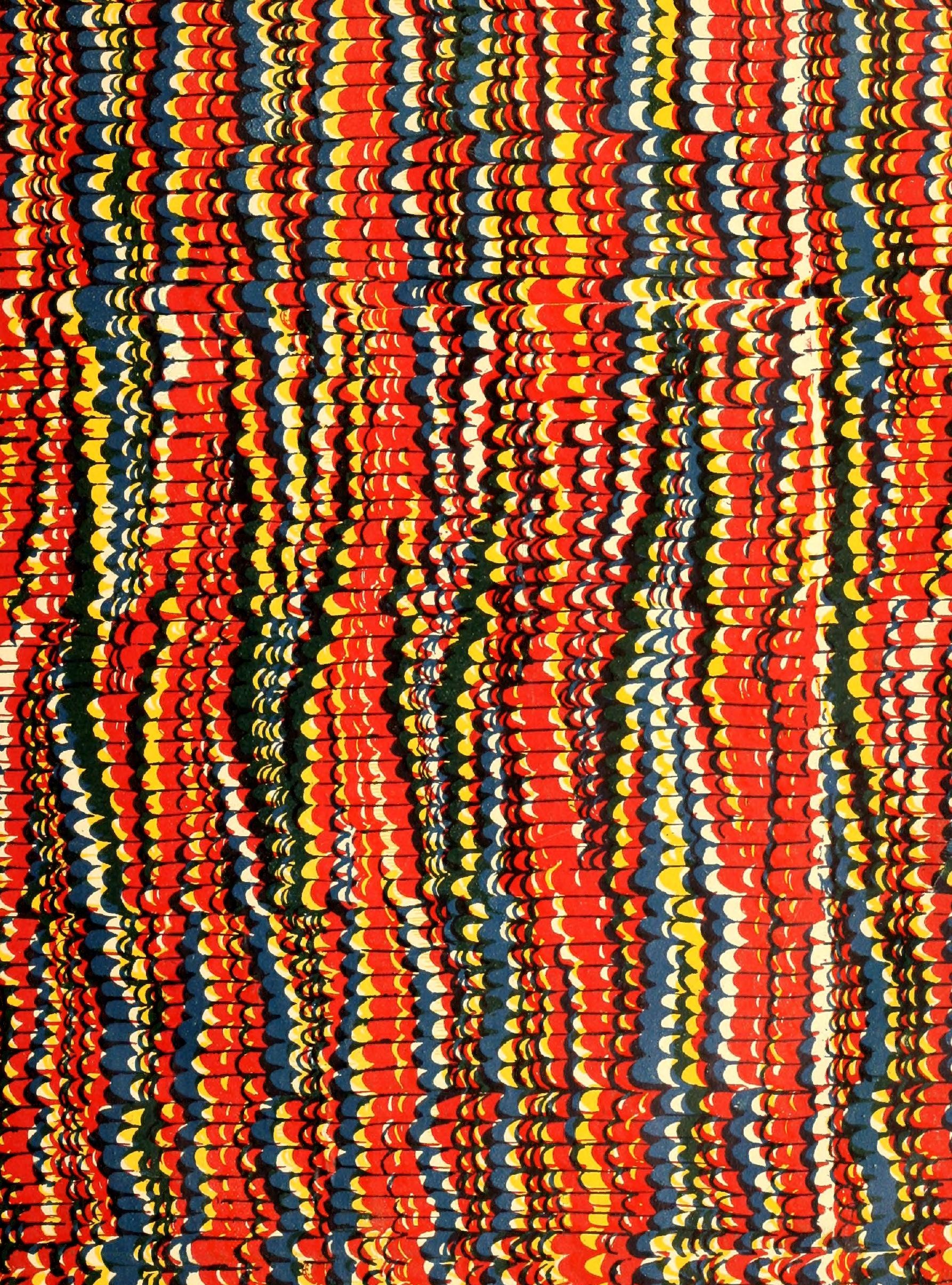



Dívistion of Molluches

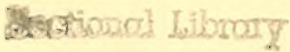






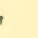


Mémoires de l’Académie Royale des Sciences et des Lettres de Danemark, Copenhague, $7_{\text {me }}$ série, Section des Sciences, t. V, no 3

\section{THE DANISH EXPEDITION TO SIAM 1899-1900}

\section{Marine \\ by \\ Herman Lynge \\ With 5 plates and a map}

Lamellibranchiata

D. Kgl. Danske Vidensk. Selsk. Skrifter, 7, Rakke, naturvidensk. og mathem Afd. V. 3

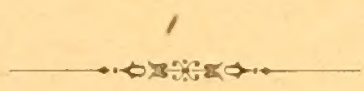

KOBENHAVN

HOVEDKOMMISSIONER: ANDR. FRED. HØST \& SØN, KGL. HOF-BOGHANDEL

BIANCO LUNOS BOGTRYKKERI 


\section{Det Kgl. Danske Videnskabernes Selskabs Skrifter, $6^{\text {te }}$ Række. Naturvidenskabelig og mathematisk Afdeling.}

I, med 42 Tavler, $1880-85$

1. Pryiz, K. Undersøgelser over Lysets Brydning i Dampe og tilsvarende Vædsker. 1880.........

2. Boas, J. E. V. Studier over Decapodernes Slægtskabsforhold. Med 7 Tavler. Résumé en français. 1880

3. Steenstrup, Jap. Sepiadarium og Idiosepius, to nye Slægter af Sepiernes Familie. Med Bemærkinger om to beslægtede Former Sepioloidea D'Orb. og Spirula Lmk. Med I Tavle. Résumé en frangais. 1881

4. Colding, A. Nogle Undersagelser over Stormen over Nord-og Mellem-Europa af 12te-14de Novb. $18720 \mathrm{~g}$ over den derved fremkaldte Vandflod i Østersøen. Med 23 Planer og Kort. Résumé en français. 1881

5. Boas, J.E. Y. Om en fossil Zebra-Form fra Bras̄iliens Campos. Med et Tillæg om to Arter af Slægten Hippidion. Med 2 Tavler. $1881 \ldots \ldots \ldots \ldots \ldots \ldots \ldots$

6. Steell, A. Integration af en lineær Dilferentialligning af anden Orden. $1882 \ldots \ldots \ldots$

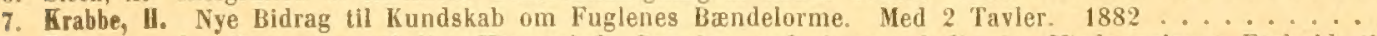

8. Hannover, A. Den menneskelige Hjerneskals Bygning ved Anencephalia og Misdannelsens Forhold til Hjerneskallens Primordialbrusk. Med 2 Tavler. Extrait et explication des planches en français. 1882

9. Den menneskelige Hjerneskals Bygning ved Cyclopia og Misdannelsens Forhold til Hjerneskallens Primordialbrusk. Med 3 Tavler. Extrait et explic, des planches en francais. $1884 \ldots . . .$.

10. - Den menneskalige Hjerneskals Bygning ved Synotia og Misdannelsens Forhold til Hjerneskallens Primordialbrusk. Med 1 Tavle. Extrait et explic. des planches en francais. $1884 \ldots \ldots \ldots$

11. Lebmann, A. Forseg paa en Forklaring af Synsvinklens Indflydelse paa Opfattelsen af Lys og Farve ved direkte Syn. Med 1 Tavle. Résumé en français $1885 \ldots \ldots \ldots \ldots \ldots \ldots$

II, med 20 Tavler, $1881-86$.

1. Warming, Eug. Familien Podostemaceae. 1ste Afhandling. Med 6 Tavler. Résumé et explic. des planches en francais. 1881

2. Lorenz, L. Om Metallernes Ledningsevne for Varme og Elektricitet. $1881 \ldots \ldots \ldots$

3. Warmlng, Eug. Familien Podostemaceae. 2den Afhandling. Med 9 Tavler. Résumé et explic. des planches en français. 1882

4. Christensen, Odln. Bidrag til Kundskab om Manganets Ilter. 1883 .

5. Lorenz, L. Farvespredningens Theori. 1883 .

6. Gram, J.P. Undersøgelser ang. Mængden af Primtal under en given Grænse. Résumé en francais. 1884

7. Lorenz, L. Bestemmelse af Kviksølvsøjlers elektriske Ledningsmodstande i absolut elektromagnetisk

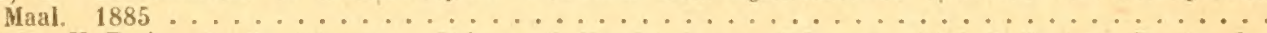

8. Traustedt, M. P. A. Spolia Atlantica. Bidrag til Kundskab om Salperne. Med 2 Tavler. Explic. des planches en français. $1885 \ldots \ldots \ldots \ldots \ldots \ldots \ldots \ldots \ldots$

9. Bohr, Chr. Om Iltens Afvigelser fra den Boyle-Mariotteske Lov ved lave Tryk. Med 1 Tavle. 1885 ...

10. - Undersogelser over den af Blodfarvestoflet optagne Iltmængde udforte ved Hjælp af et nyt Absorptio-

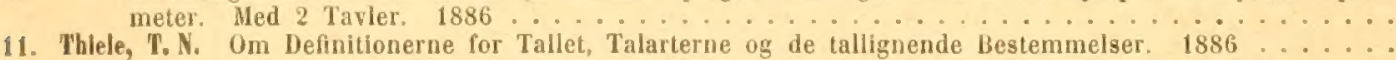

III, med 6 Tavler, $1885-86$

1. Zeuthen, H. G, Keglesnitslæren i Oldtiden. 1885

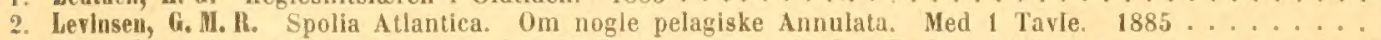

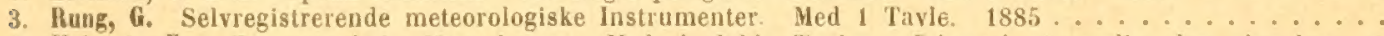

4. Melinert, Fr. De encephale Myggelarver. Med 4 dobb. Tavler. Résumé et explic. des planches en français. 1886

IV, med 25 Tavler. $1886-88$

1. Boas, J.E.V. Spolia Atlantica. Bidrag til Pteropodernes Morfologi og Systematik samt til Kundskaben om deres geografiske Udbredelse. Med 8 Tavler. Resumé en français, $1886 \ldots \ldots \ldots \ldots$

2. Lebmann, A. Om Anvendelsen af Middelgradationernes Metode paa Lyssansen. Med i Tavle. 1886. . .

3. Hannover, A. Primordialbrusken og dens Forbening i Truncus og Extremiteter hos Mennesket for Fodselen. Extrait en français. 1887

4. Lutken, Chr. THlæg til "Bidrag til Kundskab om Arterne af Slagten Cyamus Latr, eller Hvallusene*. Med 1 Tavle. Résumé en français. 1887

5. __ Fortsatte Bidrag til Kundskab om de arktiske Dybhavs-Tudsefiske, særligt Slægten Himantolopius. Med 1 Tavle. Résumé en français. 1887

6. Kritiske Studier over nogle Tandhvaler af Slægterie Tirsiops, Orca og Lagenorhynchus. Med Tavler. Résumé en francais. 1887

7. Koefoed, E. Studier i Platosoforbindelser. 1888

8. Warming, Eug. Familien Podostemaceae. 3die Afhandling. Med 12 Tavler. Résumé et explic. des planehes en français. 1888

V, med 11 Tavler og 1 Kort. $1889-91$

1. Luitken, Chr. Spolia Atlantica. Bidrag til Kundskab on de tre pelagiske Tandhval-Slægter Steno, Dél-

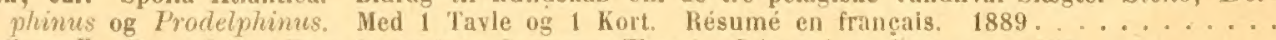

2. Valentiner, 11. De endelige Transformations-Gruppers Theori. Résumé en français. 1889......

3. Hansen, H.J. Cirolanidæ et familiæ nonnullæ propinquæ Musei Hauniensis. Et Bidrag til Kundskaben om nogle Familier af isopode Krebsdyr. Med 10 Kobbertavler. Hésumé en frangais. 1890....

4. Lorenz, L. Analytiske Undersegelser over Primtalmangderne. 1891

Kr. Bre

29. 50 .

- 65.

8. 50 .

1. 35 .

10.

2..

- 50.

1. 35 .

1. 60 .

4. 35 .

1. 30 .

1. 85 .

20.

3. 15.

1. 30.

5. 30 .

1. 10 .

- 60.

4. "

- 802

3 .

1. "

1. 70 .

2.

16.

10.

1. 10 .

1. 10 .

6. 75 .

21. 50 .

10. 50 .

1. 50 .

1. 60 .

- 60.

- 75.

4. 75 .

1. 30 .

6. 45.

15. 50 .

2. 75 .

5. 50 .

9. 50.

- 75. 


\section{THE DANISH EXPEDITION TO SIAIM 1899-1900}

D. Kgl. Danske Vidensk. Selsk. Skrifter. 7. Riekke, naturvidensk. og mathem. Afd. V. 3

\section{Marine \\ Lamellibranchiata ${ }_{244436}$ by \\ Herman Lynge}

With 5 plates and a map

København

Biancolunos Bogtrykkeri 

The present work upon the Lamellibranchiala collected by the Danish Expedition to Siam forms the first part of a description of all the testaceous Mollusca of the Gulf of Siam, which I hope to publish gradually, the description being based upon the excellent collections made by Dr. 'TH. Montensen during the Danish Expedition $1899-1900$.

I have thought it right to include in the present work all the species which have hitherto been recorded from the Gulf of Siam, even although not collected by the Danish Expedition to Siam.

I wish heartily to thank Mr. G. M. R. LEvinsen of the Zoological Museum of the University of Copenhagen for freely placing the collections of the Museum at my disposal; also I am much indebted to my friend at the Zoological Museum, Mr. AD. S. JENSEN, for his unfailing help in searching out material for comparison. Unfortunately, our museum in Copenhagen, although excellent in other respects, is not rich in Asiatic Mollusca which could have been of use to me for the sake of comparison. I was therefore very much pleased, when, during my sojourn in London (which I visited before finishing my work), I was able to avail myself of the much richer collections in the British Museum of Natural History, owing to the ready courtesy and kindness of Mr. EDGar Smith, to whom I tender my heartiest thanks. I am also indebted to Messrs. PH. Dautzenberg, Paris, to the late Professor ED. V. Martens of Berlin, and to J. Cosmo Melvill Esi. of Shrewsbury for information and intelligence.

To Dr. TH. Mortensen, who from the beginning has taken a great interest in my work, and has always been ready with advice and information, I wish to offer my hearty thanks, and also to express my appreciation of the way in which, during the Expedition and often under very difficult circumstances, he has got together such excellent collections, which have in so many ways enriched zoological science with valuable material.

Copenliagen, December $19(1) 8$.

HenM. Lynge. 


\section{Introduction.}

Our knowledge of the marine Lamellibranchiala of the Gulf of Siam was for a long time very limited. Thus, when Professor ED. V. Martens, in 1860, published his paper "On the Mollusca of Siam" in the "Proceedings of the Zool. Society of London," he mentioned in it only 7 species of marine Lamellibranchiata. Nor was our knowledge of the fauna enlarged until L. MorLet described Mr. PAviE's collections in the "Journal de Conchyliologie," 1889; but in 1891, when PauL Fischer published his "Cialiblogue el distribution gégraph. d. Mollusques terrestres, fluviatiles et marins d'une partie de l'Indo Chine"1 he was able to record 72 species of marine Lamellibranchiata from the Gulf of Siam, and this number has been increased to 85 species by PAvie's new collections, which Crosse \& Fischer, in 1892, described in the "Journal de Conchyliologie." By Dr. Th. Montensen's thorough and excellent dredgings and collections from the eastern part of the Gulf of Siam during the years 1899-1900, the number of known species of Lamellibranchiata from that place has now been increased to 379 species. But the fauna is without doubt still far from exhausted hy this last addition, because the Danish Expedition dredged only in the northern and eastern parts of the gulf, and only down to a depth of about 35 fathoms. The Molluse fauna in the western part and also in the deeper parts in the middle of the gulf is still unknown. It is true that the "Skeat-Expedition" has made collections on the Malacea side of the gulf, but the Mollusca of these collections have not yet been worked out. Thus, as it is only the littoral fauna of a part of the gulf which is known, it must be understood that the present list is only the beginning of a complete list of the species occurring in the gull. Though it may be supposed that the littoral faun of the northern and eastern parts of the gulf is now almost completely known, yet it is probable that the fauna of the western side of the Gulf of Siam is richer, and contains many species which have not hitherto been taken on the eastern side. This is owing to the fact that the water on the Malacea side is much purer and fresher than in the eastern part, where the outlets of the numerous rivers make the sea-water foul and muddy and also less saline."

1 Bulletin Soc. Hist. Nat. d'Autuu. IV, 1891, Pp. 87-276.

2 Cf. Th. Montenses, "The Danish Expedition to Sian, 1899-1900, Results of the zoological Collections." Kgl. Danske Vidensk. Selsk. Skrifter, 6. IR. Naturv. og mathem. Afd. XII, 2, 1902, pp. $155-57$. 
On comparing the Lamellibranchiata hitherto described from the Gulf of Siam with those of other more thoroughly investigated parts of the Asiatic waters, we find, according to Melvill \& STANDEN, that 426 species (among which are many deep water forms) are recorded from the Persian Gulf, the Gulf of Oman, and the Arabian Sea. Besides the fact that this fauna has many species in common with that of the Gulf of Siam, the two faunas correspond in many points with each other in regard to character. Unfortunately, J. G. Hidalgo's work on the Lamellibranchiata of the Philippines is not yet finished, so no definite number of species can be recorded from that place. In CASTO DE ELERA's uncritical "Catálogo sistemát. de toda la Fauna de Filipinas," III, 1896, more than 800 Lamellibranchiata are recorded from the Philippines. From Japan, PILsBRy gives in 1895 over 500 species in his "Catalogue of the Marine Mollusks of Japan," and he has afterwards added several to these.

The new species and varieties which will be described in the following pages are:-

Arca (Barbatia) Siamensis.

- (Anadara) Mortenseni.

- (Scapharca) dichotoma Desh. var gratiosa.

Carditella pusilla.

- pulchella.

Lucina (Phacoides) Dalli.

- (Phacoides) pulchella.

Kellya lineata.

- rosea.

- vitrina.

- elongata.

lilium.

Montacuta costata.

- venusta.

(Tellimya) variabilis.

- (Tellimya) rudis.

Tellina (Arcopagia:) Smithi.

- Merisca) Martensi.

- (Moerella) Berghi.

- (Macoma) tenuisculpta.

Circe Melvilli.

Chione (Timoclea) Siamensis.

Hemicardium (Fragum) frugum L. var, carinata.

Corbula lineata.

- arcaeformis.

- (?) mirabilis.

Sphenia quadrangularis. 
If we draw any conclusions concerning the character of the whole fauna, we may confidently say, even if convinced that it is but imperfectly known, that it belongs entirely to the Indo-Pacific Fauna. I do not think forms occur which are peculiar to the Gull of Siam; if so, they may possibly be some of the species of the Mangrove fauna (e.g. Lucina Dalli m.), but I do not believe even these to be peculiar to the Gulf of Siam, they can without doubt be found also in other similar localities in Indian waters.

The classification is partly that proposed by Professor $\mathrm{P}^{2}$. PELseneEr in 1894 in his "Introduction à l'étude d. mollusques", which is based on the study of the comparative anatomy of the more minute details of the gills; not that I consider it to be quite satisfactory, bul, unfortunately, that is true of all other older systems of the Lamellibranchiata. I have ventured upon some alterations in his system; for instance, I have not reckoned Psammobia to Myacea, as he does, but placed it under Tellinacea, to which it belongs more closely, judging from other systematic characters. I have retained Pinna under Pteriidae, to which it most naturally belongs, and not in the neighbourhood of Ostrea and Lima where Pelseneer would have it. "To employ the structure of the gills exclusively as the basis of a classificatory system 2 , without taking other features inlo consideration, especially the structure of the hinge, is in my opinion absolutely wrong in the case of the Lamellibranchiata.

1 And afterwards revised in his "A Treatise on Zoology, ed. by E. Ray Iankesten, V. Molluscat by" P. PELSWNEER, LOHdOn, 1906.

"Cf. E. L. Kick, "Dic systemat. Verwertbarkeit.d. Kiemen bei d. Lamellibranchiaten." Jenaische Zeitschrift f. Naturwissenschaft, 31. 13d, 1898, p. 29. 


\title{
Order Protobranchiata.
}

\author{
Fam. Nuculidae.
}

Nucula Cumingi, Hinds.

Nucula Cumingii, Hinds, Proc. Zool. Soc. London, XI, 1843, p. 97.

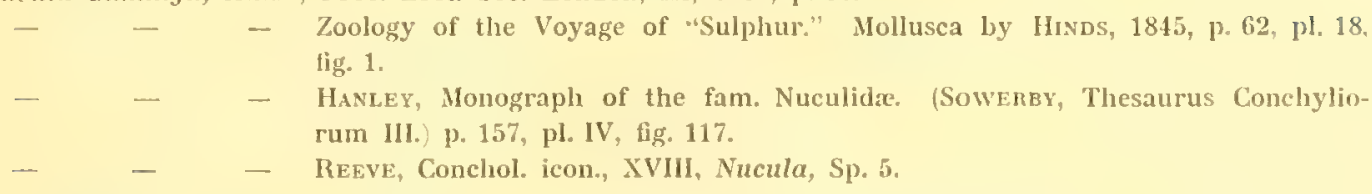

The Gulf of Rayong and Cape Liant. Common around Koh Kut and Koh Kahdat, 4-30 fathoms, sand, mud and shells. ${ }^{1}$

Long. 4-12 $\mathrm{mm}$.

Distribution:- Singapore, Strait of Malacea, Philippines, New Guinea, Strait of Macassar.

Nucula Layardi, A. Ad.

Nucula Layardii, A. Abams, Proc. Zool. Soc. London, XXIV, 1856, p. 51.

- Layardi, - Hanley, Monogr", of the fam. Nuculida (Sowerbr, Thesaurus Conchyl., III.) p. 160, pl. V, fig. 153 .

- - - ReEve, Conchol. icon. XVII. Nucula. Sp. 36.

- Edg. Smitr, Ann. and Magaz. Nat. Hist., 7. Ser., XVIII, 1906, p. 252.

West of Koln Chuen, soft clay and mud. (3/2). ${ }^{2}$ The Sound of Koh Chang, 3-5 fathoms, soft clay (many specimens). The coast of Lem Ngob, low tide (1/9). Long. 4-10 $\mathrm{mm}$.

Distribution:- Ceylon, Bombay, Karachi, Mekran Coast, Gulf of Oman, Persian Gulf.

REEve (loc. cit.) is correct in saying that the present species is much more nearly allied to $N$. Cumingi than to $N$. convexa (as stated by A. ADAus). "The outline of $N$. Layardi corresponds almost completely with that of $N$. Cumingi. 'The number of the hinge-teeth ("six in front and nineteen behind") stated by EDG. SMITH (loc. cit.) to occur in his "single shell", which measured $15 \mathrm{~mm}$. in length, is not always constant, more or fewer teeth frequently occurring. Undoubtedly the age, size and development of the individual also have a share in regard to this feature.

I In the list of localities "sand," "mud", "stones," etc. stand for "sandy bottom," "muddy bottom," "stony bottom," etc.

t The number in parenthesis indicate throughout the number of specimens collected. 


\section{Yoldia tenella, Hinds.}

Vucula tenella, Hinos, Proc. Zool. London, XI, 1843, p. 99.

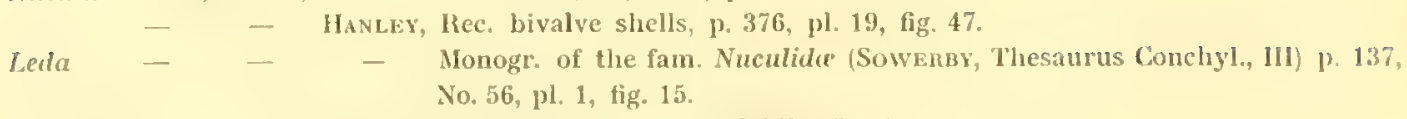

Yoldia - - HeEve, Conchol, icon., XVIII, Yoldia, Sp. 4.

Kol Chuen, 10-15 fathoms (1/2). West of Koh Chuen, soft clay and mud $(1+4 / 2)$. East of Koh Mak, 20 fathoms, mud ( $\left.{ }^{1 / 2}\right)$. WV. of lioh Kut, 30 fathoms, sand and mud $(5 / 2)$. N. of Koh Kut, 10 fathoms, mud $\left({ }^{1 / 2}\right)$.

Long. 4-11 mm.

Distribution:-- Singapore, Gulf of Oman (Merrilu d Standen).

Yoldia serotina, Hinds.

Nucula serotima, Hinis, Proc. Zool. Soc. London, XI, 1843, j. 99.

Ifela - - Sowfisy, Thesaurus Conchylionum, II, 1866, Monogr, of the fam. Nuculider hy HaNley, p. 136 , No. 54, pl. 1, tigs. 19-21.

Yoldia

Leda lepida, A. Adans, ReEve, Conchol. icon., XVIII, Yoldia, Sp. 5.

Proc, Zool. Soc. London, XXIV, 1856, p. 49.

South of Koh Kut, 17-20 fathoms, mud (1/2).

Long. $4 \mathrm{~mm}$.

Distribulion:- Singapore, Gulf of Oman (Melvill \& Standen). - Philippines, Borneo.

\section{Nuculana Belcheri, Hinds.}

(I)1. 1, Figs, 18-19).

Nucula Belcheri, IHsns, ['roc. Zool. Soc. London, XI, 1843, p 98.

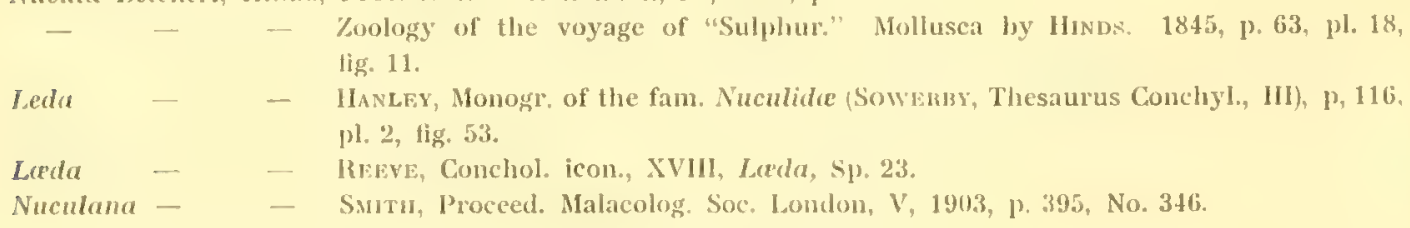

The Sound of Koh Chang, 5 falhoms, soft clay. (1/2).

Long. 10 1111 .

Distribution:- Agulha Bank, Cape of Good Hope (Belcher), oll Cape Colony and Natal, 34-440 fathoms (Evg. SMTH).'

The single valve obtained from the Gulf of Siam is not full-grown, therefore, as may be seen in P1. 1, Fig. 19, the characteristic central keel, which extends from the ventral side towards the umbo, is absent at the posterior end: this agrees entirely with the opinion expressed by HANideY (loc. cit, p. 117) "As the central keel does not extend to the umboes, it is probably wholly absent in the fry."

1 On South African Marine Mollusca. (Amuals of the Natal Covernment Museum. Vol. 1, p. 1, 1906). 


\section{Nuculana puellata, Hinds.}

Nucula puellula, Hinns, Proc. Zool. Soc. London, XI, 1843, p. 100.

Zoulogy of the voyage of "Sulphur." Mollusca by HiNus, 1845, p. 64, pl. 18, fig. 18 .

Leda - Handey, Monogr of the fam. Nuculide (Sowerby, Thesaurus Conchyl., III), p. 127, pl. 3, lig. 94 .

Lededa - - IREEvE, Conchol. icon., XVIli, Leda, Sp. 34.

Koh Chuen, 10-15 fathoms (common). W. of Koh Chuen, soft clay and mud (very common). S. of Koh Samit, 20 fathoms, mud (1/2). Sound of Kolk Chang, 3 -5 fathoms, soft clay (common). West coast of Koln Chang, 10 fathoms, mud $(1 / 2)$. S. of Koh Bidang, 9 fathoms, mud (common). S. of Koh Kahdat, 8-10 fathoms, mud $(1 / 2)$. Between Koh Kahdat and Koh Kut, 6 fathoms, clay mixed with sand $\left({ }^{16 / 2} / 2\right)$ W. of Koh Kut, 15 falloms, mud $\left({ }^{4} / 2\right)$. N. of Kols Kong, 8 fathoms, mud (2). W. of Koh Kong, 10-15 fathoms $(2 / 2)$.

Long. $3-8 \mathrm{~mm}$.

Distribution:- Malacca, NE. coast of New Guinea (Brazier).

There is great variability in the length of the rostrum, and in some specimens it may be much longer than is shown in the figures given by Hinds and HaNLEY

REEvE's figure is very misleading, for the sculpture - which in reality consists of an exceedingly pretty, fine, regularly concentric striation - in his figure is lighly irregular and undulating.

Nuculana mauritiana, Sow.

Nucula Mauriliane, G. I3. Sowenвy jun., Conchological lllustrations, 1833, Nucula, p. 4, No. 22, fig. 17.

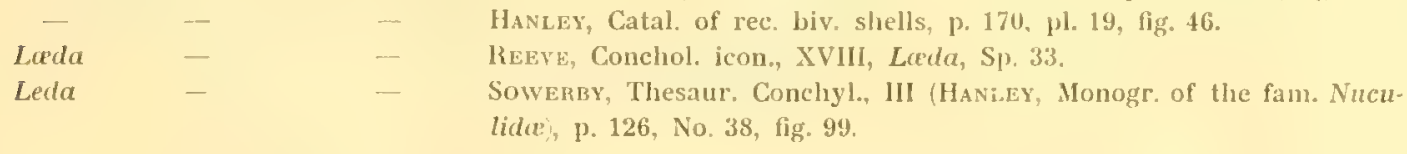

Between Koh Lan and Koh Kong, common, taken in great number in 6-30 fathoms, mud, clay mixed with sand, shells.

Long. $2-12 \mathrm{~mm}$.

Distribut ion:- Mergui Archipel., Ceylon, Bombay, Mekran Coasl, Mauritius. - China.

Many of the specimens from the Gulf of Siam bear a close resemblance to Nuculana nasuta, Sow.

\section{Nuculana retusa, Hinds.}

Vucula relusa, Hinds, Proc. Zool. Soc. London, XI, 1813, p. 99.

- - - Zoology of the voyage of "Sulphur." Mollusca by Hinus, 1845, p. (6i3, pl. 18, fig. 9.

Leda (Portlandia) retusa, Hinds, Handey, Monograph of the fam. Nuculide (Sowbiby, Thesaurus Conchyl. III). p. 146, No. 71, pl. 2, figs. 28-29.

Yoldia relusa, Hixds, H. \& A. AdAss, Genera of rec, Moll., II, 1858, 11. 548.

- Rrsve, Conchol. icon., XVII, Yoldia, Sp. 21. 
East of Koh Chnen, 9 fathoms (1).

Long. $1.75 \mathrm{~mm}$.

Distribution: - Strait of Malacca. - Philippines.

\section{Order Filibranchiata.}

\section{Fam. Anomiidae.}

Anomia sol, Reeve.

(Pl. 1, Figs. $1-2)$.

Anomia sol, ReEve, Conchol, icon., vol. XI, Anomia, 1859, Sp. 4 .

- Crosse et Fiscuen, Journ. de Conchyl., vol. 37, 1889, p. 290.

Coast of Lem Ngob (3). Gulf of Klong Salakpel (3). W. of Koh Kut, 30 falloms, sand and mud.

On stones and shells (for instance on Perna Cumingi, Reeve).

Long. $57 \mathrm{~mm}$., alt. $51 \mathrm{~mm}$. (sp.max.).

Long. $8 \mathrm{~mm}$., alt. $8 \mathrm{~mm}$. (sp. min.).

Distribution:- Kurachee (Indus.). -- Annam.

The upper valve, in the specimens from the Gulf of Siam, has a peculiar wrinliled (in the younger specimens nodose) appearance; the interior has a nacreous lustre. A. plenilunium, Reeve (from Borneo, Mcrgui Isls. and several other places) is, no doubt, only A. sol, Reeve, although ReEve states that "l'he under valve is tumidly raised about the orifice, with flexuous lines diverging around;" this is undoubtedly only an individual characler.

\section{Anomia amabaeus, Gray.}

(['], 1, Figs. 3-4).

Anomia amaberes, Gray, Proc. Zoul. Soc. London, XVII, 1849, p. 115.

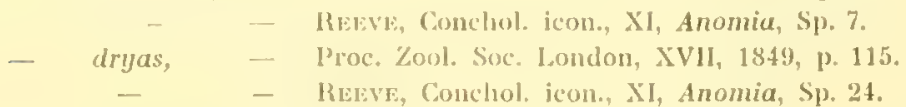

Koh Lan, 30 fathoms, mud (1). Between Koh Rin and Clifl Rock, 15 fathoms (1). The northern side of Koh Mesan, 10-15 fathoms, stones (3). S. of Koh Chuen, 30) falhoms, shells (2). Between Koh Kut and Koh Kahdat, 10 fathoms, shells (3).

Long. $18 \mathrm{~mm}$, alt. $21 \mathrm{~mm}$. (sp. max.).

Long. $8 \mathrm{~mm}$, alt. $8 \mathrm{~mm}$. (sp. min.).

Distribution:--. Singapore (A. dryas), Philippines (A. amabaeas). 
Judging from the material at hand, and after having examined the original specimens in the British Museum, I cannot see that there is any difference between Gray's two species A. amabaeus and A.dryas (some specimens from Koh Mesan agree almost completely with ReEve's $A$. dryas). The hinge in the species we are here considering presents a peculiar feature, which may be seen in Pl. 1, Fig. 4; there is, in the upper valve a keel which extends internally from the point of attachment of the ligament to the dorsal margin of the valve, a similar case I have neither met with, nor seen described, in any other species of Anomia. The umbones are situated at some distance from the margin of the valves.

\section{Anomia (Aenigma) aenigmatica, Ch.}

Tellina aenigmatica, Cuemsitz, Conchyl. Cabin., XI, 1795, p, 211, pl. 199, figs. 1949-50.

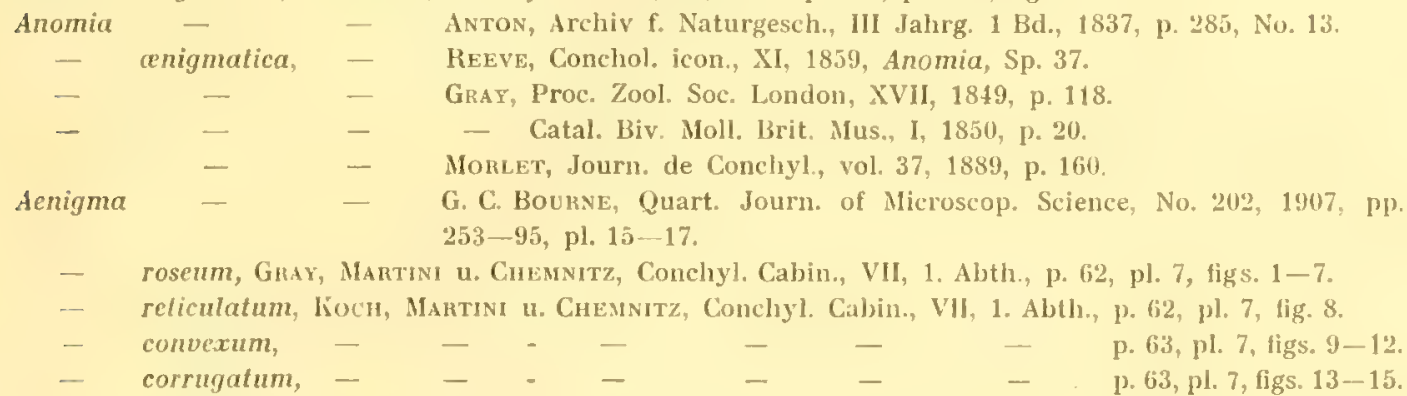

"Palmiers d'eau à Kanipol (o: Kampot) Golfe de Siam" (L. Morlet).

Distribution:-- Singapore, Delta of Irawady (Pegu, Burma), Bombay, Karachi, Persian Gulf. - Philippines, Borneo.

The Danish Expedition to Siam collected no specimens of this species.

\section{Placuna placenta, L.}

Anomia placentu, Linné, Systema Naturae, ed. X, 1758, p. 703, No. 205, ed. XII, p, 1154, No. 241. Mus. Ludov. Ulricae, 1764 , p. 536 , No. 126.

Plucuna - - LaMARCk, Hist. nat. d. anim. s. vert., VI, 1 p. 1819, p. 22 t, No. 3, cid. 2, VII, p. 270, No. 3.

$-\quad$ Encyclop. méthod., pl. 173.
$-\quad$ Mantinı u. Chemnitz, Conchyl. Cabin., VII, 1. Abth., p. 66, pl. 5, fig. 3.

- - - Reeve, Conchol. icon., XVIII, Placuna, Sp. 3.

P. Fischer, Catalogue d. Moll. de l'inlo-Chine, p. 20).

- - - Hornelr, Rep. Ceylon Mar. Biolog. Laboratory, I, p. 2. 1906, p. $\$ 1$.

Placenla orbicularis, Rerzius, Diss. sist. nova testaceorum genera. Lund, 1788, 1\% 15.

Melvili, and Standen, Proc. Zool. Soc. London, 1906, p. 793.

Ofl Koh Kam, 10 fathoms, gravel (1/2). S. of Koh Samit, 20 fathoms, mud $(2 / 3)$. IV. of Koh Chang, 20 fathoms, mud (1). Sound of Koh Chang, 3-5 fathons, soft clay (many specimens). Coast of Lem Ngob (3). S. of lioh liut, 17-20 fathoms, mud (2). N. of Koh Kong, 8 fathoms, mud (4).

"Les grèves du golfe de Siam" (MonLET). 
Long. 5-85 1111 .

Distribution: -- Singapore, Mergui Archip., Andamans, 'Tranquebar, Ceylon, Panjim and Goa, Bombay, Karachi, Persian Gulf, Aden. - Annam, Poulo-Condol, Philippines, China, Japan, North, East and West Australia.

$P l$. auriculata, Yoldi ${ }^{1}$ from the Red Sea is only a form of Pl.placenta L. which anteriorly and posteriorly is llattened in an ear-like manner above the dorsal margin. Such forms also occur among the specimens from the Gull of Siam. A. Willey (loc. cit. p. 37, Fig. 1) mentions and figures specimens of $P$. placenla from Ceylon with such ear-like lobes occurring on either side of the hinge-line, especially in young individuals.

\section{Placuna papyracea, Lam.}

Ephippium parvum papyracenm Anglicasum seu Polonicum, CuEmstz, Conchyl. Cabin., VIII, 1785, p. 114, 11. 79, fig. 715

Placuna papyracea, Lamanck Hist. nat. d. anim. s. vert., VI, p. I, 1819, p. 224. - éd. 2, 1836, VII, p. 270. - $\quad$ - $\quad$ - Encyclop. méthod., pl. 174, fig. 2.

- - - Martini u. Chemeitz, Conchyl. Cabin., vil, 1. Albth., p. 65, pl. 5, fig. 2.

Placenta quadrangula, ReTzius, Diss. sist. nova testaceor. genera, 1788, p. 16.

Koh Lan, 30 lathoms, mud (1). Between Koh Rin and Clill Rock, 15 fathoms (7). N. of Koh Kam, 5 fathoms, gravel (12). Last of Cape Liant, 9 fathoms, shells (1). Koh Chuen, 30 fathoms (2). Koh Kahdat, 1-5 lathoms, sand wi!h slones (1).

Long. $19 \ldots 84 \mathrm{~mm}$.

Distribution: - Mergui Archip. - Philippines, Amboina(?), Aru Isl., Sorong, Australia.

REEvE, and J. E. GRAY ${ }^{3}$ attribute much importance to the reciprocal length of the two hinge-teeth, to lheir position with reference to each other, and to the angle formed by them; in the case of young individuals these can by no means be used as specific characters (in older specimens they may be employed as such); in specimens, for example, of $P$. papyracea, Lam. and P. placenta I. (of about $20 \mathrm{~mm}$. in breadth) from the Gulf of Siam, there is no difference whatever with regard to these points: on the olher hand, the sculpture and consistency of the shell, which in most cases is characteristic in each species of Placuna, is a far better specific character, being also conslant.

\section{Placuna (Placunema) sella, Gmel.}

Ephippinm anglicanum maxinum, Cusmstr\%, Conchyl. Cabin., VII, 1785, p. 111. pl. 79, fig. 714. Anomia Sella, (imbur, Systema Naturac, ed. Xlll, 1790, p. 3345, No. 27.

Placuna sella, - I.AMAHck, Hist. mat. d. anim. s. vert., VI, p. I, p. 224. - éd. 2, VII, p. 270. (oollection.

1 Moncu, Catalog. conchyl. qua reliq. com. de Yoldi, 11, p. 63. The original sprecimen is in my

2 Spolia \%eylanica, vol. V, part XVII, Colombo, 1907, p1. 33-57.

Proc. of the Zool. Soc. London, XVI, 1818, p. 111. 
Placuna sella, Gimetin, Encyclop. méthod., pl. 174, figs. 1 et $3-4$.

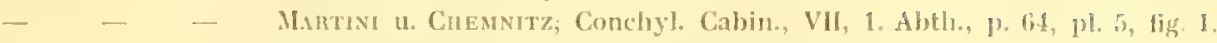

- - - lieeve, Conchol. icon, XVIII, Plachna, Sp. 1.

- - _ P. Fischen, Catal. d. Moll. de IIndo-Chine, p. 208.

Placenta Ephippium, Retzius, Diss. sist. nova testaceor. genera, 1788, 1. 16.

"Les grèves du golfe de Siam" (Morlet)."

The Danish Expedition to Siam collected no specimens of this species.

D istribulion: - Singapore, Mergui Archip. - Philippines, China, Java, Blilong (post-tertiary), Celebes, Amboina, Obi Isls., Pelew Isls.

\section{Fam. Arcidae.}

\section{Arca navicularis, Brug.}

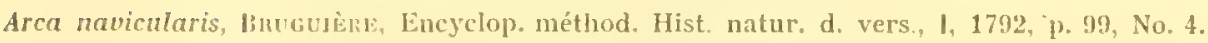

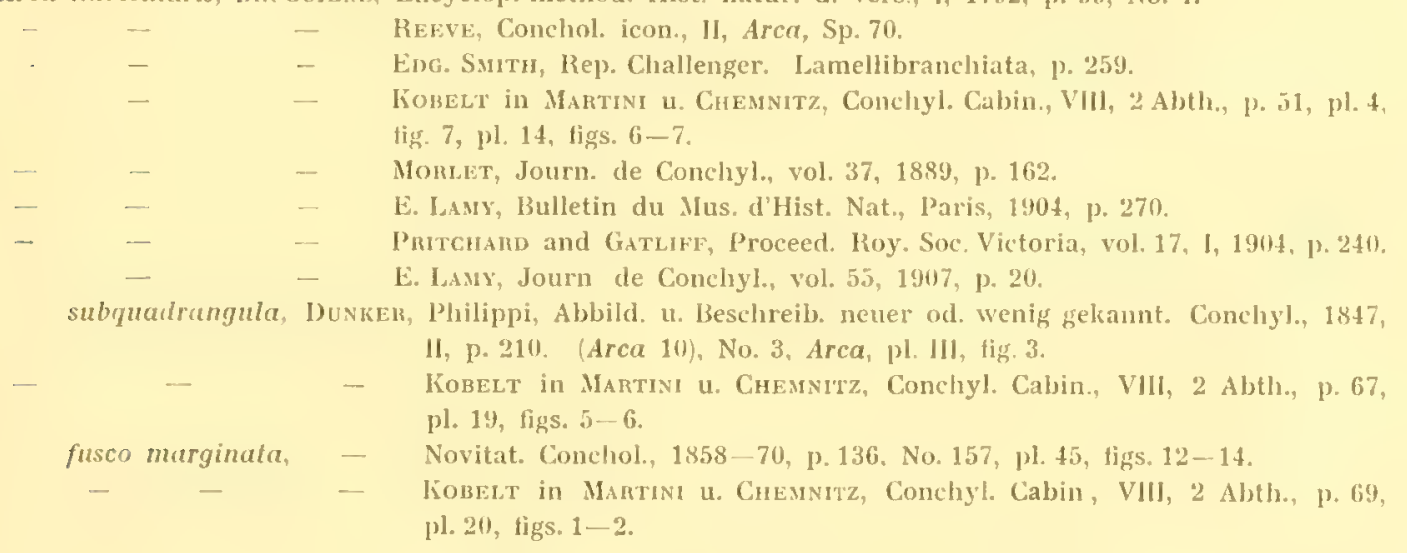

\section{var. linter, Jonas.}

Arcu linter, Jonas, Zeitschr. f. Malakozool., 1845, p. 172.

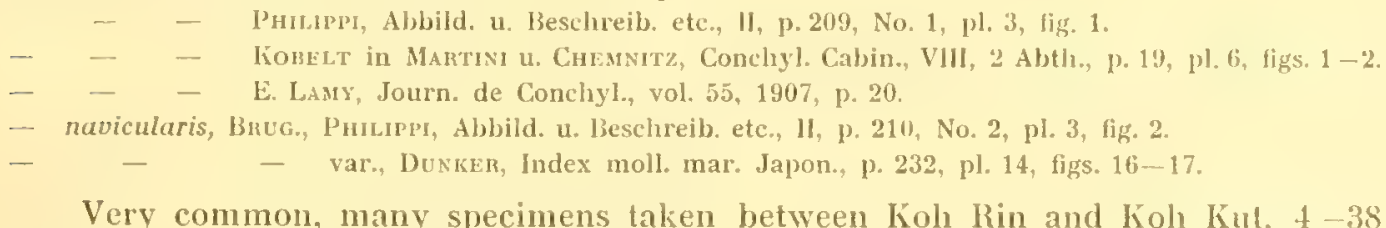
fathoms, shells, stones, mud and sand.

Islands in the Gulf of Siam (L. Morlet).

Long. 2-59 $\mathrm{mm}$.

Distribution: - Gulf of Manaar, Aden, Suez, Madagascar (Voertzkow, Lamy), Durban (EDg. Smith). - Poulo Condor, Cochin China, China, Japan, Amboina, Blitong (post-tertiary), Torres Strait, North, East and South Australia, Tahiti, Salomon Isls., New Caledonia.

1 Journal de Conchyliologie, 1889, vol. 37, p. 161. 
For var. linter, E. LaMY gives the following distribution:- Nossi Bé, Isle of Bourbon, China, Macao.

In the matter of synonymy I have followed LAMY with regard to navicularis as compared with linter, although I am of opinion that the latter is merely a variation of the former. In all the specimens from the Gulf of Siam the ligament upon the area had the form figured by PHiLipPI (loc.cit.) in Pl. III, Fig. 1.

\section{Arca Kraussi, Phil.}

Arca Kranssii, P’hlippl, Ǩnauss, Die südafrikan. Mollusken, 1848, p. 14, pl. 1, fig. 13.

Abbild. u. Beschreib. neuer od. wen. gekannt. Conchyl., III, 1851, p. 88 (20), pl. 5, figs. $8-10$.

Koh Kram, 30 fathoms (1). Between Koh Mesan and Koh Chuen, 15-38 fathoms, stones (2). Koh Chang, stones, very low tide (1). Koh Lom (1). Koh Mak, sand coast $(1 / 2)$.

Long. 9-27 mm. (For comparison with the measurements quoted by LischkE: Jap. Mecres Conchyl., II, P. 142, I give the measurements of a specimen from between Koh Mesan and Koh Chuen. The length of the shell $27 \mathrm{~mm}$., the height $15 \mathrm{~mm}$, the length of the area $22 \mathrm{~mm}$., the breadth of same $9 \mathrm{~mm}$.).

Distribution:- Mergui Archipel., Gulf of Manaar, Djibouti, Red Sea, Seychelles, Mascarenes, Querimba Isls., Natal. - Poulo Condor, Japan.

The distinctness of this species has been much disputed. P. Fischen ${ }^{1}$ and A. H. CоOKE ${ }^{2}$ mention it as synonymous with A. Arabica, Forsk. (Phil.); Konelt ${ }^{\text {* }}$ believes it to be synonymous with A. maculata, Sow.; EDG. A. SMrth and E. LAMY consider it to be identical with A. imbricata, Brug. (= umbonata, Lam., cuneata (cunealis), Reeve and Americana d'Orb.). G. B. SowErвy id identifies it with A. mutabilis, Sow. Lamy in his latest revision of the species of Arca (Journ. de Conchyl., vol. 55, 1907, p. 28) identifies, and without doubt correctly, A. Kraussi, Phil. with A. imbricata, Brug. var, arabica Phil.

The specimens from the Gulf of Siam agree closely with the description and figures of Kinauss and lHirpr. Area bicarinata, G. B. Sowerby ${ }^{\top}$ from Cebu (Philippines) is, no doubt, simply the present species.

\section{Arca signata, Dunk.}

(1'. 1, Figs. 14-15).

Arca signata, Dunkek, Novilales conchologicac, $1858-70,13.112$, pl. 38, figs, $3-5$.

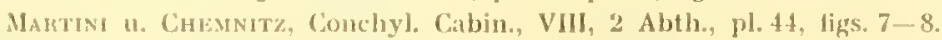

- (Barbalia) signala, I) unkil, L.MY, Journ. de Conchyl, vol. 55, 1907, p. 78, pl.1, figs. 1-2.

1 Journ. de Conchyl., vol. XIX, 1871, 1. 213.

"Annals and Magaz. of Nat. Hist., 5. ser., vol. 18, 1886, p. 92.

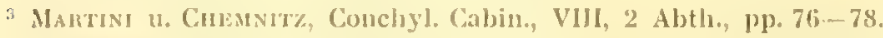

1 Challenger Expedition. Report on the Lamellibranchiata, p. 259. - Heport on the zool. collect.

made during the voyage of "Alert." p. 110. - I'roc. Zool. Soc. London, 1891, p. 431.

s liulletin du Muséum d'llistoire Naturelle, 1904, p. 271.

" Marine sliells of South Africa, 1892, p. 65.

7 Proceed. of the Malacolog. Soc. London, vol. VI, 1901, p. 211, pl. 22, fig. 14. 
The northern side of Koh Mesan, 10-15 fathoms, stones (1). S. of Kolı Chuen, 30 fathoms, shells (2). Between Koh Kut and Koh Kahdat, 10 fathoms, shells (2/2).

Long. 8-23 $\mathrm{mm}$.

Distribution:- King Island, Mergui Archipel (E.v. Martens), Poulo Penang (Mus. Calcutta), Bombay (Mus. Calcutta). - Amoy (Jousseaume).

E. v. Martens ${ }^{1}$ and Lamy refer this species to the subgenus Barbatia. But it appears to me that it should be placed with Arca (s. str.). Dunken has already stated, that the species varies considerably in regard to form, and the specimens from the Gulf of Siam, as well as LAMY's figure, entirely confirm this statement. As the specimen figured by Dunker is rather monstrous I have thought it right to give a new figure of a typical specimen.

\section{Arca (Barbatia) fusca, Brug.}

Area fusca, Brưuì̀re, Dictionn. encycl. méthod., I, 1792, p. 102, No. 10.

Encycl. méthod., pl. 308 , fig. 5 .

Lamarck, Anim. s. vertèbres, ed. 2, VI, p. 466, No. 14

ReEve, Conchol. icon, II, Arca, Sp. 82.

- (Barbatia) fusca, Brug., Martini u. Cuemnitz, Conchyl. Cabin., Vlli, 2 Abtlı., p. 18, pl. 4, fig. 2 ; pl. 6 tigs. $5-6$.

P. Frscher, Catal. d. Moll. de l'Indo-Chine, p. 214.

- _ - _ LaMY, Jouru. de Conchyl., vol. 55, 1907, p. 53.

- bicolorata, Chemnitz, Conchyl. Cabin., XI, 1795, p. 243, pl. 204, fig. 2007.

The northern side of Koh Chang, 1 fathom, coral blocks (21/2). Koh Mak, sand coast ( $1 / 2)$. Koh Kahdat, 1 fathom, sand (1).

Long. $12-33 \mathrm{~mm}$.

Distribution:- Singapore (The Danish Expedit. to Siam, 2 specimens, 2-3 fathoms, coral-reef), Mergui Isls., Nicobar Isls., Madras, Gulf of Manar, Red Sea, Seychelles, Madagascar, Mascarenes, Querimba Isls. - Poulo-Condor, Cochin China, Philippines, Mentawei Isls., Celebes, Sulu IsIs., Java, Small Sunda Isls., Moluceas, Aru Isl., Sorong, 'Torres Strait, North, East and West Australia, Salomo Isls., Viti Isls., Tonga IsIs., Lifu Isl., New Caledonia, New Zealand.

LAMY (loc. cil. p. 53) considers A. cruciuta, Philippi and A. Rodatzi, Dunker (from Zanzibar) to be synonymous with $A$. fusca, Brug.

\section{Arca (Barbatia) complanata, Ch.}

(Pl. 1, Figs. 5-10).

Arca complanata, Chrmsitz, Conchyl. Cabin., Vll, 1784, p. 198, pl.55, figs. 544-45.

-. - _ _ L. Morlet, Journ. de Conchyl., vol. 37, 1889, p. 162.

- (Barbatia) complanata, Chemnity, P. Fischer, Catal. d. Moll. de l'Indo-Chine, p. 215.

Byssoarea decussata, Sowenny, Proc. Zool. Soc. London, vol. I, 1833, p. 18.

Area - - ReEvE, Conchol. icon., II, Arca, Sp.81.

3 The Journal of the Linnean Soc., vol. XXI, 1887, p. 207. 
Alea (Barbalia) decussala, Soweris, Martini u. Chemnitz, Conchyl. Cabin, VIII, 2 Abth.. p. 144, pl. 37. figs. $2-5$.

E. LaMY, 13ull. du Mus, d'Hist. Nat. Paris, 1904, p. 273. - Loc. cit. 1906, p. 317, No. 78 .

B!jssoarca velala, Sowerby, Proc. Zool. Soc. London, vol. J, 1833, p. 18.

Arca - - - ReEve, Conchol. icon., II, Arca, Sp. 79.

Barbatia - - var., Duskeß, Novitates conchologicae, p. 124, pl. 41.

Arcu (Barbatia) veluta, Sowerby, Mantini u. Chemnitz, Conchyl. Cabin., VIll, 2 Abtl.. p. 207, pl. 49. ligs. $2-3$.

The north side of Koh Mesan, 10-15 fathoms, stones (1). Koh Chick, rocky coast (3). North end of Koh Chang, 1 fathom, old coral blocks (38). 'The same locality, 12 fathoms, old coral blocks (4). West coast of Koh Chang, 10 fathoms, mud (5). Koln Sarlak (2). Lem Ngob, on piles of bridge, very low lide (2). Koh Lom (3). Strand of Koh Kahdat (1). Koh Mak, sand coast $(1+\% / 2)$.

"Sinum Siamensem habitare dicitur" (Barbatia velata, Sow, var., Dunker). Islands in the Gulf of Siam (A. complanata Ch., L. Morlet, loc. cit.).

Long. 8-55 $\mathrm{nmm}$.

Distribution: - Singapore, ${ }^{1}$ Salanga, Mergui Archipel, Nicobar Isls., Madras, Ceylon, Persian Gull, Gull of Aden, Red Sea, Gull of Suez and Akaba, Seychelles, Madagascar, Mascarenes. - Poulo Condor, China, Japan, Philippines, Celebes, Torres Strait, New Caledonia, Viti Isls., Funafuti (Ellice Isl.), Paumotu Isl., Society Isls., New Zealand, Galapagos Isls. (San Thomé in the Gulf of Guinea, Hoyle?).

On the hasis of the material at hand, I have united Arca decussata, Sow. with A. velata, Sow. into one species, as it is not possible to keep these forms distinct, $A$. decussata merging by easy stages into $A$. velata, while the specific characlers which have been pointed out, are not constant. In Pl. 1, Figs. 5-10 I have ligured several forms which show this transition better than it could be shown by any description. It was undoubtedly owing only to the lack of a larger quantity of material that SowErny established two species upon specimens taken in the same localities "Lord Hood's and Chain Islands, Pacific Ocean, attached to shells. Cuming"). "The literature gives indications of the great uncertainty which authors show in the determination of the highly variable Barbatia-forms; while a great number ol species:- A. foliata, Forskål, "revelata, Dsh., Petersi, Dkr., sculptilis, Reeve and many others need to be known in more complete development- and variation-series before their distinctness can be guaranteed. The reported occurrences of the West-Indian species Arca Heblingi, Ch. (candida, Gmel.) in Asiatic waters are without doubt due to erroneous determinations, and all the specimens in question should evidently be referred to A. complanala; nor is A. nivea, Ch. sufficiently defined as a species, and it needs revision. ${ }^{4}$ PAgenstecher however, goes too far, ${ }^{\prime}$ when

Taken by the Danish Lxpedition to Siam, four specimens, in 2--3 fathoms, coral-reef.

In spite of Cummnty's naming Guinea as the home of his species A. complanala, an undoubtedly incorrect statement, I have not hesitated in referring the forms we are here considering to that species.

3 v. MarTins, Vorderasiat. Conchylien 1874, p. 103, pl. 9), fig. 58.

Eis. Iamy, Journ. de Conchyl., vol. 52, 1904, p. 140. - Bullet. du Mus. d'Hist. Natur., 1904, p. 272. leber die von M. lossman am Kothen Meere gesamm. Mollusken. L,pzg. 1877, p. 35. 
he refers Arca lactea var. erythraea, Issel, from the Red Sea to A. decussata, Recve (Sow.), as stated by A. H. Cooke, ${ }^{1}$ it is in reality only a form of A. lactea L. LAMY in his latest revision of the gen. Arca regards A. complanata, Ch., somewhat differently from the way in which I regard it here. He gives $A$. velata, Sow., as a variety of $\mathrm{A}$. complanala, Ch. (which he names $\mathrm{A}$. nivea, Ch.), and places $\mathrm{A}$. decussata as a distinct species; but as LAMY's work was not published until I had finished my work upon the Arca-group, I have not been able to consider it here.

\section{Arca (Barbatia) lima, Reeve.}

Arca lima, ReFve, Proc. Zool. Soc. Lond., XII, 1844, 13. 125.

- - C Conchol. icon., II. Sp. 101

- (Barbalia) lima, Reeve, Martivi u. Chrmn., Conchyl. Cabin., VIII, 2 Abth., p. 115, pl. 30, ligs. 5 - 6) LDG. A. SMTr, Lamellibranchiata of the Challenger Exped., p. 260.

Report on the zoolog. collect. made during the voyage of H. M. S. "Alert," p. 110.

E. LAMY, Bull. du Mus. d'Hist. Nat. Paris, 1904, p. 273.

- decussala, Soweliby var, lima, IRekve, Lamy, Journ. de Conchyl., vol. 55, 1907, p. 65.

Koh Kram, 6-10 and 30 fathoms (3). E. of Koh Chuen, 9-10 fathoms, shells (2). Koh Chuen, 10-15 fathoms (2). S. of Koh Chuen, 30 fathoms, shells (3/3). Ot1 Koh Kam, 10 fathoms, gravel (1). Gulf of Rayong, sand, mud and shells (1). North and west coast of Kioh Chang, 1 fathom, old coral blocks (12). Koh Kahdat, 1 fathom, sand (2). W. of Koh Kut, 30 fathoms, sand and mud (1/2). Between Koh

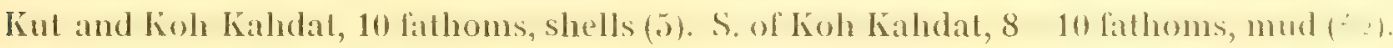
Long. 3-45 $\mathrm{mm}$.

Distribution:- Singapore (low water, Sv. Gad), Madras, Gulf of Manaar, Laccadive and Maldive Archipel., Gulf of Aden, Red Sea (pleistocene). - Philippines, Torres Str., Port Molle, St. Vincent's Gulf, South Australia, South. I’amuotu Isls.

The following species may safely be reckoned as synonymous with Arce lima, Reeve: - Barbatia oblonga, Dkr. ${ }^{3}$ (non Anomalocardia oblonga, Phil. et Dkr.), Arca granulata, Phil., from the Sandwich Islands, Barbatia (Acar) aceróa, Melv. \& Stand." EDG. A. Smin" states that A.trapezina, Lam. ("as determined by ReFve"), is probably" a form of A. lima, Reeve; how far trapezina, Lam., is on the whole a form of A. lima I am not at present prepared to say; that the whole Barbatia-group when, later, a larger quantity of material is at hand and further comparalive investigations have been carried out - will unquestionably be reduced in many respects, is practicaliy certain. In many cases it is very difficult to determine young specimens of A. lima and to keep them distinct, as for example from A. complanala,

1 Annals and Magazine of Nat. I1ist., 5. ser., vol. 18, 1886, p.93.

Journ. de Conchyliologie, vol. 55, 1907, p. 59.

${ }^{3}$ Novitates Conchologicae, p. 107 and p. 85.

"Abbild. und Beschreib. neuer od. wenig gekannt. Conclayl., II, p. 114 (22), pl. VI, figr. 3

'Journ. Linn. Soc. Zoology, vol. XxvII, p. 186, pl. 10, fig. 15.

"Proc. Zool. Soc. London, 1891, p. 431. 
Ch. I cannot agree wilh EDG. SMitu when he says" that "The few ribs towards the middle being duplicate, as stated by REEvE, is an individual rather than a specific character;" in all the specimens from the Gulf of Siam the majority of the ribs in the middle towards the hinder extremity are duplicate. As mentioned in connection with $A$. complanata, Ch., I have unfortunately not been able to take into full consideration LaMY's work on the genus Arca, as my investigations upon this genus were ended when the work in question was published.

\section{Arca (Barbatia) parva, Sow.}

Byssoarca parna, Sowerny, Proc. Zool. Soc. London, 1833, p. 19.

Arer - - REeve, Conchol. icon., J, Arca, Sp. 119.

- (Barbalia) parva, l3erve, Martixi u. Chemsitz, Conchyl. Cabin., VIII, 2 Albth., p. 197, pl. 47, fig. 7. Sowerby, Lamy, Journ. de Conchyl., vol. 55, 1907, p. 51.

Barbalia altenuata, Dunken i. 1. Museum Godeffroy. Catalog IV, 1869, p. 114 - Catalog V, 1874, p. 173.

West coast of Kol Chang, 10 fathoms, mud (1). Koh Mak, sand coast (1/2). Long. 15-21 $\mathrm{mm}$.

Distribution: - Persian Gulf, Djibouti, Gulf of Suez, Madagascar. - Tahiti, Paumotu Isl, Ducie's Isl.

\section{Arca (Barbatia) Siamensis, n. sp.}

(Pl. 1, Figs. 16-17).

This shell is rather thin and ventricose, oblong rectangular in outline, and the posterior half is swollen from the umbones obliquely downwards towards the posterior part of the ventral side. The valves are somewhat obliquely twisted, and the left valve projects, having its lower edge below that of the right valve. The anterior end is rounded and passes evenly into the ventral side; the posterior end, which is much higher, is rather straightly truncate and slopes obliquely downwards towards the ventral side, with which it makes a rounded angle; the ventral side is somewhat compressed in the middle. The surface of the valves is closely set with about 48 flattened, smooth, radiating ribs, which are provided with a longitudinal furrow towards the anterior end. The interstices between the ribs are narrower than the ribs. From the umbones and down to the middle of the ventral side there is a depression of the valves. The upper margin is straight and rises sharply towards the posterior end. The umbones are siluated in the anterior third of the shell. The area is very narrow and long. The colour is white and the hinder margin of each valve is dark-coloured. 'The surface is covered by a thin, brown epidermis which in the inferstices between the ribs is set with small scales or bristles. There are about 47 hinge-tecth. The interior of the valves is white, and the outer ribs project beyond the margin so that the latter becomes dentate.

IReport on the zoolog. collections made during the voyage of H. M. S. "Alert," p. 110. 
Long. $24 \mathrm{~mm}$., alt. $14 \mathrm{~mm}$., crass. $10 \mathrm{~mm}$.

Between Koh Rin and Cliff Rock, 15 fathoms (1/2). Koh Kram, 30 fathoms (1/2). Gulf of Koh Chang, 3-5 fathoms, soft clay (2/3). Between Koh Kut and Koh Kahdat, 10 fathoms, shells $(5 / 2)$.

This characteristic species is nearest related to A. obliquata, Gray, and $A$. decussata, Lischke, but may easily be distinguished from these forms.

\section{Arca (Fossularca) pectunculiformis, Dunk.}

Barbatia pectunculiformis, DunkER, Novitates conchologicae, 1866, p. 88, pl. 28, figs.4-6.

Arca (Barbalia) pectunculiformis, Dunker, Martini u. Chemnitz, Conchyl. Cabin., VIII, 22 Abth., p. 125.

- (Noetia) - - LAMY, Journ. de Conchyl., vol. 55, 1907, p. 300.

W. of Koh Chuen, soft clay and mud (13/2). S. of Koh Samit, 20 fathoms, mud ( $\left.{ }^{4} / 2\right)$. Gulf of Koh Chang, 5 fathoms, soft clay $\left({ }^{4} / 2\right)$. Strand of Koh Kahdat $\left({ }^{15 / 2)}\right.$. S, of Koh Kahdat, 8-10 fathoms, mud (2/2). Between Koh Kahdat and Koh Kut, 6 fathoms, clay mixed with sand (18/2). S. of Koh Kut, 17-20 fathoms, mud (1/2). W. of Koh Kut, 15 fathoms, mud (1/2). W. of Koh Kong (1).

Long. 3-10 1011 .

Distribution:- Karikal (Coromandel Coast, subfossil, Dautzenberg), Borneo (Dunker), Surahaja (Java, ED. v. Martens).

Arca olivacea, Reeve, is very closely related to this species. Can some of the recorded occurrences of A. lactea L. in Asiatic and Australian waters, be due to erroneous determination of A. pectunculiformis, Dunk.?

\section{Arca (Fossularca) sculptilis, Reeve.}

Arce sculplilis, RrEvE, P'oc. Zool. Soc. London, 1844, p. 128, - Conchol. icon., II, 1844, Arca, Sp. 118.

- (Barbatia) sculptilis, Rerve, Evg. Smitu. Rep. Lamellibranchiata of the Cilnallenger Exped., p.262.

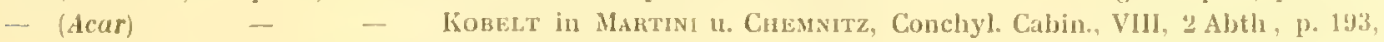
No. 175 , pl. 46 , fig. 14 .

Common between Koh Lan and Koh Mak, many specimens in 1-38 falhoms, sand, mud, gravel and shells.

Long. 2-13 $\mathrm{mm}$.

Distribution:- Bombay (Melrile et Abercromire, A. Zchuensis, Reeve), Karachi (Melvill d Standen). - Amboina (Challenger), Philippines (Rleve), Torres Strait. (Melvill it Standen).

LAMY (Journ. de Conchyl., vol. 55, 1907, p. 100) identifies A. sculptilis, ReEve, with A. afra, Gmel. var. solida, Sow. I do not think that he is correct in so doing. Apart from other considerations the differing geographical distributions of A. afra, Gmel. (= A. pisolina, Lam.), A. solida, Sow., and A. sculptilis, Reeve, are at once conspicuous; besides, it seems to me that A. sculptilis may very well be

1 As communicated by letter. 
separated from the two other forms mentioned above, at any rate as far as the specimens from the Gulf of Siam are concerned. These agree entirely with the diagnosis and figure by ReEve, and also with the excellent description by Eugar Smitr of A. sculptilis. 'They do not at all resemble the figure of LAMARCK's original specimen of A. pisolina (in Journal de Conchyl., vol.52, 1904, pl. 5, figs. 6-7); neither do they agree with REEvE's diagnosis and figure of his species $A$. solida. The great number of specimens which I have before me all show a white colour under the thin epidermis. A. Zebuensis, Reeve, is undoubtedly synonymous with A. sculplitis.

\section{Arca (Fossularca) tenebrica, Reeve.}

Arce t'nebrich, RiEv1:, Proc. Zool. Soc. London, XII, 1844, p. 126.

- - - Conchol. icon., II, Arca, Sp. 105.

- (Barbalia) tenebrica, Rreve, Martins u. Chemnitz, Conchyl. Cabin., VIII, 2 Abth., p. 156, pl. 39, figs. $7-8$.

- - - - - Eng. A. Sмiтн, Report on the zoolog. collect, made during the voyage

(Fossularca) of H. M.S. "Alert," 1884 , p. 110.

Coast of Lem Ngob) (1). North end of Koh Chang, 1 lathom, old coral blocks (4). Koh Chang, between stones at very low tide (46). Gulf at the south end of Koh Chang (1). Strand of Koh Kahdat (1/2).

Long. $7-16 \mathrm{~mm}$.

Distribution: - Bombay, Karachi (Mervel \& Standen). - Philippines, Japan (Nagasaki), Port Essinglon, Port Curtis.

The epidermis is extremely velvel-like in several of the specimens from the Gulf of Sian, and the outline in this species varies rather considerably.

\section{Arca (Acar) plicata, Ch.}

Area plicula, Chnmsitz, Conchyl. Cabin., XI, 1795, p. 244, pl. 204, ligs. 2008.

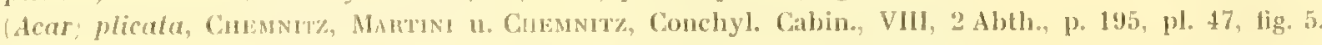
L. LAsY, lBull. du Mus. d'Hist. Nat. P'aris, 1904, pp. 274-75.

Journ, de Conchyl., vol. 55, 1907, p. S0. - Bull. du Mus. d'llist. Nat. Laris, $1906,13.317$.

squamosa, LAMAncK, Anim. sans vert., VI, part. 1, 1819, p. 45, No. 35. - éd. 2, VI, p. 474, No. 35.

- - Sivigx, Deser. de l'Égypte. Mollusques, pl. 10, fig. 6.

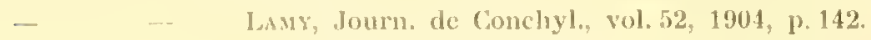

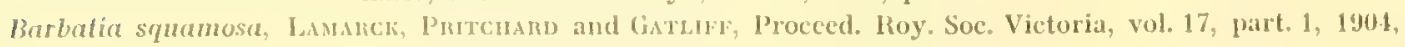
1). 241.

Area Domingensis, ‥ Anim. sans vert., VI, part. 1, 1819, p.40, No. 16. - éd. 2, VI, p. 467, No. 16. Anischist, Japan. Meeres-Conchyl., 11, p. 142 u. III, p. 107.

- (Acar) domingensis, Jamanck, Lin. A. SmTn, Lamellibranchiata of the Challenger Exped., p. 265.

- gradalu, 13нonsmip and SowsmuY, Zoolog. Journal, IV, 1829, p. 365.

Gray, Zool. of Beechey's Voyage, p. 152, pl. 43, tig. 1.

HaNLEY, Rec. biv. shells, p. 155, pl. 18, fig. 39.

Rrieve, Conchol. icon., II, Arca, Sp. 92.

Byssoarea divaricala, Sownur, l'roc. Zool. Soc. London, I, 1833, p. 18. 
Byssoarca pusilla, Sowentiv, Proc. Zool. Soc, I, 1833, p. 18.

Arca - - ReEve, Conchol. icon,, II, Arca, Sp. 112.

- donaciformis, ReEVE, Conchol. icon., II, Arca, Sp. 104.

- (Byssoarca) pholadiformis, C. 13. Adams, Shells coll. at Panama, 1852, 1). 260.

Barbatia (Acar) laminata, Angas, Proc. Zool. Soc., 1865, pp. 697 and 655.

Arca (Byssoarca) dubia, BaInd, BRExchley, Jottings during the cruise of H. M. S. Curaçoa among the South Sea Islands, 1873 , p. 453 , pl. 42, figs. 5-6.

- M' Coyi, Tenison-IVoods, Transact. and Proc. Roy. Soc. Victoria, vol. XIV. 1878, p. 61.

Gulf of Siam $(1 / 2)$.

Long. $15 \mathrm{~mm}$.

Distribution: - Gulf of Manaar, Mangalore (Malabar Coast), Maldive Archip., Arabian Sea, Gulf of Oman, Persian Gulf, Gulf of Aden, lhed Sea, Gulf of Suez, Mozambique, Natal coast, Seychelles, Amirantes, Madagascar, Mauritius, Cape of Good Hope, St. Helena, Ascension, Annobon, St. Thomé, Cape Verd Isls., Madeira. Tonkin, South Japan, Philippines, Moluccas, Torres Strait, North, East and South Australia, Tasmania, the South Sea Islands, New Caledonia. - West coast of America from St. Barbara to Peru; East coast of America: Bermudas, Florida, Gulf of Mexico, Bahamas, Greater and Lesser Antilles.

The wide distribution of this species, together with its great tendency to variation, has caused it to have numerous names given to it in the course of lime. Lischise, ${ }^{1}$ and more recently ED. LAMY, ${ }^{3}$ have recorded a great many of these. A. H. COOKE ${ }^{3}$ doubts the correctness of Lischre's views upon the identity of these species; he is of opinion that they are three well-distinguished forms: gradata (the West American form), Domingensis + squamosa (the West Indian form), divaricata, Sow. = plicata, Ch. (the East Indian form); but the distinguishing characters recorded by him are not valid. I have at my disposal a fairly large quantity of material of A.Domingensis from the West Indies, and the extensive variation-series includes, as far as I can sce, all the forms which have been established. I think, W. H. DALL is mistaken when he refers A. Domingensis, Lam., and gradata, Brod. \& Sow., from the Gull of Mexico and the Caribbean Sea to A. reticulata, Ch. He supposes that A. congenita, Edg. A. Smith, also, is possibly only a form of A.plicata, Ch.

Arca (Acar) tenella, Reeve.

(P1. 1, Figs. 11-13).

Arca tenella, ReEvli, Proc. Zool. Soc. London, Xill, 1844, p. 124.

- - - Conchol. icon., 11, 1844, Arca, Sp. 91.

- (Barbatia) tenella, Reeve, Mantini u. Cinemnitz, Conchyl. Cabill., VIII, 2 Alth., p, 155, pl. 39, figs. 5 - 6. Barbatia mollis, DUNkER, Novitates concholog., 1867, p.92, pl. 31, figs. 2-4.

Arca (Burbatia) mollis, Dunker, Mantri u. Chemnitz, Conchyl. Cabin., VIII, 2 Abtlı., p. 128, pl. 33 , figs, 5 -6.

- Acar) tenella, Reeve, Lamr, Journ. de Conchyl., vol.55, 1907, 1).93.

1 Japanische Meeres-Conchylien, II, p, 142, III, p. 107.

2 Journal de Conchyliologie, vol.52, 1904, pp. 142-47, and vol. 55, 1907, pp. $80-87$.

3 Annals and Magazine of Nat. Hist., 5. Ser, vol. 18, 1886, p.91.

" Report of the Mollusca of the "IBlake" Expedition, 1, 1886, p. 242. 
Kolı Lan, 30 fathoms, mud (1/2).

Long. $19 \mathrm{~mm}$.

Distribution:- Laccadive and Maldive Archip., Djibouti (LAMy), Isle of Bourbon (Deshayes), Madagascar. - Philippines, Torres Strait, Viti Isls., Funafuti (Ellice Isls.), Samoa Isls.

In the specimen from the Gulf of Siam the ribs are not markedly granulated. Prof. ED. V. MARTENs, whom I asked to compare the specimen with Dunken's original specimen, informed me that it "stimmt ganz gut zu den Original Exemplaren von A. mollis, Dunk."

Arca (Anadara) granosa, L.

Arca granosa, Linni, Syst. Nat., ed. X, 1758, p. 694, No. 146. - ed. Xil, p. 1142, No. 176. - ed. XIII, p. 3310 , No. 18. - Mus. Ludov. Ulr., p. 519, No.93.

- - - Cilinnitz, Conchyl. Cabin., VII, p. 219, pl.56, fig. 557.

- - - REeve, Conchol. icon., II, Arca, sp. 15.

- (Anomalocardia) granosa, Linné, Mantini u. Ciemnitz, Conchyl. Cabin., VIII, 2 Abth., p. 38, pl. 3, fig. 7.

- (Anadara) - LaMalick, Morlet, Journ. de Conchyl., vol. 37, 1889, p. 162.

- granosa, LinnF́, ED. LAMY, Journ. de Conchyl, vol.52, 1904, p. 158. - loc. cit., vol. 55, 1907, p. 210.

- Anomalucurdia) granosa, L. Dautzexieng ef Fisciler, Journ. de Conchyl., vol. 53, 1905, p. 193.

Coast of Lem Ngol) (1). Coast of Koh Chang ( $8 / 2)$. Isles of the Gulf of Siam (L. MORLET).

Long. $27-47 \mathrm{~mm}$.

Distribution: - Malacca, Mergui Archip., Bassein river (Burma), Nicobars, Madras, Tranquebar, Gulf of Manaar, Bombay, - Cochin China, 'Tonkin, China, Japan (Nagasaki, Kod\%uka), Philippines, Sumalra, Java, Borneo, Celebes, Moluccas (Lucipara, Ceram, elc.), Timor, Macassar, Aru Isl., Sorong.

According to E. v. MARTENS ${ }^{1}$ this species occurs frequently in brackish water at Singapore, on Borneo, Celebes, Sunda Islands and other places. M. v. Niumariz slates" that an "Arca granulosa L. var. minuta" was found among fresh-water shells ("und zwar mit Arten der Gattungen Vivipara, Bythinia, Melania und Corbicula") in the deposits of the Yang-tse-kiang delta. 'This is nearly certainly a form of A. granosa which lives here in brackish water under conditions similar to those prevailing in the localities ${ }^{3}$ stated by v. MArTEns.

\section{Arca (Anadara) oblonga, Phil.}

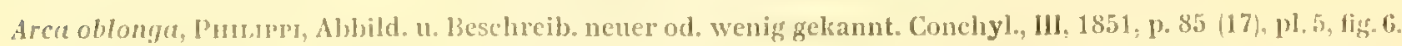

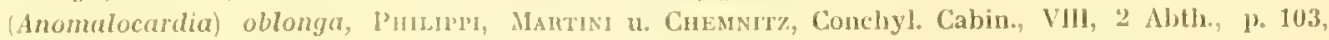
pl. 27 , tigs. $7-8$.

- (Analara) - - P. Fischiln, Catal. d. Moll. de l'Indo Chine, 13.215.

1 Zoolog. Ergehnisse einer Reise in Niederländ. Ost-Indien hrsg. v. M. Weber, IV, 1897, p. 228.

2Wissenschaftl. Ergebnisse d. Reise d. Grafen Bçla Szćchenyi in Ostasien, 1877 - 80, 11, 1898, p. 641, pl. 1, lig. 4 .

3 compare also alout its occurrence in the Basscin river, in Journ. of the Asiatic Society of Bengal, vol. 36,1867, ,. 70 . 
Coast of Koh Chick (1/2). Sound of Koh Chang, 3-5 fathoms, soft clay, very common, taken in great numbers. Coast of Lem Ngob (1/2). Between Kol Kut and Koh Kahdat, 10 fathoms, shells (*/2).

Bangkok (Siam) Coll. Dautzenberg (P. Fischer loc. cit.).

Long. 2-27 $\mathrm{mm}$.

Distribution:-- Salanga, on the west coast of Malacca (v. Martens). Mergui Archip. (Pinlippr).

It seems to me that there is a very close conformity and even transition, between the forms representing the series:- oblonga, Phil. - oblonga, Dunker ${ }^{1}$ nodifera, Martens ${ }^{2}$ - paucigranosa, Dunker. ${ }^{3}$ I feel practically certain that all these forms should be referred to one species. Anomalocardia pulchella, Dunker, ${ }^{4}$ is, no doubt, simply the present species. Prillppr's statement" that "Die Area ist ganz vom schwarzen Ligament eingenommen" has, in Kobelt's diagnosis (MARTin u. Chemnitz, loc. cit.), been altered to "das schwarze glatte rautenförmige Band lässt vornen und hinten ziemlich viel Raum frei"' this agrees also with the specimens from the Gulf of Siam. ED. LAMY ${ }^{6}$ considers A. oblonga, Phil., to be a form of A. granosa L.

\section{Arca (Anadara) subrubra, Dunk.}

Anomalocarlia subrubra, Dunken, Novitates conchologicre, 1866, p. 83, No. 92, pl. 28, ligs. 1-3.

Arca (Anomalocardia) subrubra, Dunker, Kobelt in Maktini u. Chemnitz, Conchyl. Cabin., Vili, 2 Albh., P. 111, No. 83, pl. 29, figs. 4-5.

- (Anadara) antiquata L. var. subrubra, Dunker, LAMY, Journ. de Conchyl., vol. 55, 1907, p. 200.

Koh Chuen, 30 fathoms $(2 / 3)$.

Long. 13-15 $\mathrm{mm}$.

Distribution:- Philippines.

1 Novitates conchologica, p. 85, pl. 29, figs. 7 -9. recorded to have been taken at the Mergui Islands.

2 Proc. Zool. Soc. London, part 28, 1860, p. 17. Maktini u. Chemnitz, Conchyl. Cabin., VIII, 2 Abth., p. 46, pl. 13, figss. 3-4. Recorded from Bangkok and Java by E. v. Mantins who ("Zool. Ergelonisse ein. Reise in Nicderländ. Ost-Indien lurs. v. M. Weber," 1897, p. "28) states that it is sold as food in Bangkok, and that it lives in brackish water in these localities. It is a misprint when v. Mantens (loc. cit.) states, that $A$. nodifera is "17 mal so lang als hocls."

${ }^{3}$ Novitates conchologica, p. 85, pl. 29, figs, 10-12. Mantini u. Cihennitz, Conchyl. Cabin., VIII, 2 Abth., p. 100 , pl. 27, figs. 1-2. KoвELT is also of opinion (in the last-mentioned work) that A. pancigranosa, Dunker is only a more feebly sculptured example of A. nodifera. Duskn records it from "Siam."

* Novitates conchologicae, p. 113, pl. 38, figs. 6-9. Dunier records it from "Japan." IR. STEARNS from the east coast of Nippon. As ReEve had already in 1814 employed the same specific name for an Arca (Acar) from the Mediterranean, Dunkris's name must certainly be altered. (For the reasons which justify the adoption of Reeve's name A. pulchella, for the Mediterranean species instead of $A$. imbricata, Poli, see "Bucquoy, Dautzenberg et Dollfuss, Les Mollusques mar. du Roussillon," If. 1). 190).

Abbild. u. Beschreib. neuer od. wenig gekannt. Conchyl. (Ioc. cit.).

t) Journ. de Conchyl., vol. 52, 1901, p. 160, and vol.55, 1907, p. 210. 
Arca (Anadara) uropygomelana, Bory.

Area uropigimelana, BonT DE Sr VINCENT, Encyclopédie métlod., 1797, pl.307, fig. 2..

(Anomalocardia) uropygmelana, Bony, Mantini u. Chemnitz, Conchyl. Cabin., VIJ, 2 Abth., p. 85. pl. 23 , figs. $5-6$.

- (Anadara) uropygmelana, Bory de Saint-Vincent, LaMy, Bull. du Mus. d'Hist. Nat. 1'aris, 1904, J. 277.

- Journ. de Conchyl., vol. 55, 1907, 1. 207.

- holoserica, ReEvi, Proc. Zool. Soc. London, XII, 1844, p. 39.

- - - Conchol, icon., II, Area, Sp. 11.

- - - Monlet, Journ. de Conchyl., vol. 37, 1889, p. 162.

(Anadara) holosericea, ReEve, P. Fischir, Catal. de Moll. de lindo-Chine, p. 216

- - holoserica, - EDG. SMrTr, Proc. Zool. Soc. London, 1891, p. 431.

MonLet (loc. cit.) states that the present species (A. holoserica, Reeve) is taken at "Isles du golfe de Siam." LAMY, however, points out (Journ. de Conchyl, vol. 55,1907, p. 242) that this statement is due to erroneous determination by Mortet, and that the specimens belong to Arca cornea, Reeve var. Cecillei (Phil.), Lamy (compare this species). Nor did the Danish Expedition to Siam collect any specimens of A. uropygomelana, Bory (= A. holoserica, Reeve).

Distribution:- Salanga (Malacca), Felidu Atoll and Hulule Isl. (Maldive Archip.), Gulf of Aden, Red Sea, Mauritius, Madagascar, Seychelles, East Africa, Querimba Isls. - Philippines, Java, Togean Isls., Moluccas, Gilbert Isls. (Kingsmill), New Caledonia.

Sturany ${ }^{1}$ states that a specimen (of A. scapha, Chemn.) resembling A. holoserica, Reeve, has been taken at Ras Abu Somer (Red Sea). W. J. HALL and R. Standen state" that A. uropygomelana, Bory, has been taken on "a raised coral recf" at l'ort Sudan, near Suakim, on the west coast of the Red Sea. Lastly, Lamy states: that specimens from the Red Sea are in the Paris Museum.

\section{Arca (Anadara) Mortenseni, 1. sp.}

(I). II, Figs. 1-2).

'This shell is oval, thin, and rather ventricose. The front passes evenly and with rounded oulline into the ventral side, while the hinder part is more straighlly truncate, and forms a rounded angle with the ventral part. It is white, and bears about 47 sharp radiating ribs which are closely covered with small, regularly-arranged nodules and scales, crossed by fine, concentric lines of growth which give the surface a beatiful, reticulated appearance. Not all the radiating ribs extend over the umbones, but many unite with an adjacent rib. 'The interstices belween the ribs are generally narower than the ribs, and are finely sculptured. A keel, upon which the radiating ribs are further apart and stouter than are the other ribs, extends from the umbones towards the posterior part of the ventral side. Owing to this keel, the well-raised, prominent umbones become oblique, and are higher towards the hinder part. 'The umbones are situated at about the middle of the shell, a trifle nearer its anterior end. The ligament-area is small and narrow. There are about 25-26 hinge-teeth, divergent on cach side of the centre. 'The interior is white; the exterior ribs are there slightly noticeable, and

1 Lamellibranchiaten d. Rothen Meeres, 1899, j).36.

Journal of Conchology, vol. 12, 1907, p. 68.

' Joc, cit., Journ. de conchyl, 1907, p. 209. 
they are deeper only at the place where the keel is situated exteriorly; the margin is crenulated.

Long. $12 \mathrm{~mm}$., alt. $9 \mathrm{~mm}$.

West of Koh Kut, 30 fathoms, sand and mud.

This pretty little, characteristic species, of which unfortunately only a single left valve is at hand, has certainly been provided with an epidermis, but no trace of it is visible. I have taken the pleasure of associating with this new species the name of Dr. Th. Mortensen, who, during the Danish Expedilion to Siam, mado such excellent collections of Molluses, in a place of which the fauna lard been, hitherto, but slightly known.

Arca (Anadara) cornea, Reeve var. Cecillei (Phil.), Lamy.

Arcu (Scapharca) Cecillei (Phippi), Kohelt in Martivi u. Chemvitz, Conchyl. Cahin., Vili, 2 Abth., p. 105, pl. 28 , figs. $3-4$ (non pl. 40 , figs. $2-3$ ).

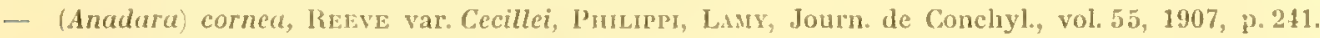

'The Gulf of Siam (PAvie, 1885).

The Danish Expedition to Siam collected no specimens of this species.

Distribution:- Philippines.

MORLET (Journ. de Conchyl,, vol. 37, 1889) had identified the specimens collected by PAviE as A. holoserica, Reeve. LAMY (loc. cit.), however, points out thal they were erroneously determined, and that they belong to the present form. For further details reference should be made to LAsx (loc. cit.), whose view of the synonymy I have adopted.

Arca (Anadara) auriculata, Lam.

Arca auticulata, LAmarck, Hist. nat. d. anim. s. vert,, 1819, VI, part. 1, p. 43. - éd. 2, VI, 1835,1 , 472.

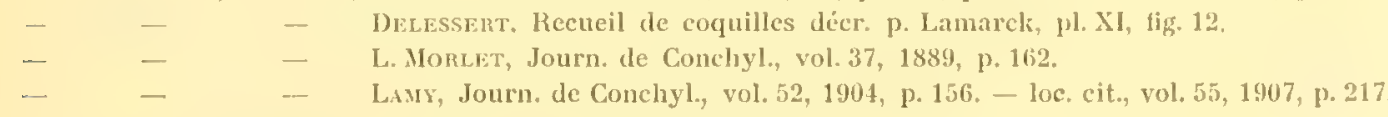

"Iles du golfe de Siam." Morret (loc. cit.).

The Danish Expedition to Siam collected no specimens of this species.

Distribution:- How far the species from the "l'Océan indien," described by LAMARCK, is the same as that which various authors record from the West Indies, I am not prepared to say. SAvignY's figure ${ }^{1}$ of A. auriculata, Lam. (recorded by ISSEL ${ }^{2}$ from the Red Sea), can scarcely be LAMARck's species, which, also, has not since been recorded as found in the Red Sea. Inering ${ }^{3}$ records it from S. Paulo (Brazil), but this seems very improbable, and I venture to suggest that it is due to erroneous determination.

' Déscription de l'Égypte. Coquilles, pl. 10, fig. 8.

* Malacologia del Mar Rosso, 1869, p. 88.

${ }^{3}$ Journ, de Conchyl., vol. 43, 1895, p. 213. 


\section{Arca (Scapharca) globosa, Reeve.}

Arca globosa, REEvE, Proc. Zool. Soc. London, XII, 1814, p. 45.

Conchol. icon., II, Arca, Sp. 52.

- (Anomalocardia) globosa, Reeve, Martivi u. Chemsitz, Conchyl. Cabin., VIII, 2 Ahtlı., p. 203, pl. 48, fig. 4.

- globos $\alpha$, ReEve, Cinosse et Fischer, Journ. de Conchyl., vol. 37, 1889, p. 292.

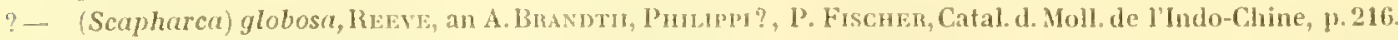

-- globosa, Rever, Lamr, Journ. de Conchyl., vol. 55, 1907, p. 260.

"Siam" (P. Fischer, loc. cit.).

The Danish Expedition to Siam collected no specimens of this species.

Distribution:- Annam, Philippines.

P. Fiscren (loc. cit.) as stated above, doubts the correctness of the determination.

\section{Arca (Scapharca) rhomboidalis, Ch.}

Arca rhomboidalis, Cirmontz, Conchyl. Cabin., VII, 1784, p. 210, pl. 56, fig. 552.

- - _ Nyst, Mém. de l'Acad. roy. d. se. de Belgique, XXII, p.62.

- incequibalvis, Bnuguî̀, Encyclop. méthod, I, 1792, Hist. nat. d. vers., p. 106.

- Lamarck, Anim. sans vert., 2 éd., VI, P. 472, No. 30.

- $\quad$ - $\quad$ Encyclop. méthod., pl. 305, fig. 3 a.

- - - ReEve, Conchol. icon., II, Arca, Sp. 54.

- - Kobelt in Martini u. Chemsitz, Conchyl. Cabin., VIII, 2 Abtlı., p. 40, pl. 3, fig. 1.

- hispida, Prinippi, Abbild. u. Beschreib. neuer od. wenig gekannt. Conchyl., III, p. 86 (18), pl. V, fig. 4.

- disparilis, ReEve, Conchol, icon., II, 1844, Arca, Sp. 59.

- _ _ LAмs, Journ. de Conchyl., vol. 55, 1907, p. 256.

Coast of Lem Ngob (1/2). Sound of Koh Chang, 5 fathoms, soft clay $\left({ }^{1 / 2}\right)$. West coast of Koh Chang, 1 fathom, old coral blocks (1/2). W. of Koh Kut, 30 fathoms, sand and mud (H/2). Between Koh Kut and Koh Kahdat, 6 fathoms, clay mixed with sand $(1 / 2)$. Same locality, 10 fathoms, shells $(9 / 2)$. S. of Koh Bidang, 9 fathoms, mud $(2 / 2)$.

Long. $4-50 \mathrm{~mm}$.

Distribution: - Salanga, Mergui Isls., Madras, the Gulf of Manaar, Panjim and Goa, Bombay, Persian Gulf. - P'hilippines, Moluccas, Borneo, Java, 'T'imor.

LAMY is of opinion that the Arca inaequivalvis of BRUGURere and of REEve is not identical with that species as defined by KoBELT; therefore he places KoBELT'S form as a synonym of $A$. disparilis, Reeve ( $=$ A. rhomboidalis, Chemnitz), while he separates A. inaequivalvis (Bruguière), Reeve, as a distincl species.

\section{Arca (Scapharca) vellicata, Reeve.}

Arca vellicala, IREeve, Proc. Zool. Soc. London, 1844, p.42. - Conchol. icon., 1844, II, Arca, Sp. 33.

- (Seapharca) vellicala, Rexve, Ronelt in Mantini u. Chemntz, Conchyl. Cabin., VIII, 2 Abtlı., p. 177

- Anadara _- _ Lamy, Jouru. de Cochyle, vol. 55, 1907, 1. 251. 
Koh Chuen, 30 fathoms (1). Between Koh Kut and Koh Kahdat, 10 fathoms, shells $\left({ }^{19} / 2\right)$. S. of Koh Kahdat, 8-10 fathoms, mud $(9 / 2)$.

Long. 4--15 $\mathrm{mm}$.

Distribution:- Ceylon (Hanley), Mascat (Brit. Mus.), Red Sea (fossil, Issel). - China (Collect. de l'École d. Mines, Paris).

All the specimens from the Gulf of Siam are small, but correspond well with REEve's diagnosis; the valves are thin; in the specimens without an epidermis there is a distinct intercostal-sculpture between the 46 radiating ribs; the angular transilion, mentioned as occurring between the hinder and lower margins, is more rounded than is shown in REEvE's figure; the characteristic groove upon the umbones is very pronounced in quite small specimens.

\section{Arca (Scapharca) crebricostata, Reeve.}

Area crebricostala, RiEve, Proc. Zool. Soc. London, X11, 1844, p. 46.

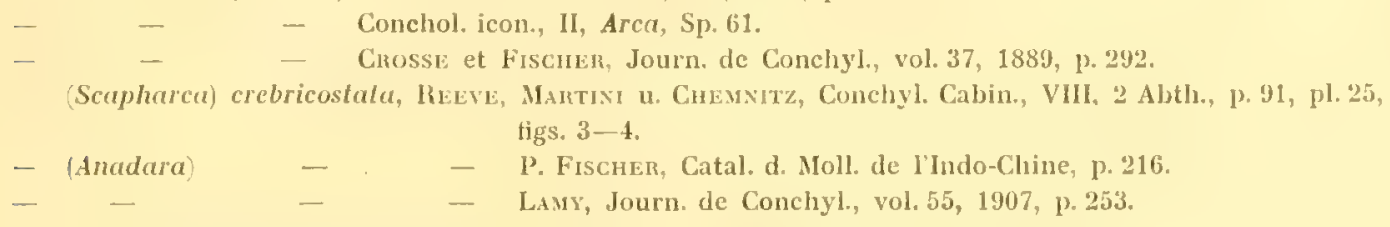

Koh Mak, sand coast (5/3). On the coast of Koh Kahdat (3/2).

Long. 29-49 $\mathrm{mm}$.

Distribution:- Cochin China, Annam.

I cannot make the great number of ribs (43-44), stated by REEvE and KoBELT, agree with the figures given by the same authors, which apparently show only about 35-37. Neither are so many ribs found in the specimens lrom the Gulf of Siam (in which there are only about 35), unless the most anterior, duplicate ribs are to be counted twice.

Arca (Scapharca) clathrata, Reeve.

Arce clathrata, liEEvE, P'roc. Zool. Soc. London, XII, 1844, p. 44.

-. - - Conchol. icon., II, Arcu, Sp. 48.

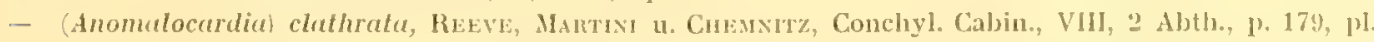

44, fig. 5 .

- Scapharca _ - _ Evg. A. Smrr, Rep. Challenger Lamellibranchiata, p. 26(i,

- (Anadare) - _ LAMY, Bull. du Mus. d'Hist. Nat. Paris, 1904, p. 277.

- _ _ _ Journ, de Concliyl., vol. 55, 1907, p. 229.

Scupharca pygmaca, H. ADaMs, I'roc. Zool. Soc. London, 1872, p. 11, pl. 3, fig. 15.

Arca CookE, Ann. and Mag. of Nat. Hist, 5 Ser., vol. 18, 1886, 1.91.

Common between Koh Lan and Koh Kut, many specimens in 1-30 fathons, mud, sand, clay, and shells.

Long. 3-33 $\mathrm{mm}$.

Distribution:- Madras, Felidu Atoll (Maldive Archip.), Gulf of Oman (Melvill d Standen), Gulf of Aden, Red Sea, Sucz. - Philippines, Amboina, Torres Strait, Mast Head Reef (Queensland). 
In REEve's diagnosis, and in the descriptions of $A$. clathrata given by later aulhors, I do not find any mention of several distinctive characters, peculiar to this species. Thus, in the specimens from the Gulf of Siam, the sculpture is different on the two valves; on the right valve it is only the $8-10$, most anterior ribs which are set with regularly-arranged, small nodules which gradually disappear almost completely from the rest of the ribs; also, on the right valve, all the ribs are somewhat flatter than are those on the left valve. The latter is more strongly sculptured, and on the $18-20$ most anterior ribs the small nodules occur regularly and distinclly, like strings of beads; but they are frequently absent from the most posterior ribs. Upon both the umbones there is a distinct median groove, which occurs in all the specimens, from the smallest to the largest, and which affords a good distinguishing feature by means of which they may be separated from forms nearly related to them. A. H. Cook $\mathbf{E}^{1}$ considers A. rolundicostata, Reeve, to be synonymous with the present species. I believe the same is the case with A. Troscheli, Dunker." EDg. Sutri" doubts ReEve's statement that the epidermis is "very finely bristly between the ribs;" but among the specimens from the Gulf of Siam there are several in which this can be seen, and the bristles in such cases, are particularly strongly developed between the most posterior ribs. Specimens, however, also occur, with a perfectly well preserved epidermis, from which these bristles are entirely absent. As the present species is provided with a byssus, it cannot be referred to the sub-genus Anadara, but must belong, to Scapharca." 'The Siam Expedition brought home several specimens in spirit which show a well-developed byssus.

\section{Arca (Scapharca) consociata, E. Sm.}

Arce (Scupharcus) consociuta, Evo. A. Ssmr, Challenger Exped. Report on the Lamellibranchiata, 1885, p. 266 , pl. 17, fig. 7.

Martini u. Chemertz, Conchyl. Cabin., Vili, 2 Abtlı., p, 221.

- consociata, limx. A. Smru, Ann. and Mag. Nat. Hist, 7 Ser., vol. 14, 1901, p. 12.

W. of Koh Chuen, soft clay (2s/3 young specimens). S. of Koh Samit, 30 fathoms, mud (1/2). Ofl' 'Tung Kaben, 6 fathoms, clay mixed with sand (1/2). Sound of Koh Chang, 4-5 fathoms, soft clay $(3+8 / 2)$. West coast of Koh Chang, 10 falhoms, mud (1). E. of Koh Mak, 20 fathoms, mud (2). Between Koh Kahdat and Koh Kut, 6 fathoms, clay mixed with sand ( $/ 2 / 2)$.

Long. 2-38 mm. (long. 38, alt. 27. - long. 26, alt. 18).

Distribution: - Off Chedubar (Aracan coast, 20-30 fathoms, Smin). Arafura Sea (SMTir).

As may be seen from the measurements given above, Eog. Sumpu is right in believing that his specimen with a length of $125 \mathrm{~mm}$, collected during the Challenger Expedition, is not full-grown.

1 Annals and Magazine of Nat. Hist. 5 Ser., vol. 18, 1886, p. 95.

- Index Molluscor, mar. Japonici, p. 234, pl. 14, tigs. 14-15.

: Proc. Zool. Soc. Lundon, 1891, p. 432.

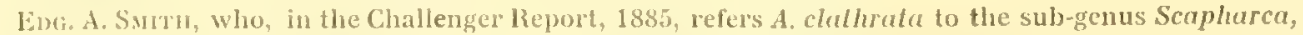
in 1891 (loc. cit. p. 432) had changed his opinion, and placed it under Anculara. 


\section{Arca (Scapharca) dichotoma, Desh.}

(II. II, Fig. 3-4).

Arca dichotoma, Dismays, Conchyl, de l'ile de la Réunion (Bourbon), 1863, p. 22, pl.3, tigs. 18-19.

- (Barbalia?) dicholoma, Deshayes, Martini u. Chemvitz, Conchyl. Cabin., Vil,, 2 Abth., p. 29, pl.s, figs. $7-8$.

W. of Koh Chuen, soft clay and mud (1/2). S. of Koh 'Tulu, 10 fathoms, clay' mixed with sand $\left({ }^{1 / 1}\right)$. Between Koh Kahdat and Koh Kut, 6 fathoms, clay mixed with sand $(1 / 2)$. W. of Koh Kut, 30 fathoms, sand and mud $(1 / 2)$.

Long. $7-17 \mathrm{~mm}$.

Distribution: - Bourbon (DESHAYES).

Professor ED. v. Martens, to whom I sent specimens from Koh Kut, has kindly determined these as $A$. dichotoma, Desh. This species differs, however, in several respects from the specimens from the Gulf of Siam, which have 25 ribs, all of which (except the last two at the anterior end) are divided by a narrow median groove into two ribs of about the same breadth, and covered with regularly-arranged small nodules. As the median groove does not begin quite at the umbo, specimens measuring, for example, about $5 \mathrm{~mm}$. in height scarcely have the ribs at all divided. The interstices between the double ribs are about as broad as the ribs and bear close-set Iransverse lines. The keel, mentioned by Deshayes, which divides the median part from the posterior end, and which, in his specimens bears four undivided ribs, does not occur in the Siam specimens; whether this is owing to individual or specific character, may be known later; at present I shall name the form from the Gulf of Siam, which we are here considering, Arca dicholoma, Desh. var, gratiosa.

\section{Arca (Scapharca) Sabinae, Morl.}

Area (Analare) Sabine, L. Morest, Journ. de Conchyl., vol. 37, 1859, p. 1s9, pl. \&, tig. 6.

\begin{tabular}{|c|c|c|c|}
\hline Scupharca) & - & - & In. de Conchyl., vol. $37,1889,1$ 1. 292. \\
\hline- & - & -- & P. Fiscui:k, Catal. d. Moll. de l'Indo-Cline, p, 216. \\
\hline (Anudura) & - & - & $\begin{array}{l}\text { Mission Pavie Indo Chine, Études diverses, 11, 1904, p. } 378 \text {, pl. 22, } \\
\text { fig. } 6 .\end{array}$ \\
\hline (Cuncurca) & - & - & LAsy, Journ. de Conchyl., vol. 55, 1907, p. 276. \\
\hline
\end{tabular}

Coast of Koh Chick (10/2). W. of Koh Kut, 15 fathoms, mud ( $\left.{ }^{1 / 2}\right)$. Belween Koh Kut and Koh Kahdat, 10 fathoms, shells (1/2). Strand of Koh Kahdat (1/2). Phu Quok in the Gulf of Siam (MorLET).

Long. 9-17 $\mathrm{mm}$.

Distribution:- Ceylon. - Ammam (Cochin China).

'The shells from the Gulf of Siam are rather inequilateral, and not so regularly' formed as that figured by MonLeT; they agree most closely with the description which Crosse \& Fischer give of the individuals from Annam.

Arca (Scapharca) gubernaculum, Reeve.

Arca gubernaculum, Revve, Proc. Zool. Soc. London, XII, 1814, p. 40.

- - C Conehol, icon., II, Arca, Sp. 14.

- - _ Eng. A. S.misu, Lamellibranchiata of the Challenger Exp.. p. 2 (i6. 
Arcu guhernaculum, lkive, Mantivi u. Chemsixz, Conchyl. Cabin., vili, 2 Abth., p. 107, pl. 28, figs. 5-6. P. Fischler, Catal. d. Moll. de l'Indo-Chine, p. $27 \%$.

- Anadari) gubernaculum, ReEvi, Lamy, Journ. de Conchyl., vol, 55, 1907, p. 239.

- chalcanthum, Reeve, Proc. Zool. Soc. London, XII, 1844, p. 44 (fide EDG. SMtTh).

- $\quad$ - $\quad$ - Conchol. icon., II, Arca, Sp. 43.

- Luzonica, Reeve, Proc. Zool. Soc. London, XII, 1844, p. 44 (fide Edg. Smith).

- $\quad$ - $\quad$ Conchol。 icon., II, Arca, S. 44.

"Golfe de Siam," L. Morlet (P. Fischer loc. cit.).

The Danish Expedition collected no specimens of this species in the Gulf of Siam.

Distribution:- Philippines, China, Formosa, Port Jackson.

\section{Arca (Scapharca) indica, Gm.}

(P1. II, Figs. 5-12).

Area indien, Gublix, Syst. Nat., ed. XlII, 1790, p. 3312, No. 27 (excl. var.).

(- - - Lamalick, Anim. sans vert., VI, p. 173, No. 31).

(- - - REEve, Conchol. icon., II, Area, Sp. 56).

- - - Martixi u. Chemsitz, Conchyl. Cabin., vili, 2 Abth., p. 11, pl. 2, fig. 2.

- Argina) indice, Gmilin, Lamy, Journ. de Conchyl., vol. 55, 1907, p. 295.

- Indiue Orientalis, Chesnitz, Conchyl. Cabin., VII, 1784, p. 196, pl. 55, fig. 543.

Ostindische Basturlarche, Mantinı, Beschäftig. d. Berlin. Gesellsch. Naturf. Freunde, III, 1777, pp. 288-90, pl. 6, tig. 13.

Coast of Lem Ngob ( $9 / 2)$.

Long. 21-44 mm., alt. $11-23 \mathrm{~mm}$.

Distribution:- Coromandel Coast (Tranquebar; Chemnitz). Hanley records the species from Sumatra. In the Museum in Berlin are specimens from Sumatra; North-west Australia (MENKE). This species is probably more widely distributed.

By comparison with original specimens of Arca indica, Gm., from Tranquebar, from SPENGLEn's collection in the Zoological Museum of the University of Copenhagen, I have been able to identify the specimens from the Gulf of Siam. The present species has hitherto been badly figured and described. LAmack, REEVE and KOBELT, ${ }^{2}$ all say, that the area is absent in the species; this is not correct (GMELIN also does not mention it). Normally, there occurs an area which is rather narrow and striped ${ }^{3}$ as shown in the figures, P1. II, Figs. 9 and 12; it is, however, frequently reduced to a minimum, and as the valves, thereby, have their umbones placed closely together, the latter become much worn; the hingeleeth also suffering by this reduction of the area. The ribs, 30-36 in number, are flattened and broad. From the umbones downwards to the ventral margin the valves are frequently somewhat concave in the middle. REEve's figure certainly

${ }^{1}$ Catalogue of recent bivalve shells, p. 158. As Haxley in mentioning this species says: "with many ribs, which are grooved in the middle" it can hardly be the present species.

"Mantra \& Chemsirz, Conchyl. Cabin., loc. cit.

${ }^{3}$ Chimntz (loc. cit., VII, p. 197) says: "Der kleine zwischen den Wirbeln befindliche, etwas verticfte Raum wird von einen schwärzlichen lederartigen l3ande bedecket." 
does not represent Arca indica, Gm., more probably it is A. campechensis, Gm. (= A. americana, Gray). LAMARCK has also, undoubtedly, been mistaken with regard to $A$. indica, Gm. when, in his diagnosis, he says "testa ovata" and later on "costiis mediis sulco divisis." ED. V. MARTENs also supposes (as he writes in a letter to me) that LAMAnck has fallen into the same error as Ref.ve, and has had, lor examination, a specimen of A.campechensis, Gm.

\section{Arca (Trisidos) tortuosa, L.}

Area tortuos $\alpha$, Linví, Systema Naturx, ed. X, 1758, p. 693, No. 139. - ed. Xll, p. 1140, No. 168. XIII, p. 3305, No. 1; - Mus. Ludov. Ulr., p. 517, No. 89.

- - - Lamarck, Anim. sovert, éd. 2, VI, p. 460, No. 1.

- - - ReEve, Conchol. icon., II, Arca, Sp. 86.

- - - Martivi u. Chemnitz, Conchyl. Cabin., VIII, 2 Abth., p. 7, pl. 1, figs. 1-2.

- Crosse et Fischer, Journ. de Conchyl., vol. 37, 1889, p. 291.

'Parallelipedum tortuosum, LiNxé, Mohlet, Journ. de Conchyl., vol. 37, 1889, p. 163.

Arcu ('arallelepipedum) tortuosa, Linné, LAmy, Journ. de Conchyl., vol. 55, 1907, p. 108.

- torla, Stenstrep, Monch, Catal. conchyl. quie reliq. C. P. Kierulf, 1850, p. 33. - Catal. conchyl. qure reliq. Yoldi, II, 1853, p. 40.

NW. of Koh Chang, 10 fathoms, mud (1). Koh Lan, 30 fathoms, mud (1). W. of Koln Kut, 15 fathoms, mud (1/2). Between Koh Kahdat and Koh Kut, 6-10 fathoms, clay mixed with sand, shells $(1+y / 2)$.

Islands in the Gulf of Siam (MORLET).

Long. $10-28 \mathrm{~mm}$.

Distribution:- Malacca, Singapore, Madras, Gulf of Manaar, Bombay, Karachi, Persian Gulf, Gulf of Aden, Zanzibar. - Poulo Condor, Annam, China, Philippines, Banka-Strait, Moluccas, North-West Australia, Port Curtis (East Australia). ED. Smith ${ }^{1}$ is justified in rejecting KLEIN's name for the subgenus Parallclepipedum, as it dates from 1753; but he should use BoLten's name Trisidos, dating from 1798, and should not employ, as he does, OkEn's name Trisis, daling from 1815.

\section{Arca (Trisidos) semitorta, Lam.}

Arca semi-torta, LAMarck, Anim. sans vert., éd. 2, VI, 1835, p.460.

- semitoria, - IREFve, Conchol. icon., II, Arca, Sp. 89.

- (Parallelepipedum) semitorta, Lamarck, Martini u. Chemnitz, Conchyl. Cabin., Vili, 2 Abth., p. 134, pl. 35 , figs. $1-2$.

- (Trisis) semitorta, Lamanck, Edg. A. Smiтu, Report Challenger Lamellibr., p. 268.

- (Parullelipipelum) semitoria, LaManck, Crosse et Fischen, Journ. de Conchyl., vol. 40, 1892, p. 76. - - - LaMy, Journ. de Conchyl., vol. 55, 1907, p. 109.

Common between Koh Rin and Koh Kut, 1-38 fathoms, mud, sand and shells. The Gulf of Siam on the west coast of Cambodge (Crosse \& Fisciner).

Long. $4-83 \mathrm{~mm}$.

2 Repot on the Lamellibranchiata of the Challenger-Expedition, p. 268. 
Distribution:-- Persian Gulf, Gulf of Aden, Madagascar (Vofitzkow). Philippines, (ihina (IOngkong, Shanghai), North Australia, Torres Strait, Tasmania(?).

\section{Arca (Cucullaea) concamerata, Mart.}

Area coneamerata, Martixi, Beschäft. d. Berlin. Gesellsch. Naturf. Freunde, III, 1777, p. 292, pl. VII, figss. $15-16$.

- cucullata, - Conchyl. Cabin., VlI, p. 174, pl.53, figs. 526-28.

- Cucullus, G.sel., Syst. Nat., ed. XIII, p. 3311, No. 23.

Cucullec auriculifera, Lamanck, Anim. s. vert., éd. 2, VI, p. 454.

concameratu, Martixi, ReEve, Conch. icon., XVII, Cuculloe, Sp. 1 ,

Cucullaea - - Martivi u. Chemnitz, Conchyl. Cabin., vili, 2 Abth., p. 5, pl. 1, figs. 3-4; pl. 5, figs. $1-2$.

Cucullexa - _ - Lasy, Journ. de Concliyl., vol. 55, 1907, p. 306.

Cucullaca granulose, Jonas, Proc. Zool. Soc. London, XIV, 1846, p. 34.

- - ReEve, Conch. icon., XVII, Cucullara, Sp. 2.

- LaMy, Bull. du Mus. dHist. Nat. Paris, 1904, p. 278. - Journ. de Conchyl., vol. 55, ‘ 1907, [3. 306.

Koll Lan, 30 fathoms, mud (1). Koh Chuen, 10-30 fathoms $\left(2^{1 / 2}\right)$. Between Koh Chuen and Koh Chang, 15 fathoms, mud (4). S. of Koh Samit, 14-18 fathoms (1/2). Between Koh Kut and Koh Kahdat, 10 fathoms, shells (2). E. of Koh Mak, 20 fathoms, mud (1).

The Gulf of Siam, on the west coast of Cambodge (H. Crosse \& P. Fisciner, C. granulosa, Jon.). ${ }^{1}$

Long. 4-92 $\mathrm{mm}$.

Distribution:- Singapore, Mergui Archip., Nicobars, Madras, Tranquebar, Ceylon, Persian Gulf, Gulf of Aden, Red Sea (subfossil), Seychelles. - China, Formosa, Japan (Nagasaki), Torres Strait, New Caledonia.

I have specimens at hand from the Gulf of Siam which, with respect to the number of the outer lateral teeth agree entirely with the description of Cucullaca granulosa, Jonas (Reeve). 'The number of the teell in the latter form is, however, quite umeliable as a distinguishing mark, as the lateral teeth in at least the younger individuals (e, g. in individuals measuring $65 \mathrm{~mm}$. in length) pass into the rest of the row of teeth wilhout any interval or other separation.

\section{Pectunculus amboinensis, Gmel.}

Cardium amboinense, Gmils, Syst. Nat., cd. Xill, 1790, p. 3255, No. 43.

Arce peclunculus, Isivi, part. Syst. Nat., ed. X, p. 695, No.150. -- ed. XII, p. 1142, No. 180.

- - - Mantivi \& Culemsitz, part., Conchyl. Cabin., VIl, p. 235, pl. 58, figs. $568-69$.

'ectunculus pecliniformis, Iamack, part. Hist. nat. d. anim. sans vert., VI, 1 part. 1819, p. 53, No. 16. éd. 2. VI, 1835, P. 494, No. 16.

\footnotetext{
- - - Refve, Conchol. icon., I, P'eclunculus, Sp. 11.

- - - L. Moncet, Journ. de Conchyl., vol. 37, 1889, p. 163.

- peclunculis, Lixve, Eds. A. Smith, part., Proc. Zool. Soc. London, 1891, pp. 432-33.

1 Journ. de Conchyl., vol. XL, 1892, p. 76.
} 
Islands in the Guif of Siam (L. MorLet, loc. cit.).

The Danish Expedition to Siam collected no specimens of this species.

Distribution:- Mergui Archip., Ceylon(?). - Cochin China, Poulo-Condor, Philippines, Amboina. All the other localities recorded in the literature should no doubt be referred to "P. peclunculus L. (EDG. Sмiтн.)"

EDG. SMrth (loc. cit.) is of opinion that Linné (under the name of Arca pectunculus), Lamarck, and others have confused two well-distinguished Pectunculus species; one species in which the interstices between the ribs are rather broad and wellmarked as shown, for example, in SAvignx's figure (Descript. de l'Égy'pte, Corquilles, pl. X, fig. 2), and another species (the one we are here considering) in which the broad ribs stand close to each other, separated only by a groove, without any wellmarked interstices. Also, in the first-named species, the interior of the valves has a strong reddish-brown colour on the hinge-plate below the teeth, a feature which is said not to occur so pronouncedly in the olher species; but I am in doubt how far the latter is a constant character.

Limopsis cancellata, Reeve.

Pectunculus cancellatus, ReEve, Proc. Zool. Soc. London, XI, 1843, p. 188.

Conchol. icon., I, Pectunculus, Sp. 39.

Limopsis cancellata, REEVE, ËDG. A. SMTr., Report on the Lamellibranchiata of the Challenger Expedit., p. 256.

Woolwardi, A. Adass, Proc. Zool. Soc. London, 1862, p. 231 (fide Edg. Smith).

Dunker, Index molluscor. mar. Japon., p. 237, pl. XVI, figs. $5-6$.

- Philippii, A. Adass, Proc. Zool. Soc. London, 1862, p. 230 (fide Evg. Swith),

Arca multistriata, ForskîL, Descript. animal. qua in itin. orient. observ., 1775, p. 123 (fide A. H. CookE)

Pectunculus mullistrialus, Fonskì, ReEve, Conchol. icon., I, Pectunculus, Sp. 42.

Limopsis multisiriata, Fonskil, Słvigny, Descript. de lÉgypte. Coquilles, pl. X, fig. 3. juv., A. H. Cooke, Ann. and Mag. Nat. Hist., 5 Ser., vol. 18, 1886, p. 95.

W. of Koh Kut, 30 fathoms, sand and mud ( $\% / 2)$.

Long. 2-6 $\mathrm{mm}$., alt. $2-6 \mathrm{~mm}$.

Distribution: - Singapore, Gulf of Manaar, Arabian Sea (1at. $15^{\circ} 25^{\prime} \mathrm{N}$. long. $71^{\circ} 45^{\prime} \mathrm{E}$; in 191 fathoms), Red Sea, Suez. - Japan, Torres Strait, Mast Head Reef (Queensland), Port Jackson.

Limopsis Tenisoni, Ten. Woods ( $=$ L. cancellata, Ten. Woods non Reeve) from Tasmania and South Australia has been erroneously determined and referred to L. mullistriata, Forsk. ${ }^{1}$ by TATE and MAY.

\section{Fam. Mytilidae. Mytilus (Chloromya) viridis, L.}

Mytilus viridis, Lixné, Syst. Nat., ed. $\mathrm{S}, 1758$, p. 706, No.220. - Mus. Lud. U1r. 1764, p. 542, No. 138. Syst. Nat., ed. XII, 1767 , p. 1158, No. 259.

- - - Hanley, Catalogue of rec. hiv. shells, 1. 247.

1 For further details ef. Proc. Roy. Soc. Tasman., 1876 (1877), p. 156; 1877 (1879), p. 56. - Proc. Lim. Soc. New South Wales, 1901, 1) 437. - Scient. results of the trawling expedition of H. M. C. S. "Thetis" off the coast of New South Wales. Mollusea by C.Hedley, I, 1902. p. 297. 
Iytilus viridis, Linné, Hantey, Jpsa Linnei Conchylia, p. 145.

- - Dautzenberg \& Fischer, Journ. de Conchyl., vol. 5t, 1906, p. 211.

- Smaragdinus, Chemnitz, Conchyl. Cabin., VIIl, 1785, p. 166 , pl. 83, fig. 745 ; pl. 84, fig. 746.

- smaragdinus, - Reeve, Conchol. icon., X, Mytilus, Sp. 28.

- - $\quad$ - Martini u. Chemeitz, Conchyl. Cabin., Vili, 3 Abth.o p. 31, pl. 3, fig. 5 ;

pl. 13, figs. $1-2$.
- $\quad$ v. Martens, Proc. Zool. Soc. London, 1860 , p. 17.

- - - L. MorLeT, Journ. de Conchyl., vol. 37, 1889, p. 161.

- opulus, Lamarck, Hist. nat. d. anim. s. vert., VI, part. I, 1819, p. 124, No. 18. - éd. 2, VII, 1836, p. 43 , No. 18.

"Siam" (E. v. Martens, gathered by Mounot).

This species does not occur in the collections made by the Danish Expedition.

Distribution:- Singapore (Elera), Mergui Isls. (v. Martens), Delta of the Irawady in Pegu (Blanford), Madras (Melvill \& Standen, and others), Gulf of

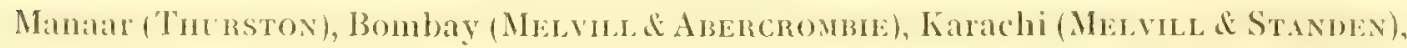
Persian Guif (v. Martens), Red Sea? (P. Fischer). - Cochin China (L. Monlet), Ben-Son, Annam (Bortav), Canton (Jones d Puestox), Hongkong (Mus. Zool. Univers. Hatun.), Shanghai (Fratenfend), Philippines (Ėizra), Borneo (Rrave), Auckland? (FMAUENELD).

Cinmitz records his species $M$. Smaragdinus from Trancuebar and Guinea.

\section{Modiola Hanleyi, Dunk.}

Modiola Hanleyi, Dunken, Index molluscor. mar. Japonici, 1882, p. 223, pl.16, figs.3-4.

Martini u. Chemitz, Concliyl. Cabin., Vill Bd., 3 Abth., p. 95, pl. 26, figs. 4-5.

S. of Koh Chuen, 30 fathoms, shells (1). Koh Kahdat, $1-5$ fathoms, sand with stones $(3)$.

Long. 9-49 $\mathrm{mm}$.

D istribution:- Singapore, shallow water (Sv. GaD). - Japan.

Several of the specimens from the Gulf of Siam were hidden in their nests of byssus-threads.

\section{Modiola rhomboidea, Hanl.}

Modiola shomboidea, Hanley, Martini u. Chemnitz, Conchyl. Cabin., Vili, 3 Abtlı., p. 103, pl, 26, fig. 10.

Gulf of Rayong, 7-10 fathoms, sand and mud (1). S. of Koh Samit, 20 fathoms, mud (2). Koh Chang, 3-5 fathoms, clay (1/2). W. of Koh Chang, 20 fathoms, mud (1). Off Koh Kut, 5 fathoms (1).

Long. $16-35 \mathrm{~mm}$.

Distribution:- Charbar and Gulf of Oman (Melvill \& Standen). - China (Coll. Paetel), Japan (DunkER).

Like many other Modiola-species, the present species spins a kind of protecting nest of byssus- threads, which almost covers the animal. The specimens from the Gulf of Siam agree exactly with the figure in MarTinı u. Cuemnitz; but I find that REEve's figure and description (Conchol. icon., X, Modiola, Sp. 28) much more closely 
resemble $M$. elongata, Sivs., for instance; and his statement of "The Gambia, West Africa" as the locality, also makes it doubtul whether the species he describes and figures is the same as that recorded from the Asialic waters. Both REEvE and Chessin give "Hanley, Species Recent Shells" as the place where the species was first described; it is, however, not to be found there at all, and I have not succeeded in discovering where HaNLEY's original description is to be found.

\section{Modiola elongata, Sws.}

Modiola elongala, Sivainson, Exotic Conchology, 1821, Part I. Second edit., 1841, p. 31, fig. 8.

- $\quad$ - $\quad$ REEve, Conchol. icon., $\mathrm{x}$, Modiola, Sp. 4.

- - _ Martini u. Chemsitz, Conchyl. Cabin., VIII 13d., 3 Abth., 1). 97, 11. 27, figs. 1-2.

N. of Koh Kahdat, 4-5 fathoms, coarse sand (2). W. of Koh Chuen, soft clay and mud $(3 / 2)$.

Long. $45 \mathrm{~mm}$.

Distribution:- Moluceas, Aru Isl, Sorong (Taplparone Canefri), Jobi Isl. (Geelwinck Bay).

\section{Modiola Metcalfei, HanI.}

Modiola Melcal/el, Hanlis, Proc. Zool. Soc. London, XIl, 1844, p. 14.

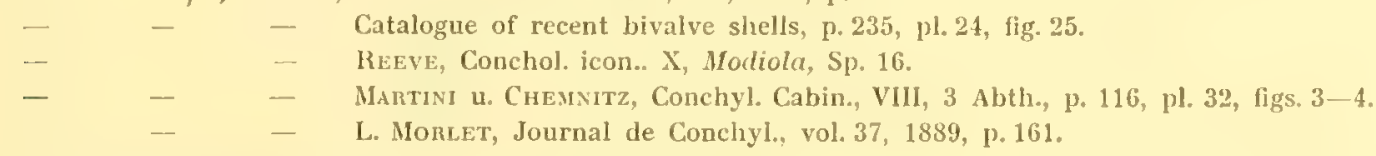

Islands in the Gulf of Siam (L. MonLET).

This species does not occur in the collections made by the Danish Expedition. Distribution:- Madras, Gulf of Manaar. - Philippines, China (Hongkong), Japan (Nagasaki), Malay Archip., Ratack Isls. (Marshall Isls.).

\section{Modiola plumescens, Dunk.}

(P1. II, Figs. 13-14).

Perna (Modiola) plumescens, Duxren, Museum Godeffroy, Catalog IV, 1868, p. 115. - V, 1874, p. 175 (no description).

Modiola tumescens, Dunker, (Clessin) Martini u. Chemnitz, Conchyl. Cabin., Vill Bd., 3 Abtlı., p. 129, pl. 33, figs. $8-9$.

Common between Koh Kram and Koh Kut, 1-30 fathoms, sand and shells.

Long. $3-30 \mathrm{~mm}$.

Distribution:- Viti and Samoa Isls. (Dunker), Java, Amboina and Banda (ED. v. Martens in litt.).

I was at first of opinion, that the present species should most properly be referred to Mod. barbata L., ${ }^{1}$ which it greatly resembles in form and colour; for instance, the epidermal prolongations in my specimens agree exactly with those

1 Taken at Japan by the Challenger Expedition. 
of European specimens of Mod. barbata L.; but as the material at my disposal for comparison, was insufficient to decide this question, I sent some specimens to Prolessor ED. v. Martins. He informed me that he considered them to be: "plumescens, Dunker; Cuessin beschreibt u. bildet sie ab, aber unter dem Namen tumescens, wahrscheinlich nur aus Irrhum (falsches Lesen)." "The confusion introduced by CLessin into science by his "Monographs" in the new edition of Martini d CHeMnitz: "Conchylien Cabinet" is much to be regretted. EDG. SMrru mentions, in his report on "Alert's" zoolorical results, " Modiola sp. (taken at Port Molle) "remarkably like the European M. barbata;" it is probably the present species.

\section{Modiola Philippinarum, Hanl.}

Holiola Philippinarm, HANueY, Proc. Zool. Soc. London, XIJ. 1844, p. 15.

- $\quad$ - C Catalogue of rec. bivalve shells, p. 235, pl. 24, fig. 26.

- - - ReEve, Conchol. icon., X, Modiola, Sp. 1.

- - - Rochebrune, Bull, de la Soc. Philomath. de P'aris, 29/10 1881 (Repro), p. 6.

- philippinarum, - Eng. Surтn, Ann. and Mag. Nat. 1łist, 7 Ser., XVIII, 1906, p. 254.

Perna fulgilia, I1. Anssis, Proc. Zool. Soc. London, 1870, p. 7, pl. 1, fig. 9.

E. of Cape Liant, 9 fathoms, shells (1). Between Koh Rin and Clilf Rock, 15 fathoms (2), Koh Kram, 30 fathoms $\left(1^{1 / 2}\right)$.

Long. 2-41 $\mathrm{mm}$.

Distribution:- Persian Gulf (Edg. Smtri), Red.Sea (Mac Andrew, Cooke).

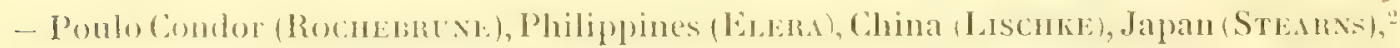
Amboina and Larentulia (v. MARTEns), Kei Bandan (Tapparone-Canefri), Jobi Isl. (Geelwinck Bay)?, Torres Strait (Melvill \& Standen), Mast Head Reef, Queensland (HEDLEY).

ED, y. MARTens ${ }^{3}$ supposes that Mod. Rumphii, Phil. is synonymous with $M$. Philippinarum, Hani. In the specimens from the Gulf of Siam the interior is whitely-iridescent.

\section{Modiola Evansi, Smith.}

Hodiola evansi, Eng. Swrm, Journ. of Conchology, X, 1903. p. 368.

'Tale Nawi in Lower Siam (Ricr. Evans).

This species does not occur in the collections made by the Danish Expedition.

EDG. SMTH says with regard to the locality from which this species has been taken: "This semi-lake is probably brackish water, being almost enclosed from the sea, and having several rivers and streams ruming into it."

1 Report on the zoolog. collect. made in the Indo-Pacific Ocean during the voyage of II. M. S. "Alert", $1881-1882$. Lond. 1884, p. 108.

2 Witli reference to $I . V$. SchusNcr's statement concerning the occurrence of the species at North Japan, and its synonymy with M. modiolus L. cf. L. V. Scurnexck, Mollusken d. Amur-Landes, p. 498 , and C. L. Lischis, Japanische Meeres Conchylien, 1, p. 156.

liumphius Gedenkboek, 1902, Mollusken, p. 128 (20). 


\section{Modiola lignea, Reeve.}

Moliola lignea, Relive, Conchol. icon., X, Modiola, Sp. 58, pl. X, fig. 71.

Mahtivi u. Chemnitz, Conchyl. Cabin., VIII, 3 Abth., p. 102, pl. 27, fig. 3.

S. of Koh Chuen, 30 fathoms, shells (2). Koh Kahdat, 1-5 fithoms, sand (1).

Long. $15-20 \mathrm{~mm}$.

Distribution:- Gulf of Aden (Shopland), Red Sea (Sturany). - Torres Strait (Melvill \& Standen), Australia (Clessin), Port Elizabeth (Sowerby).

No locality was given for REEve's original specimens in Cuming's collection; the species has since been found on the coasts of Australia and South Africa. It is also recorded from the West Indies, but this is undoubtedly due to erroneous determination. W. H. DALL states, in the report on the Mollusca of the Blake Expedition, that he has specimens from the east and west coasts of Florida; and elsewhere? $^{\text {? }}$ he states that it occurs along the east coast of America from S. Carolina to St. Thomas. I have in my collection, specimens from St. Thomas, collected by A. H. Ruse, and determined by Morch as M. Lignea, Reeve; but the most important distinguishing characters of this species - the well-marked and conspicuous lines of growth on the front and hinder parts, while the middle is smooth - do not occur at all in these specimens, which are perfectly smooth all over the valve; nor, in DALL's description of the Mollusca of the Blake Expedition are these characters mentioned. The American specimens undoubtedly belong to another species.

\section{Modiola arcuatula, Hanl.}

Modiola arcuatula, Havesy, Proc. Zool. Soc. London, XII, 1814, P. 16.

$\begin{array}{lllll}- & - & - & \text { Regve, Conchol, icon., X, Modiola, Sp. 27, figs. } 27 \text { and } 45 . \\ \text { - } & - & - & \text { Martini u. Chemsitz, Concliyl. Cabin., VIII, } 3 \text { Abtlı., p. 101, pl. 30, figs. 8-9. } \\ \text { - } & - & - & \text { L. Morlet, Journ. de Concliyl., vol. 37, 1889, p. 161. } \\ \text { - } & - & - & \text { P. Fischer, Catalogue d. Mollusques de l'Indo-Chine, p. } 212 .\end{array}$

Siam (P. Fischer). Cambodge, at the exit of the river Kampong-Son (L. MorLet). This species does not occur in the collections made by the Danish Expedition. Distribution:- Singapore, Mergui Isls. - Cochin China, Japan, Philippines, Java.

\section{Modiola glaberrima, Dunk.}

Volsclla glaberrima, Dunken, Proc. Zool. Soc. London, XXIV, 1856, p. 363, No. 16.

Modiola - $\quad$ - ReEve, Conchol. icon., X, Modiola, Sp. 48.

- - _ Mantivi u. Chemsitz, Conchyl. Cabin., VIII, 3 Abth., p. 99, pl. 27, tigs. 7-8.

- - - EDG. A. Smit, Report on the Lamellibranchiata of the Challenger Exped.. ค. 275.

NW. of Koh Chang, 10 fathoms, mud ( $\left.{ }^{2} / 2\right)$. S. of Koh Chuen, 30 fathoms, shells (3). S. of Koh Samit, 20 fathoms, mud (1/3). Sound of Koh Chang, $3-5$

1 Report on the Mollusca. "Blake" Expedition, 1877-80, I, p. 236. Cambridge 1886.

2 W. H. Dall, Catalogue of the shell-bearing marine Mollusks and Brachiopods of the south-castern coast of the United States. Washington 1889 , pp. 38-39. 
lathoms, soft clay (1). W. of Koh Chang, 20 fathoms, clay (1). S. of Koh Kahdat, 8-10 fathoms, mud (2). W. of Kioh Kut, 30 fathoms, sand and mud (1).

Long. 4-35 mm.

Distribution:- Mergui Archip., Suez. - Canton, East Australia (the districts around Sydney). 1

'The specimens from the Gulf of Siam are all provided with a very shiny, greenish epidermis and several were either completely or partly hidden in their "nest" of byssus-threads, and fragments of shells, pebbles, etc. were partly attached to and partly entangled in these threads. Modiola perfragilis, Dunk., ${ }^{2}$ M. Japonica, Dunk., M. angusta, Cless.," and M. cultellus, Desh., 4 are closely allied species. P'rofessor ED. V. MARTEns, to whom I sent some specimens of the present species from Koh Samit, writes as follows: "Modiola perfragilis "Reeve" von d. Molukien ist wohl Jugendzustand von glaberrima."

\section{Brachyodontes (Hormomya) subramosus, Hanl.}

Modiola subramosa, HanteY, Proc. Zool. Soc. London, XII, 18t4, p. 14.

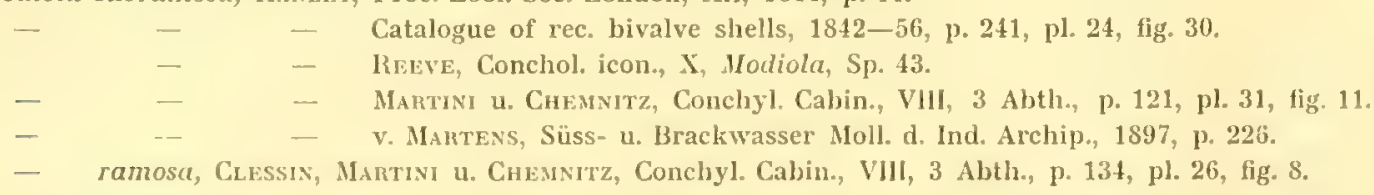

West coast of Koh Chang, 1 fathom, old coral blocks (4). Koll Kahdat, 1 fathom, sand (1).

Long. $7 \mathrm{~mm}$.

Distribution:- Mindanao and Samar, Philippines (Cumng and JAgor), Ternate, Moluceas (Duniris's collect.), Celebes (Pätrés collect.), the Gulf of Amboina (Rumpi and v. Martens), Sorong (Tapparone Canefri), New Caledonia (Frauenfeld).

According to v. MARTENS, ${ }^{5}$ it is said to be able to live in brackish water and (in the Phillipines) perhaps even in freshwater. F. P. Marratt ${ }^{6}$ records it (but this is surely an error) as obtained by the "Argo Expedition" at Abaco (Bahama Islands). Swainson's name Brachidontes, as a sub-genus of Modiola, was altered to Brachydontes by P. Fischer, and afterwards by Jukes-Browne? to the generic name Brachyodontes.

1 L. v. Mantexs, Süss- u. Brackwassel Mollusken d. Indisch. Archipels, p. 87.

- It is strange that I)UNKen (Proc. Zool. Soc. Lond., 1856, p. 362) in his diagnosis of this species from Cuming's collection says: "testa ... parum splendida." RiEve, on the contrary, characterizes the same specimens as "shining" (nitente).

${ }^{3}$ Probably identical with $M$. perfragilis, Dunk.

"Magaz. de Zoologie éd. p. Guérin-Méneville, II, 1840, pl. 13, "from Kantschatka" is undoubtedly synonymous with M. glaberrima, Dunk.

5 Loc. cit. p. 226.

(3iggins and Manratt, Mollusca of the Argo Expedition to the West Indies, 1876, Liverpool Museum lieport, No. 1, 1878, p. 423.

7 Proceed. Malacolog. Soc. London, vol. VI, 1905, pp. 221-23. 


\section{Brachyodontes emarginatus, Bens. (Reeve).}

Modiola emarginatus, Benson, M. S. in Mus. Cuming.

- - - REeve, Conchol. icon., X, Modiola, Sp. 60, pl. X, fig. 73.

Perna emarginala, - Rochebruxe, Faune malacol. de la Cochinchine et du Cambodge, Suppl., Bullet. de la Soc. philomath. de Paris, 10/12 1881, (Repr.) p. 4, No. 17.

Modiola P. Fischer, Catal. d. Moll. de I'Indo-Chine, p. 212.

Matrtini u. Chennitz, Conchyl. Cabin., Vuli, 3 Abth., p. 114, pl. 26, fig. 3 (according to v. Martexs not p. 120, pl. 25, figs. 7-8, these probably being II. Fortunei, Reeve).

- - - v. Martens, Süss- u. Brackwasser Moll. d. Ind. Archipels, 1897, p. 227.

Koh Kahdat, $1-5$ fathoms, sand (3). Strand of Koh Kahdat (fragments).

Long. $25 \mathrm{~mm}$.

Distribution: -- The coast of Birma, in brackish water (BLANFord), Bombay (Melvill \& Abercrombie), Calcutta (v. Martens), Poulo Condor (Rocheirune), Philippines (ELERA).

\section{Septifer bilocularis, L.}

Ifylilus bilocularis, Linné, Systema Nat. ed. X, 1758, p. 705, No. 212. - ed. XII, p. 1156. - Mus. Ludov. Ulrice, 1764 , p. 540 .

Tichogonil - - Martinı u. Chemnitz, Conchyl. Cabin., Vill Bd., 3 Abth., p. 10, pl. 2, figs. 11-17.

Septifer - - Dunker, de Septiferis gen. Mytilaceorum et de Dreisseniis, 1855, p.6.

- - - - Evg. A. Sмiтн. Challenger Exp. Lamellibranchiata, 1885, p. 271.

- $\quad$ - _ P. Fischer, Catal, d. Moll, de l'Indo Chine, p. 214.

- Dautzenberg \& Fischer, Journ. de Concliyl., vol.53, 1905, p. 450.

Mytilus Nicobaricus, Chemsitz, Conchyl. Cabin., VIIl, 1785, p. 155, pl.82, figs. 736-37.

- ReEve, Conchol. icon., X, Mylilus, Sp. 42.

Very commonly distributed between Koh Kram and Koh Kut, 1-30 fathoms, sand, shells, mud and gravel; between old coral blocks.

Long. 3-48 $\mathrm{mm}$.

Distribution:- Singapore, Strait of Malacca, Nicobars, Andamans, Aracan coast, Ceylon, Mahlos Atoll (Maldive Archip.), Persian Gulf, Red Sea, Seychelles, Amirantes, Madagascar, Mascarene Isls., Querimba Isls., Zanzihar, Mozambicue, Natal. - Poulo Condor, China, Tonkin, Hongkong, Janan (Nagasaki), Philippines, Sumatra, Christmas Isl., Celebes, Sulu Isls., Moluceas, Sunda Isls., Aru Isl, Sorongs, New Guincat. Salomo Isls., Torres Str., East Australia, New Caledonia, Marianne Isls., Viti Isls., Paumotu Isl.

This species, which varies greatly, both in regard to colour and form, has presented to many authors the temptation of forming new species. EDG. Sintr, in his report of the Lamellibranchiata of the Challenger Expedition (1). 271), has enumerated various synonyms, and undoubtedly some more may be added. JukEsBrowne ${ }^{1}$ gives the gen. Septifer as a sub-genus of Brachyodontes.

1 Proc. Malacolog. Soc. London, vol. VI, 1905, p. 223. 


\section{Septifer excisus, Wiegm.}

Tichogonia excisa, Wiegnave, Archiv f. Naturgeschichte, III, 1837, p. 49.

Septifer cxcisus,
Mytilus -

Koh Lom, W. of Koh Chang (2).

West Coast of Cambodge in the Gulf of Siam (PAvie).

Long. '21-26 mm.

Distribution: - Mergui Isl., Karachi, Gulf of Aden, Red Sea (pleistocene), Mauritius, Madagascar, Mozambique, Querimba Isls. -- Funafuti (Ellice Isl.).

Tichogonia (Septifer) siamensis, Clessin" from "Siam," and also Septifer Troscheli, Dkr., ${ }^{2}$ undoubtedly belong to the present species. CLEssin ${ }^{3}$ knows Septifer excisus, Wiegm. only from DunkEn's description, and has hardly any clear conception of it; neither has he examined ReEve's figure, as he writes: "Reeve hat dic Art nicht abgehildet, trolzdem sich dieselbe in der Cuming'schen Sammlung befinden muss."

\section{Lithodomus gracilis, Phil.}

Modiola (Lithophagus) gracilis, PHicippi, Zeitschr. f. Malakozool., 1847, IV, p. 117.

- gracilis, I'nitipri, Abbild. u. Beschreib. neuer od. wenig gek. Conchyl., 1851, III, p. 5 (19), pl. II, tig. 1.

Lithodomus grucilis, Phuspl, RErve, Conchol. icon, $\mathrm{X}$, Lilhodomus, Sp. 4.

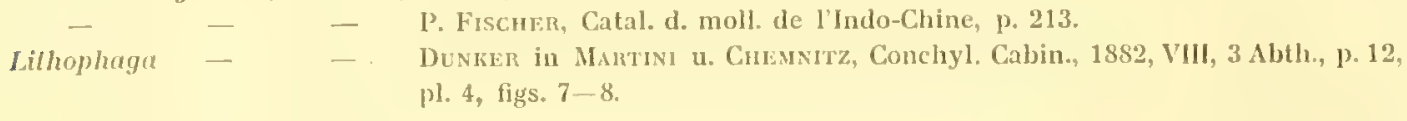

North end of lioh Chang, 1-12 fathoms, old coral blocks (many specimens). Koh Kahdat, 1 fathom, sand (9).

Long. 11-72 $\mathrm{mm}$.

Distribution:- Malacea, Mergui Isls, Madras, Ceylon, Mahlos-Atoll Maldive Archipel.), Red Sea, Seychelles, ${ }^{4}$ Amirantes, 'Tschago's Isls., Mauritius, Bourbon, Querimba Isls., Zanzibar. - Poulo Condor, China (Shanghai), Sunda Isls. (Java, Flores, and others), Amboina, Sorong, Torres Strait, north-west Australia, Tahiti.

With regard to the three closely allied forms - L.teres, Phil., L. gracilis, Phil., and L. niger, d'Orb. - I do not doubl, judging from the material at hand, that L.teres, Phil., is identical with L. gracilis, Phil. E. v. Martens has already stated in "Die Mollusken d. Maskarenen u. Seychellen," (p. 143) that L. teres, Phil., cannot be separated as a species from L. gracilis, Phil. (Chemsitz's figure ${ }^{5}$ of Mylilus litho-

I Martini u. Chismit\%, Conchyl. Cabinet, Vlli, 3 Abth, pp. 19-20, pl. 15, figs. 8-9.

2 W. I) Unken, Neue Mytilaceen, Zeitschr. f. Malakozool., X. 1853, p. 87.

3 loc. cit., 1). $24-25$.

PH. DAutzaneng records it (Bull. de la Soc. Zool. de France, 1893) from here, and says: "Lithodomus gracilis Philippi, indiqué par von Martens sous le nom de Lo teres l'bilippi.'

Cuj:mity, Conchyl. Caljinct, VIll, 1785, pl. 82, fig. 729. 
phagus" from St. Maurice and Bourbon agrees exactly with L.gracilis, Phil, but yet Philppi and Dunker refer it to L. teres, Phil.). Dunker ${ }^{1}$ thinks that L. teres is closely analogous to L. niger, d'Orb. (=L. Antillarum, Phil.), and is perhaps only a variety of the same. 'I'he reason for this must be sought in the opinion expressed in his diagnosis of $L$. teres, Phil.: "epidermis nigro-castanea, in dorso et subter umbonibus laevis, in latere ventris simili modo striata ac in Lithophaga nigra." 'The most important mark of distinction between the West Indian L. niger, d'Orb., and the East Indian L. gracilis, Phil., is, as far as I can see from the material at my disposal, precisely this epidermal striation. In L. gracilis, Phil., these transverse lines extend almost to the anterior end (diminishing gradually in size) and only a small portion of the outermost part of that end is quite smooth; in the posterior part, the striation is usually continued somewhat farther than in L. niger. On comparing two specimens - one of each of these species - of equal size (e. g. $49 \mathrm{~mm}$.), the result will be as follows: in L. niger (from St. Thomas) the striation is continued beyond $32 \mathrm{~mm}$, as measured along the lower margin of the shell, while in L. gracilis (from the Gull of Siam) it covers $40 \mathrm{~mm}$.

\section{Lithodomus straminea, Dunker.}

Lithodomas stramineus, DUnKer, RFEVE, Conchol. icon, X, Lithodomus, Sp. 11.

Lithophaga straminea, - Dunker in Martini 4. Chemsitz, Conchyl. Cabin., VIII, 3 Abth. A, p. 6, 1). 2 , figs. $1-2$.

Koh Chang, very low tide (1).

Long. $22 \mathrm{~mm}$.

Distribution: - Madras (Meluid, \& STanden), the Gulf of Manaar (Thunston).

- Mast Head Reef, Queensland (HedLey).

'The habilat "West Indies" given in Cumng's collection, is undoubtedly due to an error.

J. MABILLE and G. LE MEsil: record ${ }^{2}$ Lithodomus lithophagus L. from Poulo Condor; Crosse ${ }^{3}$ is right in doubting the correctness of this determination. Is it not more probably L. straminea, Dkr., that has been found?

Lithodomus Malaccana, Reeve.

Lithodomus Malaccana, Refve, Conchol. icon., 1858, X, Lithodomus, Sp. 20.

Lilhophaga Malaccana, - Manxixi u. Chesnitz, Conchyl. Cabin., VII, 3 Abth. A, p. 20 , pl. V, fig. 1.

Lithodomus subula, _ Conchol. icon., X, Lithodomus, Sp. 26.

Lithophaga - - Martini u. Chemsitz, Concliyl. Cabin., Vili, 3 Abth. A, p. 21, pl. V, fig. 13 (figs. 11-12?).

- cavernosa, Dunker, Mamtin u. Chemnitz, loc cit., p. 7, pl. II, figs. 5- 6; pl, V, figs. 15-16

- reliculata, - $\quad$ - loc. cit., p. 19, pl. V, figs. 9-10.

' Martini u. Chemnitz, Conchyl. Cabin., VIII Bd., 3. Abth., p. 13.

2 Journal de Conchyl., XIV, 1S66, p. 118.

${ }^{3}$ loc. cit. p. 119.

1), K. 1), Vidensk, Selck. Stur, 7. Rackke, naturvidensk. of mathem. Ard. V. a 
Several specimens were taken between Cape Liant and Koh Kahdat in 1-15 fathoms, boring in old coral blocks, and from sandy bottom. Toung specimens were taken from inud and stony bottom.

Long. 6--26 $\mathrm{mm}$.

Distribution: - Malacca, Mergui Archip, the Gulf of Manaar (Thunstov), Karachi? (Melvill \& Standen), Persian Gulf (Annandale), Hulule Isl. (Edg. Smitu), Zanzibar and Aldabra Isl. (Voeltzkow). - Philippines, New Guinea, Cape York, North Australia ("Chaldenger"), New Caledonia, Tahiti.

The present species, like all boring Molluses, is subject to great variation in regard to form; I have put L. subula, Reeve, and Dunien's L. cavernosa and reticulata as synonymous forms, and several more could no doubt be added. Cir. HEDLEX ${ }^{1}$ supposes that L. levigata, Q. and $\mathrm{G}_{0}{ }^{2}$ is the same species as L. Malaccana, Reeve; should this prove to be the case, ReEve's name for it must yield to that of QUOY and GamanD, which has the priority. Besides boring holes in coral blocks, shells, and similar objects, this species often makes free "chalk houses," there is, for instance, a specimen of Chama multisquamosa, Reeve from Koh Kahdat, in one of the valves of which two individuals of $L$. Malaccana have made their two "houses" side by side; these are smooth interiorly, agreeing exactly in form with that of the Lithodomus-valve, and their only communication with the outer world is through an oblong hole bored in the valve of the Chama.

\section{Lithodomus (Botula) cinnamomea, Chemn.}

Mytilus cinnamominus, Chemsitz, Conchyl. Cabin., VIII, 1785, p. 152, pl.82, fig. 731.

IIodiola cinnamomea, Lamarck, Encyclop. méthod., pl. 221, fig. 4.

Lithodomus cinnamominus, Chemsitz, ReEve, Conchol. icon., $\mathrm{X}$, Lilhodomus, Sp. 5.

- cinnamomeus, - Fischer, Catal. d. Moll. de I'Indo-Chine, p. 213.

Mytilus fuscus, GMerin, Syst. Nat., ed. XIII, P. 335\%, No. 35.

Lithophaga fusca, Gmin, Martini u. Chemnitz, Conchyl. Cabin., VIII Bd. 3 Abth., p. 25, pl. 6, figs. $8-9$. Modiola silicula, Lamanck, Anim. s. vert. VII, 1836. p. 25, No. 19.

Common from Cape Liant to Koh Chang, 1-30 fathoms, in old coral blocks, on stony and shelly bottom.

Long. 2-28 $\mathrm{mm}$.

Distribution: - Mergui Archip., Nicobars, Ceylon, Suvadiva Atoll (Maldive Archip.), Karachi, Red Sea, the Gulf of Aden, east coast of Africa, Seychelles, Mauritius, Bourbon. - Poulo Condor, Annam, Philippines, Torres Strait, Mast Head Reef (Queensland), north-west Australia, New Caledonia, Paumotu Isl. - East coast of America from Cape Fear to Guadaloupe.

I agree entirely with CRosSE and Fiscren when they ${ }^{3}$ write concerning Cinmentz's species from the Nicobars: "Est-il réellement identique à la forme analogue des Antilles?" The material at my disposal unfortunately is not con-

1 Australian Museum, Sydney, Memoix III, 1896-1900, 1. 492.

2 Voyage de l'Astrolabe, III, p. 46t, pl. 78, figs. 17-18.

3 Journal de Conchyliologie, XXXVII, 188\%, p. 29). 
siderable enough to decide the question. - The specimens from the Gulf of Siam, which agree most closely with the form figured by REEve in P'I. I, Fig. 5b, liave all a dark-brown epidermis and strongly marked, broad, step-like zones of growth. Also forms like Lamarck's Mod. silicula occur frequently.

\section{Modiolaria Cumingiana, Dunker (Reeve).}

Modiola Cumingiana, Dunken, MS. Mus. Cuming.

\begin{tabular}{|c|c|c|c|}
\hline - & - & - & VE, Conchol. icon., X, 1857, Modiola, Sp. 50 \\
\hline & & & 11. Chemitit, Con \\
\hline & ningiana, & & Report Challenger Exped. Lamellibranchiata, 1885, p. 278. \\
\hline
\end{tabular}

Koh Kram, 20 fathoms (1/2). Belween Koh Riol and Koh Mesan, 3-5 fathoms, sand (1).

Long. 8-11 $\mathrm{mm}$.

Distribution: - Karachi (Melvild e Standen), Gulf of Aden (Shopland), Red Sea (Sturany), Mauritius (Liénard), Natal (Edg. Smitr). - Japan (Dunker and STEARNs). Along the north ('Torres Strait, and several other places), east (Moreton Bay, Sydney, and several other places), south (St. Vincent's Gulf, and several other places) and west coast (Swan River, and several other places) of Australia. Tasmania (TATE and MAx).

\section{Modiolaria cuneata, Gould.}

Modiolaria cuncala, Goucd, Proceed. of the Boston Soc of Nat. Hist, VIII, 1861 - 62, 13. 38.

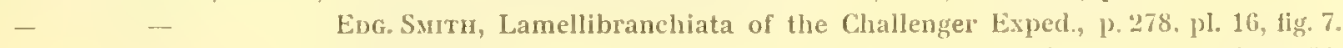

Pirtchand and GatlifF, Proceed. Roy. Soc. Victoria, vol. 17; pt. 1, 1904, p. 254.

Koln Kahdat, 1-2 fathoms (1).

Long. $4 \mathrm{~mm}$.

Distribution: - Port Jackson, Sydney ("Challenger"), False Bay, Cape of Good Hope (Govld). "Common Port Phillip, associated with tunicates, Carrum to Frankston, Portsea" (Pritchard and Gatliff).

Mod. coenobita, Vaillant, from Suez, ${ }^{1}$ is closely allied to this species.

\section{Modiolaria nana, Dunk.}

(I'l. II, Fig. 15).

Lanistina nana, Dunker, Proc. Zool. Soc. London, XXIV, 1856, p. 365.

Modiola - - ReEve, Conchol. icon., X, Modiola, Sp.56, pl. X, fig. (69.

Crenella - - Clessix in Martixi u. Chemsitz, Conchyl. Cabin., Vili, 3 Abtl., p. 152, pl. 31 , lig. 10 .

1 Journ. de Conchyl., vol. 13, 1865, pp. 122-123, SAvigxr, Descript. de l'Égypte. Cocpuilles, pl. XI, fig. 3. A. H. Cooke (Anu. and Mag. Nat. Hist., Ser. 5, vol. 17, p. 141) considers it to be identical with Mod. marmorata, Forb. EdG. Sarth (Proc. Zool. Soc. London, 1891, pp. 393-9t) thinks, lowwever, that Cooke is wrong in this. Soweruy (Marine shells of South Africa, p. 65) lias specimens from L'ort Elizabetl. 
Gulf of Rayong, 7-10 fathoms, mud (7/:). Koh Kram, 30 fathoms (1/2). Between Koh Mesan and Cape Liant, 5-9 fathoms (3/2). Koh Kahdat, $1-5$ fathoms, sand $(2 / 2)$. Long. 4-13 $\mathrm{mm}$.

Distribution: - Port Lincoln, South Australia (Cuming), Sullivan Isl., Mergui Archip. (v. Mantens).

Dunker and ReEve give the size of the specimens in Cumng's collection as $4 \mathrm{~mm}$.; from the Gulf of Siam there are specimens measuring as much as $13 \mathrm{~mm}$. REEvE's figure (very badly reproduced in CLEssin's Monograph in "Marlini \& Chemnitz") is not good in all points, hence I have given a new figure here. As all the specimens from the Gulf of Siam were taken dead, I have not been able to verify Duxker's statement: "Pagina interna margaritacea."

\section{Modiolaria miranda, Edg. Smith.}

Modiotaria miranda, EDG. SmitH, Rep. Zoolog. Collect. made during the voyage of I1. M. S. "Alert," 1881, p. 108, pl. 7 , fig. N.

Common (from 16 different localities) between Koh Rin and Koh Kut, 1-30 fathoms, stones, shells, gravel and mud.

Long. $1-7 \mathrm{~mm}$.

I) istribution:- Dundas Straits.

Some of the specimens were taken from among the spines of Stephanocidaris bispinosa, Lam., from a depth of 30 fathoms.

Modiolaria (Gregariella) opifex, Philippi (non Say).

Modiola opifer (SAY?), Phurrer, Abbild. u. Beschreib. neuer od. wenig gekannt. Conchyl., III, 1851, Modiola, p. 21 (7), pl. II, fig. 7.

SAx, ReEve, Conchol. icon., X, Modiola, Sp. 39.

lithophaga opifex, SAy, Dunken in Martini u. Chemsitz, Conchyl. Cabin., VliI, 3 Abth. d, 1). 26, pl.6, fig. 16.

Lithodomus splendidus, ReEve (non Duxken', ReEv, Conchol. icon., X. Lithodomus, Sp. 31.

Between Koh Mesan and Koh Chuen, 25-38 fathoms, stones (7). Between Kolı Mesan and Cape Liant, 5-9 fathoms $\left({ }^{1} i_{2}\right)$.

Long. 9-15 $\mathrm{mm}$.

Distribution:- Sydney (Cumsg). - Brazil (Hexr. Knoyer; Desterro, Fr. Müller; Rio Janeiro, Cuming).

In all the specimens from the Gulf of Siam the most posterior, flattened part of the valves, limited by ridges set with stiff epidermal bristles, was covered with adherent grains of sand; this gives the animals, which live buried in the sand, a great resemblance to their surroundings. Modiola difficilis, Deshayes, ${ }^{1}$ appears to me to resemble more particularly a worn specimen of the present species.

1 Mollusques de l'ile de la Réunion (Bourbon), 1863, p.23, pl. 3, figs. 22-24. 
Modiolaria (Gregariella) coralliophaga, (Chemn.) Gmel.

Mytilus coralliophagus, Chemertz, Conchyl. Cabin., VIII, 1785, p. 174, pl. 81, fig. 752. - - - _ - GuElix, Syst. Nat., ed. XIII, 1790, p. 3359, No. 31.

Modiola semen, LaMarck, Anim. s. vert., éd. 2, VIl, 1836, p. 26, No. 21.

- opifex, SAX (non Phrıpp), Journ. Acad. Nat. Sc., Philadelphia, IV, 1825, p. 368, pl. 19, fig. 2.

- - - Verrill \& Busch, Trans. Connecticut Acad. X, 1900, p. 516, pl. 58, fig. 3.

- divaricata, Pницгpr, Zeitschr. f. Malakozool., 1847, p. 115.

- - - $\quad$ Abbild. u. Beschreib. neuer od. wen. gek. Conchyl. Modiola, p. 21 (7), pl. II fig. 8 .

Lithodomus divaricalus, Phicippi, Reeve, Conchol. icon., X, Lithodomus, pl. V, Sp. 34.

Lithophagre divaricata, Phinipri, Martixi u. Chessit\%, Conchyl. Cabin., VIII Bd. 3 Abth. A, p. 26.

Modiolaria _ _ - LtSchise, Japanische Meeres Conchyl., II, p. 148.

At the north end of Koh Chang, 1-12 fathoms, in old coral blocks (6).

Long. 7-13 mm.

Distribution: - Japan, Nagasaki (Lischke). - East coast of America from Cape Hatteras and the "Lesser Antilles" to Rio Grande do Sul.

The specimens from the Gulf of Siam agree in all points with the specimens from the West Indies.

\section{Fam. Pteriidae.}

\section{Pteria spectrum, Reeve.}

Avicula spectrum, REEve, Conchol, icon, X, 1857, Avicula, Sp. 59.

Dunker in Martivi u. Chemsitz, Conchyl. Cabin., VII, 3 Abth., 1872, p. 49, pl. 17, fig. 1.

Koh Chuen, 30 fathoms (1).

Long. $22 \mathrm{~mm}$., alt. $11 \mathrm{~mm}$.

Distribution:- Philippines.

I have compared the small specimen from Koh Chuen with ReEve's original specimen in the British Museum, and although somewhat different I cannot see that it can be referred to any other species than to P. spectrum, Reeve.

\section{Pteria serrulata, Dunk.}

Avicula serrulata, Dunken, Zeitschr. f. Malakozoologie, V, 1818, p. 178.

- - - Martin u. Chemnitz, Conchyl. Cabin., Vil Bd. 3 Abth., p. 18, pl. 5, ligs. 1 - z.

- lata, Reevk, Conchol. icon., X, Avicula, Sp. 5.

Between Koh Mesan and Cape Liant, 5-9 fathoms (1).

Long. $32 \mathrm{~mm}$., alt. $24 \mathrm{~mm}$.

Distribution:- Moluccas, Torres Strait.

Professor ED. v. MARTENS, to whom I sent the specimen for comparison, writes to me as follows: "wahrscheinlich lata Reeve, nur die Form des Ohrs passt nicht recht." 
Pteria (Electroma) zebra, Reeve.

(1). II, Figs. $16-18$ ).

Avicula zebra, ReEve, Conchol. icon., X. Avicula, Sp. 36.

Mantivi u. Chemerz, Conchyl. Cabin., VII, 3 Abth., p. 60, pl. 21, fig. 3.

Koh Kram, 30 fathoms (2). Koh Mesan, 15 fathoms, stones (2). Belween Koh Mesan and Koh Chuen, 25-38 fathoms, stones (6).

Loug. 3-12 $\mathrm{mm}$.

Distribution: - N. Male Atoll (EDg. Smith). - Gulf of Manaar (Standen \& Ineicester), 'Tuticorin ('Thurston), Port Elizabeth (Sowerby), l'ort Denison, Queensland ("Alert"), Moreton Bay, Australia (Cumng), King Island, Tasmania (T'Ate d May).

A variety, with twelve pale-brown lines radiating from the umbo, (without the characteristic oblique lines) was taken, to the number of three specimens in 30 fathoms at Koh Chuen; it was not found attached to any object as was the lype form. - The specimens, from the localities mentioned above, were all found attached to Plumularia sp. As may be seen from the figures in Pl. II, Figs. 16-18, the mimicry is excedingly striking; the beatiful colour-ornamentation upon the valves resembles exactly the branches of the Hydroid. REEve describes and figures it as attaclied to a Sertularia. 'TuUnsToN ${ }^{1}$ also mentions its mimicry in relation to Aglaophenia urens upon which it settles. G. J. AlLMaN mentions in the Report on the Hydroids of the Challenger Expedition, ${ }^{2}$ when treating of Plumularia abietina, that "The specimen had numerous individuals of an Avicula-like fry adhering to it." Judging from the figure it can, however, scarcely be A. zebra, Reeve.

Pteria pulchella, Reeve.

Avicula pulchella, ReEve, Conchol. icon., X, 1857, Avicula, Sp.22.

Martini u. Chemeitz, Conchyl. Cabin., VII Bd. 3 Abth., p. 42, pl. 13, fig. 6.

East of Cape Liant, 9 fathoms, shells (1).

Long. $20 \mathrm{~mm}$, alt. $16 \mathrm{~mm}$.

Distribution: - Philippines, East and South Australia.

On account of the small size of the specimen, there may perhaps be a slight doubt concerning the correctness of the determination.

Pteria (Margaritifera) vulgaris, Schum.

P'erlamaler vulguris, Scmumacmen, Essai d'un nouv, syst. d. habitat. d. vers test., 1817, p. 108, pl. 20, fig. 3. Margarilifera JAMison, Proc. Zool. Soc, Lond., 1901, I, p. 384 , Sp. 13.

W. A. Hendiax, Report on the Pearl Oyster Fisheries of the Gulf of Manaar, II, 1904, [j]. 37-76, pl. 1-9.

Avicula fucala, Gould, Proc. of the Boston Soc. of Nat. Hist., III, 1850, p. 309.

- - - Un. St. Expl. Exped. Moll., p. 4t1, pl. 39, fig. 551.

- - - Rervis, Conchol, icon., X, Avicula, Sp. 74 (pl. XVII).

1 Madras Goverument Museum, Bulletin No. 3, Humésvaram Island and Fauna of the Gulf of Manaar, "2 ed., Madras 1895, , p. 130.

2 Zoology, vol. 7,1883, p. 21, pl. 3. The specimen was from Prince Ldward's Island, 150 fathoms ("). 
Commonly distributed between Koh Rin and Koh Kong. 1-30 fathoms, mud, sand, gravel, shells and stones. The specimens gathered were almost all young individuals.

Long. 10-38 mm., alt. $10-32 \mathrm{~mm}$.

Distribution:- Malacca, Singapore, Madras, Ceylon, Palk's Strail, Gulf of Manaar, ${ }^{1}$ Maldives, Persian Gulf, Gulf of Aden, Red Sea, Suez (since the opening of the Suez Canal this species has wandered into the Mediterranean. There are typical examples from Alexandria and Malta in the British Museum. ${ }^{2}$ ), Mauritius, Bazaruto Isl., Durban. - Philippines, Japan (?), Flores, Sandwich Isls., Torres Strait, North Australia, East Australia (as far as Sydney), West Australia (as far as Sharks Bay), New Guinea, New Zealand (Gould).

I have followed H. L. JAMESON (l. c.) in his opinion regarding $P$. vulgaris, Schum., although I feel convinced that several of the species in his "Section c" are nothing else but varieties of this species. Schumacher's original specimen is in the Zoological Museum of the University of Copenhagen, and I can only confirm Jameson's opinion that $P$. vulgaris, Schum, is identical with $P$. fucala, Gould. $P$. vulgaris, Schum., has had numerous names given to it, owing to its variability in shape and colour. Thus A. H. CookE ${ }^{3}$ enumerates the following of REEvE'S species as identical (the original specimens in the "British Museum" were at his disposal): - imbricata, muricata, lentiginosa, occa, fimbriata, anomioides, aerala, irradians, and nebulosa, Conr. JAMESON (who has had the same specimens for examination) gives:- occa, Reeve, aerata, Reeve, perviridis, Reeve, varia, Dunker, and badia, Dunker, as synonyms of P. vulgaris, Schum. G. B. Sowerby believes that Avicula flabellum, Reeve, 5 and $A$. lacunata, Reeve, may be added to these. A. Martensi, Dunker, ${ }^{6}$ is also, no doubt, nothing but a form of the present species. G. F. Angas ${ }^{i}$ considers A. placunoides, Reeve, a variety of fimbriata, Reeve.

1 For details comp. L. G. Seurar, l'Huître perlière. Paris 1901. - E. IM Thurn, Sketch of the Ceylon Pearl Fishery of 1903. (Spolia Ceylanica, I. Colombo 1903). - J. Honnel., The Biolog. Results of the Ceylon Pearl Fishery of 1904. (Reports from the Ceylon Marine Biological Laboratory No. 1. Colombo 1905. - J. Calcotr Gasin (Proc. Zool. Soc. London, 1906, p. 803), A Memorandum on the Pearlshells in the Persian Gulf, - Eng. Thunston, Notes on the Pearl and Chank Fisheries and Marine Fauna of the Gulf of Manar, Madras 1890. - Report on the Pearl Oyster Fisheries of the Gulf of Manaar, by W. A. Hendax. 1-5. London 1903-6. - P. vulgaris, Schum, is fished here on a large scale for the sake of the pearls.

2 H. L. Jaseson (1. c. p. 385) and VASsel, Sur la Pintadine du Golfe de Gabes (Comptes-rendus. Assoc. franç. p. l'avancem. d. sc., 1896 , pp. $458-66$ ).

3 The Annals and Magaz. of Nat. Hist., vol. XVIl, 1886, pp. $136-37$.

* Appendix to Marine shells of South Africa, Lond. 1897, p. 27.

5 This is a form from Venezuela and A. H. CookE says (1. c. p. 137) that the type in the British Museum differs from A. fucata, Gould.

is Index molluscor. mar. Japon. Cassel 1882, p. 229, pl. 10, figs. 7-8.

‘ Proc. Zool. Soc. London, 1867, p. 930. 
Pteria (Margaritifera) vulgaris, Schum. var. occa, Reere.

Aviculu occa, Risevis, Conchol. icon.. X, 1857, Avicula, Sp. 24,

(Meleagrina) occa, Reeve, Martini u. Chematz, Conchyl. Cabin., Vil 13d. 3 Abth., p. 42, pl. 13, fig. 5.

Koh Kram, 30 fathoms (1/2).

Long. $28 \mathrm{~mm}$., alt. $29 \mathrm{~mm}$.

Distribution: - Red Sea, Gulf of Aden (Joussenume).

Professor ED. v. MARTENS, to whom I sent the specimen for comparison, writes to me as follows: "vermuthlich occa Reeve, wenn man annehmen kann, dass bei der Ihrigen die Schuppen abgerieben seien." A. H. CoOKE ${ }^{1}$ and H. L. JAMESON are certainly right in considering $A$. occa, Reeve, a form of Marg. vulgaris, Schmm. (= A. fucata, Gould). ${ }^{3}$ The present species has probably a far wider distribution Hhan that stated above, but to ascertain this, further investigations will be necessary. A. Grant lias collecled what he believes to be its synonyms, and according $10^{\circ}$ these its geographical distribution becomes considerably wider.

\section{Pteria (Margaritifera) nigra, Gould.}

Avicule nigra, Gouln, Proc. of the Boston Soc. of Nat. Hist., vol. 3, 1850, p. 305.

- - - Un. St. Expl. Exped. Moll., 1).438, pl. 40, fig. 45.

- tristis, Dunish, Mantivi u. Chemsitz, Conchyl. Cabiu., VII, 3 Abth., p. 44. pl. 14, fig. 3.

East of Koh Chuen, 9-10 fathoms, shells.

Long. $48 \mathrm{~mm}$., alt. $38 \mathrm{~mm}$.

Distribution: — Singapore.

A smaller specimen (long. $19 \mathrm{~mm}$, alt. $16 \mathrm{~mm}$.), which, with some doubt, I refer to the present species, was taken at Koh Kahdat in one fathom, on a sandy bottom.

\section{Pteria (Margaritifera) citrina, Dunk.}

Avicula (Meleagrina) cilrina, Dunken, Zeitschr. f. Malakozoologie, IX, 1852, p. 78.

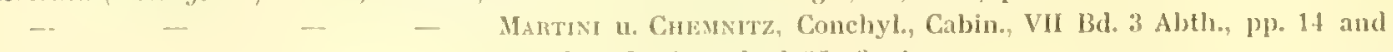
71 , pl. 3, fig. 4 , and pl. 25, tig. 1.

Pleria (Margaritifera) - _ _ JAsEsox, Proc. Zool. Soc. London, 1901, p. 383.

Strand of Koh Kahdat ( $1 / 2)$.

Long. $24 \mathrm{~mm}$., alt. $25 \mathrm{~mm}$.

Distribution:- Dutch India (E. v. Martens in litt.).

1 Anmals and Magaz. Nat. Hist., Ser. 5, vol. 17, pp. 136-37.

2 Proc. Zool. Soc. London, 1901, p. 384.

A. Pagristecher describes various forms of $P$. occa, Recve, from the Red Sea in "Ueber dic v. R. Kossmann am Rothen Meere gesamm. Mollusken," 1877, p. 35.

' Comptes rendus hebdomad. d. seances de la Soc. de I3iologie, Paris, Tome 56, 1904, 191. 255 -57. 


\section{Malleus figuratus, Chemn.}

Ostrea figurata, Chemsitz (Anas domestica Spengleri), Conchyl. Cabin., VIII, 1785, p. 17, pl. 70, fig. 658; pl. 71, fig. 659.

- anatina, Gmelin, Syst. Nat., ed. XIII, p. 3333, No. 101.

Malleus anatinus, LaMarcr, Anim.s. vert, éd. 2, VII, p. 93.

REEve, Conchol. icon., XI, Malleus, Sp. 3.

- - Gmelin, Martini u. Chemnitz, Conchyl. Cabin., Vili, 1 Abth., p. 8, pl. 2, fig. 4, and pl. 3, fig. 1.

- - - P. Fischer, Catal, d. Moll. de l'Indo-Chine, p. 210.

Koh Kram, 30 fathoms ( 1 specimen, long. $3 \mathrm{~mm}$.). E. of Cape Liant, 9 fathoms, shells (1). The northern side of Koh Mesan, 10--15 fathoms, stones (3). Between Koh Mesan and Koh Chuen, 25-38 fathoms, stones with shells (1 specimen, long. $7 \mathrm{~mm}$.).

Long. 3-16 $\mathrm{mm}$., alt. 5-53 $\mathrm{mm}$.

Distribution:- Nicobars, Kolumadulu Atoll (Maldive Archip.). -- Poulo Condor, Java, Timor, Moluccas.

\section{Malleus albus (Chemn.), Lam.}

Oslrea Malleus albus, Ciremntz, Conchyl. Cabin., XI, 1795, p. 257, pl. 206, ligs. 2029-30.

Halleus albus, Lamarck, Hist. nat. d. anim. s. vert., VI, 1819, p. 144, No.1. - 2 éd., VII, p.91, No. 1.

- - - Reeve, Conchol. icon., XI, Malleus, Sp. 1.

- - - Martini u. Chemnitz, Conchyl. Cabin., Vili, 1 Abth., 1. 4, pl. 1, figs. 1-2.

- Crosse \& Fischer, Journ. de Conchyl., vol. 40, 1892, p. 75.

- - - Pritchard \& Gateiff, Proc. Roy. Soc. Victoria, vol. 17, pl. 1, p. 258.

Between Koh Rin and Cliff Rock, 15 fathoms (2). Koh Chuen, 30 lathoms (1).

S. of Koh Kahdat, 8-10 fathoms, mud ( $1 / 2)$.

Gulf of Siam, west coast of Cambodge (Crosse \& Fischer).

Alt. $2-58 \mathrm{~mm}$.

Distribution: - Singapore, Ceylon, Gulf of Aden. - Philippines, China, Japan; north, east, and south coast of Australia.

\section{Malleus regula, Forsk.}

Ostrea regula, Fonskît, Descript. animal, qua in itinere orient. observ., 1775. p. 124.

Mulleus - - Savgny, Descript. de l'Égypte. Coquilles, pl. 13, figs. 1-4.

-- ReEve. Conchol. icon., XI, Mallers, $\mathrm{Sp} .4$.

- - Pagenstecher, Ueber die von Kossmann am Rothen Meere gesamm. Molluslien, 1877, p. 31, pl. 1, figs. 17-19.

- - - Issel, Malacol. d. Mar Rosso, 1869, p. 97.

Ostrea Folsella, Chemnixz, Conchyl. Cabin., VIII, 1785, p. 15, pl. 70, fig. 657.

Gmelin, Syst. Nat., ed. XIII, p. 3333, No. 100.

Malleus vulsellatus, Lamarck, Anim. s. vert., éd. 2, VII, p. 92.

Martini u. Chemnitz, Conchyl. Cahin., Vili, 1 Ahth., p. 7, pl. 2, fig. 3.

var. decurtatus, Lam.

Malleus decurtatus, LAMarck, Anim. s. vert., éd. 2, VII, p. 93.

\footnotetext{
- $\quad$ - $\quad$ - Revve, Conchol. icon., XI, Malleus, Sp. 10.

ligrinus, ReEve, Conchol. icon., XI, Malleus, Sp. 7.

D. K. D. Vldensk. Selsk, Skr., 7. 1t:ekke, naturvislensk. og mathem. Afd. V. 3. 
E. of Koh Chuen, 9-10 fathoms, shells (1). Koh Kahdat, 1 fathom, sand (1 abnormal specimen). Koh Kram, 30 fathoms (1 specimen, alt. $11 \mathrm{~mm}$.).

Long. $19 \mathrm{~mm}$., alt. $31 \mathrm{~mm}$.

Distribution: - Persian Gulf, Gulf of Aden, Red Sea, Suez, Ascension Isl. (Edg. A. Smrn). - Philippines, Japan, Timor, Moluccas; North-west and South Australia.

The specimen from Koh Chuen belongs to var. decurtatus, Lam., while the specimens from Koh Kahdat and Koh Kram must be referred more especially to M. regula, Forsk. A single valve (long. $13 \mathrm{~mm}$., alt. $15 \mathrm{~mm}$.) was taken between Koh Kut and Koh Kahdat (in about 10 fathons, on a shelly bottom); this must undoubtedly be referred to var. decurtatus, Lam.

\section{Perna vespertilio, Reeve.}

Perna vespertilio, Refve, Conchol. icon., XI, Perna, Sp. 26.

- - - Martini u. Chemnitz, Conchyl. Cabin., VIII, 1 Abth., p. 37, pl. 13, fig. 2.

Kolı Kram, 30 fathoms (1/2).

Long. $53 \mathrm{~mm}$., alt. $55 \mathrm{~mm}$.

Distribution:- Philippines.

As far as I can judge from the scanty material at my disposal, this species varies exceedingly, and if a number of specimens could be obtained for comparison from the same district, several forms, which are now regarded as distinct species, would undoubledly be reduced to synonyms; indeed perhaps it would be necessary to refer the whole "species" to another form.

\section{Perna Spengleri, Chemn.}

Siliqua Spengleri, Cinemnitz, Conchyl. Cabin., VII, 1784, p. 250, pl. 59, fig. 578.

Ostrea Legumen, GMein, Syst. Nat., ed. XIII, p. 3339, No. 128.

Perna dactylus, Valenciennes, Encycl. méthod., pl. 175, figs. 2-3.

- legumen, GMelin, ReEve, Conchol. icon., XI, Perna, Sp. 22.

- linguaeformis, - _ - Sp. 7.

- laticostala, $\quad$ - $\quad$ - $\quad$ - Sp. 9.

- caulala, - - - - S 5.

- Reeve, A. H. Cooke, Ann. \& Mag. Nat. Hist., XVII, 5 Ser., 1896, p. 138.

Common at Kolı Chang, Koh Lom and Koh Kahdat, 1-12 fathoms, sand and old coral blocks.

Long. 4-12, alt. $5-26 \mathrm{~mm}$.

Distribution: - Mergui Archip., Nicobars, Red Sea, Lifu Isls., Society Isls.

I have re-introduced Chemsitz's name, which, strangely enough, in spite of its priority, has hitherto been disregarded. The original specimen figured by CuEmitz (besides a smaller one from SPENGLEr's collection), is in the Zoological Museum of the University of Copenhagen. It is somewhat worn and deformed, but nevertheless agrees entirely with GMELIN's $P$.legumen. The deep-blue spots at the beaks menlioned by Cummitz, are due to the fact, that the valves of his specimen, when 
young, were dark-coloured, quite an individual character. In the new edition of "Martini \& Chemeitz, Conchyl. Cabinet," Clessin has worked out the genus Perna, but nowhere does he mention Cinemitz's P. Spengleri.

\section{Perna isognomon, L.}

Ostrea isognomon, LivNé, Syst. Nat., ed. X, 1758, 1). 699, No. 176. - ed. X11, p. 1149. - Mus. Luelov. Ulr., p. 533 , No. 120 .

Melina Isogonum, - Merzus, Nova 'lestaceor. Gen., 1788, p. 23.

Ostrea isognomon, - Guelin, Syst. Nat., ed. XIII, p 3338, No. 125.

Perna isognomum, - ReEve, Conchol. icon., XI, Perna, Sp. 24.

- isogonum, - Clessin in Martini u. Chemniz, Conchyl. Cabin., Vill, 1 Abtlı., pl. 8, fig. 1.

Last of Koh Chuen, 9-10 fathoms, shells (2).

D istribution:- Singapore, Mergui Archip., Madras, Madagascar and Mozambique, Mauritius. - Poulo Condor, Philippines, Amboina, Moluceas, Sorong, New Guinea, Thursday Isl.

Of the two specimens brought home from the above-mentioned locality the larger (long. $59 \mathrm{~mm}$, alt. $99 \mathrm{~mm}$.) should be referred to the variety femoralis, Lam.," and the smaller (long. $34 \mathrm{~mm}$, alt. $73 \mathrm{~mm}$.) to the variety curvata, Ch.

\section{Perna rudis, Reeve.}

Perna rudis, ReEve, Conchol. icon., XI, Perna, Sp. 20.

- - - Martini u. Chinitz, Conchyl. Cabin., Vili, 1 Abth., p. 31, pl. 9, fig. 6.

North end of Koh Chang, 1 fathom, old coral blocks (1). Koh Kaludat, 1 fathom, sand (3).

Alt. 14- $98 \mathrm{~mm}$.

Distribution:- Jousseaumet records that one specimen of this species was taken at Obock (Gulf of Aden). Collected by Voectzkow at Zanzibar.

The present species is closely allied to $P$. isognomon L. A. H. Cooke ${ }^{5}$ thinks that P.rudis, Reeve, is synonymous with P. legumen, Gmel. (= linguaeformis, Reeve $=$ laticostata, Reeve = caudala, Reeve).

\section{Perna Cumingi, Recve.}

Perna Cumingii, ReEve, Conchol. icon., XI, Perna, Sp. 3.

Cumingi, - Mantini u. Chemnitz, Conchyl. Cabin., VIII, 1 Abth., p. 40, pl. 15, fig. 1.

Melina cumingii, - Evg. Smith, Zoolog. Collect. of H. M. S. "Alert," p.113.

1 The extremely unsatisfactory and unscientific way in which this has been done is much to be regretted. As an example of the superficiality which characterises the work may be mentioned that one of the best-known species, $P$. isognomon L., is called $P$. isogonum L. throughout the whole work.

2 Hist. nat. d. anim. s. vert., 2 éd., VII, p. 76, No. 5.

${ }^{3}$ Cheminz, Conchyl. Cabin., VII, 1784, p. 256, pl. 59 , fig. 583.

* Mém. de la Soc. zoolog. de France, I, 1888, p. 219.

'Annals and Magaz of Nat. Hist, 5 Ser., vol. 17, p. 138. 
The Gulf of Klong Salakpat (soulh end of Koh Chang); many specimens; occurred in large lumps, attached to each other by their byssus-threads.

As the relation between the height and the breadth varies greally in the different individuals, I give here the measurements of 3 different specimens: long. $96 \mathrm{~mm}$, alt. $75 \mathrm{~mm}$. - long. $92 \mathrm{~mm}$, alt. $105 \mathrm{~mm}$. - long. $4 \mathrm{~mm}$., alt. $5 \mathrm{~mm}$.

Distribution:- Annam (Dautzenizerg), Australia (Reeve), Port Curtis ("Alert"). "P. ephippium L." has been recorded from the following localities:- Singapore, Mergui Archip., Nicobars, Mozambique and Madagascar, Mauritius. - Celebes, Philippines, Sorong (Taprarone Canefri), Port Curtis (East Australia), West Australia.

The West-Indian species $P$. alata, Gmel., bears much resemblance to $P$. Cumingi, Reeve; they may, however, be distinguished from each other by the radiating lines in the latter species, which give the growth-margins a crenulated appearance. But what is to become of $P$. ephippium L., if these two species are maintained?

\section{Perna nucleus, Lam.}

Perna nucleus, Lamarck, Hist. nat. d. anim. s. vert., éd. 2, VII, 1836, \%. 78, No. 10.

- - - L Reve, Conchol. icon., Xl, Perna, Sp. 4.

- - Reeve, Martixi u. Chemnitz, Conchyl. Cabin., VIli, 1 Abth., p. 36, pl. 13, lig. 1.

Melina - Lamarck, Lamy, Bull. Mus. d'Hist. Nat. I'aris, 1906, p. 314, No. 70.

Perna pectinata, REEve, Conchol. icon., Xl, P'erna, Sp. 2.

- quadrangularis, REEve, loc. cit., Sp.6.

Koh Lom, W. of Koh Chang (many specimens).

1) Long. $10 \mathrm{~mm}$, alt. $14 \mathrm{~mm}$. 2) Long. et alt. $9 \mathrm{~mm}$. 3) Long. $7 \mathrm{~mm}$., alt. (9) $\mathrm{mm}$.

D istribution:- Mergui Archip., Red Sea, Suez, (Natal and Bourbon, P.dentifera, Krauss). - Poulo Condor, Philippines, Samoa Isls, Fiji Isls., New Holland (Lamarck).

This species is highly variable, as are all the forms belonging to this group. A. H. Cooke has enumerated the following species, which he believes to be identical with the present one: - P. nana, Gould, $P$. rostrata, Schum., P. lobata, Recve, $P$. spathulata, Reeve, P.dentifera, Kirauss.

\section{Pinna inflata, Chemn.}

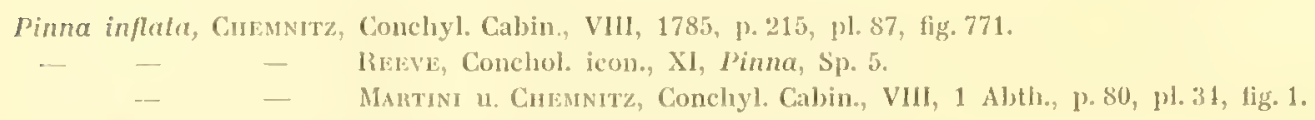

W. of Koh Cliang, 20 fathoms, mud (1).

Long. $136 \mathrm{~mm}$, all. $82 \mathrm{~mm}$.

Distribution:- Nicobars, Ceylon. - Philippines.

Pinna hystrix, Hanl.

Pinne Mystrix, Haxley, Proc. Zool. Soc. London, XXVI, 1858, p. 226.

- - - Reevi, Conchol. icon., XI, Pinna, figs.60-61 (and the register).

1 Annals and Magaz. of Nat. Hist, 5 Ser., vol. 17, 1886, 13. 138. 
Koh Chuen, 30 fathoms (3).

1) Long. $172 \mathrm{~mm}$, alt. $112 \mathrm{~mm}$. 2) Long. $183 \mathrm{~mm}$, alt. $112 \mathrm{~mm}$.

Distribution:- Gulf of Suez, Red Sta. - Amboina, Australia.

Pinna Strangei, Hanl., is undoubtedly only a form of the present species without scales upon the ribs. L. MorLet" records Pinna Chemnitzi, Hanl., from "the islands in the Gulf of Siam;" can this be due to erroneous determination? The Danish Expedition, at any rate, did not bring home any specimen of this species. Clessin, in his Monograph of the genus Pinno, in "Martini and Chemnitz, Conchylien Cabinet," figures and describes quite another species under the name of $P$. Strangei, Hanl. PAgenstecher " records $P$. hystrix-forms from the Red Sea, and also forms having ribs without scales (from the same locality), which he names P. atropurpurea, Sow.

Pinna attenuata, Reeve.

Pinna allenuala, ReEve, Conchol. icon., XI, I'inna, 1858, Sp. 46.

- - Menke, Martini u. Chemnitz, Conchyl. Cabin., VIII, 1 Abth., p. 59, pl. 27, fig. 1.

- Stulchburii, ReEve, Conchol. icon., XI, Pinna, 1859, Sp.64.

Martini u. Chemnitz, Conchyl. Cabin., Vili, 1 Abth., p. 74, pl. 30, fig. 2.

Off T'ung Kaben, 6 fathoms, mud mixed with sand (1).

Long. $173 \mathrm{~mm}$., alt. $51 \mathrm{~mm}$.

Distribution:- Madras, Gulf of Manaar, Gulf of Suez, Red Sea. - Moluccas, Moreton Bay (Australia).

The specimen from the Gulf of Siam bears a few scales on some of the raised, longitudinal ribs; this is also found often to be the case in specimens from the Red Sea." I have given P. Stutchburyi, Reeve, as a synonym, as I cannot see any difference, worthy of mention, between these two forms. ${ }^{1}$

Pinna mutica, Reeve.

Pinna mutica, ReEve, Conchol. icon., XI, Pinna, 1858, Sp. 33.

- - - Martini u. Chemeitz, Conchyl. Cabin., Vili, 1 Abtli., p. 6\$, pl. 20, fig. 2

Koh Chuen, 30 fathoms (1). Koh Kram, 30 fathoms (1 young specimen).

Long. 38-147 mm., alt. $13-63 \mathrm{~mm}$.

Distribution:- Philippines.

Pinna madida, Reeve, P. cuglypta. Hanl., and $P$. vespertina, Reeve, show great resemblance to the present species, and will perhaps prove to be synonyms of $I$. mutica, Reeve.

Pinna serra, Reeve.

Pinna serra, ReEve, Conchol. icon.. XI, 1858, Pinna, Sp. 43.

- - - Clessin in Martixi u. Chemnitz, Conchyl. Cabin., Vhil, 1 Abth., 1891, p. 60, pl.28, fig. 2.

1 Journal de Conchyliologie, vol. 37, 1889, p. 161.

- Ueber die von Kossmann am Rothen Meere gesamm. Mollusken. Lpzg. 1877, p. 30.

For details concerning this and the variation, etc of P. Stutchburyi comp. PAGENSTLCHER, Ueber die von Kossmann am Rothen Meere gesamm. Mollusken. Leipz. 1877, pp. 30-31.

* Professor ED. v. Martens says in a letter to me, that these two forms: "sind einander sehl" ähnlich und gehören vielleicht beide zu Einer Art." 
East of Koh Chuen, 9-10 fathoms, shells (2).

Long. $30 \mathrm{~mm}$.

Distribution: - Aden (EDg. Syith), Durban (Soweriz). - Morelon Bay, Queensland (REEve).

Note. In Pl. II, Figs. 19-20, I have given figures of a young specimen of Pinna sp. (taken between Kol Kut and Koh Kahdat, in 10 fathoms; $18 \mathrm{~mm}$. long) with a very well-preserved prodissoconch, which is distinctly separated from, and highly different from the later increment to the valve. (R.'T.JAckson says in "Phylogeny" of the Pelecypoda," Boston 1890, p. 332, when mentioning the group Perna, Avicula, and their near allies: "The genera Malleus and Pinna might be considered in this section, but I have not succeeded in getting very young specimens of either genus," and later on, p. 385, "I have not had opportunity to study the Pinnide satisfactorily as attempts to obtain very young specimens have so far failed;" in the specimen of a young Pinna sp. figured in his Fig. 53 the prodissoconch is also wanting). P'ELSENEER, ${ }^{1}$ in his "System," places the genus Pinna under the order Eulamellibranchia, near to Ostrea and Lima, while Avicula (Pteria) is found under the order Filibranchia. F. BERnARD, who has later examined the development of the shell of the gen. Pinna, has reached another opinion, though the material at his disposal, as he says, has been very small. The result of his researches is, that the gen. Pinna belongs to Mytilidae. The scanty material at my disposal prevents me from entering more fully into the question.

\section{Fam. Spondylidae.}

\section{Spondylus Sinensis, Sow.}

Spondylus Sinensis, Sowkiby, Thesaurus Conchyliorum, 1, 1847, p.427, pl. 87, figs. 32-34. HeEve, Conchol, icon., IX, 1856, Spondylus, Sp. 7.

S. of Koh Chuen, 30 fathoms, shells (1). West coast of Koh Chang, 10 fathoms, mud $(1+2 / 2)$. Between Koh Chuen and Koln Chang, 15 fathoms, mud (1/3). E, of Koh Mak, 20 fathoms, mud (1). Between Koh Kut and Koh Kahdat, 10 fathoms, shells $\left(1+{ }^{4} / 2\right)$. S. of Koh Kahdat, 8-10 fathoms, mud (1). W. of Koh Kut, 15 fithoms, mud (2).

Long. $3 \mathrm{~mm}$., alt. $35 \mathrm{~mm}$.

- $46 \mathrm{~mm} .,-56 \mathrm{~mm}$.

Distribution: - Poulo Condor, Cochin China, Annam, China, Japan.

The valves are quite white in one of the specimens from the Gulf of Siam."

Spondylus coccineus, Lam. (Reeve).

Spondylus coccineus, Lamarck, Hist. nat. d. anim. s. vert., VI, 1 part., 1819, p. 190, No. 11. - éd. 2, VII, 1836 , p. 188, No. 11.

- $\quad$ - $\quad$ L IREvis, Conchol. icon., IX, Spondylus, 1856, sp. 44.

- ocellatus, REEve, Conchol. icon., IX., Spondylus, Sp. 43.

1 A Treatise on Zoology, ed. by E. RaY Laviester, V, Mollusca by P. PELsexeen, Iondon 1906, p. 263.

"Recherches ontogén. et morphol. sur la coquille d. Lamellibranches. Annales d. sc. natur. Zoologie, VIII, Paris 1898 , pp. 45 et $85-86$.

3 Comp. Dunken, Index moll. mar. Japon., 1882, p. 215. 
Koh Chuen, 30 fathoms (on Pinna hystrix, Hanl.). Koh Mak, sandy coast (3/2). North end of Koh Chang, 1 fathom, old coral blocks; a very large specimen (long. $79 \mathrm{~mm}$., alt. $76 \mathrm{~mm}$., crass. $42 \mathrm{~mm}$.). Besides agreeing well with REEvE's figure of ocellatus it closely resembles his figure and description of Sp.spectrum, Reeve.

Long. $23 \mathrm{~mm}$., alt. $28 \mathrm{~mm}$.

- $13--13 \mathrm{~mm}$.

Distribution:- Singapore (2-3 fathoms, attached to coral reefs; Danish Exp. to Sian), Mauritius and Cargados (coccineus, Lam.). - Amboina and Flores (coccineus, Reeve), Philippines (ocellatus, Reeve, and coccineus, Reeve), Torres Strait (ocellatus, Reeve), Lifu (ocellatus, Reeve).

The specimen taken at Singapore (long. $18 \mathrm{~mm}$., alt. $23 \mathrm{~mm}$.) entirely agrees with Sp.plurispinosus, Reeve (v. Martens records this species from the Mergui Archipelago); in this specimen, and also in the young specimen from Koh Chuen, the somewhat flattened spines are furnished with a row of small teeth along cach of the two sides; these teeth are visible, however, only under the lens, and is found, undoubtedly, only in quite young specimens.

Spondylus maculatus, Chemn., is very closely allied to the present species (I have had Chemnitz's original specimen for examination), but as the original specimen is rather worn, no definite conclusion can be drawn at present. It is doublful whether REEVE's coccineus is identical with LAMARck's species of the same name. v. Martens ${ }^{1}$ states that coccineus, Reeve, is identical with Spondylus zonalis, Lam. (For further details see S. spectrum, Reeve).

\section{Spondylus spectrum, Reeve.}

Spondylus spectrum, ReEve, Conchol. icon., IX, 1856, Spondylus, Sp. 49.

- fragum, ReEve, Conchol. icon., IX, 1856, Spondylus, Sp, 61.

East of Koh Chuer, 9--10 fathoms, shells (1/2).

Long. $38 \mathrm{~mm}$., alt. $43 \mathrm{~mm}$.

Distribution:- Poulo Condor, Philippines.

After having examined ReEve's original specimens in the British Museum, I have put $S$. spectrum $=S$. fragum. Without doubt several others are synonymous with these spccies, for instance, camurus, Reeve, castus, Reeve, and others; and perhaps it will be proved, when these highly variable forms have been more closely examined, that the numerous species from the Philippines and the surrounding waters (for instance, S. mus, Reeve, S. tenuispinosus, Sow., S. ducalis, Ch., S.zonalis, Lam., S. virgineus, Reeve, S. ocellatus, Reeve, S. coccineus, Lam., S. fragilis, Sow., S. Nicobaricus, Ch., S. aurantius, Lam., S. variegatus, Ch.. and others), in which the young valves are ornamented with dark dots and spots, but later on have a very different sculpture and colour-ormamentation, are only varieties of the same form. I have at my disposal, a very considerable quantity of material of the West Indian

1 Rumphius Gedenkboek, 1902, Die Mollusken, p. 128 (20). 
species S. spathuliferus, Lam., which presents an almost incredible variability concerning the colour-ornamentation, and the occurrence and arrangement of spines, spatulate scales, etc; but they may all be at once recognized by the characteristic colours and appearance of the young valve which is insensible to other influences. With such an example for consideration, I think it very probable that my supposition concerning the relationship between some of the East Indian forms, will prove to be right.

Spondylus Layardi, Reeve.

Spondylus Layardi, ReEve, Conchol. icon., IX, Spondylus, 1856, Sp. 66.

Strand of Koh Kahdat ( $1 / 2)$.

Long. $27 \mathrm{~mm}$., alt. $26 \mathrm{~mm}$.

Distribution:-- Ceylon (Cuming), Gulf of Manaar (Thunston, Standen \& LEICEISTER).

Plicatula imbricata, Menke.

Plicatula imbricata, Mnks, Molluscor. Novae Hollandiae specim., 1813, p. 35, No. 196.

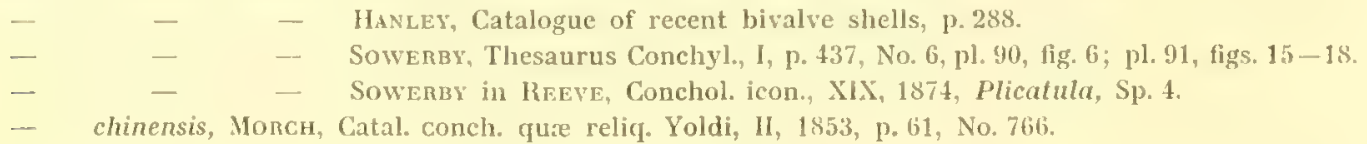

Between Koh Rin and Cliff Rock, 15 fathoms (2/2). Koh Kram, 30 fathoms (1). N. of Koh Kam, 5 fathoms, gravel (1/2). Off Koh Kam, 10 fathoms, gravel (1). North side of Kol Mesan, 10-15 fathoms, stones $(1+2 / 2)$. Between Koh Mesan and Cape Liant, 5-9 fathoms $(2 / 2)$. Between Koh Mesan and Koh Chuen, 25-38 fathoms, stones and shells (2). Koh Chuen, 10-30 fathoms $(1+\% / 2)$. E. of Koh Chuen, 9-10 fathoms, shells $\left({ }^{1 / 2}\right)$. S. of Koh Chuen, 30 fathoms, shells $(1+3 / 2)$. Gulf of Rayong, 7-10 fathoms, sand, mud, shells (2/2). North end of Koh Chang, 1 fathom, old coral blocks ( $\left.{ }^{1 / 2}\right)$. Between Koh Kut and Koh Kahdat, 10 fathoms, shells (2).

Long. $7 \mathrm{~mm}$., alt. $8 \mathrm{~mm}$. - long. $28 \mathrm{~mm}$., alt. $33 \mathrm{~mm}$.

Distribution:- Singapore (Danish Exp. to Siam, and Sv.Gad), Andamans (Melvill \& Sykes), Aden (Shopland), Gulf of Tadjourah (Gravier, Anthony), Ile Cameran, subfossil (Jousseaume), Mascarenes (v. Martens). - China (Hanley), Philippines (Soweriby), Amboina? (Edg. Smith), Tortes Strait (Melvil \& Standen), West Australia (Menie, Handey), Port Jackson and Port Stephens (Angas), Funafuti Aloll? (Hedley). (Sowerby records it also from Honduras Bay).

The species belonging to the genus Plicalula, owing to their great variability, are exceedingly difficult to define and to characterize. Hence, numerous species have been established which cannot be maintained and many erroneous determinations lrave been made, which have resulted in the records of the geographical distribution of the species frequently becoming quite misleading. Thus $P l$ spondyloidea, Meusch. ( = Pl. ramosa, Lam.), ${ }^{2}$ has been recorded, e. g. from: Aden (Jousseaume),

${ }^{1}$ M. spondyloidea, Meusch. $=$ Pl. ramosa, Lam. = Barbadensis (Petiv.), d'Orb. $=$ plicala, Chemn. = cristata, Lam. = reniformis, Lam. = gibbosa, (Lam.) Sow. = marginala, Say. 
the Red Sea (Sturany, Pagenstecner, and others), Sucz (Varluant), Mauritius (v. Martens), Mozambique (Petirs), Querimba Isl. (v. Mantens), Poulo Condor? (Rocherrune, P. reniformis, Lam.), China (Mrthell), Lord Hood's Isl. (Sowerby), and also from the east coast of North, Central, and South America, from Cape Hatteras to Patagonia (D'Orbigny, Morch, Krebs, Sowerisy, Adams, Pagenstecher, Dall, Edg. Smith, BEAU, and others). - It will tloubtless be proved later, that several of the species closely allied to $P$. imbricata, Mke, are synonymous with it, $\mathrm{c}$. g. $P$. depressa, Lam. (from Singapore and Mergui İsl., v. Martens ${ }^{1}$ ), P. Novae Zelandiae, Sow. (New Zealand), P'. Essingtonensis, Sow. (Port Essington), P. Philippinurum, Hanl. (Philippines, Sowerby; Red Sea, Cooke; Hong-kong, Fravenfeld). P. Ceylanica, Sow. (Ceylon), P. Australis, Lam. ${ }^{2}$ (Philippines, Hanlex; Australia, Lamarck, Hedrex), P. horrida, Dunk. (Japan and China, Duyker), P. aculeata, Sow, and others. Among the specimens from the Gulf of Siam several individuals occur, which agree both with the figure given by REEvE (Pl. 1, Fig. 4c) and that by Sowerur (Pl. 90, Fig. 6), they bear a very close resemblance to corresponding individuals of P. spondyloidea, Meusch., from St.'Thomas.

\section{Fam. Pectinidae.}

\section{Pecten pyxidatus, Born.}

Ostrea pyxidata, I3onN, Testacea Musei Cresarei Vindobon., 1780, p. 108, pl. 6, figs.5-6.

Pecten pyxidalus, - ReEve, Conchol. icon., VIII, Pecten, Sp. 96.

- - - Martini u. Chemnitz, Conchyl. Cabin., ViI, 2 Abth., p. 57, pl. 15, figs. 5-1;; pl. 35, tigs. $1-2$.

- - - Fischer, Catalogue d. Moll. de l'Indo-Chine, p. 209.

- crebricostatus, Phulpp, Abbild. u. Beschreib. neuer od. wen. gekannt. Conchylien, I, p. 100 (2), pl. 1, tig. 2.

Common from Koh Lan to Koh Kut, 6-30 fathoms, mud and clay.

Gulf of Sian, west coast of Cambodja (Crosse \& Fiscrer).

Long. $8-36 \mathrm{~mm}$.

Distribution:- Singapore (2-3 fathoms, coral reef, Dr. Mortensen), Mergui Archip., Andamans, Tranquebar, Gulf of Manaar, Persian Gulf, Gulf of Oman.-Annam, China, Philippines.

Pecten senatorius, Chemn. (Gmel.).

Pallium senatoris, Chemvitz, Conchyl. Cabin., VII, p. 320, pl. 65, fig. 617.

Ostrea senuloria, Gmelı, Syst. Nat., ed. X111, 1790, p. 3327, No. 61.

Pecten senatorius, - REFve, Conchol, icon., VIII, Pecten, Sp. 81.

- - - Martini u. Chesnitz, Conchyl. Cabin., V1I, 2 Abth., pp. 63 and 83, pl. 16, fig. 7 ; pl. 21, fig. 4 .

- - - Evg. A. Smitr, Challenger Heport, Lamellibranchiata, 1885, p. 300.

${ }^{1}$ Lifnard records it from Mauritius, but v. Mantens considers it (in: Mollusken d. Maskarenen u. Seychellen, p. 137) to be "wahrscheinlich amerikanisch."

2 non P. Australis, lírauss (from Natal) $=$ multiplicala, Desh.

D. K. D. Vidensk, Selsk. Skr., 7. Rickke, naturvidensk. ug matls. Afil V. 3. 
Among the Pecten-species this was the one which was taken most frequently; from Koh Rin to Koh Kut in 5-38 fathoms, on a bottom of mud and shells.

Long. 4-67 $\mathrm{mm}$.

Distribution:-- As the question regarding the variations in form of the present species has not yet been quite settled, its distribution cannot be given with any cerlainty, but the following localities may doublless be regarded as certain:Salanga, Mergui Archip., Madras, Gulf of Manaar, Bombay, Karachi, Persian Gulf, Maldive Archip., Gulf of Aden, Red Sea, Gulf of Suez, Mauritius, Inhambane (SE. Alrica). - Philippines, China, Japan, I3litang (post-tertiary), Moluceas, Torres Strait, Mast Head Reel (Queensland), New Caledonia.

The considerable variations in form, to which the present species is subject, have caused that an enormous number of different names has been given to it. EDg. A. Smitr ${ }^{1}$ has enumeraled a large number of these forms, most of which can scarcely be regarded as varieties. 'The large quantity of material brought home from the Gulf of Siam shows plainly the variability of the species, both as regards sculpture and colour. The form porphyreus, Chemn." occurs most frequently; there are developed upon it, when the individuals have reached a certain size, smaller ribs on each side of the main ribs, which thereby become tripartite; the whole surface is closely covered with scale-sculpture; this form strongly recalls $P$. asperrimus, Lam. (P. australis, Sow.). I have compared Chemnitz's original specimen of P.porphyreus, which is in the Zoological Museum of the University of Copenhagen, with the specimens from the Gulf of Siam; they correspond in all respects with the latter. E. v. MarTens ${ }^{3}$ distinguishes, but scarcely correctly, between $P$. porphyrens, Chemn. (= P. senatorius, Reeve, non Chemn.), and P. senatorius, Chemn.; these forms cannot be kept distinct from each other, as transitional forms occur. In the Gulf of Siam are found specimens, some with quite smooth ribs, and others with strong scale-sculpture on all the'ribs. BaYaY thinks that P'. splendidulus, Reeve, belongs Io the variety-series of $P$. senalorius.

\title{
Pecten rugosus, Sow.
}

\author{
(Pl. 1II, Figs. 1-2).
}

Peclen rugosus, Sowrnuy, Thesaurus Conchyl., I, Peclen, p. 66, No.64, pl. 19, fig. 226.

REEvi, Conchol. icon., VIII, Pecten, Sp. 144.

- Maltixi u. Chemnitz, Conchyl. Cabin., VII, 2 Abth., p. 232, pl. 6il, fig. 3 ,

1 Koology of the voyage of H. M. S. Challenger. Report on the Lamellibranchiata, p. 300.

: I liave at my disposal several specimens from the Gulf of Siam which correspond exactly witi the figure in SAvigix, Iconographic d. Mollusques de l'Egypte, pl. 13, fig. 5, 2 of "Pecten australis, Sowerby' Issri, Malacol. d. Mar Rosso, p. 372). In my opinion this figure represents most closely a very wellpreserved individual of $l^{\text {' }}$. senatorius, Ch. var. porphyreus, Ch.

' Die Mollusken d. Maskarenen u. Seychellen, 1880, p. 138. - Journ, of the Linnean Soc, Zoology, vol. 21, 1887, p. 202. - Kumphius Gedenkboek, 1902. Mollusken, 1) 126 (18).

Bull. du Museum d'Hist. Nat. P'aris, 1904, p. 366. 
S. of Koh Chuen, 30 fathoms, sliells (1/2). From Koh Chuen to Koh Chang, 15 fathoms, mud ( $\left.{ }^{4} / 2\right)$. S. of Koh Bidang, 9 fathoms, shells ( $\left.{ }^{2} / 2\right)$. E. of Koll Mak, 20 fathoms, mud (2/2). Between Koh Kut and Koh Kahdat, 10 fathoms, shells (11/2). W. of Koh Kut, 15 fathoms, mud (b/2).

Long. 7-25 mm., alt. $8-26 \mathrm{~mm}$. (1 specimen long. $22 \mathrm{~mm}$, alt. $25 \mathrm{~mm}$.).

Distribution:- Philippines.

I am relying upon ED. v. MARTENs's identification, in referring these forms to $P$. rugosus, Sow.; as may be seen from my figures, the forms in question are very different from those of SowERBY (REEvE). In my specimens, the intercostal parts are not always smooth, but are often irregularly striated. EDG. SMrTh considers $P$. rugosus, Sow., to belong to a series of forms which will probably prove to be varieties of $P$. senatorius, Ch. Young specimens are in maný cases difficult to distinguish from the young of P. senatorius, Ch.

Pecten Singaporinus, Sow.

Pecten Singaporinus, Sowemur, Thesaurus Conch., I, p. 74, pl. 13, tigg. 55; pl. 14, fig. 71.

$\begin{array}{lll}- & - & \text { Reive, Conchol. icon., VII, Pecten, Sp. } 74 . \\ - & - & \text { Martini u. Chemsitz, Conchyl. Cabin., VII, } 2 \text { Abtli.. 1. 94, pl. 25, figs. } 2 \ldots 4 . \\ - & - & \text { P. Fischer, Catalogue d. Moll. de I'Indo-Chine, p. 209. }\end{array}$

The coast of Lem Ngob $(4 / 2)$.

Long. 23-48 mm., alt. $25-51 \mathrm{~mm}$.

Distribution:- Singapore, Madras, Gulf of Manaar, Bombay, Gulf of Aden. - Annam, Hong-kong, Port Curtis (East Australia).

Eog. A. Smitu ${ }^{1}$ considers P. pica, Reeve (from New Zealand), and P. Cumingii, Reeve (from Moreton Bay), to be identical with the present species. PILsisr, " has described from Japan an allied form, with fewer ribs, under the name of $P$ '. Aweijichsis.

\section{Pecten cretatus, Reeve.}

Pecten cretutus, REEvE, Conchol. icon., VIII, 1853, Pecten, Sp. 129.

- - - Mahtini u. Chemnitz, Conchyl. Cabin., VII, 2 Abth., p. 172, pl.47, tigs, 8-9.

North of Koh Kahdat, 4-5 fathoms, coarse sand (1/2). Between Kolı Kut and Koh Kahdat, 10 fathoms, shells $(1 / 2)$.

Long. $5-7 \mathrm{~mm}$. (long. $7 \mathrm{~mm}$, alt. $7 \mathrm{~mm}$.).

D) istribution unknown.

Pecten nux, Reeve.

Peclen nux, ReEve, Conchol. icon., V111, 1853, Sp. 143 (sec Sp. 149).

N. of Koh Kahdat, $4-5$ fathoms, coarse sand (1/2).

Long. $7 \mathrm{~mm}$, alt. $7 \mathrm{~mm}$.

" Report on the zoolog. collect. made during the voyage of H. M. S. "Alert." Lond, 1884, 1. 115.

2 Proc. Acad. Nat. Hist. Philadelphia, 1905, p. 121. 
Distribution:- Maldive Archip. (Evg. Smith). - Nukahiva, Marquesas Isl. (REEVE).

$P$. sugillatus, Reeve, is closely allied to the present species.

Note. Pecten hybridus, Gmel. (P. squamosus, Gmel.), was taken by the Danish Expedition at Singapore in $2-3$ fathoms, on coral-reefs.

\section{Pecten (Pallium) plica L.}

Ostrea plica, LinNí, Systema Nat., ed. X, 1758, p. 697, No. 162. — ed. X1I, p. 1145, No. 192. - Mus. Ludov, Ulr. Reg., p. 526, No. 106.

l'ecten - - Revve, Conchol. icon., VIII, Pecten, Sp. 16

- - - Martini u. Chemnitz, Conchyl. Cabin., ViI, 2 Abth., pp. 53 and 96, pl. 14, figs. 3-1; pl. 26 , fig. 4 .

- plicatus, Chemnitz, Conchyl. Cabin., VII, p. 292, pl. 62, tig. 598.

E. of Cape Liant, 9 fathoms, shells (1). S. of Koh Chuen, 30 fathoms, shells (2). Long. $41-42 \mathrm{~mm}$., alt. $44-46 \mathrm{~mm}$.

Distribution: - Nicobars, Ceylon and Gulf of Manaar, Persian Gulf, Gulf ol Oman, Maldive Archip., Gulf of Aden, Red Sea and Gulf of Suez. - China Sea, Japan (Nagasaki).

\section{Pecten subplicatus, Sow.}

Pecten subplicalus, Sowkisy, Thesaurus Conch., 1, 1812, p.64, pl. 13, fig. 37; pl. 14, figs. 72,73 and 81.

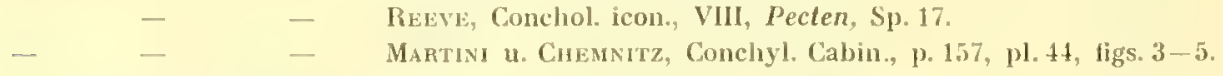

Koh Kram, 30 fathoms (1). North side of Koh Mesan, 10-15 fathoms, stones (1). 1 mile south of Koh Chuen, 30 fathoms, shells (1/2). Koh Kahdat, 1 fathom, sand (1/2). Between Koh Kut and Koh Kahdat, 10 fathoms, shells (1/2). N. of Koh Kut, 15 fathoms, mud $(1 / 2)$.

Long. $15-30 \mathrm{~mm}$, alt. $15-33 \mathrm{~mm}$.

Distribution:-- Gulf of Aden. - South Japan, Philippines, Moluccas, Celebes. Pecten velatinus, Sow., in my opinion is identical with the present species.

Pecten fulvicostatus, A. Adams \& Reeve.

Pecten fulvicoslatus, A. Abams \& REEve, Mollusea of the voyage of H. M. S. Samarang, 1848, p. 71, pl. 21, fig. 11.

- - HEFve, Conchol, icon., VIII, Pecten, \$13. 123.

- Maitini u. Chemertz, Conchyl. Cabin., VII, 2 Abth., p, 226, pl. 60. fig. 6

- Dringi, RlEleve, Conchol. icon., VIII, 1853, Pecten, Sp. 152.

- - Marrei u. Chemsitz, Conchyl. Cabin., VII, 2 Abth., p. 207, pl.55, tigs. 7-8.

- Luculenlu, Riervi, Conchol. icon., VIII, 185i, Pecten, Sp. 59."

- laculentus, - Martini u. Chemnitz, Conchyl. Cabin., VII, 2 Abth., p. 170, pl.47, fig.3.

1 Küstek has expressed the same opinion in his Monograph of Pecten in Mantiv \& CunMnitz, loc. eit. p. 9ti.

A. H. Cooke, Anu, and Mag. Nat. Hist., Ser. 5, vol. 17, p. 134. - Bavar, Bull. du Muséum d'Hist. Nat. P'aris, 1901 , p. 366. 
Koh Kram, 20-30 fathoms (4). Between Kolı Mesan and Cape Liant, 9 fathoms (1). South of Koln Chuen, 30 fathoms, shells (1). Between Koh Mesan and Koh Chuen, 25-38 fathoms (1).

Long. 9-19 mm., alt. $10-23 \mathrm{~mm}$.

Distribution:- Gulf of Aden (luculentus, Reeve var.), Red Sea. - Sulu Archip., North Australia, Bathurst Isl. (north-west coast of Australia), Port Molle (Queensland), Cape Capricorn (East Australia), Paumotu IsI.

\section{Pecten (Vola) Sannionis, Chemn.}

l'allium Sannionis, Chemnitz, Conchyl. Cabin., VII, p. 313 (p. p. symonym.), pl. 65, fig. 614.

Pecten spectabilis, REEve, Conchol. icon., VII, 1853, Sp. 128.

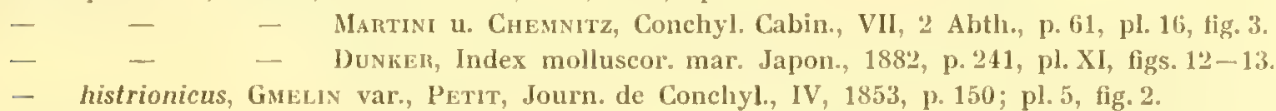

Koh Chuen, 9-38 fathoms, shells $(1+\% / 2)$. Between Koh Kut and Koh Kahdat, 10 fathoms, shells $(1 / 2)$.

Long. 22-30 $\mathrm{mm}$.

Distribution:- Maurilius (Robillaro). - Japan, Nagasaki (Lischke, Dunker).

Chemnrtz's original specimen exists in the Zoological Museum of the University of Copenhagen; on comparing it with the specimens from the Gulf of Siam, ${ }^{1}$ it will be seen that the colouring in the latter is less variegated and conspicuous, but the shape and the characteristic hollow ring-sculpture on the ribs are the same. I have re-introduced Chemnitz's name, hitherto ignored, which has the priority. The species $P$. histrionicus, which was afterwards established by GMELIN, and which is moreover badly characterized (REEvE's figure and description also scarcely represent the species correctly), needs to be more thoroughly investigated on the basis of a greater quantity of material than has hitherto been the case.

Pecten (Chlamys) madreporarum, Pelit (Sow.).

Pecten madreporarmm, PETrT, Sowerix;, Thesaurus Conch., I, p.68, pl. 14, fig. 68.

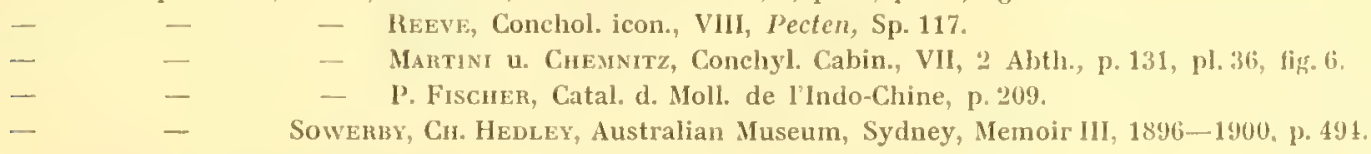

North end of Koh Chang, 1 fathom, old coral blocks $(3 / 2)$.

Long. $20 \mathrm{~mm}$, alt. $24 \mathrm{~mm}$.

Distribution:- Singapore, Poulo Condor, Philippines, Java, New Guinea, Torres Strait, North-east Australia, Fitzroy Ist., New Caledonia, Funaluti (Eillice Isl.).

\section{Amussium paucilirata, Smith.}

Amussium paucilirata, EvG. Sмтт, The Fauna and Geography of the Maldive and Laccadive Archipelagoes II, 1903 , p. 622, No. 301 , pl. 36, figs. $23-24$.

1 These correspond exactly with Dunker's figures in "Index moll. mar. Japon," loc. cit. 
West of Koh Kut, 30 fathoms, sand and mud $(1 / 2)$.

Long. $6 \mathrm{~mm}$., alt. $6 \mathrm{~mm}$.

Distribution:- S. Nilandu Atoll (Maldive Isl.).

In the collections of the Danish Expedition from the Gulf of Siam only one small, transparent, white valve, the left, is found; in this the interior posterior lira is very slightly developed.

\section{Amussium pleuronectes L.}

Ostrea plenronecles, Linné, Systema Nat., ed. X, 1758, p. 696. - ed. XII, p. 1145, No. 190. - Mus. Ludov. Ulr. Reg. 1764, p. 524.

leclen - - Martivi u. Chemisto, Conchyl. Cabin, VII Bd., 2 Abtl.., p. 49, pl. 13, fig. 4.

- $\quad$ - $\quad$ ReEve, Conchol. icon., VIII, Pecten, Sp. 48.

Commonly distributed from Koh Lan to Koh Kut, 8-30 fathoms, mud.

Long. $7-87 \mathrm{~mm}$.

Distribution:- Andamans, Madras, Negapatam, Ceylon. - Poulo Condor, China, Formosa, Japan, Philippines, Moluccas, Java, New Guinea, Torres Strait. Flinders and Clairmont Isls. (North-east Australia).

The number of the internal ribs in the valves varies greatly, therefore Amussium Balloti, Bernardi, ${ }^{1}$ can scarcely be maintained as a distinct species.

\section{Order Eulamellibranchiata.}

\section{Fam. Limidae.}

\section{Lima (Mantellum) fragilis, Chemn.}

Peclen fragilis, (Aneswaz, Conchyl. Cabin., VIl, 1784, p. 349, pl. 68, fig. 650.

Limu - - - Sowenbr, Thesaurus Conchyl., I, 1847, p. 86, No.14, pl.22, tigs. $34-37$.

- ReEve, Conchol. icon., vol. 18, Lima, Sp. 18.

P. Fiscusir, Catalogue d. Mollusques de l'Indo-Chine, p. 210.

Koh Kram, 30 fathoms (1/2). Gulf of Rayong, 7-10 fathoms, sand, mud (2/2). Belween Koh Chuen and Koh Mesan, 15 fathoms, mud (1/2). S. of Koh Kahdal, 8-10 fathoms, mud (1/2). Koh Kahdat (1/2). S. of Koh Mak, 5-6 fathoms (1/2).

Long. 5-15 $\mathrm{mm}$, alt. 8 - $26 \mathrm{~mm}$.

Distribution:- Singapore, Mergui Archip., Nicobars, Persian Gulf, Laccadive and Maldive Archip., Suez, Manitius, Mozambique. - Poulo Condor, Philippines, Amboina, New Guinea, 'Timor, Sorong, Torres Strait, North and East Australia,

Journ. de Concliyl., IX, 1861, p. 46. 
New Caledonia, Sandwich Isls., Fiji Isls., Funafuti (Ellice Isl.), Gilbert Isls., Society Isls.

Several authors (E. V. MARTEns, and others) give L. linguatula, Lam., as a synonym of the present species.

\section{Lima (Mantellum) angulata, Sow.}

Lima angulata, Soweruy, Thesaurus Conchyl., 1, 1843, p. 86, No. 12, pl. 22, figs. $39-40$ (and as $I$. aperta, 6g. 29).

ReEve, Conchol. icon., vol. 18, Linta, Sp. 13.

Radula (Mantellum) angulata, Sow., AxGAs, I'roc. Zool. Soc. London, 1865, p. 656.

Lima angulata, Sow., EDG. Smith, Lamellibranchiata of the Challenger Exped., p. 289.

- orientalis, ADAss and REEve, The Zoology of the voyage of "Samarang." Mollusca, 1848, p. 75, pl. 21, tig. 7 .

Radula (Mantellumi) orientalis, Adams \& ReEve, ANGas, Proc. Zool. Soc. London, 1871, pl. 101.

Lima Basilanica, Abams of ReEve, op. cit., p. 75, pl. 21, tig. 6.

Koh Kram, 30 fathoms (1). Koh Mesan, 15 fathoms, stones (1/2). Between Koh Mesan and Cape Liant, 5-9 fathoms, sand (1/2). S. of Koh Chuen, 30 fathoms, shells (2). North of Koh Chang, 1 fathom, old coral blocks (1). N. of Koh Kahdat, 4-5 fathoms, coarse sand ( ${ }^{2 / 2}$ dead). Koh Kahdat, 1 fathom, sand ( ${ }^{2} / 3$ dead). S. of Koh Mak, 5-6 fathoms $(1 / 2)$.

Long. 5-17 mm., alt. $6^{1 / 2}-26 \mathrm{~mm}$.

Distribution:- Madras, Gulf of Manar. - Philippines, North, East, and South Australia, New Caledonia, New Zealand, Funafuti (Ellice IsI.). Recorded also from Panama and the Bay of Carracas by Cuming and Carpenter.

\section{Lima (Mantellum) dentata, Sow.}

Lima dentata, Sowerny, Thesaurus conchyl., I, 1843, p.87, No. 17, pl. 22, figs. 30 -31.

ReEve, Conchol. icon., vol. 18, Lima, Sp. 14.

HANLEY, Catalogue of rec. biv. shells, p. 268.

North end of Koh Chang, 1 fathom, old coral blocks (8). Koln Kalıdat, 1 - 5 fathoms, sand, and stones (1).

Long. $11 \mathrm{~mm}$., alt. $20 \mathrm{~mm}$. (sp. maj.).

$4 \mathrm{~mm} .,-8 \mathrm{~mm}$. (sp. min.).

Distribution unknown.

Note. Lima squamosa, Lam., was taken by the Danish Expedition at Singapore, on coral reefs, in $2-3$ fathoms (two specimens; long. $12-27 \mathrm{~mm}$. alt. $16-37 \mathrm{~mm}$.). ${ }^{1}$ The "Radula squamosa, Lam., var." interlirala" mentioned by Morcin " is founded on an

1 For further details regarding this species consult:-- Liscuke, Japanische Meeres-Conchylien, I, pp. 162-64; 1I, pp. 155-56. - E. v. Martens, Rumphius Gedenkboek. Mollusken, 1902, p. 18. (Limu Sowerbyi, Dsh.). - Bucouox, Dautzenberg et Dollfus, Les Mollusques marins du Roussillon, II, p. 51. (Radula lina L.) - EDG. SMrti, Lamellibranchiata of the Challenger Expedition, p. 287. -- MELviLt. \& STANDFN, Journ. of the Linn. Soc. Zoology, vol. 27, p. 182. - Tapparone Canerri, Annali d. Mus, Civ. di St. Nat. di Genova, IX, $1876-77$, p. 300 .

Catalogus conchyl. qua reliq. com. de Yoldi, II, 1853, p. 57. The original specimen is in my collection. 
older individual of $L$. squamosa, Itam., in which have developed, between some of the central ribs towards the ventral margin, very slight indications of a rib; the lines of growth also are somewhat prominent; these being individual characters, the form can by no means be maintained as a variety.

\section{Fam. Ostreidae.}

Ostrea cucullata, Born.

Ostrea chcullala, 13ons, Testacea Musei Ccesarei Vindobon., 1780, p. 114, pl. VI, figs. 11-12.

$$
\text { var. Barclayana, Sowerby. }
$$

Reeve, Conchol. icon., XVIII, 1871, Ostroea, Sp. 77.

Koh Chang, on stones at the strand (many specimens). Coast of Lem Ngoli (2). Coast of Koh Kahdat (1).

Long. $35 \mathrm{~mm}$., alt. $42 \mathrm{~mm}$.

$$
\text { var. Forskaili, Chemnitz. }
$$

Conchyl. Cabin., VIII, 1785, p.30, pl. 72, fig.671.

South of Koh Chuen, 30 fathoms, shells (1/2). Coast of Kolı Chang (2).

Long. $37 \mathrm{~mm}$. , alt. $55 \mathrm{~mm}$.

"Bangkok" (Coll. DautzenBerg).

Young individuals of both forms were found in several places in the Gulf of Siam. Ed. v. MARTENS records" that he has taken numerous specimens of 0 . cucullata, Born, at Bangpra in the Gulf of Siam.

D istribution:- Salanga, Mergui Archip., Nicobars, Ceylon, Bombay, Persian Gulf, Gulf of Aden, Red Sea, Suez, Mozambique, Querimba Isls., Mascarenes, coast of Natal, Ascension Isl. - Poulo Condor, Cochin China, China, Formosa, Loo-Choo Isls., Japan, Philippines, Sumatra, Moluccas, Timor, 'Thursday Isl., Mast Head Reef (Queensland), South Australia (? Angas), Viti Isls., New Zealand.

DEshaYes, " characterizes this oyster very correctly when he says that it "aurait mérité le nom de multiformis" because its variability is exceedingly great, and consequently, as may be expected, it has an endless number of synonyms; ${ }^{3}$ to these the following, besides many others, may doubtless be added:- $O$. circumsuta, Gould, ${ }^{+}$O. attenuata, Sow., ${ }^{5}$ and perhaps $O$. vitrefacta, Sow. ${ }^{6}$ Specimens of O.cucul-

1 Zoolog. Ergebnisse ein. Reise in Niederl. Ost-Indien hrsg. v. M. WVEß1, IV, 1897, p. 223.

- Catal. d. Mollusques de l'ile de la liéunion, 1863, p. 36.

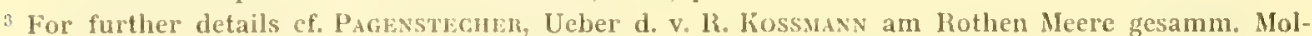
lusken, 1877, pp. 16-24. - Stumany, Lamellibranchiaten d. Rothen Meeres, 1899, p. 37. - L.Ischíw, Japanische Meeres Conchyl., 11, p. 161. - Cookis, Ann, and Magaz. Nat. Hist., Ser. 5, vol. 17, p. 134.

1 Govld, Unit. States Explor. Expedit., pl. 43 , fig. 576. - REve, Conchyl. Cabin., XVIII, Ostrea, Sp. 64. Why REEVE records "Massachusetts?" as its habitat is difficult to understand, as GovLD (Proc. Boston Soc. of Nat. Hist., 1850, p. 346) says that his species was found in the "Fecjee and Samoa Islands." Angas (Proc. Zool. Soc. London, 1867, p. 934) records it from IBotany I3ay.

REEVE, loc. cit. Sp. 49.

"RE:VL, loc, cit. Sp. so 
Lata, Born (and var. Forskali, Chemn.), were taken in Pliocene Deposits in Egypt "in the Lake Deposits of Wadi Natrun at the hill known as Moluk." 1

\section{Ostrea hyotis L.}

Mytilus Il!otis, Lrnwé, Syst. Nat., ed. 10, 1758, p. 704, No. 207. - ed.12, p. 1155, No.244. - Mus. Ludov. Ulr., p. 538, No. 129 .

Ostreca hyotis, - ReEve, Conchol, icon.. XVIII, 1870, Ostrce $\alpha$, Sp. 7.

Var. imbricata, Lamarck.

Ostrea imbricala, Lamanck, Hist. nat. d. anim. s. vert., VI, 1 part. 1819, p. 215, No.46. - éd. 2, VII, 1836 , p. 235 , No. 46.

Ostrea - - Reeve, Conchol, icon., XVIhi, Ostrcea, Sp. 36.

Koh Kram, 30 fathoms $\left({ }^{1} / 2\right)$. S. of Koh Chuen, 30 fathoms, shells $(3 / 2)$. Coast of Lem Ngob (1). S. of Koh Kahdat, 8-10 fathoms, mud (1). E. of Koh Mak, 20) fathoms, mud (1) (Singapore; Sv. GaD. 1/2).

Specimen from Koh Kram: long, $74 \mathrm{~mm}$, alt. $46 \mathrm{~mm}$.

$$
\begin{aligned}
& \text { - } \quad \text { Koh Kahdat: long. } 33 \mathrm{~mm} \text {, alt. } 49 \mathrm{~mm} \text {. } \\
& \text { - } \quad \text { - Koh Chuen: long. } 21 \mathrm{~mm} \text {, alt. } 24 \mathrm{~mm} \text {. } \\
& \text { - } \quad \text { - Koh Mak: long. } 57 \mathrm{~mm} \text {, alt. } 49 \mathrm{~mm} \text {. }
\end{aligned}
$$

Distribution:- O. hyotis has been recorded from: - Ceylon, Gulf of Manaar, Gulf of Aden, Seychelles, Amirantes, Mauritius, Zanzibar. - Poulo Condor, China, Loo Choo Isls., Japan, Philippines, Moluccas, Viti Isls.

O. imbricata has been recorded from:- China, Japan, Java, New Guinea, and by Menvil \& Standen from the Persian Gulf and the Mekran coast.

Since Deshayes (in the second ed. of Lamarck, Anim. s. vert.) wrote regarding O. imbricata that "Cette espèce est inutile, clle a été faite avec une variété jaune de la suivante $($ O. hyotis, Ch.); il faudra donc les réunir sous la dénomination d'Ostrea hyotis," some later authors have upheld the specific distinctness of both the species (Dunker, Reeve, Pilsbriy), some regard them either as varieties or as the same species (Küster, Hanley, Morch).

O. inermis, Sow., is no doubt synonymous with O. imbricata, Lam.

\section{Ostrea rivularis, Gould (Lischke).}

Ostrea rivularis, Gould, Proceed. Boston Soc. Nat. Hist., vol. VIII, 1861, p. 39.

$$
\text { Lischke, Japanische Meeres Conchyl., I, 1869, p. 176. pl. 14, figs. 2-3. }
$$

Gulf of Rayong, 7-10 fathoms, sand and mud ( $1 / 3)$. S. of Koh Samit, 20 fathoms, mud (1/2). Coast of Lem Ngob (1). Sound of Koh Chang, 5 fathoms, soft clay (4). E. of Koh Mak, 20 fathoms, mud (1/2). Between Koh Kut and Koh Kahdat, 10 fathoms, shells (one specimen, and some young odd valves). Strand of Kol Kahdat ( ${ }^{2} / 2$ ) (Singapore, shallow water, one specimen; Sv. GaD).

1 R. Bullen Newton, On some Pliocene and Post-Pliocene Shells from Ëgypt (The Geological Magazine. New Ser., dec. IV, vol. 6, 1899, p. 402, pl. 19, figs. 1-5).

b. K. D. Viciensk. Selsk, Skr., 7. Riekke, naturvidensk, of mathem. Afit. V. 3. 
Long. $74 \mathrm{~mm}$, alt. $54 \mathrm{~mm}$.

- $59 \mathrm{~mm} .,-64 \mathrm{~mm}$.

Distribution:- China Sea, Nagasaki, Yaeyama (?).

A few of the specimens collected were attached to Mangrove-roots. Future comparative investigations will doubtless prove that $O$. rivularis, Gould (Lischke), is only a form of a previously known species, ${ }^{1}$ but I have thought it right to stop my researches at rivularis (with which the specimens from Siam entirely correspond), as a large quantity of material is required to arrive at a reliable conclusion. The whole group (with thin, not folded shell-margin), which includes O. mytiloides, Lam., nigromarginata, Sow., tuberculata, Lam. (= tubercularis, Reeve), Paulucciae, Crosse (= palmipes, Sow.), the collective species arborea, Ch. and parasitica, Gm. (which constantly reappear), and many more, must, on account of their great variability, and the hitherto very uncritical and superficial treatment to which they have been subjected, be carefully investigated and may, no doubt, be considerably reduced.

\section{Ostrea Paulucciae, Crosse.}

Ostrea Pauluccie, Chossw, Journ, de Conchyl., vol. 17, 1869, p. 188; vol. 18, 1870, p. 108, p]. 2 , fig. 5. Ostrea palmipes, Sowerby, ReEve, Conchol. icon., vol. 18, 1871, Ostraca, Sp. 56.

S. of Koh 'Tulu, 10 fathoms, sand mixed with mud (2/2). Sound of Koh Chang, 5 fathoms, soft clay (1). S. of Koln Kahdat, 8--10 fathoms, mud (many young odd valves). Between Koh Krahdat and Koh Kut, 6 fathoms, sand mixed with mud ("3/2). W. of Koh Kut, 15 fathoms, mud $(3 / 2)$.

Long. $28 \mathrm{~mm}$., alt. $20 \mathrm{~mm}$.

D istribution:-- Annam, China, Philipoines.

At Koh Chang (in 5 fathons, on a soft muddy bottom) a smaller specimen was obtained (long. $15 \mathrm{~mm}$., alt. $18 \mathrm{~mm}$.) which seems to me to agree in all points with O. pes-tigris, Hanl.; ${ }^{2}$ it is doubtful whether this form also is entitled to rank as a species.

The specimens from the Gulf of Siam do nol correspond exactly with Crosse's description as regards colour, as in almost all cases they are white with a few lilac rays or shades.

Note. In Morcir's Catalogus conchyl. qua reliq. comes de Yoldi, II, p. 62, No. 783, there is recorded an Ostrea siamensis, Yoldi, from "Singapuhra," as it is, however, not described, either there or anywhere else, I cannot state anything regarding that form.

"Dunker (Index moll. mar. Japon., p. 250) refers it to O. arborea, Ch.

2 Proc. Zool. Soc. London, XII, 1845, p.107. Taken by Cums, at Luzon, Philippines. RExve, Conchol. icon., XVIII, Sp), 78. Sowriby (Append. to marine shells of South Africa, 1897, p. 28) is of opinion that 0 . pes-ligris (REEVE, fig. 78) is synonymous wilh O. Iacerata, Hanl. (= O. lacerans, REEVE). 


\section{Fam. Carditidae.}

\section{Cardita variegata, Brug.}

Gardilu variegatu, Bnugurine, Encyclopedie méthodique. Hist, nat. d. vers, I, 1792, 1).407, No.6, pl. 233, tig. 6 (C. calyculata, Lam.)

\begin{tabular}{|c|c|c|c|}
\hline & & & \\
\hline - & - & - & Reeve, Conchol. icon., I, 1843, Cardila, Sp. 3. \\
\hline - & - & 一 & KKauss, Südafrikan. Mollusken, 1848, p. 13. \\
\hline Iytilicas & rdia - & - & $\begin{array}{l}\text { DE Rochebrune, Faune malacol. de la Cochinchine et du Cambodge } \\
\text { (Bull. Soc. Philomathique de Paris 1881), p. 12, No. 32. }\end{array}$ \\
\hline Cardita & - & - & $\begin{array}{l}\text { Clessin in Mantini u. Cinmeitz, Conchyl. Cabin., X IBd., I Abth., } 1888 \text {, } \\
\text { p. } 23 \text {, No. } 43 \text {, pl. } 3 \text {, figs. } 8-9 \text {, and pl. } 11 \text {, figs. } 5-6 \text {. }\end{array}$ \\
\hline - & - & - & P. Fischer, Catalogue d. Moll. de l'Indo Chine, p. 228. \\
\hline- & & AlRC & (non LiNili), Hist. nat. d. anim. s. vert., 2 éd., VI, 1835, p.431, No. 15. \\
\hline- & - & - & Sowerisy, Genera of rec. and fossil shells. Cardila, figs. $1-2$. \\
\hline - & subaspera, & - & $\begin{array}{l}\text { Hist. nat. d. anim. s. vert, VI, } 1819 \text {, p. } 25 \text {, No. } 16 \text { - éd. } 2, \text { VI, 1. 432, No. } 16 . \\
\text { Déessert, Recueil de coquilles déer. p. Lamarck, } 1841 \text {, pl. 11, fig. 9. }\end{array}$ \\
\hline
\end{tabular}

"Siam" (P. Fischer, loc. cit.).

Distribution: - Singapore, Mergui Isls, Nicobars, Ceylon, Gulf of Manaar, Maldive Isls., Ratnagiri, Persian Gulf, Gulf of Aden, Red Sea, Suez, Seychelles, Amirantes, Zanzibar, Natal, Querimba Isls., Mascarenes. - Poulo Condor, China, Yokohama, Philippines, Sulu Isls., Java, Moluccas, Mast Head Reef (Queensland), Port Essington, Samoa Isls., Viti Isls., Lifu.

The Danish Expedition collected no specimens of this species from the Gulf of Siam, but it has been taken at Singapore in shallow water (by Sv, GaD). A. H. Cooke ${ }^{1}$ writes: "I cannot separate radula, ReEve, from this species."

\section{Fam. Crassatellidae.}

\section{Crassatella radiata, Sow.}

Crassutella radiata, (;. 13. Sow'Enby, Catalogue of the shells in the collect. of the Earl of Taukerville, 1825, Appendix, p. II, pl. 1, fig. 2.

$$
\begin{array}{llll}
- & - & - & \text { Regve, Conchol. icon., I, Crassatella, Sp. } 12 . \\
- & - & - & \text { Martini u. Chemeitz, Conchyl. Cabin., X Bd., } 1 \text { Abth., p. 14, pl. 6, fig. } 2 . \\
- & - & - & \text { Crosse E Fischer, Journ. de Conchyl., vol. 40, 1892, p. } 76 .
\end{array}
$$

Many specimens taken from Koh Lan to Koh Kut, 2-30 fathoms, clay, mud, shells, sand. Very common.

Long. 2-27 mm. (sp. maj. long. $27 \mathrm{~mm}$, alt. $20 \mathrm{~mm}$., crass. $10 \mathrm{~mm}$.).

Gulf of Siam, west coast of Cambodge (PArie).

Distribution: - Singapore (Danish Exp. to Siam, 2-3 fathoms), Mergui Archip., Nicobars, Andamans, Gulf of Manaar, off Mangalore (Malabar-Coast), Gulf of Aden, Red Sea.

\footnotetext{
1 Annals and Magaz. of Nat. Hist., 1886, p. 101.
} 
Several specimens of a shorter, and ventricose form (long. $18 \mathrm{~mm}$, alt. $13 \mathrm{~mm}$, crass. $9 \mathrm{~mm}$.) were taken at Koh Kahdat (in $1-5$ fathoms, on a sandy and stony bottom); a similar form was taken at Koh Mak (in 5-6 fathoms).

\section{Fam. Astartidae.}

\section{Carditella pusilla, n. sp. \\ (PI. III, Figs. 3-5).}

This species is rounded (with the exception of the somewhat prominent beaks), a little inequilateral, dully pellucid, and whitish, (some specimens have brownish-red spots and tints); fairly thick and convex valves, provided with a broad, smooth, heart-shaped Iunule, which is distinctly prominent along the middle. The sculpture consists of 12-13 broad, rounded, radiating ribs, which are at least 3 times as broad as the interstices between them, and are covered with close-set, fine, transverse tubercles. The umbones are acute, median in position, well incurved, and inclined over towards the front. 'There is a single central, strong, acute triangular cardinal tooth in the right valve which fits in between two divergent but smaller teeth in the left. The lateral teeth are distinct on both sides, the anterior in the right valve and the posterior in the left being separated from the outer margin by a deepish groove, the posterior in the former and the front one in the latter being, on the contrary, on the margin. "The hinge-plate between line cardinal and the lateral teeth is seen under magnification to be finely transversely striated. The interstices between the ribs, wherever they appear at the margin, make the latter dentate, and these teeth are each provided on the inner side with a small nodule.

Long $2.5 \mathrm{~mm}$, alt. $2.5 \mathrm{~mm}$, crass. $2 \mathrm{~mm}$.

Between Koh Rin and Clift Rock, 15 fathoms $(3 / 2)$. Koh Kram, 30 fathoms $(2+19 / 2)$. Koh Mesan, 15 fathoms, stones (2). Between Koh Mesan and Cape Liant, 5-9 fathoms, sand $\left({ }^{4} / 2\right)$. Between Koh Mesan and Koh Chuen, 25-38 fathoms, stones $(1+1 / 2)$. Koh Chuen, 10-30 fathoms $(4 / 2)$. South of Koh Chuen, 30 fathoms, shells $(7 / 2)$. Koh Kahdat, $1-5$ fathoms, sand and stones (1/a).

This species is most nearly related to Carditella infans, Edg. Smith, and in my diagnosis I have kept closely to EDG. SMrти's description of that species, so that by comparing the diagnoses it may be easier to form an idea of the diflerences between the two species. In the British Museum there is a Carditella-form labelled "Psephis delecta, A. Ad. (Gouldia delecta)" which is closely related to my species, but diflers from it specifically.

Carditella pulchella, n. sp.

(11. UII, Figs. (6-8).

'I'his liltle species is oval in form, whitish, often ornamented with brownishred spots which appear most distinctly on the interior of the valves; the shell is 
thick and convex. The surface-sculpture consists of $13-14$ strong, distinctly prominent, rounded radiating ribs which bear numerous rather close-set, arched scales, and transverse tubercles. The interstices between the ribs are about as broad as the ribs and have close-set, rough folds and lines of growth. 'The beaks are situated towards the anterior end, they are acute and slope rather suddenly down towards that end, which is rather pointed as compared with the truncated posterior end, towards which the dorsal side descends gradually from the bealis in a straight line. The lunule, which is smooth and oblong, projects a little along the central line. The hinge consists of a single, central, conicai, triangular tooth in the right valve, which fits in between two more slender, divergent leeth in the left; the lateral teeth are well developed and equidistant. The hinge-plate between the cardinal and lateral teeth is seen under magnification to be provided with close-set, fine folds and stria. In the interior the margin is dentate owing to the external ribs projecting there.

Long. $3 \mathrm{~mm}$, alt. $2.5 \mathrm{~mm}$, crass. $2 \mathrm{~mm}$.

Koh Kram, 30 fathoms $(3+4 / 2)$. Between Koh Mesan and Cape Liant, 5-9 fathoms, sand $\left({ }^{2} / 2\right)$. Between Koh Rin and Cliff Rock, 15 fathoms (2/2). E. of Koh Chuen, 9-10 fathoms, shells (1). Koh Chuen, 10-15 fathoms (3/2). Koh Chuen, 30 fathoms $(1+1 / 2)$. S. of Koh Chuen, 30 fathoms, shells $\left(1+{ }^{15} / 2\right)$. Koh Kahdat, 1-5 fathoms, sand $(1+5 / 2)$. N of Koh Kahdat, 4-5 fathoms, coarse sand $\left({ }^{1 / 2}\right)$. Between Koh Kut and Koh Kahdat, 10 fathoms, shells (1). S. of Koh Kut, 17-20 fathoms, mud $(1 / 2)$.

Singapore, shallow water ( $1 / 2)$.

The individuals vary greatly in regard to outline, the position of the umbones, and the sculpture. I am convinced that Card. pulchella does not become much larger than the individuals I have before me, because several of the largest specimens are greatly thickened and solid, $i$. e. increase in size has ceased, and growth is continued only as regards the thickening of the valves. - Card. pulchella is most nearly related to Carditella Torresi, Edg. Smith, which is, however, larger, and differs in several essential points from my species.

\section{Fam. Cyprinidae.}

\section{Trapezium angulatum, Lam.}

Cypricardiu angulala, Iamarck, Hist. nat. d. anim. s. vert., VI, 1819, p. 28, No. 2. - ¿d. 2, VI, 1835, p 438 , No. 2.

Deshayes, Traité élém. de Conchyliologie, 11, 1\%. 18, 1). 24, tigs. 10-11 (C. angulos $\alpha$, Lam.).

- $\quad$ - $\quad$ - Revve, Conchol. icon.. I, 1843, Cypricardia, Sp. 2.

Trapezium angulatum, - H. A. AvAms, Genera of rec. Mollusca, II, 1858, p. 439, pl, 109, fig. 5 a, h. Cypricardia angulata, - Hroalgo, Fauna malacol. de I. isl. Filipinas, II, 1903, p. 365, No. 462.

Chema oblonga, Linvé var., Chemnitz, Conchyl. Cabin., XI, 1795, p. 238, pl. 203, figs. $1993-94$.

Libitina bicarinala, Scmumacher, Essai d'un nouv. systeme d. habitations d. vers testacés, 1817, p. 169. pl. 17, fig. 2 . 
Gypricerdiu rostrala, L.AMasek, Hist. nat. d. anim. s. vert., VI, 1S19, p. 28, No. 3 id. 2, VI, 1835, p. 439 , No. 3. Rrats:, Conchol. icon., I, 1843, Cypricardia, Sp. 3.

Trapezim rostratum, - Dunkek, Index molluscor. mar. Japon., 1882, p. 210.

Koh líahdat, 1 falhom, sand (2). Koh Mak, sandy coast (1/2).

Long. 11-26 $\mathrm{mm}$.

D) istribution:- Andamans, Madagascar, Mauritius, Ile St Mare, Natal, I) - Philippines, Japan, Aru Isl., Torres Str., Port Denison, Kangaroo Isl. (New Holland), New Caledonia, Boston Isl., Viti Isl.

All the specimens from the Gulf of Siam belong to the form rostrata, Lam.

Trapezium vellicatum, Reeve.

Cypricardia vellicala, Riseve, Proc. Zool. Soc. London, 1843, p. 195. Conchol. icon., I, 1813, Cypricurdie, S1. 7.

Trapezium vellicutum, -- Dunker, Index moll. mar. Japon., 1882, p. 210. var., EDg. SMrni in Zoolog. Collect. of H. M. S. "Alert," Lond. 1884, p. 97 No. 21.

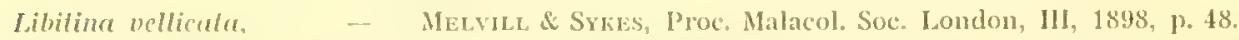
Cypricurdie vellicala, Hmalgo, Fama malacol. de 1. Ist. Filipin., II, 1903, p. 367, No.463. Libilinat Dautzexbere at Fischer, Joum. de Conchyl., vol. 53, 1905. p. 213.

Coast of Lem Ngob), shallow water, stones (29). Gulf of Klong Salakpat (t). Koh Chang, shallow water, stones (5).

Long. $7-30 \mathrm{~mm}$.

Distribution: - Mergui Archip., Andamans, Bombay, Karachi, Persian Gulf. - Philippines, Tonkin, China, Japan, North Australia (Port Darwin), East Australia (Port Curtis).

In all the specimens from the Gulf of Siam the valves, upon their exterior and interior, are quite white without rays or coloration at the posterior end (in some of the specimens the umbones are purplish-brown). Similar forms have been recorded from the Philippines (Cuming), Japan (Dunier), and North Australia (Coppinger).

\section{Coralliophaga coralliophaga, Chemn.}

Chama coralliophaga, Chemsitz, Conchyl. Cabin., X, 1788, p. 355, pl. 172, figs. 1673-74. GMelix, Syst. Nat.. ed. Xill, 1790, p. 3305, Nr. 25.

Cypricardia - GMils, LaMarck, Hist. nat. d. anim. s, vert, VI, I, 1819, p. 28, No. 4. - ed.2, VI, p. 439, No. 4.

Lamangk, REEve, Conchol. icon., I, 1843, Cypricardia, Sp. 12.

Corulliophuga coralliophaya, Guelin, H. \& A. Amsis, Genera of recent Mollusca. pl, 109, tig. 6.

Cypricardia - Chemsitz, Lischis, Japan. Meeres-Conchyl., II, p. 140.

Lilhophagclla, _- _ _ v. Mutrens, Journ. Linn. Soc.; Zool., vol. 21, 1887, p. 214, No. 3723.

Coralliophagu Gmein, Venpule and Bush, Trans. Connecticut Acad., X, 1900, p. 520, pl.63, ligs. 9-10.

Chimettz, Hidargo, Fanna malacol. d. las isl. Filipinas, 1I, 1903, p. 369, No. 4137.

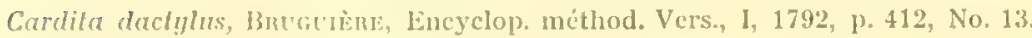

Coralliophaga dactylus, Bnugutèn, Monch, Catal. conchyl. qua reliq. Foldi, II, p. 19, No. 199. 
Trupezium dactylus, Bnuguièn, H. Kners, West-Indian ma1, shells, 1864, p. 123.

Coralliophaga daclylus, Bhuguine, P. Fischer, Moli, de I'Indo-Chine, p. 230.

carditoidea, Blaisville, Manuel de Malacol. et de Conchyl., 1825, p. 560, pl. 76, fig. 3.

Cypricardia Hornbeckiana, D'Onugxy, Moll. de l'ile de Cuba, II, 1853, pl. 266, No. 464, pl. 26, figs. $33-34$.

- gracilis, Shuttenworth.

Trapezium - _ - H. KneBS, West-Indian mar. sliells, 1864, p. 123.

Coralliophaga siriolala, H. Avans, Proc. Zool. Soc. London, 1870, p. 791, pl. 48, fig. 12.

lithophagella, DUnker (non LAMA Cr), Index moll. mar. Japon., 1882, p. 209).

Koh si Chang (2/2). Klong Salakpat (1). Koh Chang, 1 fathom, old coral blocks (taken in great numbers). North end of Koh Chang, 1 fathom, old coral blocks (अ/2). Koh Kahdat, 1 fathom, sand (1).

Long. 2-32 $\mathrm{mm}$.

Distribution:- Mergui Isl., Aden, Red Sea, Mauritius. - Poulo Condor, Philippines, Japan, Yap Isl., Uvea (Wallis Isl.), Lord Howe's Isl. - East coast of America: Florida (Cedar Kieys), Greater and Lesser Antilles.

A. H. Coore is of opinion that ReEve's C. laminata is probably synonymous with C. coralliophaga, Chemn. - Several of the specimens from the Gulf of Siam (at any rate the individual which was taken alive at Koh Kahdat, on a sandy bottom) convey the impression of not always boring in corals. It is a characteristic mark of distinction in this species that it has, on both apices, a small, dark stripe, which occurs in the specimens from both. American and Asiatic waters.

\section{Fam. Lucinidae.}

\section{Lucina (Thyasira) edentula L.}

Tenus edentula, Linne, Syst. Nat., ed. X, 1758, p. 689, No. 122. - ed. XII, p. 1135, No. 146. . Mus. Ludov. Ulr., 1764, p.508, No. 74 (non L. edentula, LAMaвck)

Lucina - - PHuLp', Zeitschr. f. Malakozool., 1845, p. 179.

$-\quad-\quad$ Abbild. u. Beschreib. neuer od. wen. gek. Conchyl., 11. 1847, 1.. 205, 11. 1,
fig. 1.

- - - Dunker, Index molluscor. mar, Japon., 1882, p. 216, pl. 8, figs, 7-8.

- (Anodontia) edentula L., v. MAntexs, Journ. Linn. Soc., Zoology, vol. 21, 1887, p. 173, No.65.

- edentulu, Linvé, v. MAntens, Süss- u. Brackwasser-Mollusk. d. Ind. Archip., p. 229, pl. XI, figs. 1-2.

- Philippiana, Reeve, Conchol. icon., VI, 1850, Lucina, Sp. 23, and pl. V, fig. 25.

S. of Koh Chuen, 30 fathoms (9/3).

Long. 32-60 $\mathrm{mm}$.

Distribution:- Singapore, Mergui Archip., Nancowry Isl. (Nicobars, "Galathea" Exp.), Gulf of Manar, Suez, Red Sea (Forskíl, according to specimens from him, in the Zool. Mus., Copenhagen ${ }^{1}$ ). - Japan, Liukiu Isl., Philippines, Moluccas, Lifu, Sulu Isl., Upolu, Tongatabu.

In the Zoological Museum of the University of Copenlagen there are preserved under the name of L. fragilis, Phil. (Krauss), 3/2 specimens (which undoubledly were contributed by Krauss himself) of L.edentula L. from Port Elizabeth (Cape), size as follows: - long. $49 \mathrm{~mm}$., alt. $45 \mathrm{~mm}$., crass. $37 \mathrm{~mm}$., a size never altained by

1 The specimens were determined as $L$. globosu, Forsk. 
L. fragilis, Phil. (or L. lacteus L.). ${ }^{1}$ Sowerny (Marine shells of South Africa, 1892, p.61) also states Port Elizabeth as the locality for L.fragilis, Phil.; this is, however, due to erroneous determination, as the most southerly limit of distribution for these forms is the Cape Verd Islands and Loanda Island. In the supplement to "Marine Shells of South Africa" Sowerey also says, regarding Loripes clausus, Phil., from Natal: "This is the shell quoted by me, pl.61, as Loripes laclens" (according to SowErBY L. lactens L. is identical with L. fragilis, Phil.). In the specimens in the Museum in Copenhagen the cardinal and lateral teeth are entirely wanting; moreover, they do not at all resemble Luc. clausa, Phil. ( = L. barbala, Reeve). Krauss's descrip)lion of his specimens, which are also from Port Elizabeth, ("auf dem linken Ufer des Zwartkopflusses") 2 corresponds exactly with L.edentula L., therefore I do not lnesitate to put L. fragilis, Krauss $=I$. edentula L. DuxkEn's figure (Index noll. mar. Japon., PI. VIII, Figs. 7-8) of L. edentula L. Lesta junior, looks very remarkible and conveys the impression that the specimen figured must be abnormal.

\section{Lucina (Thyasira) ovum, Reeve.}

Lncina onnm, Rerve, Conchol. icon., VI, 1850, Lucina, Sp. 21.

Loripes - - Avgas, P'roc. Zool. Soc. London, 1867, p. 926, No. 89.

lioh Mak, sandy coast $\left({ }^{1 / 2}\right)$.

Long. $15 \mathrm{~mm}$.

Distribution:- Andamans (Zool. Mus., Copenhagen). - Philippines, Botany Bay.

As mentioned under $L$. vesicula, $L$. ovum is not easy to unravel. It is not so tumid as L. tumida, neilher does the rather straight dorsal side pass so roundly into the posterior end, the transition being more sudden. A great many authors have looked upon Diplodonta globosa, Forsk, quite erroneously and have considered it to be identical with Luc, ovum, Reeve (for further details compare Diplodonta globosa, Fiorsk.).

\section{Lucina (Thyasira) bullula, Reeve.}

Incina bullula, REEvE, Conchol, icon., VI, 1850, Lucina, Sp. 35.

Cryplodon bullulus, Revve, EDG. SMrth, Rep. on the Lamellibranchiata of the Challenger Exped., p. 189.

Between Koh Mesan and Cape Liant, 5-9 fathoms ( $\% / 2)$. West coast of Koh Chang, 10 fathoms, mud (1/2). N. of Koh Kahdat, 4-5 fathoms, coarse sand (1/2). W. of Koh Kut, 15 fallioms, nud $(1 / 2)$.

Long. 5- $10 \mathrm{~mm}$.

Distribution:- Amboina ("Challenger"), Adelaide, Port Essington (Brit. Mus.).

1 Buconoy, Dautzenberg et Dollfus, Moll. mar. de Roussillon, II, p. 627, give the following measurements for I. lacteus: - long. $23 \mathrm{~mm}$; alt. $22 \mathrm{~mm}$, crass. $13 \mathrm{~mm}$. Kionelt, Prodromus faunae moll. test. mar. curop. inhab., p. 370, gives the following measurements for L. fragilis, Phil.: - long. 9 mur, alt. $10 \mathrm{~mm}$.

"Die südafrikanischen Mollusken, 1818 , p. 5 , No. 3. 


\section{Lucina (Thyasira) vesicula, Gould.}

Lncina vesicula, Gout1, P'roc. Boston Soc. Nat. Hist., III, 1850, p. 256. - Expedition Shells, p. 82. Unit. States Expl. Exped., 1838-42, Mollusca \& Shells, 1852, p. 414, pl. 36, fig. 525. Cryptodon - _ - Thurston, Rámésvaram Isl. and Fauna of the Gulf of Manaar, 2 ed., 1895, p. 129.

Strand of Koh Mak and Koh Kahdat ( $/ 2)$.

Long. 20-28 $\mathrm{mm}$.

Distribution:- Gulf of Manaar. - Tonga Isl.

From the descriptions and figures of REEvE's species ovum, tumida, and pila, it is not possible for me to form an opinion of their reciprocal relation and position to vesicula, Gould, and so I have adopted the name of Govln's form vesicula, which entirely agrees with the specimens from the Gulf of Siam.

\section{Lucina (Codakia) punctata L.}

Venuts punctata, I.rnve, Syst. Nat., ed. X, 1758, p. 688, No. 116. - ed.XII, p. 1134, No. 140. - Mus. Ludov. Ulricze, p. 505 , No. 69.

Chemnitz, Conchyl. Cabin., VII, p. 15, pl. 37, figs. 397-98.

Lenlillaria punclata, Linné, Schumacher, Essai d'un nouv, syst. d. habit. d. vers. testacés, 1817, p. 148, pl. 15, fig. 4 .

Cytherea - - Lasarck, Hist. nat. d. anim. s. vert., V, 1818, p. 574, No. 54. - éd. 2, VI, p. 319 , No. 54.

Lucina - - Deshayes, Dictionn. class. d'hist. nat., IX, 1826, p. 531.

Codakia - - GraY, Proc. Zool. Soc. London, XV, 1847, p. 196, No. 684.

Litcina - - REEvE, Conchol. icon., VI, 1850, Lucina, Sp. 2.

- - Pfeiffer, in Martini u. Chemeitz, Conchyl. Cabin., XI, 1 Abtl., 1869, p. 262, No. 4, pl. 19 , figs. 8-9.

(Lentillaria) punctata L., v. Mantens, Moll. d. Maskarenen u. Seychellen, 1880, p. 145.

punctata L., MorLet, Journ. de Conchyl., vol. 37, 1889, p. 173, No. 94.

"Iles du golfe de Siam" (MORLET).

The Danish Expedition to Siam collected no specimens of this species.

Distribution:- Maldive Archip., Seychelles, Amirantes, Iles Glorieuses, Masearenes, Querimba Isls. - Ihilippines, Ceram, Timor, Mariamne Isls, New Caledonia, Lifu, Funafuti Atoll, Viti Isls., Samoa Isls., Rarotonga.

\section{Lucina (Codakia) venusta, Phil.}

Lucina venusta, Pmuppi, Abbild. u. Beschreib. nener od. wen. gek. Conchyl., II, 1817, p. 206, No. 3, pl. I, fig. 2.

ReEve, Conchol. icon., VI, 1850, Lucina, Sp. 15.

(Myrtea) venusta, Phirppr, Tryon, Proc. Acad. Nat. Sc. Philadelphia, 1872, p. 89, No. 16.

venusta, Philipi, Morlet, Journ. de Conchyl., vol. 37, 1889, p. 173, No. 95.

"Iles du golfe de Siam" (L. Morret).

The Danish Expedition to Siam collected no specimens of this species.

Distribution:- Philippines. 
Lucina (Codakia) divergens, Phil.

Lncina divergens, PHilippr, Abbild. u. Beschreib. neuer od. wenig gek. Conchyl., III, 1850, p. 103, pl. 2, tig. 4.

- E. v. Martens u. Langkatri, Donum Bismarckianum, 1871, p.63

- Lischí, Japanische Meeres-Conchyl., II, 1871, 13. 132.

- (Lentillaria) divergens, E. v. Mantroxs, Moll. d. Maskarenen u. Seychellen, 1880, p. 145.

- fibula, Rlsive, Conchol. icon., VI, 1850, Lucina, Sp. 33, pl. 7, figs. 33, 37, 38.

- _ - ADsiss \& ReEve, Zoology of "Samarang" Mollusca, p. 80. pl. 24, fig. 5.

- ramulosa, Goubs, Unit. States Explor. Exped. 1838-42, XII, Moll. \& Shells, 1852, p. 415, pl, 36, fig. 523. - I'roceed. Boston Soc. Nat. Hist., JII, 1850, p. 255, - Expedition Shells, p. 82.

- (Codakia) munda, A. Adass, Proc. Zool. Soc. London, 185., p. 225, No. 18.

Codakia bella delicatula, PILSBry, Proc. Acad. Nat. Sc. Philadelphia, vol. 56, 1904, p. 555, pl. 41, figs $15-16$.

North end of Kolı Chang, old coral blocks, 1 fathom (1/2). Kolı Lom, west of Koh Chang (1). Between Koh Kahdat and Koh Kut, 6 fathoms, clay mixed with sand $(1 / 2)$. Koh Kahdat $(1 / 2)$. Koh Mak, sandy coast $(1 / 2)$.

Long. 5- $13.5 \mathrm{~mm}$.

Distribution:- Mergui Archip., Gulf of Manaar, Maldive Isls., Bombay, Persian Gulf, Red Sea, Mascarenes, Isl. of Rodriguez. - Philippines, China Seas, Japan, Torres Strait, Port Essington, east coast of Australia as far as Sydney (New South Wales), King Isl. (Tasmania), Mariannes, Ladrones, New Caledonia, Lifu, New Hebrides, Viti, Funafuti Atoll, Samoa, Hervey Isls., Rarotonga, Tahiti, Paumotu Isl.

The specimens from the Gulf of Siam come nearest to the variety delicatula, from Riukiu Island, described by Prssny (loc. cit.). - The boundary line of this species is not quite settled and requires to be investigated more closely; REEvE's "fibula" is no doubt also a collective species. DAL. (Synopsis of the Lucinacea, 1901, p. 798) is of opinion that PHilpri's name divergens must yield place to Conrad's L. bella, which has the priority; it is, however, doubtful if these two species are synonymous. In 1834 Conrad (Journal of the Acad. of Natur. Sciences of Philadelphia, VII, p. 254) described Lucina bella from specimens collected by. Mr. "T'H. Nuttall "in muddy marshes near Sta. Diego" (Upper California); ' but Dalc thinks that there must have been a mistake, and that the specimens were "probably" collected at the Sandwich Islands. Before rejecting PmLrpr's "divergens," all the forms in question should be thoroughly investigated.

\section{Lucina (Codakia) fijiensis, Sm.}

Lucina (Codakia) fijiensis, Eng. Smith, Rep. On the Lamellibranchiata of the Challenger Lxpedition, 1885 p. 181, pl. 13, tig. 9.

Between Koh Mesan and Cape Liant, 5-9 fathoms (1/3). Strand of Koh Kahdal (A single worn valve).

Long. $9.5 \mathrm{~mm}$, alt. $9 \mathrm{~mm}$, crass. $8 \mathrm{~mm}$.

i See also P’. P. Cahmentar, Monogr. of the Shells collected by T. Nuttall on the Californian Coast (1'roc. Zool. Soc. London 185t;, p. 218, No. 47). 
Distribution:- Oll Levuka, Fiji Isls. (EDg. Smiti).

The fresh, left valve oblained from the Gulf of Siam is about double the size of the right valve from the Fiji Islands on which EDG. Smitn lounded the species, but it exactly agrees with his description. 'To EDG. SMru's diagnosis, which is otherwise very good, may be added: It is not only on the hinder side that the fine transverse strix are a little lamelliform, but also on the anterior side; in the left valve are two cardinal teeth, separated by a deepish pit, the anterior is the larger; there is, moreover, a corresponding lateral tooth, exactly like the one described by SuTn, in the right valve. The interior of the valves have fine, white radiating rays, which stop at the pallial line. Luc. pisidium, Dkr., is very closely allied to the present species.

\section{Lucina (Codakia) minima, Ten. Woods.}

Lucina minima, Trevisos IVoons, Descript. of New Tasmanian Shells, 1875, p. 30 (Proc. R. Soc. Tasmania, 1876, p. 162).

TAte and MAY, Proc. Linn. Soc. New South Wales, 1901, p. 431 Prithalid and GathifF, Proc. H. Suc. Victoria, 1903, XVI, p. 138,

- (Codakia) Talei, Avgas, Proc. Zool. Soc. London, 1878, p. \$63, pl. 5t, tig. 15.

Between Koh Mesan and Cape Liant, 5-9 fathoms (2/3). Between Koh Kahdat and Koh Kut, 6 fathoms, clay mixed with sand $(1 / 2)$. Sound of Koh Chang, 3-5 fathoms, soft clay (2).

Long. $1-3 \mathrm{~mm}$.

Distribution:- Singapore, shallow water (Sv. GaD). - Victoria ("coast generally"), Cape Northumberland, Tasmania, St. Vincent's Gull.

\section{Lucina (Loripes) desiderata, Sm.}

Incina (Loripes) desilerala, EDG. Sмmт, Report on the Lamellibranchiata of the voyage of H. M. S. "Cliallenger," 1885, p. 185, pl. 13, fig. 10.

Koh Chuen, 10-15 fathoms ( $1 / 2)$. W. of Koh Chuen, soft clay and mud $(9 / 2)$. W. of Koh Kut, 15 fathoms $(1 / 2)$. S. of Koh Kut, 17-20 fathoms, mud $(1 / 2)$.

Long. 3-7 mm., (long. $7 \mathrm{~mm}$, alt. $7 \mathrm{~mm}$, crass. $4.5 \mathrm{~mm}$.).

Distribution: - South of New Guinea.

"The individuals collected by the "Challenger" Expedition reached a size of only $3^{1 / 3} \mathrm{~mm}$. in length; the largest specimens from the Gulf of Siam measure $7 \mathrm{~mm}$., and are in addition very thin-valved and fragile. The individuals measuring $3 \mathrm{~mm}$. in length agree exactly with Edg. Smith's figures; in the larger specimens (dead ones) the dentiform projections at the lunule and on the hinder dorsal side are not so prominent, but this is perhaps due to a bad state of preservation.

\section{Lucina (Phacoides), Dalli n. sp.}

(Pl. III, Figs. 9-12).

This species is a litte higher than long, somewhat inequilateral, moderately convex and thick, white, and marked with two (often more) radiating depressions 
down the anterior side and one broader radiating depression down the posterior side. It is almost circular in outline, but the posterior end is rather straightly truncated. The surface is covered with numerous close-set, regularly-arranged, fine, slender lira, which towards the lunule and hinder dorsal slope are more elevated. The lunule is rather deep and large, cordiform, smooth. The area is long and narrow. The beaks are small, sharp, well-curved over the lunule. The valves are covered (in quite fresh individuals) with an extremely thin epidermis, which under the lens exhibits a few fine radiating lines. In both valves the lateral teeth are well-developed, the posterior being the smaller, and the cardinal teeth are obsolete; the internal ligament is in a groove just within the dorsal margin. The interior of the valves is of a dull white colour and under the lens is seen to have fine, faint, radiating lines.

Long. $7.5 \mathrm{~mm}$, alt. $8 \mathrm{~mm}$, crass. $5 \mathrm{~mm}$.

The strand off the mangrove at the station on Koh Chang (54).

The peculiar depressions down the anterior side are characteristic of this species. The shell varies rather considerably in form; especially in older specinens it has a tendency to be drawn obliquely towards the anterior end, so that the umbones may even be situated far back in the hinder half of the shell, while in other individuals they are situated in the middle of the length of the shell. I have named this new species after Mr. W. H. DiLL of Washington to whom malacological science owes so many valuable papers, and who has also revised the genus Lucinx.

Lucina (Phacoides) pisum, Reeve.

Lacina pisum, KIEve, Conchol, icon., VI, 1850, Lucina, Sp. 66 (non Lucina pisum, Philippi ${ }^{1}=$ Divaricella perparvula, Dall²).

- (Codakia) pisum, Rizve, Evg. SmTi, Lamellibranchiata of the Challenger Exped., p. 181.

Parvilucina cucosmia, DALL, Synopsis of the Lucinacea, 1901, p. 806.

Between Koh Mesan and Cape Liant, 5-9 fathoms, sand (1/2). Between Koh Riot and Koh Mesan, 3-5 fathoms, sand (2/2). S. of Koh Chuen, soft clay and mud (15/2). Gulf of Rayong, 7-10 fathoms, sand, mud, and shells (1/2). S. of Koh Samit, 14-20 falloms, mud $(1+2 / 2)$. Off Tung Kaben, 6 fathoms, mud mixed with sand $\left({ }^{1} / 4\right)$. Koh Chang, between stones, very low tide (1). West coast of Koh Chang, 10 fathoms, mud (1/2). N. of Koh Kahdat, 4-5 fathoms, coarse sand $(1 / 2)$. Koh Kahdal, on the strand (ahout $200 / 2$ specimens). S. of Koh Kahdat, 8-10 fathoms, mud ( $(/ 2)$. Between Koh Kut and Koh Kahdat, 10 fathoms, shells (36/2). W. of Koh Kut, 18 fathoms, mud (9).

Long. 2-6 mm.

Distribution: - Singapore (Cumng; Sv. Gad, 2-3 fathoms). Mergui Isls. (E. v. Martens), Madras (Melvild e Standen), Gulf of Manaar (Thunston). - S. of New Guinea ("Chaldenger"), Port Essinglon (Brit. Mus.).

1 Abbild. u. Beschr. neuer od. wen. gek. Conchyl., 111, 1850, p. 105.

"Synopsis of the Lucinacen. Wash. 1901, p. 815. 
EDg. SMrtu" says regarding this species that "The radiating costa in this species are only about eleven in number, very strong, and crossed by about sixteen stout concentric ridges, which are somewhat nodose upon the costre, and gradually attenuated at both ends, which are devoid of longitudinal ribs." This does not exactly correspond with the rather large quantity of material which I lave at my disposal from the Gulf of Siam. From this it appears that the radiating ribs are not so prominent at the anterior end ${ }^{2}$ as at the middle, where there are about 15-20 radiating ribs and (in a specimen measuring $6 \mathrm{~mm}$. in height) about 23 concentric folds; ${ }^{3}$ the latter are, at the posterior end, almost smooth and without radiating striae.

\section{Lucina (Phacoides) pulchella, n. sp.}

(Pl. III, Figs. 13-15).

This little species is irregularly rounded, rather thin, white, convex, inequilateral. The sculpture consists of about 11 stout, strong, radiating costa, of which several divide, so that in larger specimens there are about 20 ribs at the ventral side. The ribs, which are broader than the interstices between them, are crossed by close-set, fine, raised concentric lira. The radiating ribs are considerably predominant over the concentric lines. At the anterior and posterior ends of the valves the radiating ribs are absent, but the thread-like concentric lira are present. The lunule, which is smooth and oblong-cordate, is deeply excavated beneath the overcurving umbones, each of which is smooth at the bluntish tip. The area is oblong, rather narrow, and smooth. In the left valve are two cardinal teeth, and in the right valve there is one. The lateral teeth are small in both the valves. The somewhat thickened inner margin is dentate, most decidedly towards the ventral and front sides; at the upper part of the anterior end these marginal teeth are very fine and small, and they disappear at the upper part of the posterior end.

Long. $4 \mathrm{~mm}$, alt. $4 \mathrm{~mm}$., crass. $3 \mathrm{~mm}$.

Koh Lan, 30 fathoms, mud $(3 / 2)$. Koh Kram, 30 fathoms $\left({ }^{1} / 2\right)$. Koh Chuen $(3 / 2)$. E. of Cape Liant, 9 fathoms, shells $(1 / 2)$. Koh Mesan, 15 fathoms, slones ( $3 / 2)$. Between Koh Mesan and Cape Liant, 9 fathoms, sand (6). S. of Koh Samit, 20 falloms, mud $(1 / 2)$. S. of Koh Chuen, soft clay and mud (3/9). Between Koh Chuen and Koh Chang, 15 fathoms, mud (1/2). Koh Kahdat, 1-5 fathoms, sand and stones (3). Between Koh Kahdat and Koh Kut, 6 fathoms, clay mixed with sand $\left({ }^{6} / 2\right)$. W. of Koh Kut, 15 fathoms (2). W. of Koh Kut, 30 fathoms, sand and mud ( $1 / 3$ ).

This little species is most nearly related to the small group of species: seminula, Gould, pisum, Reeve, and Semperiana, Issel, from which it differs, however,

1 Report on the Lamellibranchiata of the Challenger Expedition, p. 181.

See REEVE's figure, pl. $\mathrm{XI}$, tig. $66 \mathrm{~b}$.

3 This causes the folds to become strongly erenulated, which results in the lower margin of the valves becoming strongly dentate within; the lower inner posterior side, owing to the very feeble radial striation, is only (as EDG. SMrTH states) "very minutely crenulated," 
by the absence of the strong depression down the hinder side of the valves and the feebler one in front, and by some of its radiating ribs - which are considerably stronger than the concentric ribs - dividing in the middle of the valves.

\section{Lucina (Phacoides) seminula, Gould.}

Lucina Mfyrtea semimula, Gourv, Proc. Boston Soc. Nat. Hist., VIII, 1861, p. 36.

(Codakia) - Eng. SmTh, Rep. Lamellibranchiata of the Challenger Exped., p. 180, pl. 13, fig. 5.

S. of Koln Samit, 20 fathoms, mud $(1 / 3)$.

Long. 1.5 mm.

Distribution:- Hong Kong Harbour; south of New Guinea.

DALL refers this and allied forms (L. pisum, Reeve, and others) to the subgenus Parvilucina, section Bellncina.

\section{Diplodonta amboinensis, Sm.}

Diplodonta amboinensis, Evg. Ssitu, Report on the Lamellibranchiata of the Challenger Exp., 1885, p. 199, pl. 14, fig. 12.

Gulf of Rayong, 7-10 fathoms, sand and mud (1/2). Between Koh Chuen and Koh Chang, 15 fathoms, mud ( $(2 / 2)$. Koh Mak, sandy coast (2/2). N. of Koh Kahdat, $1-5$ fathoms, coarse sand (2/3). Koh Kahdat, 1 fathom, sand (3/2). Between Koh Kut and Koh Kahdat $(2 / 2)$.

Long. 5-19 $\mathrm{mm}$.

Distribution:- Amboina ("Challenger").

This species is very closely related to Dipl. rolundata, Mont.

\section{Diplodonta ethima, Melv. \& Stand.}

Diplodonta elhimu, Melulu and Standen, Joum. Linn. Soc. Zoology, vol. 27, 1899, p. 197, pl.11, fig. 17.

Koh Kram, 30 fathoms (2). Gulf of Rayoug, 7--10 fathoms, sand and mud $(1 / 2)$. Between Koh Mesan and Koh Chuen, 25-30 fathoms, stones and shells (1/2). S. of Koh Chuen, 30 fathoms, shells (3/2). Between Koh Chuen and Koh Chang, 15 fathoms, mud (1/2). Off Tung Kaben, 6 fathoms, mud mixed with sand (1). Coast of Lem Ngob, low tide (1/2). Between Koh Kut and Koh Kahdat, 10 fathoms; shells (13/2). Koh Kahdat, 1-5 fathoms, sand and stones (2/3). S. of Koh Kahdat, 8-10 fathoms, mud (5/2). W. of Koh Kut, 30 fathoms, sand and mud (1/2).

Long. 4-10 $\mathrm{mm}$. (long. $10 \mathrm{~mm}$, alt. $9.5 \mathrm{~mm}$., crass. $6.5 \mathrm{~mm}$.).

Distribution: - Singapore, low water (Sv. Gad), Torres Strait (Melvild \& STANIEN).

The specimens from the Gulf of Siam vary rather considerably in form, and it will doubtless, at some time, be proved, when the Diplodonta-group has been critically investigated - which it greatly needs - that D. ethima has a wider distribution; it hides itself perhaps under other names. 


\section{Diplodonta conspicua, Smith.}

Diplodonta conspicua, EvG. Surm, Report on the Lamellibranchiata of the Challenger Exped., 1885, p. 198 , pl. 14, fig. 11.

Sound of Koh Chang, 5 fathoms, soft clay ( $1 / 2)$. Koln Kahdat, 1 fathom, sand $(61 / 2)$. S. of Kolı Kahdat, 8-10 fathoms, mud (5/2). Between Koh Kut and Koh Kahdat, 6-10 fathoms, clay mixed with sand, and shells $(3 / 2)$. N. of Koh Kut, 10 fathoms, mud $(3 / 2)$. W. of Koh Kut, 15 fathoms, mud $(2 / 2)$. W. of Koll Kut, 30 lathoms, sand and mud $(1 / 2)$.

Long. 2-11 mm. (long. $11 \mathrm{~mm}$, alt. $10.5 \mathrm{~mm}$., crass. $7 \mathrm{~mm}$. .).

Distribution: - Flinders Passage, Torres Strait.

Surti's specimens from the Challenger Expedition have a length of only $4 \mathrm{~mm}$., while the specimens from the Gulf of Siam may measure as much as $11 \mathrm{~mm}$. in length. Edg. Sмiти has overlooked (or perhaps they were but indistinctly visible in his small individuals) that besides the characteristic denticulalions on the inner front margin there also occur $3--5$ corresponding denticles on the inner hinder margin, at the same level as those on the front side. SMrti mentions the presence of 5 to 6 distinct denticles on the inner front margin, this is certainly often the case, but most frequently $7-9$ denticles occur both on larger and smaller specimens.

Note. It is strange how Diplodonta globosa, Forskål, has been misapprehended, and confusion thereby brought into the literature, although both Forskí and Chemnitz have given good diagnoses and figures of it. Forskil's original specimens, contained in Spengler's collection, on the basis of which Chemnitz wrote his description, are now preserved in the Zoological Museum of the University of Copenhagen. In the following I shall give a summary of the views, partly erroneous, of the different authors, concerning this species and its synonymy:-

Tenus globosa, Forskil, Descript. animal. qua in itin. orient. observ., 1775, p. 122, No.53.

Chemitz, Conchyl., Cabin., VII, 1784 , p. 36 , pl. 40 , figs, $430-31$.

I.ncina sp., SAvıgny, Iconographie d. Moll. de l'Égypte, pl.8, fig. $7=$ Dipl.globosa, Forsk. In the explanation of the figures Audouin erroneously names this species Lucina edentula. Varliant Journ. de Conchyl., XIII, 1865, pp. 124-125) and, on his authority, Issel (Malacologia d. Mar Hosso, 1860 , p. 358) refer SAvigny's figure to Diplodonta Savignyi, Vaill. E. v. Marrens (Vorderasiat. Conchylien, p. 103) says in regard to this point: "Fischer und ISSEL haben übrigens Unrecht, die Abbildung in der Description de l'Égypte Pl. S, Fig. 7 hierher zu citiren, da diese nach der Zeichnung der Muskeleindrücke eine richtige Lucina darstellt, olnne Zweifel $L$. globosa, Forsk." Valllant's Diplodonta Savignyi, according to my opinion, is identical with Diplodonta globosa; on the other hand Vaillant's Lucina globosa can scarcely be Chemsitz's (Forskål's species of this name.

- globosa, Chemnitz, Gray, The Annals of Philosophy, New Ser. IX, 1825, p. 136.

- Globosa, - HaNLer, IHl. Catal. rec. biv. slells, p. 78.

Diplodonta bullata, Dunker, Novitates Conchologicae, II, Meeres Conchyl., p. 76, No. 83, pl. 26, figs. 1-3 = Dipl. globosa, Forsk.

Lizcina globosa, Forkil, Pfeiffer in Martini u. Chemnitz, Conchyl. Cabin., XI, 1 Abth., 1869, 1. 267, pl. 20 , tigs. $11-12$.

- (Loripes) globosa, Ciesnitz, Issish, Malacol. del Mar Rosso, 1869, p. 85, No. 107.

- Anodontia) globosa, Fonskil v. Martexs, Mollusken d. Maskarenen u. Seychellen, 1880, p. 146. (v. Mantens regards here erroneously, L. pila, Reeve (Conchol. icon., Sp. 24), as a synonym of the present species. REEvE (Conchol. icon.) says expressly regarding the species figured on Pl. V, iSp. 21-24), that they have "the hinge toothless," which is not at all the case in L. globosa, Forsk. The fact that v. MARTENs refers this species to the subgenus Anodontia (as also the observations he makes elsewhere regarding this species, proves that his view of it is wrong, and that he has overlooked what is expressly stated in CHEMnTz's diagnosis: "Im Sclilosse stehen in jeder Schale nur zween Zähne."). 
Lncina globosa, Fonskà, A. H. Cooke, Rep. on the Testac. Moll. obt. in the Gulf of Suez (Ann. and Mag. Nat. Hist., 1886). V., p. 99 (Cookr, like v. MarTeNs, is wrong with regard to L. globosa, as he gives REEve's species L. pila, tumida and ovum as its synonyms, and adds: "In the Brit. Mus. pila, Reeve, is given as = chrysostoma Mensch. (o: Meusch.). The same authority unites vesicula, (iould, with globosa, Forsk., but this appears to me most unlikely." On the same page lie writes: "Diplodonta Savignyi, Vaill, figured in Savigny, pl. VIlI, fig. 7." This misapprehended figure is a very good illustration of the real Diplodonla globosa, Forskal).

Loripes globosus, Chemnitz, Jousseanme, Deser. d. Moll. rec. par Faurot dans la Mer Rouge et le Golfe d'Aden, 1888. (Mém. Soc. Zool. France, I, pl. 2, p. 210, No. 164).

- Forskíl, Sowerib, Marine Shells of South Africa, 1892, p.61, pl, 4, fig. 91 (is scarcely Diplodonta globosa, Forsk.).

Lucina (Cyclas) globosa, Forsk., Casto DE Elera, Catálogo sist. d. Fauna de Filipinas, 1II, 1896, p. 779, No.8.

Cryptodon globosum, Fonskíl, Heder, The Mollusca of Funafuti (Mem. Austral. Mus., III, pl. 8, p. 498), 1899. (Hindiy regards it $=\boldsymbol{L}$. ounm, Reeve). - Mollusca of Mast Head Reef, Queensland. (Proc. Linn. Soc. N. South Wales, vol. 31, 1906, p. 465).

Loripes globosa, Forsia, R. Bullex Newton, Pleistocene shells from the haised Beach Deposits of the Red Sea. (The Geological Magazine. New Ser., Dec. IV, vol. 7, 1900, p. 552).

Cryptodon globosum, Fonskíl, TATE and MAY, A revised Census of the mar. Moll. of Tasmania, 1901,

Lucina globosa, - W. H. DALL, Synopsis of the Lucinacea, 1901. p. 802. (DALr, writes: p. 432. The authors have the same opinion of the species as HEDLEY. "Hanley has shown that the Linnean edentula (1758) was probably that named by Reeve $L$. ovum, an oriental form described by Forskål under the specific name of globosa (1776), and with which, according to von Martens (1880), L. pila, Reeve is synonymous.")

Cryptodon globosus, - Evg. SmTH, Mar. Mollusca of the Maldive and Laccadive Archipelagoes, 1903, p. 626. - Journ. of Malacology, vol. XI, 1904, p. 25.

Cryptodon globosum, Fonskí, LAMr, Liste de Lamellibranches rec, p. M. Seurat aux illes Tuamotu et Gambier (Bull. du Mus. d'Hist. Nat. Paris, 1906, p. 213). LAMY regards it as identical with Inc. ovnm, Reeve.

As the above comparison shows, the erroneous view of Fonskå-Chemnitz's species globosa, originates from Audourn's wrong opinion of SAvigny's figure in "Iconographie d. Mollusques de l'Égypte;" afterwards are included, as synonyns, REEVE's species pila, tumida, and ovum, which species have nothing whatever to do with D. globosa, Forsk., consequently, wherever, in the literature globosa is given as $=L$. ovum, Reeve, it is doubtful which species is meant.

\section{Diplodonta (Joannisiella) oblonga, Hanl.}

Cyrenoida oblonga, Hanley, Catalogue of rec. biv. shells, 1856, p. 353, pl.15, fig. 6.

Ilysia - Soweribr, H. \& A. Adass, Genera of rec. Mollusca, II, p. 473.

Jounnisia - - W W. H. DaLL, Transact. Wagner Free Inst. Science. Philadelphia, III; 1895, p.545

Joannisiella - _ - _ The Nautilus, IX, 1895, p. 78.

- Synopsis of the Lucinacea, 1901, p. 792.

Sound of Koh Chang, 5 fathoms, soft clay (32/2). E. of Koh Mak, 20 fathoms, mud $(2, i y)$.

Long. 8--30 $\mathrm{mm}$.

Distribution:-- Philippines.

DALL has given Dipl. oblonga as the type for his genus Joamisiclla.

\section{Fam. Erycinidae.}

\section{Kellya lineata n. sp.}

(PI. III, Figs. 16-18).

'This shell is oblong ovate, white, convex and semitransparent. 'The umbo is siluated in the posterior part of the length of the shell, the anterior end is much 
prolonged, rounded. 'The valves are compressed in the middle, which makes the ventral side concave; in this concavity there occurs between the valves an oblong aperture through which the byssus protrudes. The surface is entirely covered with close-set, uniform, parallel, concentric, raised, longitudinal folds. The interior of the valves is glossy; the right valve has two triangular, prominent cardinal teeth, one on each side under the apex; there is just below the apex a small obtuse tooth in close proximity to the anterior tooth; on each side is a long lateral tooth, parallel with the upper margin and separated from it by a groove; these grooves receive corresponding long, lateral teeth which are situated directly upon the upper margin of the left valve; this valve has moreover two diverging cardinal leeth separated by a triangular space in which the ligament is located.

Long. $4.5 \mathrm{~mm}$., alt. $2.75 \mathrm{~mm}$., crass. $2.5 \mathrm{~mm}$.

Koh Kram, 30 fathoms (1). S. of Koh Samit, 20 fathoms, mud (2). Off Tung Kaben, 6 fathoms, mud mixed with sand (3). Between Koh Chuen and Kioh Chang, 15 fathoms, mud (1). Between Koh Kahdat and Koh Kut, 6-10 fathoms, clay mixed wilh sand, and shells (4). E. of Koh Mak, 20 fathoms, mud (1).

Singapore, $2-3$ fathoms (1).

I shall not enter more closely, in this place, into the question how far the genera Kellya and Erycina should be kept distinct, but it appears to me that the characters given by several authors as distinguishing characteristics are not especially valid. WennisufF ${ }^{1}$ even advises to retain the name Kellya for the recent and Erycina for the fossil forms (though, as is well-known, there are not a few fossil typical Kellya-forms). Stourczk ${ }^{2}$ puts Kellya $=$ Erycina. P. Fiscuen ${ }^{3}$ refers only the fossil forms to Erycina. Cossuans says regarding the genus Kellya in connection with Erycina: "Ia forme générale de la coquille peut elle-même servir, à première vue, à distinguer les deux genres: les Erycina sont orbiculaires et, (fuand elles ne sont pas équilatérales, c'est le côté antérieur qui est le plus long; au contraire, les Kellia sont plutôt subtriangulaires ou obrondes et le côté antérieur est généralement le plus court." According to this, my species Kellya lineata should be referred to Erycina; the dental formula also closely resembles that of the latter genus and several of the Erycina-species described by Cossmanx (loc. cit.) come, also in regard to the main characters, very near to $K$. lineata.

Kellya cycladiformis, Desh.

Erycina Cycladiformis, Deshayes, Traité élément. de Conchyliologie (1839-53), pl. 11, figs. 6-9.

- - _ _ Proc. Zool. Soc. London, XXIII, 1855, p. 181, No. 2.

Kellia cycladiformis, ㄴ HuTtos, Manual of the New Zealand Moll., 1880, 1. 157.

1 Die Conchylien d. Mittelmeeres, I, 1867, p. 180.

2 Palcontologia Indica. Cretaceous fauna of the Southern India, III. The l'elecypoda, 1871, p.263.

3 Manuel de Conchyliologie, 1887, p. 1025.

4 Annales de la Soc. roy. Malacolog. de Belgique, XXil, 1887, p. 61.

D. K. D. Vidensk, Selsk, Skr., 7. Rekke, maturvidensk, of mathem. ASis. V. 3. 
W. of Koh Chuen, soft clay and mud (1/2).

Long. $6.5 \mathrm{~mm}$.

Distribution:- North Australia, Mast Head Reef (Queensland), Sydney and Port Jackson, Flinders (Victoria), New Zealand.

With regard to the generic name Kellya, it was established by 'Tunton in 1822 as Kellia. JeFfrers says that the genus is named after "the Rev. J.M. O'Kelly of Dublin," consequently, it can neither be written Kellia, nor (as Bucouor, DautzenBERG and Dortevs write) Kellyia, ${ }^{1}$ but must be written Kellya.

Kellya rotunda, Desh.

Erycince rolunda, Desiayes, Proc. Zool. Soc. London, XXII, 18.5, p. 181, No. 1.

Kelliu - - Avgrs, Proc. Zool. Soc. London, 1867, p. 937, No.98.

- - - $\quad$ - var., Eng. Smith, lRep. on the Lamellibranchiata of the Challenger Exped.,

p. 202 , pl. XI, fig. 5 .

- - - Sowerby, Marine Shelis of South Africa, 1892, p. 62, pl. 4, fig. 93.

- Pritghand and Gateiff, Proc. 1R. Soc. Victoria, XVII, 1904, p. 225.

Koh Kram, 30 fathoms (2). Between Koh Mesan and Cape Liant, 9 falhoms (1). Between Koh Mesan and Koh Chuen, 25-38 fathoms, stones and shells (13).

Long. 3-10 mm.

Distribution: - Moreton Bay, Newcastle (New South Wales), Sydney and Port Jackson, Holdfast Bay (South Australia, Bril. Mus.), Bass Straits. (Sowenby records it from Port Elizabeth and EDg. Sulth from Port Alfred (Cape Colony) ${ }^{2}$ ).

Probably the forms from South Africa which Sowerby and Eog. Surtu have had before them do not belong to Deshayes's species from South Australia. Soweriz's figure does not agree exactly with Desnayes's diagnosis, but as the figure is very bad, nothing definite can be concluded on this basis. EDG. Sirtu regards $K$. rotunda, Desh., to be "doubtfully separable" from $K$. suborbicularis, Mtg., "and in this he is undoubtedly right. Among the specimens collected in the Gulf of Siam both Desmayes's type-form (from Moreton Bay), and the variety Erig. Surtir describes and ligures from the Challenger Expedition, are to be found.

\section{Kellya rosea $\mathrm{n}$. sp.}

(Pl. III, Figs, 19--20).

This species is almost circular in outline. It is thin and of a dull glass-like consistency, pink, gently arching, with fine concentric lines of growth, not particularly convex. The umbones, which are situated at about the middle of the length of the shell, are slightly elevated above the hinge-line. 'The hinge consists of two cardinal teeth in the left valve and a single one in the right. 'The right valve has also an oblong, flat, triangular lateral tooth, parallel with the hinder

1 See W. H. D.tl. Transact. Wagner Free Inst. Sc. Philadelphia, vol. III, 1895, p. 563.

2 Journal of Malacology, vol. XI, 1904, 1). 26.

3 Annals \& Mag. Nat. Hist., (6) X, 1892, p. 132. - Proc. Malac. Soc. London, V, 1902, p. 163. 
dorsal margin, from which it is separated by a narrow groove which receives a corresponding tooth in the other valve. The internal ligament is small and is located just beneath the apices and behind the cardinal teeth in both the valves. The interior is dully pink.

Long. $9 \mathrm{~mm}$., alt. $\$ .5 \mathrm{~mm}$., crass. $5 \mathrm{~mm}$.

Between Koh Mesan and Koh Chuen, 25-38 fathoms ( $8 / 2)$.

Kellya rosea somewhat resembles Kr. rotunda, Desh., but is easily distinguished from it by its pink colour, and by the absence of the glossy iridescent surface of $\boldsymbol{K}$. rotunda; neither is it so convex, and the valves are more gently and regularly rounded than in rotunda. For the rest, the species belonging to the genus Kellya vary considerably; not only do young and old individuals often difier greatly in form, but also full-grown specimens may often be very different in both form and outline. Young individuals of $K$. rosea (and also of other species) are usually longer in proportion to their height, and the ventral margin is straighter, than is the case in larger specimens.

\section{Kellya vitrina n. sp.}

(Pl. III, Figs. 21-22).

This little species is hyaline, and somewhat silver-shining, thin, rather flat and triangular in form. The umbones are situated at about the middle of the longitudinal axis and the upper margin slopes gradually down on each side. 'The anterior and the posterior ends are rounded, the ventral side is fairly straight, and somewhat concave in the middle. The surface is smooth and ornamented with fine lines of growth; the concavity menlioned above extends from the ventral side upwards beyond the middle of the valves as a slight depression and disappears gradually towards the umbones. The interior of the valves is highly glossy, the hinge is composed of a single little posterior cardinal tooth in the right ralve and two strong diverging teeth in the left, between which the internal ligament is situated. The right valve has, moreover, two long lateral lamella, one on each side, parallel with and closely along its dorsal margin; and in the left valve is one solitary, very slightly developed lateral lamella directly upon the anterior dorsal margin.

Long. $2.5 \mathrm{~mm}$., alt. $2 \mathrm{~mm}$., crass. $1 \mathrm{~mm}$.

Koh Chuen, 30 fathoms (1).

In spite of its small size this characteristic species is undoubtedly full-grown; in oulline it somewhat resembles Pythina Deshayesiana, Hinds.

\section{Kellya elongata n. sp.}

(Pl. 111, Figs. 23-24).

This species is oblong-ovate and convex, and opargue white in colour. The umbones which are situated towards the anterior end are slightly elevated above the hinge-line and terminate in obtuse, circular, glossy, shield-like bosses the embryonic 
shell). The posterior side is somewhat higher than the anterior, and both are gently rounded towards the ventral side which is straight. The very concave valve is flattened in the middle, so that towards the sides rounded keels are formed in passing to the anterior and posterior ends. The surface is somewhat glossy, and is rough owing to irregular, concentric, coarse lines of growth. The interior of the valve is white and slightly glossy. In the left valve, just under the apex, are two cardinal teeth of which the anterior one is the smaller; the internal ligament is situated inmediately behind the posterior tooth. There is also a small posterior lateral tooth which is very slightly developed.

Long. $6 \mathrm{~mm}$, alt. $3.5 \mathrm{~mm}$, crass. $3.7 \mathrm{~mm}$.

South of Koh Tulu, 10 fathoms, mud mixed with sand (1/2).

Unfortunately, the Danish Expedition obtained only the left valve described above; it is, however, very characteristic in form.

\section{Kellya lilium n. sp. \\ (Pl. III, Figs. 25-26).}

The shell is oblong-ovate, white, semitransparent, dully glossy, rather flat and thin. The upper margin slopes from the umbo gradually down on both sides, most sharply towards the posterior end, which is somewhat more acutely rounded than is the anterior. The ventral side is slightly convex. The umbones, which are not especially prominent, are situated somewhat towards the posterior end. At the apex the embryonic shell remains as a small, globular, smooth tubercle. Upon the surface the lines of growth appear as irregular, coarse strix. In the shell-substance are seen, both internally and externally, close-set, fine lines which radiate from the umbo. The interior of the valves is white and glossy. The hinge-teeth are very slightly developed in comparison to the size of the valve; under the apex and somewhat in front of it there is, in the right valve, a well-developed, prominent, flat, triangular and acute cardinal tooth, and a small posterior tooth, more slightly developed; between these two teeth there is a triangular pit. The left valve has an anterior, long, rather stoul, triangular tooth, at the hinder border of which, just below the beak, is a small insignificant rudimentary tubercle (in oller hellyaspecies this is developed into a fairly large looth). Upon the posterior upper margin there is a rather small triangular looth, at the hinder border of which the ligament is attached; between the cardinal teeth there is a triangular space. The muscular sears are fairly distinct.

Long. $13 \mathrm{~mm}$., alt. $9 \mathrm{~mm}$, crass. $5 \mathrm{~mm}$.

The sound of Koh Chang, 3-5 fathoms, soft clay (3/2). N. of Koh Kut, 10 fathoms, mud $(1 / 2)$ "

In outline and external appearance this species somewhat resembles Abra alba, Wood. 


\section{Montacuta costata 11. sp.}

(II. 111, Fig. 27).

This litte species is oblong-ovate and rather flat, white, semilransparent, somewhat glossy and provided with a thin yellowish epidermis. The anterior end is regularly rounded, the posterior end forms a somewhat sharp angle with the dorsal side, and then slopes in a straight line down towards the ventral side, with which it forms a roundly-acute angle; a sharp keel extends from the latter across the shell up towards the apex. The ventral margin is rather straight. The umbones which are not very prominent, are situated towards the posterior" end. "The surface is smooth around the apex, but gradually slight, concentric costa are scen to appear, which upon the rest of the shell (about $1 \mathrm{~mm}$. from the top right down to the ventral margin) occur as numerous, close-set, parallel, uniform, rounded ridges; at the keel mentioned above they turn abruptly and ascend parallel to each other straight up towards the sloping posterior side of the upper margin. The interior of the valves is white and glossy. The left valve has two erect lamellar very divergent long teeth, of which the posterior is rather more strongly developed; they are separated by a broad triangular space, and stand out freely from the outer margin. The shell-margin is somewhat thickened, especially along the ventral side.

Long. $3 \mathrm{~mm}$., alt. $1.7 \mathrm{~mm}$., crass. $1 \mathrm{~mm}$.

West of Koh Kut, 30 fathoms, sand and mud (1/2).

Unfortunately only a single left valve of this little species was obtained, and it is perhaps not full-grown; when complete specimens are at hand, it will be proved whether I am right in referring it to the genus Monlacuta. With regard to the generic name Montacuta, it was given in 1819 to this group of the Lamellibranchiata by TunTon, under the form of Montacuta (after the zoologist GEolige Montagu). In 1828 Fruming employed the generic name Montagua for a group of Aeolidae, but RUD. BERGH afterwards (1864) replaced this by the name Cratena; in 1825 Desmarest employed the name Montagua for a crustacean, but this was after" wards obliged to give place to Callianassa, Leach. In 1852 LEacir proposed the name Montagua for a group of Trochus-forms (= Jujubinus, Monterosato). Bronn, and later Bucouoy, Dautzenberi and Dollfus, and also Layr, use the name Montaguia for this group of Lamellibranchiata," but according to the rules for zoological nomenclature now in force this is not admissible, it should be Montagua, if it could be used at all.

\section{Montacuta venusta n. sp.}

(Pl. III, Figs. 28-29).

This species is oblong-ovate, donaciform, rather flat and white. The umbones are siluated towards the front end, in the anterior third of the shell. 'The anterior end slopes in a slight curve abruptly down from the apex towards the ventral

1 P. Fischer says also (Manuel de Conchyliologie, p. 1027) that Montaguia is the most correct form of the name. 
side, with which it forms a roundly-acute angle. The ventral margin descends towards the posterior end, at which point it is most convex. The upper margin slopes in a rather straight line down towards the somewhat pointed, drawn-out posterior end. The umbones terminate in a smooth, glossy, rounded, nodular apex, upon which the small, round embryonic shell is found. Below this and radiating from the umbo, an exceedingly close-set, fine, raised network extends over the whole surface towards the outer sides. The threads of the network divide often, especially towards the anterior and posterior ends, and are separated from each other only by very fine grooves. The concentric lines of growth are coarse, irregular and fairly: prominent. 'The interior of the shell is dully white, and glossy only towards the outer margins; the left valve has two cardinal teeth, of which the hinder is the larger, and is triangular and tapering, separated from the upper margin of the shell by a deep groove; the other tooth is pointed near its commencement and forms a rather long, laminar ridge parallel with the upper margin. Between the divergent cardinals under the umbones is a triangular space which receires the internal ligament.

Long. 9 $\mathrm{mm}$., alt. $6.5 \mathrm{~mm}$., crass. $4 \mathrm{~mm}$.

North of Koh Kut, 10 fathoms, mud $(1 / 2)$.

Unfortumately only a single left valve was obtained of this beautiful species, the ray-like surface-sculpture of which is especially characteristic.

\section{Montacuta (Tellimya) japonica, A. Ad.}

Tellimya japonica, d. Andus, Anu. and Mag. Nat. Hist., 1862, p. 225.

- Juponica, - Dexier, Index moll. mar. Japon., 1882, p. 219.

The sound of Koh Chang, 3-5 fathoms, soft clay $(12 / 1)$. W. of Koh Chang, 20 fathoms, mud ( $1 / 2)$. Koh Kahdat, 4-5 lathoms, sand and stones (1/2).

Long. $1.75-5.75 \mathrm{~mm}$. (long. $5.75 \mathrm{~mm}$, alt. $35 \mathrm{~mm}$, crass. $2.5 \mathrm{~mm}$.).

Distribution: - Japan.

The specimens from the Gulf of Siam correspond closely to ADAM's diagnosis (unfortunately he does not give a figure of his species), but when he says that: "This species is more transversely oblong than T. bidentata from the seas of Europe, and the anterior side is much shorter," then only the first part of the above passage agrees with my observations, but with regard to the anterior end, it is almost of the same length as in $M$. bidentata. The form of my specimens of Montacula japonica agrees therefore, in its main features, most closely with that of $\mathbf{M}$. ferruginosa, Montagu; but like all other Montacuta-species, $M$. japonica probably varies somewhat both in form and outline.

\section{Montacuta (Tellimya) paula, A. Ad.}

Pythina panla, A. Adsis, Proc. Zool. Soc. London, XXIV, 1856, p. 47, No. 3.

Montacula paula, - Evg. SurT, Rep. on the Lamellibranchiata of the Challenger Exped., p. 203.

Pyllina -

Annais and Mag. Nat. Hist., 6 Ser, VIII, 1591, p. 230.

Pylhina peculiaris, - Proc. Zool. Soc. London, XXIV. 1856, p. 47, No. 4. 
The strand off the mangrove at the station on Kols Chang (1). Off Kioh Kut, 5 fathoms (2). Coast of Koh Kong (6).

Long. 3-7 $\mathrm{mm}$.

Distribution:- Ceylon, Aden (Shopiand). - South of New Guinea, Torres Strait.

Montacuta (Tellimya) triangularis, A. Ad.

Pythina triangularis, A. Adsws, Proc. Zool. Soc. London, XXIV, 1856, p. 47, No. 5.

- - - _ - Evg. Sirtr, Annals and Mag. of Nat. Hist., vol. VIII, 1891, 1). 231, No. 8.

Mactra nucleus, REeve, Conchol. icon., VIII, Mactra, Sp. 102 (non M. nucleus, Coniun, Journ. Acad. Nat. Sc. Philadelphia, VI, part 2, 1830, p. 258, No. 3).

Koh Kahdat (1/2). S. of Kol Kahdat, 8-10 fathoms, mud (i/y). N. of Koh Kut, 10 fathoms, mud $\left({ }^{1 / 3}\right)$.

Long. 5-7 mm.

Distribulion:- Manilla (A. Adans).

Kellya subsinuala, Lischke, resembles the present species very much in form.

\section{Montacuta (Tellimya) variabilis n. sp.}

(Pl. III, Figs. $30-32$ ).

This species is triangular in form, dully white, semitransparent, rather thin and flat. The umbones, which are situated in the front half of the length of the shell, sometimes quite anteriorly, sometimes nearer to the middle of the shell, are pointed and terminate in a smooth, round tubercle; the embryonic shell is very distinct. From the umbones the upper nargin slopes abruptly downwards on both sides. The ventral margin is sometimes convex, sometimes straight, and sometimes somewhat concave. The concentric lines of growth make the surface rough and are sometimes coarse. The interior of the valves is glossy, and there are, in the left valve, two divergent, llat, pointed, triangular, highly prominent cardinal teeth, separated from the upper margin by a groove; between these teeth there is a triangular space in which are placed the cartilage and the ossicle, these fit into a corresponding triangular space in the hinge plate of the right valve. Directly upon the upper margin of the valve and close to the hinge plate there is in the right valve, on each side, a slightly developed lateral tooth, of which the anterior is the larger; these teeth fit into the groove between the teeth and the upper margin of the left valve.

Long. $4 \mathrm{~mm}$., alt. $3 \mathrm{~mm}$., crass. $2 \mathrm{~mm}$.

The Guif at the south end of Koh Chang (6).

As may be seen from the above diagnosis, this species varies highly in form, a fact which is undoubtedly due to its habitat and mode of living (commensalism?); the characteristic triangular form is common to all the individuals. I have figured on PI. III, Figs. 30-31 the two most divergent forms, which limit the variation of the specimens obtained. 


\section{Montacuta (Tellimya) rudis $\mathrm{n} . \mathrm{sp}$.}

(Pl, III, Figs. 33-34).

'This shell, which is oblong-ovate, is, especially in the anterior half, somewhat ventricose; it is white and rather thin. Anteriorly the shell is truncated, but posteriorly it is pointed. 'The ventral side is straight; across the middle from the umbones to the ventral margin the valves are somewhat depressed. The umbones are situated in the anterior half of the shell, the apices are glossy, smooth and pointed. Upon the surface, which is covered with a yellowish epidermis, the rough and coarse concentric lines of growth may be seen; in addition to these are distributed, over the whole surface, numerous line or coarse grains and tubercles which make the valve-surface peculiarly rough and uneven. The interior of the valves is glossy, the left valve has in it, separated from the upper margin by a groove, lwo diverging, triangular, compressed, acute cardinal teeth, between which are placed the ligament and the ossicle; these fit into a triangular pit just below the apex of the right valve; close to this pit and directly upon the upper margin there is on bolh sides in the right valve an oblong lateral fold, which fits into the corresponding groove above the cardinal teeth of the left valve. The muscle inpressions are large and very conspicuous.

Long. $7.5 \mathrm{~mm}$., alt. $5 \mathrm{~mm}$. , crass. $3 \mathrm{~mm}$.

The north side of Koh Chang, 12 fathoms, in old coral blocks (1).

The peculiar surface is characteristic of this species, which lives in holes. in coral blocks and which therefore, as is the case with all the forms which are found in such localities, is subject to changes in form according to the locality which it may chance to inhabit.

\section{Lepton sp.}

A single, somewhat damaged, left valve of a Lepton was taken in the sound of Koh Chang, in 3-5 lathoms, on a soft muddy boltom; it should be placed near to L. trigonale, Tait, but differs from it. In the British Museum there is a specimen of an undetermined Lepton from Port Lincoln which exactly agrees with my shell from the Gulf of Siam.

\section{Fam. Galeommidae.}

\section{Galeomma angusta, Desh.}

Galeomna angusta, Drsunvs, Proc. Zool. Soc. London, XXIII, 1855, p. 170, No. 7.

Sowndy, Thesaurus Conchyl., III, p. 174, No. 8, pl. 234, fig. 10.

Solverhy in Revve, Conclıol. icon., vol. 19, Guleonma, Sp. 3.

Coast of Lem Ngob, low tide, stones (150 specimens). Gulf at the south end of Koh Chang (7). Koh Chang, very low tide, stones (5). North end of Koh Chang 1 fathom, old coral blocks (2). 
Long. $3-10.5 \mathrm{~mm}$.

Distribution:- Philippines.

I think that G. chloroleuca, Desh, can scarcely be separated from G. angusta, Desh., as a distinct species; I have compared DesHayes's original specimens of these species in Cumng's collection in the British Museum, and am of opinion that they are without doubt identical.

Galeomma argentea, Desh.

Galeomma argentea, Deshayes, Proc. Zool. Soc. London, 1855, p. 169, No. 6. Sowerri, Thesaurus Conchyl., III, p. 174, No. 3, pl. 234 , figs. $13-11$. Sowerby in Reve, Conchol. icon., XIX, 1874, Galeomma, Sp. 7.

North end of Koh Chang, 1 fathom, old coral blocks (1).

Long. $6 \mathrm{~mm}$.

Distribution:- Philippines.

Galeomma macrochisma, Desh.

Galeomma macrochisma, Deshayes, Proc. Zool. Soc. London, 1855, p. 171, No. 12.

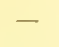

Bidang, 9 fathoms, mud and shells (1).

Long. $10 \mathrm{~mm}$.

Distribution:- Philippines.

\section{Scintilla hyalina, Desh.}

Scintilla hyalina, Deshayes, Proc. Zool. Soc. London, 1855, p. 180, No. 34. Sowerry, Thesaur. Conchyl., III, p. 179, No. 33, pl. 234, figs. $23-24$. Sowerby in ReEve, Conchol. icon., XIX, Scintilla, Sp. 30.

W. of Kolı Kam, 5 fathoms, gravel (1). Coast of Lem Ngob (5). Koh Chang, stones, low tide (1). North end of Koh Chang, 1 fathom, old coral blocks (1).

Long. 4-7 $\mathrm{mm}$.

Distribution:- Torres Strait (Deshayes, Melvill \& Standen).

\section{Scintilla anomala, Desh.}

Scintilla anomala, Desinayes, Proc. Zool. Soc. London, 1855, p. 181, No. 37.

Sowerny, Thesaur. Conchyl., III, p. 179, No.38, pl. 234, figs. 25-26.

Angas, Proc. Zool. Soc. Loudon, 1867, p. 928, No. 102.

$\begin{array}{ll}- & - \\ - & -\end{array}$ Sowerizy in ReEve, Conchol. icon., XIX, Scintilla, Sp. 37.

Coast of Lem Ngob (1).

Long. $4 \mathrm{~mm}$.

D istribution:- Philippines (Deshayes). Port Jackson (Angas).

Deshayes records "Ins. Samar (Philippines)" as the locality for his typespecimens in the Cuming collection; on the other hand, Angas (loc. cil.) says: "M. DeshaYes's types in the Cumingian collection are from Borneo." 


\section{Scintilla candida, Desh.}

Scintilla candida, Deshayes, Proc. Zool. Soc. London, 1855, p. 177, No. 17.

$-\quad-\quad$ Sowerby, Thesaur. Conchyl., III, p. 177, No. 17, pl.235, fig. 33.
-

Koh Kahdat, 1 fathom, sand (3). Koh Kahdat, 1-2 fathoms, corals (2). North end of Koh Chang, 12 fathoms, old coral blocks (3).

Long. $25-11.5 \mathrm{~mm}$.

Distribution:- Gulf of Manaar. - Philippines.

\section{Scintilla Philippinensis, Desh.}

Scintilla Philippinensis, Desuayes, Proc. Zool. Soc. London, 1855, p. 176, No.14.

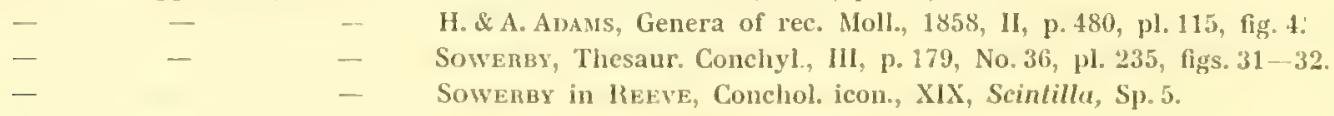

Koh Kahdat, 1 fathom, sand (1).

Long. $95 \mathrm{~mm}$., alt. $6 \mathrm{~mm}$.

Distribution:- Philippines, Sorong (Tapparone Canefri).

Scintilla hydatina, Desh.

Scintilla hydatina, Deshartes, Proc. Zool. Soc. London, 1855, p. 177, No. 19.

- - Sowenby, Thesaur. Conchyl., III, p. 180, No. 39, pl. 235, figs. 56 - 57.

- $\quad$ - Sowerby in IReve, Conchol. icon., XIX, Scintilla, Sp. 38.

Coast of Lem Ngob, low tide, stones (many specimens).

Long. up to $6 \mathrm{~mm}$.

Distribution:- Philippines.

S. Alberti, Smith, ${ }^{1}$ from Torres Strait is very closely related to the present species.

The accompanying figure drawn from a sketch of Scintilla hydatina, Desh., made by Dr. 'Th. Mortensen from living specimens collected at Lem Ngob, shows that the animal agrees in many points with Mößus's figure (v. Martens, Die Mol-

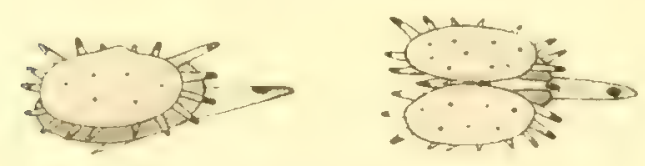

Scintilla hydatina, Desh. lusken d. Maskarenen u. Seychellen, Berl. 1880, pl. 21, fig. 10) of Scintilla aurantia, Lam. The mantle, which covers both the valves, is pale yellow (the colour being due to numerous small, pale yellow drops which are present in the mantle), and bears many, comparatively long papilla, which are contractile; they are smallest in the middle of the valves and become larger towards the margins, where they reach a length of about $2 \mathrm{~mm}$. 'lhey do not agree in form with those figured by MöвIus

"Report on the zoolog. collections made in the Indo-Pacific Ocean during the voyage of H. M. S. "Alert," 1881-82, Lond. 1881, p. 107, pl. 7, fig. G. 
in S. aurantia, but are apparently cylindrical; each is deep red at the tip, the small papilla in the middle of the valves being the palest in colour. There is also a red spot upon the foot, about $1.5 \mathrm{~mm}$. from its end.

\section{Fam. Tellinidae.}

\section{Tellina (Tellinella) Deshayesi, Hanl.}

Tellina Deshayesii, HanleY, Proc. Zool. Soc. London, XII, 1844, p. 148.

$\begin{array}{llll}- & - & - & \text { Sowerbx, Thesaur. Conchyl., I, p. 223, No. 2, pl. 57, fig. } 66 . \\ - & - & - & \text { Reeve, Cunchol. icon., XVII, Tellina, Sp. 200. } \\ - & \text { - } & - & \text { V. Bertin, Révision d. Tellinidés, p. 251, No. 52. } \\ - & \text { Deshayesi, } & - & \text { Cnosse et Fischen, Journ. de Conchyl., vol. 40, 1892, 11. 76. }\end{array}$

(Non Tellina Deshayesii, P. Carpenten, Proc. Zool. Soc. London, 1856, p. 160, Hab. in Sinu Panamensi).

Gulf of Siam, west coast of Cambodge (PAvie).

Distribution:- Aden (Shopland), Red Sea (Hanley (?), V. Bentin).

The Danish Expedition to Siam collected no specimens of this species.

\section{Tellina (Tellinella) Spengleri, Martini (Chemn.).}

Das Elfenbeinerne Schiffein oder Navet, L. SpengLen, Beschäftig. d. Berlin. Gesellsch. Naturf. Freunde, I, 1775, pp. 387--94, pl. 9, figs. 1-3.

Dic Spenglerischen Dïnnmuschel, Marrini, Beschäftig. d. Berlin. Gesellsch. Naturf. Freunde, 1, 1775, p. 394. Tellina Spengleri, Mantivi in Cinemntz, Conchyl. Cabin. VI, 1782, p. 98, pl. 10, figs. $88-90$.

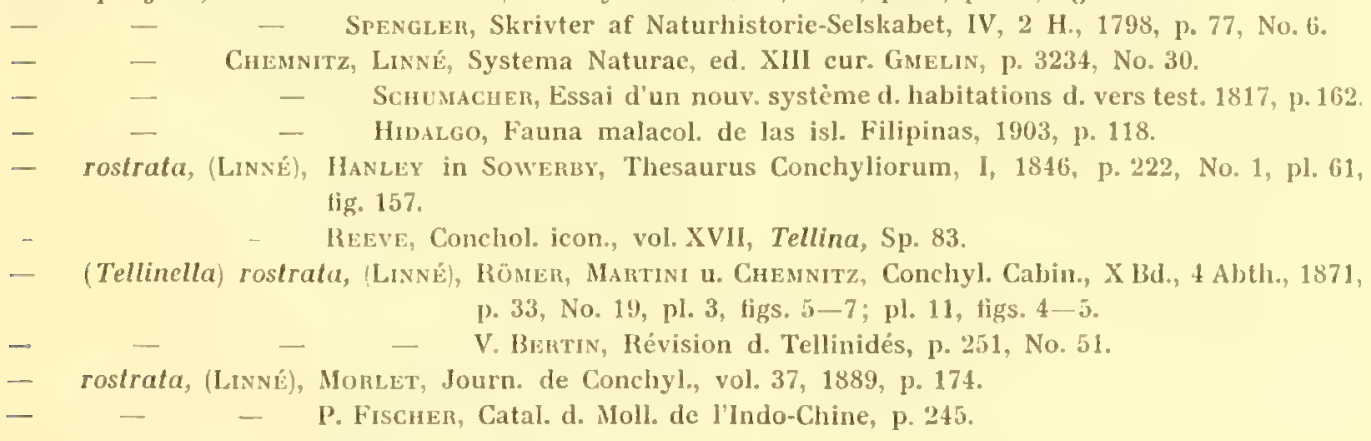

Hatien (Gulf of Siam) L. Morlet.

The Danish Expedition to Siam collected no specimens of this species.

Distribution:- Malacea, Nicobars, Bay of Bengal, Ceylon, Madras, Mauritis(?). - Cochin China, Philippines, Moluceas, Banka, Java.

LinNé, in spite of HANLEy's assertion in "Ipsa Linnæi Conchylia," has certainly" not been clear in his judgment of his species $T$. rostrata; he has evidently confused T. vulsella, T. Spengleri and T. perna under this name; therefore, I have had no hesitation in following Hidalgo's example and employing Martinis (Chemitz's) name T. Spengleri for the present species, T. Spengleri being both described and figured very clearly. SPENGLER already, both in his original collection (which is preserved in the Zoological Museum of the University of Copenhagen) and in his 
description of the genus Tellina, distinctly dillerentiates between T. rostrata L. (=vulsella, Ch.) and T. Spengleri.

\section{Tellina (Tellinella) pulcherrima, Sow.}

Tellina pulcherrima, Sowerny, Catal, of shells in the collect, of the Earl of Tankerville, 1825, Appendix, p. III, No. 184, pl. 1, fig. 1.

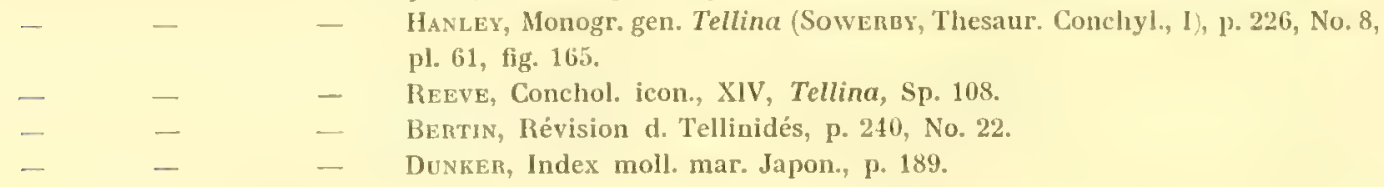

North of Koh Kahdat, 4-5 fathoms, coarse sand (1). Between Koh Kahdat and Koh Kut, 6 fathoms, sand mixed with mud (1/2). W. of Koh Kut, 15 fathoms, $\operatorname{mud}(1 / 2)$.

Long. 29-39 $\mathrm{mm}$.

Distribution:- Singapore, Banca Strait, Philippines, Japan, Mast Head Reel (Queensland).

\section{Tellina (Tellinella) rugosa, Born.}

Tellina rugosa, Bolin, Index rer, natur. Mus. Caesar. Vindohon., I, 1778, p. 18. - 'Testacea Mus. Cresar. Vindobon., 1780, p. 29, pl. 2, figs. 3-4.

- Chemnitz, Conchyl. Cabin., VI, 1782, p. 81, pl. 8, fig. 62.

- - - Hanley, Monogr. of the gen. Tellina (Soweruy, Thesaur. Conchyl., I), p. 267, No. 82, pl. 64, fig. 238.

- (Tellinella) rugosa, Bors, Römer in Martinı u. Chemnitz, Conchyl. Cabin., X, 4 Abth., p. 36, pl. 2, fig. 1 ; pl. 11, figs. $6-7$.

- rugosa, Bonn, Reveve, Conchol. icon., XVII, Tellina, Sp. 36.

- (Tellinella) rugosa, Borv, Bertin, Révision d. Tellinidés, p. 242, No. 29.

Koh Mak, sandy coast ( $(2 / 2)$.

Long. 29-37 $\mathrm{mm}$.

Distribution:- Ceylon, Karachi, Hulule Isl., Gulf of Aden, Red Sea, Suez, Seychelles, Mauritius, Zanzibar, Querimba Isls. - Philippines, Yaeyama (Loo Choo IsIs.), Sulu Isls., Java, Ceram. Banda Isls., New Guinea, Moreton Bay (Queensland), New Galedonia, Mariannes, Lifu, Viti Isls., Funafuti (Ellice Isls.), Samoa Isls., Sandwich Isls., Raratonga, Opara, Tahiti, Mangareva and Akamaru.

\section{Tellina (Tellinella) Hungerfordi, Sow.}

Telline IInngerfordi, Sowerur, Proc. Malacolog. Soc. London, I, 1894, p. 159, No. 23, pl. 12, fig. 22.

Off Koh Kam, 10 fathoms, gravel (1/2). Koh Chuen, 30 fathoms (1/2). S. of Koh Kahdat, 8-10 fathoms, mud ( $/ 2)$. Between Koh Kut and Koh Kahdat, 10 lathoms, shells $(2 / 2)$.

Long. $4-7 \mathrm{~mm}$.

Distribution: - Singapore (2-3 fathoms, coral reef, and in shallow water; $5 / 2$ valves, Danish Exp. to Siam, and Sv, Gad). Hong Kong (Sowerby). 
SowErby states in his diagnosis: "laterales indistincti," but this is not the case in my specimens, in which the lateral teeth in the right valve are very well developed; the anterior stands close to the cardinal teeth.

\section{Tellina fabrefacta, Pilsbry.}

Tellina fabrefacta, Pilsbry, Proc. Acad. Nat. Sc. Philadelphia, vol. 56, 1901, p. 555, pl. 41, figs. $11-12$.

- - - Hedery, Proc. Linn. Soc. New South Wales, vol. 31, 1906, p. 478.

Between Koh Rin and Cliff Rock, 15 fathoms (2/8).

Long. $5 \mathrm{~mm}$.

Distribution:- Singapore, shallow water (long. $5.5 \mathrm{~mm}$.), Sv. GaD; Hirado, Hizen (Japan), PILSiri; Mast Head Reef (Queensland), Hedley.

\section{Tellina (Arcopagia) capsoides, Lam.}

Tellina capsoides, Lamanck, Hist. nat. d. anim. s. vert., V, 1818, p. 531, No. 44. - éd. 2, VI, 1835, p. 205, No. 44.

- Capsoides, - Hanley, Monogr. of the gen. Tellina (Sowelus, Thes. Conchyl., I), p. 268, No. 85 , pl. 62 , fig. 185 .

- capsoides, - ReEve, Conchol. icon., XVII, Tellina, Sp. 183.

- (Tellinella) capsoides, Lamarč, Römer in Martinı \& Chemitz, Conchyl. Cabin., X Bd., 4 Abth. p. 48 , No. 28 , pl. 14, figs. $1-3$.

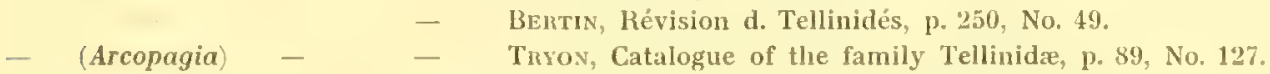

The strand off the mangrove at the station on Koh Chang, shallow water (3). Long. $26-36 \mathrm{~mm}$.

Distribution:- Andamans, from Goa to Bombay, Karachi, Gulf of Suez (Mac Andrew), Natal coast (Sowerby). - Philippines, Hong Kong, Giabu Lengan (Aru), "Australia", Saint-Pierre, Saint-François, Viti IsIs.

Tellina negrosiensis, V. Bertin, judging from the description, no doubt scarcely differs specifically from the present species.

Tellina (Arcopagia) Siamensis, v. Mart.

Tellina (Arcopagia) siamensis, v. Mantens, Proc. Zool. Soc. London, 1860, p. 18.

Siamensis, v. MakTENS, Malacozool. Blätter, 1873, p. 175

Arcopagia siamensis, - V. BERTrN, Révision d. Tellinidés, p. 326, No. 39.

Tellina (Arcopagia) Siamensis, v. Mantexs, P. Fiscrer, Moll. de l'Indo Chine, p. 245.

- - - - - Melvill \& Standen, P'roc. Zool. Soc. London, 1906, p. \$22.

- perplexa, Römer (non Hanley), Mantini u. Chemnitz, Conchyl. Cabin., X Bd., 4 Abth., p. 49, No. 29, pl. 14, figs. 4-6 (fide E.v. Martens). ${ }^{1}$

Siam (Mr. Моунот).

The Danish Expedition to Siam collected no specimens of this species.

${ }^{1}$ Malakozoolog. Blätter, 1873, p. 168. Although E. v. MARTENs in the paper in question states that lie thinks Kömer's figure and description of $T$.perplexa agree with his $T$. Sianensis and not with "der" ächte perplexa Hanl.," yet in "The Journal of the Linnean Society," vol. 21, 1887, p. 215, lie refers to the same figure in the list of synonyms under $T$. perplexa, Hanley. 
Distribution:- Karachi (Melvile \& Standen). Pilsiry records that Fro STEArns took "a short form" of this species at Japan (Inland Sea).

T. capsoides, Lam., T. ostracea, Hanl, and T. perplexa, Hanl., according to v. Martens, are very closely allied to the present species.

\section{Tellina (Arcopagia) elegantissima, Sm.}

Tellina (Arcopagia) eleganlissima, EDG. SMrn, Report on the Lamellibranchiata of the Cliallenger Exped., 1885 , p. 105 , pl. 4, lig. 3.

Koh Lan, 30 fathoms, mud (1/2). Gulf of Rayong, 7-10 fathoms, sand and mud (2). S. of Koh Mak, 5-6 fathoms (2). Between Koh Kut and Koh Kahdat, 10 fathoms, shells $\left({ }^{2} / 2\right)$. Same locality, 6 fathoms, mud mixed with sand $\left({ }^{3 / 2} / 2\right)$. W. of Koh Kut, 15 fathoms, mud (1/2). Koh Kahdat, 1-5 fathoms, sand (1).

Long. 10-18 $\mathrm{mm}$. (long. $18 \mathrm{~mm}$, alt. $15 \mathrm{~mm}$., crass. $9 \mathrm{~mm}$.).

Distribution:- Torres Strait.

Tellina (Arcopagia) habrotima, Melvill, ${ }^{1}$ from Angrias Bank, Arabian Sea is very closely related to the present species.

\section{Tellina (Arcopagia) carnicolor, Hanl.}

Tellina carnicolor, Hanliy, Soweruy, Thesaur. Conchyl, 1, 1s46, p. 263, No. 75, pl. 56, fig. 15.

- - - ReEve, Conchol. icon., XVII, Tellina, Sp. 126.

- (Arcopagia) carnicolor, Handey, Rösdr in Mantixi u. Cheminz, Conchyl. Cibin., X Bd., 4 Abth., p. 85.

Arcopagia carnicolor, Hancey, V. Bertun, Révision d. Tellinidés, p.322, No. 16.

Tellina incarnata, HANtiry, Proc. Zool. Soc. London, XII, 1844, p. 68.

- Strangei, Disnayes, Proc. Zool. Soc. London, XXII, 1854, p. 362, No. 206 (fide Ling. A. SurTi).2

- corbis, Sowekby, RaEve, Conchol. icon., XVII, Tellina, Sp. 127 (tide EDg. A. SMrti).

N. of Koh Kam, 5 fathoms, gravel (1). Koh Mesan, 15 fathoms, slones (1/2). Between Koh Mesan and Cape Liant, 5-9 fathoms (1/2). W. of Koh Kut, 15 fathoms, mud (21/9).

Long. 4-13 $\mathrm{mm}$. (long. $13 \mathrm{~mm}$, alt. $10 \mathrm{~mm}$., crass. $5 \mathrm{~mm}$.).

Distribution:- Andamans, Maldive Archip. - Philippines, New Caledonia, New Zealand (T. Strangei).

The above measurements indicate that the specimens from the Gulf of Siam (which are not full-grown) are more oblong-ovate in form. than is shown by the ligures which have hilherto been published.

\section{Tellina (Arcopagia) inflata, Chemn.}

Tellina inflala, Chemnir\%, Conchyl. Cabin., V1. 1782, p.91, pl. 9, tig. 76.

- - - Sibnglik, Skrivter af Naturl.. Selsk, IV, 2 11., 1798, 1. 99, No. 27 (non varr.).

1 Memoirs of the Liter, \& Plilos. Soc. Manchester, vol. 42, 1898, No. 4, p. 34.

2 The Fauna and Geography of the Maldive and Laceadive Archipelagoes, ed. by J. ST. GAmLER, 11, p. 627, 1903. Mecvili and Syris have already stated (in Proce of the Malacolog. Soc. London III, 1897, p. 47) that: "T. carnicolor Hanl. appears to be identical with $T$. corbis Sby. and T. Strangei Desh." 
Tellina (Tellinella) inflata, Chemnitz, Ed. Smitu, Proc. Zool. Soc. London, 1891, p. 426, No. 211.

- striatula, LAnanck, Hist. nat. d. anim. s. vert., V, 1818, p. 529, No. 33. - ¿d. 2, VI, p. 201, No. 33.

- - - Hanley, Soweriz, Thes. Conchyl., 1, p. 255, No. 61, pl. 61, fig. 175.

- - - - ReEve, Conchol. icon., vol. XVII, Tellina, Sp. 34.

Arcopagia - - Bertin, Révision d. Tellinidés, p. 320, No. 9.

Tellina hippopoidea, Jonas, Phulpr, Abbild. u. Beschreib. neuer od. wen. gek. Conchyl., I, p. 72 (8), Tellina, pl. 1, lig. 3 .

Kol Lan, 30 fathoms, mud $(1 / 2)$. Koh Kram, 30 fathoms (1). S. of Koh Chuen, 30 fathoms, shells (1/2). Cape Liant, 9 fathoms, shells $(1 / 2)$. N. of Kolı Kahdat, 4-5 fathoms, coarse sand (1). S. of Koh Kahdat, 8-- 10 fathoms, mud (1/8). Between Koh Kut and Koh Kahdat, 6-10 fathoms, shells (2/2). W. of Koh Kut, 15 fathoms, mud (2/2). S. of Koh Mak, 5-6 fathoms (2).

Long. $12-30 \mathrm{~mm}$.

Distribution: - Singapore (shallow water, Sv. Gad), Nicobars, Andamans, Ceylon, Aden, Red Sea, Suez, Zanzibar, Maritius. - Philippines, China, Celebes, Java, Port Curtis, New Caledonia.

Chemnrtz's original specimens of T. inflata (in the Zoological Museum of the University of Copenhagen) are very large and rather thick-valved, ${ }^{1}$ but they exactly agree with ReEve's figure of $T$. striatula, Lam., and with the specimens from the Gulf of Siam. V.BERTIN, who has had an opportunity of consulting LAMARCK's original specimens of striatula, in his "Révision" gives both ReEve's and Hanley's (Sowerby) striatula as synonyms of the present species, Römer (in Martini u. Chemnitz, Conchyl. Cabin.) is mistaken with regard to his inflata, Ch., neither his description nor his figures agree with Chemnitz's species; ${ }^{2}$ Bertin also says that Römen is wrong in reporting striatula, Lam., to be young specimens of the West Indian T. fausta, Pult. The specimens from the Gulf of Siam, all of which are rather small and consequently thin-valved, entirely agree with ReEve's figure of striatula. It appears as if the convexity of the valves varies somewhat in this species; thus, in a specimen from the Gulf of Siam, measuring $25 \mathrm{~mm}$. in breadth and $21 \mathrm{~mm}$. in height, the thickness is $10.5 \mathrm{~mm}$., while in an individual from Suez, ${ }^{3}$ of the same breadth and height, it is only $7 \mathrm{~mm}$.

Tellina languida, Edg. Smith, is very closely related to the present species.

Tellina (Arcopagia) pinguis, Hanl.

Tellina pinguis, HAxLFY, Proc. Zool. Soc. London, XII, 1844, p. 63.

- - - Sowerry, Thesaur. Conchyl., I, 13. 252, No. 55, pl. 56, fig. 34.

- - - ReEve, Conchol, icon., XVII, Tellina, Sp. 172.

- Arcopagia) pinguis, Hanley, Römer in Martini u. Chemnitz, Conchyl. Cabin., X IBd., 4 Abth., p. 96. Arcopagiu pinguis, HanleY, V. BERTiN, Révision d. Tellinidés, p. 322, No. 15

I Chemnitz's figure is not good and is partially misleading.

" RöMER is hard to be understood, when his figure of inflata (pl. 15, figs. 1-3) is compared witl the figure of striatula by HaNLeY (pl. 61, fig. 175), which he gives as a synonym; the two figures do not resemble each other in the least.

${ }^{3}$ In the Zoological Museum of the University of Copenhagen, received from L. VAILANT, who has determined it as T.truncata, HanI. (Journ. de Conchyl., 1865, p. 121, No. 79). 
N. of Koh Kam, 5 fathoms, gravel (1). Off Koh Kam, 10 fathoms, gravel (1). Koh Kahdat, 1 fathom, sand (1).

Long. 11-13.5 mm.

Distribution:- Philippines, Torres Strail, New Guinea (Brazıen), New Caledonia, Viti Isls.

The specimens are covered with a thin epidermis which is ornamented with concentric elevations separated by fairly regular intermediate spaces (about $0.5-1 \mathrm{~mm}$.) ; these elevations show most distinctly towards the ventral side, as the greater part of them is worn off upon the umbones, where they have left only concentric lines, which are, however, distinctly visible. Upon two of the specimens several red rays may be seen; and one of these two agrees almost completely with I. Adaus' Tellina Isseli from the Red Sea (Proc. Zool. Soc. London, 1870, p. 790, p1. 48, fig. 10). A. H. Cooke and Sturany consider 'T. Savignyi, Ad. (from the Red Sea), to be identical with $T$.pinguis, Hanl.; this I can scarcely believe, but as I have only, descriptions and figures to judge from, I cannot make any conclusive statement regarding this point; but it appears to me that T. balaustina L. (and T. Isseli, H. Ad.) are much more closely related to 'T.pinguis. It is almost impossible to distinguish between specimens of balaustina (from Algiers) and of pinguis from the Gulf of Siam.

Tellina (Arcopagia) Isseli, H. Ad.

Tellina (Arcopagia) Isseli, H. AbaMs, Proc. Zool. Soc. London, 1870, p. 790, pl. 48, fig. 10, Arcopagia Isseli, H. Adans, V. Bertax, Révision d. Tellinidẻs, 1). 324, No. 26.

Tellina - - Evg. Smin, Proc. Zool. Soc. London, 1891, p. 395, No. 15.

- (Arcopagia) Isseli, H. Adams, Melvill and Standen, Proc. Zool. Soc. London, 1406, p. 821.

Koh Kahdat, 1 fathom, sand (1).

Long. $9 \mathrm{~mm}$.

Distribution:- Bombay (Melvil,, Brit. Mus.), Mekran coast, Gulf of Oman, Persian Gulf (Melvill \& Standen), Aden, Red Sea, Gulf of Suez.

When EDG. SMTr in 1891 published "On a Collection of Marine Shelis from Aden" 1 he said regarding this species: "I am not aware that it has been found anywhere except in the Gulf of Suez." But, as may be seen from the above list of distribution, it has since been recorded as occurring considerably farther towards the east.

\section{Tellina (Arcopagia?) nux, Hanl.}

Tellina mix, HaNLey, Proc. Zool. Soc. London, XII, 1844, p. 62.

- - - Sowenв , Thesaurus Conchyl., I, p. 251, No. 54, pl. 56, fig. 33.

- - - ReEve, Conchol. icon., XVII, Tellina, Sp. 76.

- Nux, - Römen in Martivi u. Chensitz, Conchyl. Cabin., X 13d., 4 Abth., p. 88, No. 53. Arcopagia nux, Hanley, V. Bentin, lévision d. Tellinidés, p. 321 , No. 10.

Tellina - _. DunkEn, Index molluscor. mar. Japon., 1882, p. 191.

Arcopagia Nax, - Husrgo, Obras malacológicas, 1, tom. 11, 1903, p. 151, No. 26.6. 
Sound of Koh Chang, 5 fathoms, soft clay (1/2). Koh Mak, sandy coast (1/3). Between Koh Chuen and Koh Chang, 15 fathoms, mud (2). Between Koh Kul and Koh Kahdat, 10 fathoms, shells $(1 / 2)$. W. of Koh Kut, 30 fathoms, sand and mud $(2 / 2)$. Long. 6.5-13 mm. (long. $13 \mathrm{~mm}$., alt. $10 \mathrm{~mm}$.).

Distribution:- Karachi (Melvill \& Standen). - Philippines, Japan, Upolu (Mus. Godeffroy).

The figures in Röner's Monograph (pl. 24, figs. 1-3) bear no resemblance whatever to T.nux, Hanl.; they undoubtedly represent quite a different species.

\section{Tellina (Arcopagia?) casta, Hanl.}

Tellina casta, HANLEy, Proc. Zool. Soc. London, X11, 1844, p.63.

- - - Sowerny, Thesaur. Conchyl., I, p. 253, No. 57, pl. 56, fig. 9.

- - - ReEve, Conchol. icon., XVII, Tellina, Sp. 269.

- (Arcopagia) casta, Haxley, Römer in Mantixi u. Chemsitz, Conchyl. Cabin., X Bd., 4 Abth., p. 95. Arcopagia casta, Haxlfy, V. Bentix, leévision d. Tellinidés, p. 323, No. 21.

Tellina (?) casta, - EDG. SMrt, Lamellibranchiata of the Challenger Exped., p. 109.

E. of Koh Chuen, 9-10 fathoms, shells (1). Gulf of Rayong, 7-10 fathoms, sand and mud $(3+1 / 2)$. S. of Koh Samit, 20 fathoms, mud (1). Koh Kahdat, 1-10 fathoms, mud, sand and clay $(5+26 / 2)$. W. of Koh Kut, 15 fathoms, mud (2).

Long. 5-16 $\mathrm{mm}$.

Distribution:- Singapore (HanleY; Danish Exp. to Siam, 2-3 falloms, coral-reef (5); Sv. GAD, shallow water), Mergui Archipel. — Torres Strait, Tonga Isls., Upolu (Mus. Godefiroy).

The present species is easily distinguishable from forms allied to it, by the left valve being more convex than the right; it is always quite white in colour. The specimens from the Gulf of Siam are more oblong than the figures given by REEvE and Soweris; the height of an individual, $13 \mathrm{~mm}$. long, is $10 \mathrm{~mm}$.

\section{Tellina (Arcopagia?) declivis, Sow.}

Tellina declivis, Sowerny, ReEve, Conchol. icon., vol. 17, 1868, Tellina, Sp. 261.

Arcopagia declivis, Sowrary, V. Bertin, Révision d. Tellinidés, p. 324, No. 25.

W. of Koh Chang, 30 fathoms $(1 / 2)$. Koh Kahdat, at the strand $(3 / 2)$. Between Koh Kut and Koh Kahdat, 10 fathoms, shells (2/2). W. of Kut, 15 fathons, mud (1/3).

Long. 5-10 $\mathrm{mm}$. (long. $10 \mathrm{~mm}$., alt. $8.5 \mathrm{~mm}$.).

Distribution unknown. (Singapore, 2-3 fathoms, coral-reef (1 right valve), Danish Exp. to Siam).

My specimens exactly agree with Sowerby's description and figure; they are easily distinguished from $T$. pudica, to which species they are most closely allied, by the greater convexity, and by the predominance of the height of the valves in comparison with their length. 


\section{Tellina (Arcopagia?) languida, Sm.}

Tellina(9) languida, EDg. Smтн, Report on the Lamellibranchiata of the Cliallenger Expedition, 1885, p. 110, pl. 4 , fig. 8.

Between Koh Rin and Cliff Rock, 15 fathoms (1/2). Koh Kram, 30 fathoms (3). Koh Chuen, 30 fathoms (1/2). Gulf of Rayong, $7-10$ fathoms, sand and mud (1/2). S. of Koh Samit, 20 fathoms, mud (1). Sound of Koh Chang, 3 lathoms, soft clay (1/s). Around Koh Kahdat, 1-10 fathoms, sand, mud, clay, and shells $(5+11 / 2)$. W. of Koh Kut, 15-30 fathoms, mud $(2+3 / 2)$.

Long. 6-11 mm. (long. $11 \mathrm{~mm}$., alt. $9 \mathrm{~mm}$., crass. $5 \mathrm{~mm}$.).

Distribution: - Torres Strait and Flinders Passage (Cindlenger).

The species T. nux, casta, robusta, declivis, languida, pudica, etc., form a natural chain or group, which, on the one hand, cannot be placed entirely in LEACr's subgenus Arcopagia, ( $\mathrm{H}$, and A. Apams have done this, notwithstanding the fact that the character "posterior side rounded" is wanting in several of the species), but, on the other hand, it shows how much the division into subgenera of the genus Tellina needs critical investigation. Several authors (e. g. Récruz ${ }^{1}$ and Röser ${ }^{2}$ ) have already attached but little importance to this subgenus Arcopagia.

\section{Tellina (Arcopagia?) pudica, Hanl.}

(P. III, Figs. $35-37$ ).

Tellina pudica, Hanles, Proc. Zool. Soc. London, XII, 1844, p. 62.

- - - Sowerny, Thesaurus Conchyl, I, p. 246, No. 46, pl. 56, fig. 7.

- - - ReEve, Conchol. icon., XVII, Tellina, Sp. 176.

(Arcopagia) pudica, Haxley, Röner in Maftivi u. Chemsitz, Conchyl. Cabin., X Bd., 4 Abth., 1). 95.

(Peroncea) -- - - V. Bertin, Révision d. Tellinidés, p. 272, No. 103.

A great many specimens taken from numerous localities between Koh Chuen and Koh Kong, 3-30 fathoms, mud, clay.

Long. 3-9.5 $\mathrm{mm}$.

Distribution:- Philippines, Japan (Allart).

The specimens from the Gulf of Siam have a somewhat longer rostrum than that shown in the figures by HANLEY and REEvE; this species is characterised by being strongly polished, glossy, smooth and milk-white in colour; the umbones are prominent and rounded at their apices, and the whole outline recalls that of a Nuculana or (as Handex says) of a Neaera.

\section{Tellina (Arcopagia?) Smithi n. sp.}

(Pl. III, Figs, $38-39$ )

This sliell is ovately-triangular in form, very thick-valved, pure white in colour, and somewhat glossy. The anterior end, which is roundly elongated, passes evenly into the ventral side, the latter is slightly curving and passes without angle-forma-

1 Hevue zoologique publ. p. Guc̉rin-Méncville, 1846, pp. 48-55.

2 Maktrini u. Chemnitz, Concliyl. Cabib. X Bd., 4 Abth., p. 72. 
tion into the somewhat truncated posterior side. The umbo is situated towards the posterior side and the apex bends towards it. The umbo is fairly high and slopes gradually downwards on both sides. The surface is coyered with close-set, regularly-arranged, concentric strix; some of these terminate at the place on the posterior side where they bend upwards, and only every other is continued upwards to the area which is limited by a small keel. The interior of the valve is pure white; in the right valve (which alone is at hand) the lateral teeth are strongly developed on each side; there are two cardinal teeth, of which the hinder is the larger. The pallial sinus is large and deep, but appears very indistinctly upon the glossy inner surface.

Long. $5.5 \mathrm{~mm}$., alt. $5 \mathrm{~mm}$, crass. $3 \mathrm{~mm}$.

West of Koh Kut, 30 fathoms, sand, mud.

As the left valve is not known I cannot decide with certainty whether this species belongs to the subgenus Arcopagia.

I have ventured to associate with the name of the present species that of Mr. EDG. SMrt, to whom malacological science is indebted for so many valuable works.

\section{Tellina (Merisca) Martensi n. sp.}

(PI. II, Figs. 40-42).

This shell is small, white, rather thick-valved and triangular in outline. The surface is ornamented with more or less close-set, raised, concentric lamella, the interspaces are smooth and somewhat glossy. The umbones, which are situated at about the middle of the shell, are pointed and prominent, and slope rather abruptly downwards on both sides. The somewhat swollen anterior end passes gradually, and with rounded outline, into the ventral side which is convex and forms a rather acute angle with the hinder side. 'The posterior part exhibits a slight "Tellinacurvature." "The interior of the valves is white and glossy. In the right valve there are two cardinal teeth, and two oblong, strongly developed lateral teeth; in the left valve there are no lateral teeth and of the two cardinal teeth the anterior is the larger. The pallial sinus is large and deep.

South of Koh Kut, 17-20 fathoms, mull (1/2). (Singapore, 2-3 fathoms, coralreef; $5 / 2)$.

Long. $3.5 \mathrm{~mm}$., alt. $3 \mathrm{~mm}$., crass. $2 \mathrm{~mm}$.

This little characteristic Tellina-form must be referred to DALL's section Merisca of the subgenus Arcopagia; it somewhat resembles the much larger T. (Merisca) crystallina, Wood, ${ }^{1}$ from South Carolina, but that species is longer, and has a more decided rostrum. The specimens at hand show that the species varies considerably in regard to form and the density and height of the lamellae. I have named this species after the late Professor ED. V. MARTEns, the first zoologist who gave us a fauna of the Mollusca of Siam, and to whom malacological science is indehted for many profound and valuable papers and works.

\footnotetext{
1 Proceed. Unit. Stat. Nat. Mus., vol. 23, 1900, p. 311, pl. 2, fig. 10.
} 


\section{Tellina (Quadrans) gargadia L.}

Tellina Gargadia, Linné, Syst. Nat., ed. X, 1758, p. 674, No. 33. - ed. XII, p. 1116, No. 4t. - Mus. Ludov. Ulr., 1764, p. 476 , No. 19.

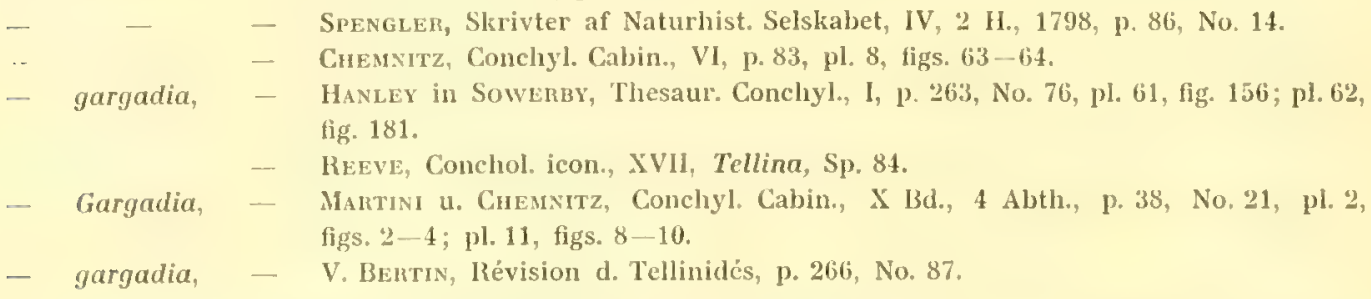

N. of Koh Kahdat, 4-5 fathoms, coarse sand $(1 / 2)$. Koh Kahdat, 1 fathom, sand $(3 / 2)$. Between Koh Riot and Koh Mesan, 3-5 fathoms, sand (1/2).

Long. $10-30 \mathrm{~mm}$.

1) long. $30 \mathrm{~mm}$., alt. $22 \cdot 5 \mathrm{~mm}$.

2) - $25 \mathrm{~mm} .,-18.5 \mathrm{~mm}$.

Distribution:- Nicobars, Ceylon, Seychelles, Zanzibar. - Philippines, Batjan, Mast Head Reef (Queensland), New Caledonia, Pelew Isls.

This species varies considerably both in form and in sculpture. "The specimens from the Gulf of Siam are all rather small, with slightly prominent sculpture and, as the above measurements show, of ovately-oblong form; they come nearest to HAxtey's T. inaequalis, but judging from the figures and descriptions I camnot see that that species is anything but a form of gargadia, to which species I have therefore referred my specimens. HiDALGO ${ }^{1}$ arrived at the same conclusion, when treating the specinens from the I'hilippines; he regards $T$. innequalis, Hanl, to be synonymous with 'T. yargadia L.

\section{Tellina (Quadrans) minor, V. Bertin.}

Tellina minor, V. Bentr, Révision d. Tellinidés, 1878, p. 267, No. 90, pl. 9, fig. 5.

Belween Koln Riot and Koh Mesan, 5 fathoms, sand (3/2). Between Koh Mesan and Cape Liant, 5-9 fathoms (1/2). Koh Kahdat, 1 fathom, sand (1). W. of Koh Kul, 15 fathoms, mud $(1 / 2)$.

Long. 5-9 $\mathrm{mm}$. (long. $9 \mathrm{~mm}$., alt. $6.5 \mathrm{~mm}$., crass. $3.5 \mathrm{~mm}$.).

Distribution:- New Caledonia (Bertin).

\section{Tellina (Tellinides) carinata, Spengl.}

Tellina tenuis ovalis, Chemsirz, Conclyyl. Cabin., VI, 1782, p. 97, pl, 10, tig. 87.

carinala, Splenglin, Skrivter af Naturhistorie-Selskabet, IV, \& H., 1798, p. 110.

- ablonga, Gimein, Linné, Syst. Nat., cd. Xill, 1790, p. 3234, No 29.

Tellinides cmarginatus, Sowlany, A Catalogue of the Shells in the Collection of the Larl of lankerville, 1825, Appendix, p. 111, No. 199.

Tellina (Tellinides) emarginata, Sowenis, Hanury, Monogx, of the gen. Tellina. (Sowenus, Thes. Conchyl., I) p. 290, No. 130, pl. 57 , fig. 70 .

1 J. G. Hidalgo, Obras malacológicas, I, Tom. II, 1903, p. 122. 
Tellina emarginata, Sowerny, Reves, Conchol. icon., XVII, Tellina, Sp. 99.

- (Tellinides) emarginata, Sowerby, Rönen in Martini u. Chesnitz, Conchyl. Cabin., $\mathbb{X}$ Bd, 4 Abth.

p. 177 , No. 105 , pl. 36 , figs. $1-3$.

- (Homala $)$ - _ - V. Bertin, Révision d. Tellinidés, p. 291, No. 182.

Between Koh Rin and Cliff Rock, 15 fathoms (3). Gulf of Rayong, 7-10 fathoms, sand and mud (1/2). S. of Koh Chuen, 30 fathoms, shells (1). Koh Kahdat, 10 fathoms (several quite young individuals).

Long. $7-27 \mathrm{~mm}$.

Distribution: - Singapore, Mergui Archip., Bombay, - Torres Strait.

As Spengler's original specimens of T. carinata are in the Zoological Museum of the University of Copenhagen, it has been possible for me to verify the fact that Sowerby's species emarginata is synonymous with the present species. Soweriy's specific name must therefore give place to that given by SPENGLER, which has the priority. GMELIN's name oblonga (from 1790) has not the priority, because Chemnit', in 1782, mentions Spenglers's manuscript-name carinata, which SPENGLER himself afterwards published. 'The native land of the species has been very erroneously recorded; Spengler records the coast of Guinea, Chemnitz and Salis Marschlins ${ }^{1}$ the European Seas, and Sowerby Brazil, all of which localities are undoubtedly wrong.

Tellina (Tellinides) psammotella, Lam.

Tellina psammotella, LAMABck, Hist. nat. d. anim. sans vertèbres, V, 1818, p. 528, No. 30. - éd. 2, VI, 1835 , p. 199 , No. 30 .

- I'sammotella, - Hanler, Descript. Catal. of recent biv, shells, p. 65, pl. 14, lig. 6.

- - HaneeY in Sowenby, Thesaur. Conchyl., I, p. 290, No. 129, pl. 60, fig. 134.

- _ _ Reve, Conchol. icon., XVII, Tellina, Sp. 71.

- (Tellinides) Psammolella, Lamarck, Römen in Mantini u. Chemnitz, Conchyl. Cabin., X Bd., 4 Abth. p. 176 , No. 104 , pl. 35 , figs. $12-14$.

Macoma psammotella, Lamanck, V. Bentin, Révision d. Tellinidés, p. 337, No. 11. "

- Psammotella, - Hudago, Estud. prelim. sobre la fauma malacol. de las Islas Filipinas, I, 1903, p. 160 , No. 280 .

Sound of Koh Chang, 5 fathoms, soft clay $(6 / 2)$.

Long. 11-16 mm. (long. $16 \mathrm{~mm}$., alt. $9 \mathrm{~mm}$.).

Distribution:- Singapore, shallow water (Danish Exp. to Siam, and Sv. Gav). Cebu (Philippines, Quadras).

LAMARCK states that the interior of his specimens are ornamented with orange, red, or purple rays, but this is not the case with the individuals which I have before me, all of which are interiorly (and exteriorly) uniform in colour, pale-red (llesh-coloured). As regards the lateral teeth, Hanley (Thesaur. Conchyl.) olserves, "lateral tooth distinct, approximated," while REEve, in his diagnosis, says, "lentihus lateralibus nullis." V. Bertin and Hidalgo, on the basis of the latter statement, without investigating the subject more closely, have referred the species to Macoma.

1 Reisen in versch. Provinzen d. Königr. Neapel, I, 1793, p. 384, No. 108. 
In reality the lateral tecth (and the hinge as a whole) are developed as in Tellina emarginata, Sow, to which species also, $T$. psammotella comes nearest in external appearance.

Tellina (Tellinides) vestalis, Hanl.

Tellina vestalis, HaNrey, l'roc. Zool. Soc. London, XI, 1844, p. 141.

Monograph of the gen. Tellina (Sowerisy, Thesaur. Conchyl., I), 1. 291, No. 132, pl. 57, fig. 67.

- $\quad$ - $\quad$ Reve, Conchol. icon., XVII, Tellina, Sp. 230.

- (Tellinides) vestalis, Hanley, hömen in Martini u. Chemsitz, Conchyl. Cabin., X I3d., 4 Abth., p. 174, No. 103 , pl. 35 , figs. $9-11$.

S. of Koh Kahdat, 8-10 fathoms, mud (1). Between Koh Kahdat and Koh Kiut, 6 fathoms, clay mixed with sand $\left(1^{1 / 2}\right)$. W. of Koh Kut, 15 fathoms, mud. $(1 / 2)$. Long. 9-28 $\mathrm{mm}$.

Distribution:- Karachi (Melvill \& Standen), Mauritius. - Philippines.

I very much doubt whether Römen (loc. cit.) had the true T. vestalis, Hanl. before him; neither his figure nor his description agrees with HAxLEY's species.

\section{Tellina (Tellinides) ovalis, Sow.}

Tellinides ovalis, G. 13. Soweruy, Catalogue of the Shells in the Collect. of the Earl of Tankerville, 1825 , Append., p. 11I, No. 198.

HANLEY, Catal. of rec. biv. shells, p. 73 , pl. 13 , fig. 56.

Tellina (Tellinides) ovalis, Sowerix, Hander, Thesaur, Conchyl, I, p. 296, No. 142, pl.60, fig. 147.

- ovalis, Sowribri, Rerve, Conchol. icon., XVII, Tellina, Sp. 105.

- - - Lischie, Japan. Meeres-Conchyl., III, p. 94.

- - - Bertin, Révision d. Tellinidés, 1878, p. 284, No. 140.

- ․ - Dunker, Index moll. mar. Japon., 1882, p. 190.

-- - - Hidalgo, Moluse. mar. de las Isl. Filipinas, 1903, p. 134 , No. 238.

Solen ex albido radialus, Chemsixz, Conchyl. Cabin., VI, 1782, p. 71, pl. 7, figs. 57 - 58.

- strialus, Guelin, Syst. Nat., ed. XIII, p.3227, No. 19.

Tellina tridentata, ANTOs, Archiv f. Naturg., III, 1837, I3d. I, p. 283.

- gratiosa, Römer in Mantinı u. Chemnitz, Conchyl. Cabin., X 13d., 4 Abth., p. 170, No. 100, pl. 34 figs. $10-12$.

OIf Koh Kam, 10 fathoms, gravel $(1 / 2)$.

Long. $37 \mathrm{~mm}$., alt. $23.5 \mathrm{~mm}$.

Distribution: - Nicobars, Karachi, Persian Gulf, Gull of Suez, Red Sea (Cossil, V. Bertin), Madagasear.-- Philippines, Moluccas, Japan.

\section{Tellina (Moerella) semen, Hanl.}

Tellina semen, Haxley, Proc, Zool. Soc. London, XII, 1844, p. 164.

Sowlin;, Thesaur. Conchyl., I, p. 249, No. 51, pl.56, fig. 8.

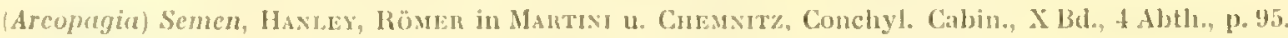
(IIomala) semen, - V. BERTiN, Révision d. I’ellinidés, p. 303, No. 268.

semen, Haxher, Eug. Smitr, Report on the Zool. Collections made in the Indo-Pacitic Ocean during the voyage of "Alert," 1881, p. 99.

(?) semen, HaNiEY, EDG. Swru, Rep. on the Lamellibranchiata of the Challenger Exped., p. 111. (Moera) semen, Hanify, Melvill \& Standen, Proc. Zool. Soc. Lundon, 1906, p. 821. 
Off Koh Kam, 10 fathoms, gravel (1/2). Between Kol Mesan and Cape Liant, 5-9 fathoms (1/2). Between Koh Kut and Koh Kahdat, 10 fathoms, shells ( $\left.{ }^{2} / 3\right)$.

Long. 6-9 mm. (long. $9 \mathrm{~mm}$., alt. $7 \mathrm{~mm}$.).

Distribution:-- Karachi, Mekran coast, Persian Gulf, Durban. ${ }^{1}$ - Philippines, Torres Strait, Flinders Passage, Viti Isls.

Sowerby's figure in ReEve's "Conchol. icon." (pl.41, sp. 232), which EDG. Smiti regards as "bad," agrees fairly well with the individuals from the Gulf of Siam, and although it is not perfectly typical, yet it can be recognised; besides, it agrees well with Sowerby's original figure in "'Thesaurus Conchyliorum."

\section{Tellina (Moerella) semitorta, Sow.}

(Pl. III, Figs. 43-46).

Tellina semilorta, Sowenby, Rerve, Conchol. icon. XVII, 1867, Tellina, Sp. 221.

- (Mor $\alpha$ ) semitorta, Sowerby, Angas, P'roc, Zool. Soc. London, 1867, p. 919.

- (?) - - - Evg. SMrt, Report on the Lamellibranchiata of the Challenger Exped., p. 111.

- Donacilla) semitorta, Sowenbr, Melvil. \& Standex, Journ. Linn. Soc. Zool., XXVII, p. 201.

- _.. _ _ V. BERTin, Révision d. Tellinidés, p. 263, No. 81.

Between Koh Rin and Cliff Rock, 15 fathoms ( $\left.{ }^{2} / 2\right)$. Koh Kíram, 30 fathoms ( $/ 2$ ). N. of Koh Kam, 5 fathoms, gravel $(4+3 / 2)$. Off Koh Kam, 10 fathoms, gravel (1/2). Between Koh Mesan and Cape Liant, 5-9 fathoms (12). North side of Koh Mesan, 10-15 fathoms, stones $(3 / 2)$. Gulf of Rayong, $7-10$ fathoms, sand and mud $\left(1+{ }^{1} / z\right)$. Between Koh Kut and Koh Kahdat, 10 fathoms, shells ( $1 / 2$ ). W. of Koh Kut, 15-30 fathoms, mud $(1+2 / 2)$. Koh Kahdat, $1-5$ fathoms, sand $(2+9 / 2)$.

Long. 25-12 $\mathrm{mm}$.

Distribution:- Singapore (low water, Sv, GaD). Torres Strait, Port Jackson (Sydney), Watson's Bay (New South Wales).

This species varies considerably in form; on Pl. III, Figs. 43-46, I have given several instances of this; " the sculpture, also, is very variable. Thus, for instance, the concentric striation may be more or less close-set; and the place where the less close-set, posterior striation meets the rest of the valve-sculpture is often situated very far back, while in other specimens it may be at about the middle of the valve; and often the more prominent lamellar sculpture upon the posterior end has almost entirely disappeared, and the sculpture is nearly uniform over the whole surface of the valve. Nor is the striation, as a rule, the same on both valves. The tortuosity of the posterior end of the valves, mentioned by Eog. SMrn (loc. cit., p. 112), is in one specimen directed towards the right, and in another towards the lelt. Smin's statement that: "the anterior lateral teeth and the plate supporting the ligament are tinged with pale-red," is not found in the specimens from the Gulf

1 Edg. Suitr, Proc. Malacolog. Soc. London, vol. 5, p. 400.

2 Evg. SMtu's criticism of Sowerbr's figure in ReEve's "Conchol. icon." is unjustified; several specimens from the Gulf of Siam have the form shown in Sownm figure. 
of Siam; only in one individual is there any indication of this tinge of colour; in that specimen the red colour radiates downwards over the valves, both within and without, but in all the others the shells are quite white, with a thin yellow epidermis, which is often quite worn off, or is present only in remmants.

\section{Tellina (Moerella) Berghi n. sp.}

(PI. III, Figs. $47-49)$.

This shell is oblong-ovate, white and rather thick-valved; the umbones are siluated towards the posterior end; a slight indication of a keel extends from the umbo obliquely down towards the posterior angle of the ventral side, which curves gently like the anterior and posterior sides, into which it passes without angleformation. The surface is sculptured with close-set, parallel, raised, concentric striae; on the posterior side some of these strix, for want of space, do not extend guite to the hinder upper margin, but otherwise all the strice extend entirely round the valve. These raised concentric strix, and also the spaces between them, are ornamented, with very fine, close-set, concentric lines, which are again crossed by fine radiating grooves which become more distinct the nearer they approach the rentral side; all of which produces, if seen under the lens, an exceedingly beautiful and fine beadlike sculpture, resembling fine weaving. "The interior of the valves is white and glossy. In the right valve there are two well developed, oblong lateral teeth and two cardinal teeth, of which the hinder is bifid and considerably larger than the anterior.

Long. $7 \mathrm{~mm}$., alt. $5 \mathrm{~mm}$, crass. $3 \mathrm{~mm}$.

The strand of Koh Kahdat $(1 / 2)$.

This species belongs to the group T. semen, Hanl., T. semitorta, Sowb., T. miracyllum, Melv., ete., but its characteristic and beatilul scupture casily distinguishes it from nearly-allied species. Unfortunately only one right valve was obtained. I have dedicated this species to the late Professor RUD. BERGH, the eminent author of so many valuable works on Mollusca, who has also described the Nudibranchs of the Gulf of Siam, and to whom I personally owe thanks for much encouragement and kindness.

\section{Tellina (Moerella) tenuilirata, Sow.}

Tellina tenuilirala, Sowenby, Rerve, Conchol. icon., XVII, 1867, Tellina, Sp), 219 (non T. tenuilirala, Sowerby, Conchol. icon., Sp. $253=$ T. semilaevis, v. Martens).

- Angas, Proc. Zool. Soc. London, 1867, p. 919, No. 48.

- Edg. Smith, Rep. Lamellibranchiata of the Cliallenger Exped., p. 106.

(IJomala) lenuilirata, Sowenny, V. Bentin, Rëvision d. Tellinidés, p. 299, No. 234.

tenuilirala, Sowemis, Pmtchalid \& Gatrifi, Proceed. Hoy. Soc. Victoria, XVI, 1903, p. 116.

Koh Kram, 30 fathoms (3/2). Between Koh Mesan and Cape Liant, 5-9 fathoms, sand $(1 / 2)$. N. of Kioh Kam, 5 fathoms, gravel (1/2). Ofr Koh Kram, 10 fathoms, gravel (1/2). Gulf of Rayong, 7-10 fathoms, sand, mud (1). Koh Kahdat, 1-5 fathoms, sand $(2 / 2)$. 
Long. 4-11 $\mathrm{mm}$.

Distribution:- Flinders Passage (Torres Str.); Port Kembla and off Cape Three Points (New South Wales, HedLey); Port Jackson, Sydney; Frankston, Port Philip (Victoria); Levuka, Viti Isls.

\section{Tellina (Moerella) obtusalis, Desh.}

Tellina obtusalis, Deshayes, Proc. Zool. Soc. London, 1854, p. 355, No. 176.

$-\quad-\quad-\quad$ ReEve, Conchol. icon., XVII, 1868, Tellina, Sp. 281.
- EDg. SMith in: Report Zool. Collect. made during the Voyage of H. M. S.
"Alert," 1884, p.99.

- Homala) obtusalis, Deshayes, V. Bertin, Révision d. Tellinidés, p. 298, No. 231.

- Malaccana, Sowerby, Reeve, Conchol. icon., XVII, 1867, Tellina, Sp. 125.

- (Donacilla Malaccana, Sowerby, V. Bertik, Révision d. Tellinidés, p. 262, No. 80.

Koh Kahdat, on the strand ( $/ 2)$. Between Koh Kut and Koh Kahdat, 10 fathoms, shells $(1 / 2)$.

Long. $7 \cdot 5-10 \mathrm{~mm}$.

Distribution: - Malacea, Karachi (Melvil \& Standen). - Viti Isls. (Brit. Mus.).

As the specimens are in a bad state of preservation the determination is somewhat uncertain.

Note. Tellina (Moerella) compacta, Edg. Smith, has been taken by Sv. Gad (a single left valve, worn) at Singapore, in shallow water.

\section{Tellina (Angulus) lux, Hanl.}

Tellina lux, HANLey, Proc. Zool. Soc. London, XII, 1814, p. 140.

- - - Sowerby, Thesaur. Conchyl., I, p. 288, No. 126, pl. 57, fig. 71.

- - - Reeve, Conchol, icon., vol. XVII, Tellina, Sp. 286.

- (Angulus) Lux, Hanley, Römer in Maktini u. Chemnitz, Conchyl. Cabin., X 13d., 4 Abth., p. 159.

- - lux, - EDg. Sмттн, Report on the Lamellibranchiata of the Challenger Exped.,

p. 102.

- (Homala $-\quad$ - V. Bertin, Révision d. Tellinidés, p. 296, No. 217.

W. of Koh Kut, 30 fathoms, sand and mud $(1+2 / 2)$.

Long. 14-16 mm., alt. 9-10 $\mathrm{mm}$.

Distribution:- Persian Gulf, Gulf of Suez (MaC Andrew). - Philippines, Torres Strait, Arafura Sea.

The specimens from the Gulf of Siam are pale-red in colour.

Tellina (Angulus) corbuloides, Hanl.

Tellina Corbuloides, Hander, Proc. Zool. Soc. London, XII, 1844, p. 70.

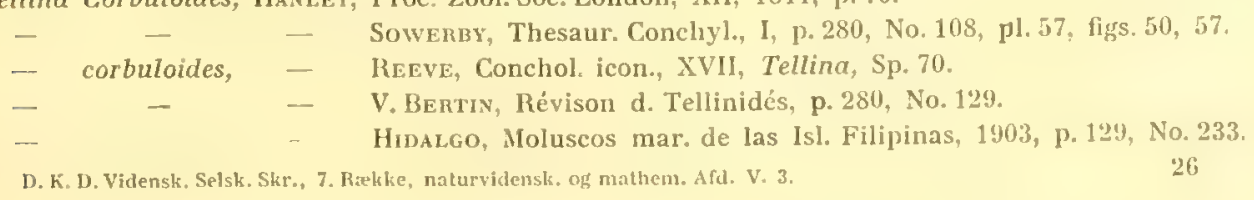


The coast of Lem Ngob (1).

Long. $135 \mathrm{~mm}$.

Distribution:- Philippines, Borneo.

The form which Römer figures and describes (Mantini u. Chemnitz, Conchyl. Cabin., X Bd., 4 Abth., p. 155, No.95, pl.33, figs. 8-10) under the name of 'T. corbuloides is not Hanley's species.

\section{Tellina (Angulus) iridescens, Bens.}

Sanguinolaria iridescens, W. H. Benson, Annals and Magaz. of Nat. Hist., vol. 9, 1842, p. 490.

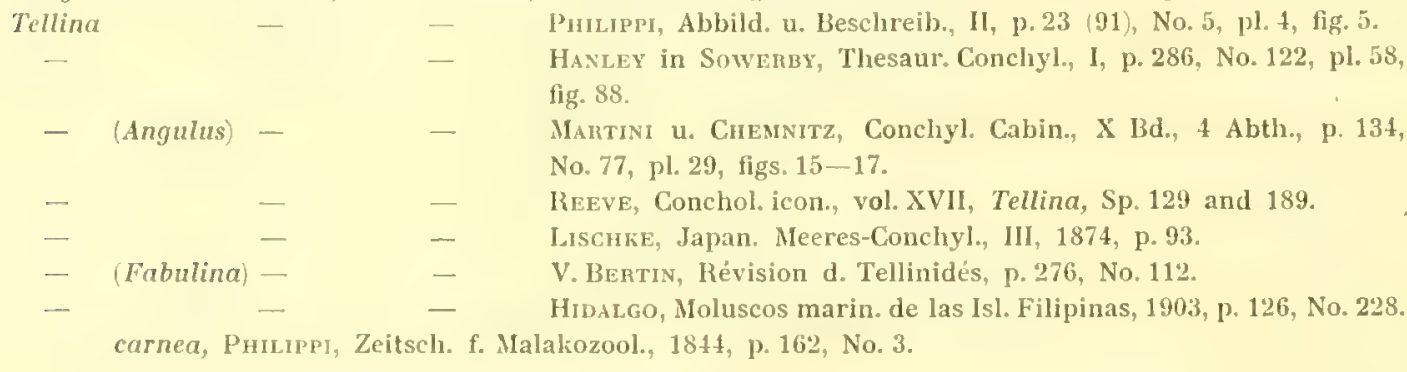

The sound of Koh Chang, 5 fathoms, soft clay $(3 / 2)$.

Long. $14-20 \mathrm{~mm}$. (long. $20 \mathrm{~mm}$., alt. $11.5 \mathrm{~mm}$.).

Distribution:- Karachi (Melvill \& Standen). - Philippines, China, South Japan, Torres Strait.

The individuals from Koh Chang exactly agree with some specimens in the Zoological Museum in Copenhagen from Chusan (forwarded by 'TH. Cantor). ReEve's figures give the characteristics of the species most accurately.

\section{Tellina (Angulus) iridella, Mart.}

Tellina iridella, E.v. Martens, Annals and Magaz. of Nat. Hist., 3 Ser., vol. XVI, 1865, p. 431, No. 9.

- (Macoma) iridella, E. v. Martens, Kömen in Martini u. Chemnitz, Conchyl. Cabin., X Bd., 4 Abth., p. 256, No. 160, pl. 49 , figs. $4-6$.

- iridella, E. v. Mantens, Lischke, Japan. Meeres-Conchyl., II, p. 11t, pl. 10, figs. 8-9.

Macoma - - V V. Bertis, Révision d. Tellinidés, p. 350, No. 55.

W. of Koh Kut, 15 fathoms, mud (1).

Long. $13 \mathrm{~mm}$, alt. $8 \mathrm{~mm}$., crass. $3.5 \mathrm{~mm}$.

Distribution:- Japan, Loo-Choo Isls.

My specimen, like that of Lischise, has in the right valve a lateral tooth in front of the cardinal teeth. The species must therefore be referred to the subgenus Angulus, and not to Macoma, as previous authors have done.

\section{Tellina (Angulus) unifasciata, Sow.}

Tellina unifasciata, Sowenry, Rervi, Conchol. icon., XVII, 1867, Tellina, Sp. 156.

(Angulus) unifasciata, Sowerby, Avgas, Proc. Zool. Soc. London, 1867, p. 919, No. 49.

- (Fabulina - - - - V. Bentin, Révision d. Tellinidés, p. 281, No. 130. 
W. of Koh Kut, 15 fathoms, mud $\left({ }^{1} / 2\right)$. Between Koh Kut and Koln Kahdat, 10 fathoms, shells $(1 / 2)$.

Long. 9-10 $\mathrm{mm}$.

Distribution: - Arabian Sea (Melvil \& Standen), Gulf of Suez (Cooke), Seychelles (Brit. Mus.). - Port Jackson (Angas).

The specimen from the collection of PETIT DE LA SAUSSAYE mentioned by V. BERTIN, which is recorded with doubt from Florida, should unquestionably be omitted from the literature.

\section{Tellina (Angulus) dispar, Conr.}

Tellina dispar, Conmad, Journ. Acad. Nat. Sc. Pliladelphia, VII, part 2, 1837, p. 259, No. 4.

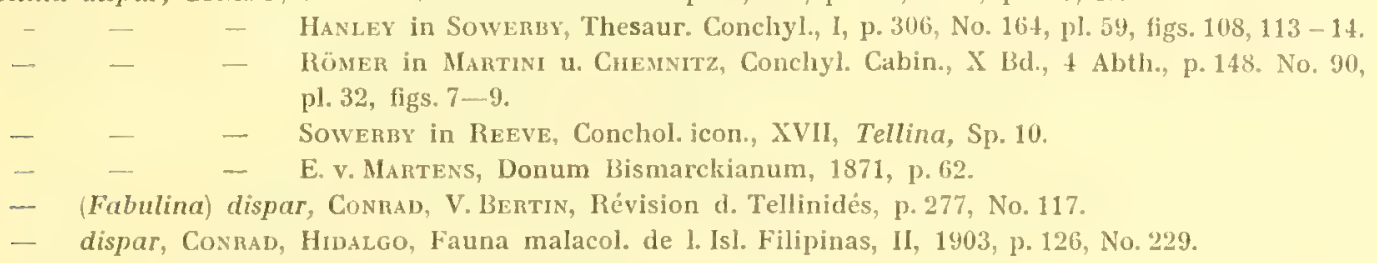

Koh Kahdat, 1 fathom, corals (1).

Long. $15 \mathrm{~mm}$.

Distribution:- Maldive Isls., Mauritius, Querimba IsIs. (Mozambique), Natal. - Philippines, Port Curtis and Moreton Bay (Queensland), Marianne Isls., New Caledonia, Lifu, Samoa Isls., Tahiti, Funafuti Atoll, Sandwich Isls.

The records of the occurrence of this species along the coast of California (Tryos and $\mathrm{JAY}_{A}$ ) and in the Strait of Magelhaens (BERTIY) are undoubtedly due to erroneous determination of allied species.

\section{Tellina (Angulus?) rhomboides, Quoy \& Gaim.}

Tellina rhomboides, Quoy et Gamand, Voyage de l'Astrolabe, Zoologie, II, 1833, p. 502, pl. 81, figs. $4-7$.

- Rhomboides, - Hanley in Sowenuy, Thesaur. Conchyl., 1, p. 304, No.162, pl. 58, figs. 92,96 and 97.

- rhomboides, - Rneve, Conchol. icon, XVII, Tellina, Sp. 114.

- (Angulus) rhomboides, Quor et Gamard, Römer in Martini u. Chemnitz, Conchyl. Cabin., X Bd.,

4Abth., p. 14, No. 87, pl. 31, figs. 14-17.

- (Fabulina $\quad$ - _ _ Bentin, Révision d. Tellinidés, p. 279, No. 123.

- (Angulus?) - _ _ Eog. Smith, Rep. on the Lamellibranchiata of the Clial-

lenger Exped., p. 103.

- clathrata, (Quoy) Deshayes, Lamanck, Hist. nat. d. anim. s. vert., 2 éd., 1835, VI, p. 208, No. 57. Hanler, Catal. of rec. biv. shells, p. 65, pl. 14, fig. 12.

- compta, Gould, Wirkes' Explor. Exped., vol. XII, p. 406, Atlas fig. 575. -- Otia Conchol., 1862, p. 79.

- lauta, - loc. cit., p. 408, Atlas fig. 514. - Otia Conchol., p. 79.

- silicula, Deshayes, Proc. Zool. Soc. London, XXII, 1854, p. 363, No. 209.

- - - - HeEve, Conchol. icon., XVII, Tellina, Sp. 278.

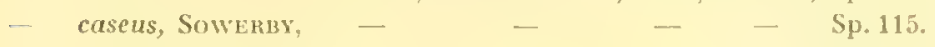

- texturata, - $\quad$ - $\quad$ - $\quad$ - $\quad-\quad$ pl. 41, Sp. 233; pl.45, fig. 233 b.

- reticulata, - $\quad$ - $\quad$ - $\quad$ - $\quad$ - $\quad$ - $\quad-\quad$ Sp. 252. 
Tellina (Peroncea) pura, H. Anams, Proc. Zool. Soc. London, 1870, p. 789, pl.48, fig. 6. - $\quad$ erythraensis, H. Apams, Proc. Zool. Soc. London, 1870 , p. 790, pl. 48 , fig. 8.
lactea, H.Apais, Proc. Zool. Soc. London, 1870, p. 790 (fide A. H. Cooke).

- subrosea, Römer (non Hanley), Mantini u. Chemnitz, Conchyl. Cabin., X Bd., 4 Abth., pl. 32 , figs. 14-16 (fide Hidalgo).

- bifaria, Baind, Brenchley's Cruise of the Curaçoa, 1873, p.451, pl.41, fig. 13.

Koh Kahdat, 1 fathom, sand (2). N. of Koh Kahdat, 4-5 fathoms, sand (1/2). S. of Koh Mak, 5-6 fathoms (1).

Long. 13-18 mm. (long. $18 \mathrm{~mm}$, alt. $10 \mathrm{~mm}$., crass. $55 \mathrm{~mm}$.).

Distribution:- Minilioi (Laccadive Archip.), Red Sea, Suez, Madagascar, Mauritius, Durban (Edg. Surn). - Philippines, Gulf of Jedo, Timor, Keeling Isls., New Guinea, Marianne Isls., New Hebrides, New Caledonia, New Zealand, Cape York (North Australia), Viti Isls., Funafuti (Ellice IsIs.), Lifu, Upolu, Paumotu Isls.

All the specimens from the Gulf of Siam agree most closely with HanLEy's figure (pl.58, fig. 96).

Note. When ED. v. MARTEns records (Malakozoolog. Blätter, vol. 21, 1873, J. 176) that Tellina (Scissula) virgo, Hanl., was taken "An Eingang des Golfs yon Siam, $8299^{\prime}$ Nordbreite, 16 Faden," it is cerlainly due to croneous determination. According to DAL. (Symopsis of the family Tellinidx, 1900, p. 304) the species occurs from "Gulf of California, Ja Paz, to Chiriqui." Also Haxley's original specimens are recorded from Chiriqui, West Columbia.

\section{Tellina (Peronaea) cygnus, Hanl.}

Tellina cygnus, Hanler, Proc. Zool. Soc. London, XII, 1844, p. 144.

$-\quad-\quad$ Sowerby, Thesaur. Conchyl., I, p. 310, No. 175, pl. 59, fig. 122.
$-\quad-\quad$ Peroncal) cygnus, Hanley, V. Bentis, Révision d. Tellinidés, p. 271, No. 100.

NW. of Koh si Chang, 10 fathoms, mud $(1 / 2)$. W. of Koh Chuen, soft clay and mud $(2 / 2)$. Gulf of Rayong, 7-10 fathoms, mud (1/2). S. of Koh Samit, 20 fathoms, mud (6/2). S. of Koh Tulu, 10 fathoms, mud mixed with sand (5/2). Koh Chang, $3-5$ fathoms, soft clay (many specimens). W. of Koh Chang, 20 fathoms, mud ( $1 / 2$ ). S. of Kiol Bidang, 9 fathoms, mud $(1 / 2)$. S. of Koh Mak, $5-6$ fathoms $(1 / 2)$. W. of Koll KuL, 15-30 falhoms, mud ( $\left.{ }^{4} / 2\right)$. Around Koh Kahdat and Koh Kùt, 6-10 fathoms, clay mixed with sand, and mud (many specimens). Around Koh Kong, 8-15 fathoms, mud (7).

Long. 5-16 $\mathrm{mm}$.

Distribution:- Philippines, China, New Caledonia.

Tellina (Peronaea) micans, Hanl.

Tellina micans, HANLEY, Proc. Zool. Soc. London, XII, 1844, p. 72.

Monogr, of the gen. Tellina (Sowersy, Thesaur. Conchyl., I), p. 309, No. 170, pl. 59 , fig. 106 .

- - - L lievve, Conchol. icon., XVII, Tellina, Sp. 130.

- (Peronaea) micans, Hanler, Römsk in Mantini u. Chemniz, Conchyl. Cabin., X Bd., 4 Abtl., p. 120 , No. 71 , pl. 28 , tigs. $5-7$. 
Tellina (Homala) micans, Hanley, Bertin, Révision d. Tellinidés, p: 297, No. 222.

Psammobia micans, Hanley, Edg. SMitr, Ann, and Magaz. Nat. Hist., 7 Ser., XVIII, 1906, p. 260.

Tellina depauperata, v. MArtexs, Ann. and Magaz. of Nat. Hist., 3 Ser., vol. 16, 1865, p.429, No. 4.

Römer in Martini u. Chemsitz, Conchyl. Cabin., X Bd., 4 Abth., p. 254, No. 158 , pl. 49 , figs. $1-3$.

S. of Koh Samit, 20 fathoms, mud (14). W. of Koh Chang, 20 fathoms, mud (1). Sound of Koh Chang, $3-5$ fathoms, soft clay ( $8 / 2$ dead specimens). Koh Kahdat (fragment).

Long. $11-29 \mathrm{~mm}$.

Distribution:- Persian Gulf (Edg. Smitu), Mekran coast (Melvill \& Standen), Aden (Shopland). - Philippines.

EDG. Smith (loc. cit.) thinks that the present species "on account of the absence of lateral teeth and the oblique sculpture" must be referred to Psammobia, but I am convinced that he is wrong in this; the absence of the lateral teeth being typical of the subgenus Peronaea, and the oblique sculpture being found in so many other species of Tellina.

\section{Tellina (Metis) coarctata, Phil.}

Tellina coarctata, R. A. PHilippı, Zeitschrift f. Malakozool., 1845, p. 151, No. 11.

- lacunosa, (non Chemsitz), Hanlex in Sowerby, Thesaur. Conchyl, I, p. 322, No. 197. pl. 65, fig. 252.

- - - - R Reve, Conchol. icon., XVII, Tellina, Sp. 25.

- (Metis) lacunosa, (non Chemnitz), Römer in Martini u. Chemnitz, Conchyl. Cabin., X Bd., 4 Abth., p. 201, No. 120, pl. 38 , figs. $10-12$.

North of Koh Kam, 5 fathoms, gravel (1/2).

Long. $49 \mathrm{~mm}$.

Distribution: - China.

I have specimens at hand labelled "Algoa Bay" and "Senegal."

It seems to me that Puilippr has good reason for doubting whether Cinemitz's lacunosa "from Guinea" is identical with the "lacunosa from China" of later authors; therefore, I have adopted his name coarctata for the latter form. Unfortunately, it is very probable that Chemnrtz's original specimen of lacunosa no longer exists, at any rate it is not to be found in the Zoological Museum of the University of Copenhagen, so actual comparison is impossible; but as Chemnitz's figure and description present many characteristic points which are not to be found in coarctata, I think we have here two distinct species.

It is no doubt due to a mistake that SPEngler ${ }^{1}$ gives "East India" as the locality of his T.ephippium. His original specimens are in the Zoological Museum of the University of Copenhagen, but on the label, in his own handwriting, no locality is given. On comparing SPEngler's original specimens of T.ephippium with specimens of SAY's intastriata ( $=$ T. Gruneri, Plnil. $\left.{ }^{2}\right)$ it is seen that these suecies are absolutely identical, and as SPEnglen's name has the priority, SAY's intastriala and Puncippr's Gruneri should consequently be regarded only as synonyms of

1 Skrivter af Naturhistorie-Selskabet, 4 I3ind, 2 Hefte, 1798, p. 104.

2 From Florida Keys, St. Anna (east coast of Mexico) and from many different localities in the Lesser Antilles, especially the Danish West Indies. 
T. ephippium, Spengler. Puntre' ${ }^{1}$ had already some idea of this when he established his T. Gruneri. ReEve's figure, Sp. 111, of T.ephippium, Spglr., exactly corresponds with Spenglen's original specimens and with T. Gruneri, therefore I fail to see the reason why Röner finds that HANLEY's figure of ephippium is "himmelweit verschieden" from ReEve's-figure; they are almost identical if the figures are placed in the same position.

\section{Tellina (Macoma) candida, Lam.}

Psammotoca candida, Lamarck, Hist. nat. d. anim. s. vert., V, 1818, p. 517, No. 6. - éd. 2, VI, 1835, p. 183, No. 6. Tellina sericina, Jonas, Philrppi, Abbild. u. Beschreil. nener od. wen. gek. Conchyl., I, (1843), p. 71, No. 1, Tellina, pl. 1, fig. 1.

- Galataa, Hanley in Sowerby, Thesaur. Conchyl., I, p. 301, No. 154, pl.64, fig. 223 (non T. galatca, Lamarck).

- Galalhaea, Rerve, Conchol. icon., XVII, Tellina, Sp. 102 (non T.galatar, Lamarck).

- (Macoma) Galatea, Römer in Martin u. Chemeitz, Conchyl. Cabin., X 13d., 4 Abth., p. 249, No. 154, 1. 47. figs. 7-9 (non T. galatoca, Lamarck).

Macoma candida, Lamarck, V. Bertin, Révision d. Tellinidés, p. 342, No. 27.

Coast of Lem Ngob, low tide (1/2). Sound of Koh Chang, 3-5 fathoms, soft clay $(1+21 / 2)$. W. of Koh Chang, 30 fathoms (1). Between Koh Kut and Koh Kahdat, 10 fathoms, shells $(2 / 2)$. W. of Koh Kut, 30 fathoms, sand and mud $(2 / 2)$. Long. $10-46 \mathrm{~mm}$.

Distribution: - "Am Eingang d. Golfs v. Siam in 16 Faden" (E. v. Marters). Philippines, China, Japan, Moluccas, Java, 'Timor, Australia.

All the specimens from the Gulf of Siam are entirely destitute of the granulated sculpture characteristic of galatoa (Hanley); at first I determined them as belonging to a form near to $T$. candida; but on account of the confusion which has prevailed within this group (and which V. BERTIN has but partially dispersed) I asked Mr. Edg. Sмiти to be kind enough to compare them for me, and he determined them as $M$. candida, Lam., "in which the peculiar granose epidermis is obsolete. T. arafurensis, Smith, is different in form." Hanley (Proc. Zool. Soc. London, XII, 1844, p. 147) has described, under the name of $T$. Diana, a form of his galatea with a smooth surface, and it must undoubledly be this variety to which the specimens from the Gulf of Siam are most closely allied.

\section{Tellina (Macoma) papyracea, Spengl.}

(Pl. III, Figs. 50-52),

Tellina papyracea, SPExGlek, Skrivter af Naturhistorie-Selskabet, 4de 13d., 2det Hefte, 1798, p. 98, No.25.2 gubernaculum, HanleY, Proc. Zool. Soc. London, XII, 1844, p. 142.

Sowerby, Thesaur. Conchyl., I, p. 325, No. 201, pl. 62, fig. 186.

RIEVE, Conchol. icon., XVII, Tellina, Sp. 181.

(Macoma) Gubernaculum, Haniex, Römer in Martini u. Chemvitz, Conchyl. Cabiu., X Bd., 4 Abth., p. 247 , No. 152, pl. 47 , tigs. $1-3$.

Macoma gubernaculum, Havily, V. Bentr, Révision d. Tellinidés, p. 344, No. 31.

1 Ablild. u. Beschreib. neuer od. wen. gek. Conchyl., III, p. 56.

Gmelin's Tellina papyracea $=$ Tellina (Metis) lacunosa, Ch. SPEnglen quotes: Lister, Hist. Conch., pl. 395, fig. 242 as a synonym of his $T$. papyracea; this figure according to MöncH, resembles more closely SPENGLER's T. sinuata. 
The sound of Koh Cliang, 3-5 fathoms, soft clay (3/2). N. of Koh Kong, 8 fathoms, mud (1/2).

Long. 14-48 mm. - (Long. $48 \mathrm{~mm}$., alt. $37 \mathrm{~mm}$., crass. $14 \mathrm{~mm}$.) - (Long. $44 \mathrm{~mm}$., alt. $31 \mathrm{~mm}$., crass. $15 \mathrm{~mm}$.).

Distribution:- Tranquebar (Spengler and Seidelin, Zool. Mus. Copenhagen), Manilla (Zool. Mus. Copenhagen). Eog. Suru writes to me: "I think 'Central America,' the locality given by HANLEY (T.gubernaculum) is a mistake. We have it from Bombay." I believe here reference is made to the specimens from Bombay determined by Melvill and Abercrombie ${ }^{1}$ as Macoma truncata, Jonas. As M.truncata, Jonas, is easily mistaken for the species we are here considering, some of the localities given for truncuta should undoubtedly be transferred to T.papyracea, Spengl.

As the original specimens of Spenglen's papyracea are in the Zoological Museum of the University of Copenhagen it has been possible for me to verify the fact that the specimens from the Gulf of Siam belong to the same species. I sent some of the specimens from the Gulf of Siam to Mr. Eng. Smitr, and he kindly informed me that they "agree with gubernaculum of Hanley;" consequently, it is proved that Hanley's species should be regarded as a synonym of SPENGLER's papyracea, which name has the priority. MörcH ${ }^{2}$ states that T.truncata, Jonas, is identical with T.papyracea, Spengl., but this is certainly wrong; truncata, according to Jovas's diagnosis, presents several peculiarities which are undoubtedly characteristic of that species.

\section{Tellina (Macoma) fallax, Bertin.}

Macoma fallax, V. Bentin, Révision d. Tellinidés (Nouv. Archives du Muséum d'Histoire Naturelle, 2 Sér., I, Paris), 1878, p. 343, No. 29, pl. 8, fig. 4.

Sound of Koh Chang, 3-5 fathoms, soft clay ( $29 / 2)$. Between Koh Kahdat and Kol Kut, 6 fathoms, clay mixed with sand $(19 / 2)$.

Long. 5-29 mm. (long. $29 \mathrm{~mm}$, alt. $17 \mathrm{~mm}$., crass. $12 \mathrm{~mm}$.).

Distribution unknown.

Although the shells from the Gulf of Siam do not reach the size of that figured by BERTIN, and although BERTIN's brief diagnosis is not of much use as a guide, I think I can safely refer my individuals to the present species, which has undoubtedly often been confused with T. candida, Lam.

Tellina (Macoma) lilium, Hanl.

(Pl. IV, Figs. 1-2)

Tellina Lilium, HaNuey, Proc. Zool. Soc. London, 1844, p. 147.

- lilium, - Hanley in Sowerby, Thesanr. Conchyl., I, p. 303, No. 158, pl. 58, fig. 85.

- - - Reeve, Conchol. icon., XVII, Tellina, Sp. 174.

1 Mem. and Proc. of the Manchester Liter. and Phil. Soc, 4 Ser, vol. VII, p. 50.

2 Malakozoolog. Blätter, XVII, 1870, p. 116. 
Tellina Lilium, Hanley, Römer in Martini u. Chemnitz, Conchyl. Cabin., X Bd., 4 Abth, p. 253, No. 157, pl. 48 , figs. $4-6$.

Macoma líim, Hanley, V. Bertin, Révision d. Tellinidés, p. 337, No. 12.

Lilium, - Hidalgo, Fauna malacol de 1. Isl. Filipinas, II, 1903, p. 160, No. 279.

Tellina donaciformis, Deshayes, Proc. Zool. Soc. London, 1854, p. 357, No. 182.

donaciniformis, - ReEve, Conchol. icon., XVII, Tellina, Sp. 299.

- Homala) donaciformis, Deshayes, V. Bertin, Révision d. Tellinidés, p. 290, No. 178.

(Donax) Tellina Essingtonensis, DeshaYes, ReEve, Conchol. icon., XVII, 1866, Tellina, Sp. 73.

Macoma Essingtonensis, Deshayes, V. Bertin, Révision d. Tellinidés, p. 342, No. 26.

E. of Koh Mak, 20 fathoms, mud (1/2). Between Koh Kut and Koh Kahdat, $6-10$ fathoms, clay and shells $(2+6 / 2)$. W. of Koh Kut, 30 fathoms, sand and mud $(6 / 2)$.

Long. $10-18 \mathrm{~mm}$.

Distribution:- Singapore (2-3 fathoms, Danish Exp. to Siam). - Philippines, Torres Strait, Port Essington, Lane Cove (Port Jackson), Isl. Ravvak (Freycinet).

\section{Tellina (Macoma) Moluccensis, Mart.}

Tellina Moluccensis, E. v. Martens, Annals and Magaz. of Nat. Hist., 3 Ser., vol. 16, 1865, p.430, No.5.

- (Metis). Moluccensis, E. v. Matrens, Römen in Martin u. Chemnitz, Conchyl. Cabin., X Bd., 4 Abth. p. 213, No. 129, pl. 41 , figs. $4-6$.

Metis Moluccensis, E. v. Martens, V. Bertin, Révision d. Tellinidés, p. 332, No. 13.

Surface mud along the coast of Lem Ngob, low tide (1/2). Coast of Lem Ngob, low tide, stones $(\widetilde{2} / 2)$.

Long. $17 \mathrm{~mm}$., alt. $13 \mathrm{~mm}$.

Distribution:- Moluccas.

I have referred the present species to the subgenus Macoma; it is difficult to understand why previous authors have referred it to the subgenus Metis.

\section{Tellina (Macoma) tenuisculpta n. sp.}

(PI. IV, Figs. 3-5).

The valves of this species are triangular in form, white and rather thin, and compressed; they are somewhat gaping at the ends, epecially the posterior end. The umbones are situated at about the middle of the axis of the shell, the upper margin slopes abruptly down on both sides, the posterior end is prolonged somewhat in an acute, rostrum-like manner, and the ventral side is gently curved. The different individuals exhibit a more or less distinct "Tellina-curvature." The surface is covered with narrow, close-sel, finely crenulated, concentric, raised lines which are irregular and at different mutual distances. The interstices between the concentric strix are closely sel with fine, irregular radial folds and strix which are not all equally fine; this sculpture gives a rough appearance to the surface. The interior of the valves is white and somewhat glossy. The right valve has two cardinal teeth of which the hinder is the larger and is bifid; the left valve has also two cardinal teeth, the anterior is stout and hifid while the posterior is slender. The 
pallial sinus ascends from the posterior muscle-impression upwards in a curve and then descends obliquely down towards the pallial line, which it meets somewhat before the pallial line has reached the anterior muscle-impression.

Long. $9 \mathrm{~mm}$., alt. $6.5 \mathrm{~mm}$., crass. $3.5 \mathrm{~mm}$.

North end of Koh Chang, 1 fathom, coral blocks $(2+10 / 2)$. North end of Koh Chang, 12 fathoms, old coral blocks $\left(1+{ }^{10} / 2\right)$. West coast of Koh Chang, 1 fathom, old coral blocks (2/2). South-west end of Koh Chang, 1 fathom, corals (1/2). Koh Kahdat, 1 fathom, sand ( $1 / 2)$. Koh Kahdat, $1-2$ fathoms, corals $(1 / 2)$.

This species is most closely allied to the group:-- M. inquinata, Desh., nasula, Conr., constricta, Brug., etc. It is, however, easily distinguished from them by its characteristic sculpture. It varies considerably in form, which is no doubt due to its inhabiting old coral blocks. In the material collected are several individuals which are more ovate-oblong in form than the above description indicates; but this is more particularly the case with the younger individuals, almost all of which are more oblong than are the (apparently) full-grown ones.

\section{Fam. Psammobiidae.}

\section{Asaphis defforata L.}

Venus deflorata, Linné, Systema Naturae, ed. X, 1758, p.687, No. 108. - ed. XII, p. 1133, No.132. - ed. XIII cur. GuELIN, p. 3274 , No. 24.

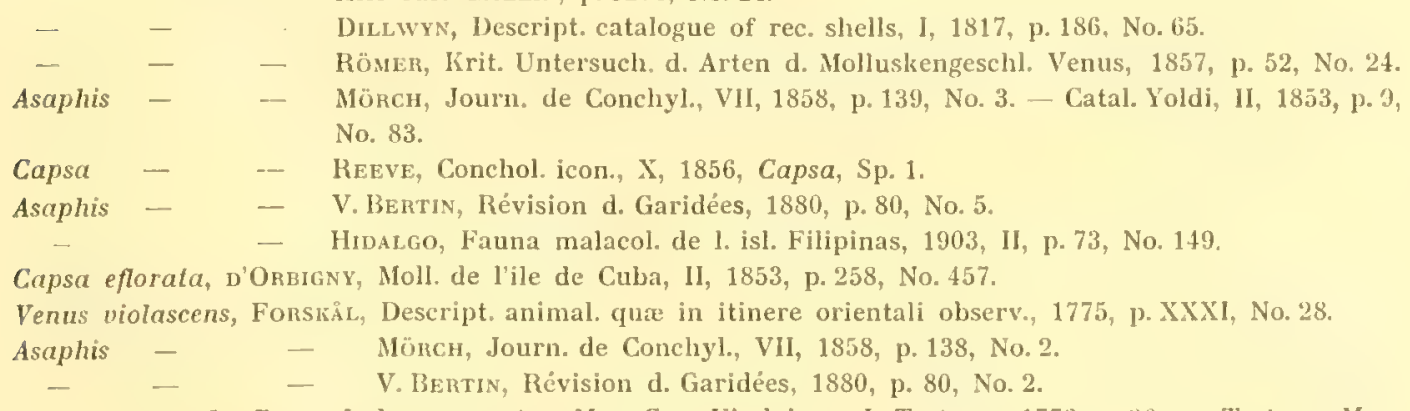

Tellina anomala, Bons, Index rer. natur. Mus. Cres. Vindobon., I, Testacea, 1778, p. 20. - Testacea Mís. Cas. Vindobon., 1780, p. 31.

- - - - Chemnitz, Conchyl. Cabin., VI, 1782, p. 93, pl. 9, figs. 79-82.

Cardiuni coccinea, Manty, The Universal Conchologist, 1784, No. 135.

Asaphis - - Mörch, Journ. de Conchyl., VII, 1858, p. 140, No. 4.

- _ _ V. Bertin, Révision d. Garidées, 1880 , p. 79, No. 1.

Dall and Simpson, The Mollusca of Porto Rico, 1901, p. 476.

Venus versicolor, GMelin, Systema Naturae, 1790, p. 3281, No. 63.

- purpurata, - loc. cit., p.3289, No. 100, (Monstr.?).

Capsa rugosa, Lamarck, Systême d. anim. s. vert, 1802, p. 125.

Sanguinolaria rugosa, LAMAkck, Hist. nat. d. anim. S. vert., V, 1818, p. 511, No. 4. - éd. 2, VI, 1835,

Capsula $\quad$ P. 170, No. 4.
Schumacien, Essai d'un nouv. syst. d. habit. d. vers. test., 1817,1 p.
$130-31$, pl. 9, fig. 1.

Psammobia - - - Sowenis, Genera of shells, No. 35, pl. 55, fig. 1. 
Psammocola rugosa, Lamanck, BLainville, Manuel de Malacologie, 1825 , p. 564.

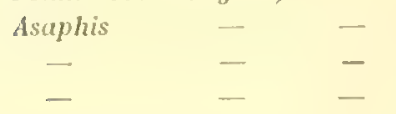

Morlet, Journ. de Conchyl., vol. 37, 1889, p. 172, No. 84.

P. Fischeß, Moll. de I'Indo-Chine, p. 241.

E. v. Mantens, Süss- u. Brackwasser-Moll. d. Indischen Archipels, 1897, p. 252.

Sanguinolaria dichotoma, Anton, Verzeichn. d. Conchyl. in d. Samml. v. H. E. Axton, 1839, p.4, No. 123. Asaphis - - Möcil, Journ. de Conchyl., VII, 1858, p. 138, No.1.

Sanguinolaria - _ - V. Bentin, Révision d. Garidées, 1880, p. 80, No. 4 (Asaphis arenosa, IRแmนh. .

Asaphis - - Hidalgo, Fauna malacol. de 1. isl. Filipinas, 1903, II, p. 74, No. 150.

- - _ - Dautzenberg et Fischer, Journ. de Conchyl, vol. 53, 1905, p. 233.

Koh Chang ( $1 / 2)$. Coasts of Koh Chang $(5 / 2)$. Koh Lom (13). Koh Mak, sandy coast ( $3 / 2)$. Strand of Koh Kalidat (1/2).

Islands in the Gulf of Siam (MORLET).

Long. 8-74 mm.

Distribution:- Singapore, Salang, Mergui Isls., Andamans, Nicobars, Tranquebar, Ceylon, Maldive Isls., Karachi, Bombay, Persian Gulf, Aden, Red Sea, Suez, Zamzihar, Amirantes, Seychelles, Madagascar, Mascarenes. -- Poulo Condor, Tonkin, Hong Kong, Japan, Loo Choo Isls., Philippines, Sumatra, Java, Moluccas, Flores, Timor, Aru Isls. (and several localities in the Malay Archip.), New Guinen, Salomon Isls., Torres Strait, North and East Australia, New Caledonia, New \%ealand, Mariannes, South Sea Isls. - Bermuda Isls., Florida, Vera Cruz, Mexico to Brazil, Greater and Lesser Antilles.

I have at my disposal a great number of specimens of Asaphis deflorala from different West Indian localities, but it has not been possible for me to find constant characters which would distinguish them from individuals from East Indian habitats.

\section{Psammobia scabra, Chemu.}

Tellina scabra, Chlinnitz, Conchyl. Cabin., VI, 1782, p. 102, pl. 10, fig. 94.

Psammobia scabra, Chesintrz, E. v. MAntexs, Süss- u. Brackwasser-Mollusken d. Ind. Archipels, 1897, p. 248, No. 12.

maculos $\alpha$, LaMarck, Hist. uat. d. anim. s. vert., V, 1818, p. 513, No.5. - cd. 2, V1, 1835, p. 174. No. 5.

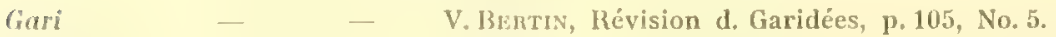

P'summobia ornala, Desidayes, Proc. Zool. Soc. London, XXII, 1854, p. 323, No. 27.

- $\quad$ ReEve, Conchol. icon., X, Psammobia, Sp. 26.

Gari -- - V. Ilentin, Revision d. Garidées, p. 105, No. 8.

Psammobia - - Hidalgo, Fauna malacol. de 1. isl. Filipinas, 1I, p. 77, No. 154.

- rubicunda, - Proc. Zool. Soc. London, XXII, 1854, p. 324, No. 30.

- $\quad$ - ReEve, Conchol. icon., X, Psammobia, Sp. 34.

Gari - - V. Brntis, Révision d. Garidées, p. 105, No.6.

P'sammobia - - Hiddego, Fauna malacol. d. 1. isl. Filipinas, II, p. 76, No. 152.

$\begin{array}{lcc} & \text { corrugala, } & - \\ \text { Gari } & - & - \\ \text { Psammobia } & - & - \\ & - & -\end{array}$ Proc. Zool. Soc. London, XXII, 1854, p. 324, No. 31.

lievers, Conchol. icon., X, Psammobia, Sp. 9. V. Bentin, Révision d. Garidées, p. 105, No. 7. Dunker, Index molluscor. mar. Japon., 1882, p. 187. Hidalgo, Founa malacol. de 1. isl. Filipinas, 11, p. 76, No. 153. 
Psammobia marmorea, Deshayes, Proc. Zool. Soc. London, XXII, 1854, p. 324, No. 32.

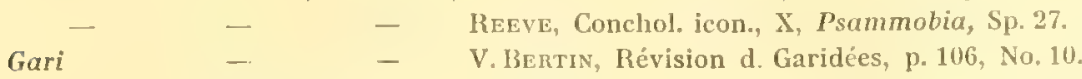

South of Koh Chuen, 30 fathoms, shells (fragment). Between Koh Mesan and Kol Chuen, 25-38 fathoms, stones with shells $(1 / 2)$.

Long. $42 \mathrm{~mm}$.

D istribution: - Andamans, Ceylon, Persian Gulf, Muscat (Arabia), Gulf of Aden, Comoro, Madagascar, Zanzibar, Durban (S. Africa). - Philippines, Japan, Moluccas, Torres Strail, east and south coasts of Australia, New Caledonia, Darnley Isl., Viti Isls., Tahiti.

\section{Psammobia zonalis, Lam.}

Psammotea zonalis, LAMArck, Hist. nat. d. anim. s. vert., V, 1818, p. 517. No. 2. - ẻd. 2, VI, 1835, p. 182, No. 2.

Psammotea - - Delessert, Recueil de coquilles décr. p. Lamarck, 1841, pl. 5, fig. 9.

Psammobia - - Reeve, Conchol. icon., X, Psammobia, Sp. 29.

Gari - - V. Bentin, Révision d. Garidées, p. 109, No. 27.

Psammobia - - - EDG. Smith, Lamellibranchiata of the Challenger Exped., pp.94, (and 93).

Gari - - Pritchand and GathlfF, Proc. Roy. Soc. Victoria, vol. 16, 1903, p.113.

Psammabia radiata, Dunker in PhulppI, Abbild. u. Beschreib. neuer od. wen. gek. Conchyl., I, 1845, p. 194 , No. 3, pl. 2, fig. 5 .

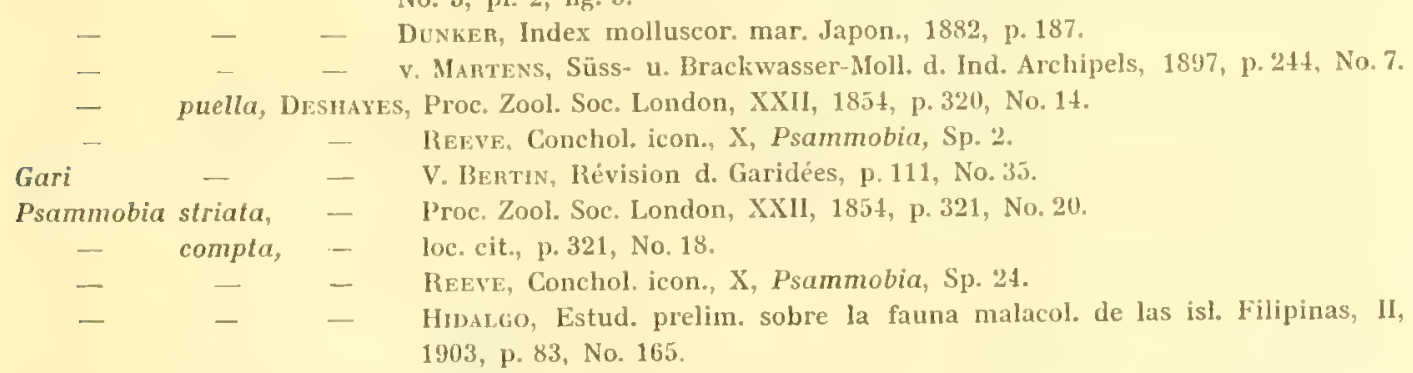

Gari - - V. Bertin, Révision d. Garidées, p. 110, No. 34.

Psammobia amethystus, Rejve (non Wood), Rerve. Conchol. icon., X, Psammobia, Sp. 19.

- Tellinceformis, Deshayes in REEve, loc. cit., Sp. 31.

- - - V. Bentix, Révision d. Garidées, p. 109, No. 26.

Between Koh Mesan and Cape Liant, 5-9 fathoms (2). North of Koh Kahdat, 4-5 fathoms, coarse sand ( ${ }^{1 / 2}$ ). Koh Kahdat, 1 fathom, sand (1).

Long, 20-41 $\mathrm{mm}$.

Distribution: - Ceylon. - Japan, Loo Choo Isls., Philippines, Moluccas, Java, east and south coasts of Australia, Tasmania, New Caledonia.

The specimens from the Gulf of Siam exactly agree with $P$. compta, Desh. I rely upon Edg. Smitu's authority (loc. cit.) in referring this species to P. zonalis, Lam.

Psammobia tenuis, Desh.

Psammobia tenuis, Deshayes, Proc. Zool. Soc. London, XXII, 1854, p. 320, No. 16. ReEve, Conchol. icon., X, Psammobia, Sp. $37 \mathrm{~b}$ (non $37 \mathrm{a}=P$. anomala, Desh. var.). 
Gari tenuis, Deshayes, V. Bertiv, Révision d. Garidées, p. 110, No. 30.

Psammobia tenuis, Deshayes, Hidago, Estud. prelim. sobre la fauna malacol. de las isl. Filipinas, II, p. 82 , No. 164 .

N. of Koh Kahdat, 4-5 fathoms, coarse sand (1). Koh Kahdat, 1 fathom, sand (3). W. of Koh Kut, 30 fathoms, sand and mud $(3 / 2)$.

Long. 5-25 $\mathrm{mm}$.

Distribution: - Philippines.

The specimens from the Gulf of Siam are pink in colour.

Psammobia anomala, Desh.

Psammobia anomala, Deshayes, Proc. Zool. Soc. London, XXill, 1854, p. 320, No. 15.

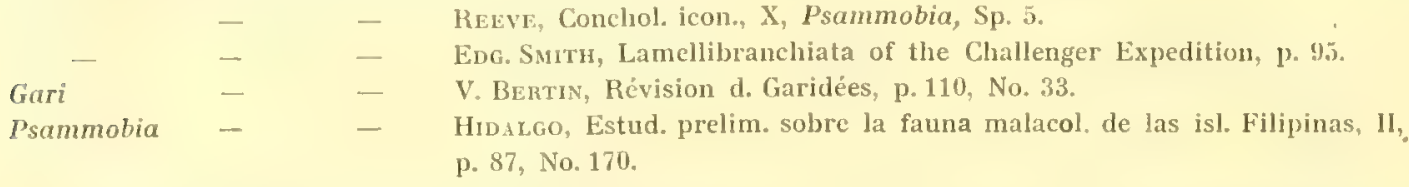

Gulf of Rayong, 7-10 fathoms, sand, mud (1/2). Koh Chuen, 30 fathoms (1). Between Koh Kut and Koh Kahdat, 10 fathoms, shells (1/2).

Long. $19-23 \mathrm{~mm}$.

D istribution:- Madras. - Philippines, Japan, Borneo, Torres Strait, north and east coasts of Australia.

\section{Psammobia simplex, Sow.}

(Pl. IV, Figs. 6-S).

Psammobia simplex, G. 13. Sowerby, Proceed. Malacolog. Soc. London, I, 1894 (1895), p. 159, pl. 12, lig. 21.

Gulf of Rayong, 7-10 fathoms, sand and mud $(1+1 / 2)$. Around Koh Kahdat, S-10 fathoms, mud $\left({ }^{9} / 2\right)$. Between Koh Kut and Koh Kahdat, 10 fathoms, shells $\left({ }^{6} / 2\right)$. South and west of Koh Kut, 15-20 fathoms, mud $(1+2 / 2)$. N. of Koh Kut, 10 fathoms, mud $(4 / 2)$.

Long. 5-14 mm. (long. $14 \mathrm{~mm}$., alt. $8 \mathrm{~mm}$.).

Distribution: - Singapore (Sv. GAD, shallow water; $3 / 2$ valves). Karachi (Melvill \& Standen), Hong Kong (Sowerby).

SowERBY gives "Longit. 9, alt. $5 \mathrm{~mm}$." as the measurements of his specimens; those from the Gulf of Siam are of larger dimensions; they are of a pure white colour.

\section{Elizia orbiculata, Wood.}

Solen orbiculalus, Woop, Index Testaceologicus, 1828, Supplem. p. 3, No. 4, pl. 1, fig. 4.

Psammobia orbicularis, Deshares, Magazin de Zoologie p. Guérin-Méneville. Mollusques, 1839, pl. 7.

Soletellina orbiculata, WoOD, ReEve, Conchol. icon., X, Soletellina, Sp. 18.

Elizia - - AdAss, Genera of recent Mollusca, II, p. 393, pl. 103, tìg. 5.

- orbicularis, - Bertin, Révision d. Garidées, p. 129, No. 2.

- orbiculata, - J. DE Morgax, 13ull. de la Soc. Zool. de France, X, 1885, p. 366, No. 26.

- - - E. v. Martens, Süss- u. Brackwasser-Moll. d. Ind. Archip., p. 233.

Soletellina reversa, RLEvis, Conchol. icon., X, Soletellina, Sp. 17. 
Siam (J. de Morgan).

The Danish Expedition to Siam collected no specimens of this species.

Distribution: - Malacca, Singapore, Poulo-Penang. - Borneo, Sumatra.

\section{Soletellina Chinensis, Chemn.}

Solen Diphos Chinensis, Chemsirz, Conchyl. Cabin., XI, 1795, p. 200, pl. 198, fig. 11933.

Solenotellina chinensis, _ _ Mörcr, Catal. conchyl. quæ rel. com. de Yoldi, II, 1853, p. 9, No. 88. - Chinensis, - Dunker, Index moll. mar. Japon., 1882, p. 187.

Soletellina chinensis, - E. v. Martens, Süss- u. Brackwasser-Moll. d. Ind. Archip., p. 233.

- truncata, ReEvE, Conchol. icon., X, Soletellina, Sp. 9.

- - GMFim?, E. v. Martens, Proc. Zool. Soc. London, 1860, p. 18.

- planulata, ReEve, Conchol. icon:, X, Soletellina, Sp. 15.

Hiatula - - _ BrntiN, Révision d. Garidées, p. 87, No.8.

Siamı (ED. v. Martens).

The Danish Expedition to Siam collected no specimens of this species.

Distribution:- China, Japan, Moluccas.

Psammotaea violacea, Lam.

Psammotcea violacea, Lamarck, Hist. nat. d. anim. s. vert., V, 1818, p. 517, No.1. - éd. 2, VI, p. 181 , No. 1. - - - - Hanley, Catal. of rec. biv. shells, p. 60, Suppl. pl. 12, fig. 60.

Capsella - ReEve, Conchol. icon., X, Capsella, Sp. 6.

- - - - E. v. Martens, Proc. Zool. Soc. London, 1860, p. 18.

Hiatula (Psammotca) violacea, Lamarck, V. Bertin, Révision d. Garidées, p. 96, No. 34.

Psammotaea violacea, Hanley, E. v. Martens, Süss- u. Brackwassel-Moll. d. Ind. Archip., p. 239, No. 2.

Psammotea - Lamarci, Hidalgo, Fauna malacol. de l. isl. Filipinas, 11, p. 95, No. 186.

Soletellina, - - Melvili, \& Standen, Proc. Zool. Soc. London, 1906, 13.84\%.

Psammotea serotina, - Hist. nat. d. anim. s. vert., V,'1818, p.517, No. 5. - éd. 2, VI, p. 182 , No. 5.

Siam (ED. V. MaRTENS).

The Danish Expedition to Siam collected no specimens of this species.

Distribution: - Karachi (Melyll \& Standen), Zanzibar (L. Rousseau according to V. Bertin), Seychelles. ${ }^{1}$ - Hong Kong, Formosa, Japan, Philippines, Java, Amboina, Adenare, New Guinea, Kei-Isl., New Caledonia.

E. v. MARTEns doubts whether LAMARci's violacea is the same species as that of HANLEY and other authors; V. BERTIN, who had LAMARCK's original specimens for comparison does not, however, mention anything about this and gives them as synonyms.

\section{Fam. Scrobiculariidae.}

Semele amabilis, A. Ad.

Semele amabilis, A. Adams, Proc. Zool. Soc. London, 1853, p. 97, No. 17.

Amphidesma amabilis, A. Adams, Conchol. icon., V111, Amphidesma, Sp. 32..

Semele - EDg. Smith, Rep. on the Lamellibranchiata of the Challenger Lxped., 1. 83.

I Recorded from there by DuFo, L. Rousseau and LANTz (V. BerTiN); En, v. Mairtens thinks that this is perhaps due to confusion, on the part of Dufo, with P. radiata, Desh. 
Gulf of Rayong, 7-10 fathoms, sand and mud (3). Between Koh Chuen and Kolı Chang, 15 fathoms, mud (1). Koh Kahdat, 1-5 fathoms, sand with stones (1). Between Koh Kut and Koh Kahdat, 10 fathoms, shells (1/2).

Long. 13-33 mm. (Long. $33 \mathrm{~mm}$, alt. $29 \mathrm{~mm}$., crass. $12 \mathrm{~mm}$.).

Distribution:- Arafura Sea (Challenger), Port Curtis (A. Adnas).

The concentric lamella upon the surface are placed more closely together than is indicated in ReEve's figure. Eog. Shith (loc. cit.) gives an excellent and exhauslive diagnosis of this comparatively large and beautiful species, which strangely enough, has hitherto been obtained from so few localities.

Semele casta, A. Ad.

Semele casta, A. Adass, Proc. Zool. Soc. London, XXI, 1853, p. 96, No. 15.

Amphidesma casta, A. Anams, ReEve, Conchol. icon., VIII, Amphidesma, Sp. 18.

Koh Chuen, 30 fathoms $(1 / 2)$. Between Koh Chuen and Koh Chang, 15 fathoms, mud (1). South-west end of Koh Chang, 1 fathom, corals (1). Koh Mak, sandy coast (1).

Long. $11-25 \mathrm{~mm}$.

Distribution:-- Gulf of Manaar (Tiunston). - Moreton Bay (Australia, STRANGE).

The sculpture at the umbo differs from that of the rest of the shell, the distance between the first $7-8$ concentric ribs being greater and the interstices between them being nearly smooth, almost quite without the radiating sculpture which is found upon the rest of the shell.

Note. Semele Jukesi, A. Ad., and Semele cxarata, Ad. \& Reeve, have been laken at Singapore in shallow water by Mr. Sv. GAD.

Theora lata, Hinds.

(P'. IV, Figs, 9-11).

Neara lala, Hinvs, proc. Zool. Soc. London, XI, 1843, p. 79.

Theora - - H. \& A. Adams, Gen. of rec. Moll., II, p. 370, pl. 97, fig. 5.

- - Hibalgo, Fauna malacol. de 1. isl. Filipin., 11, 1903, p. 71, No. 146.

Vecera fragilis, A. Abams, Proc. Zool. Soc. London, XXIII, 1855, p. 226, No. 25.

Theora - - Ann. and Mag. Nat. Hist., 1864, p. 209.

- Hedler, Proc. Linn. Soc. New South Wales, 1901, XXVI, p. 706, pl. 34, figs.4-6.

Sound of Koh Chang, 3-5 fathoms, soft clay ( $\left.{ }^{45 / 2}\right)$. The strand of the Mangrove at the station on Koh Chang $(1 / 2)$. Between Koh Kut and Koh Kaldat, 10 fathoms, shells (5). North of Koh Kong, 8 fathoms, mud (15).

Long. $35-20 \mathrm{~mm}$.

Distribution:- Gulf of Manaar. - Philippines, Niegata (Japan), Cardwell (Queensland), Moreton Bay, Lane Cove (Sydney).

After having compared in the British Museum, T.lata, Hinds, with T. fragilis, A. Ad., I see no reason for separating these two forms and making distinct species of them. 
Leptomya spectabilis, Hanl.

Leptomya speclabilis, Hanlex, Proc. Zool. Soc. London, 1882, p. 576.

- - - Joum. Linnean Society, Zoology. XVI, 1883, p.511, pl. 12, fig. 7.

South of Koh Mak, 5-6 fathoms ( ${ }^{1 / 2}$ ).

Long. $3.5 \mathrm{~mm}$.

D istribution:- Japan(?).

In spite of the small size of the specimen, I do not doubt that the determination is correct.

\section{Fam. Donacidae.}

Donax (Hecuba) acuticarinatus, Sow.

Donax acuficarinatus, Sowerby, Thesaur. Conchyl., III, 1866, p. 305, No. 3, pl.280, figs.6-7.

(Ilecuba) acutocarinatus, Sowenßy, V. Bentw, Révision d. Donacidées, p. 81, No.6.

- acutocarinatus, Sowerby, P. Fischer, Catal. d. Moll. de l'Indo-Chine, p. 240.

"Siam" (SowERBy).

The Danish Expedition to Sian collected no specimens of this species.

Donax (Serrula) incarnatus, Chemn.

([)]. IV, Figs. 12-13).

Donax incarnata, Chemnitz, Concliyl. Cabin., VI, 1782, p. 265, pl. 26, fig. 259.

- - - ReEve, Conchol, icon., VIII, Donax, Sp. 53.

-. incarnatus, - Soweriy, Thesaur. Conchyl., III, p. 311, No.43, pl.283, figs. 98-99.

- (Serrula) incarnatus, Chemnitz, Römer in Martini u. Chemnitz, Conchyl. Cabin., X Bd., 3 Abth., p. 76 , No. 47 , pl. 2, fig. 11 ; pl. 13 , figs. $9-12$.

V. Bertin, Révision d. Donacidées, p. 90, No. 26.

- incarnatus, Chemsitz, Dautzenberg \& Fischer, Journ. de Conchyl., vol. 53, 1905, p.468. - vol. 54, 1906 , p. 219 .

- Dysoni, Deshayes, Proc. Zool. Soc. London, XX1I, 1854, p. 353, No. 167.

- _ _ ReEve, Conchol. icon., VIII, Donax, Sp. 54.

- (Serrula) Dyjsoni, Deshaves, Rōmer in Martixi \& Chemnitz, Conchyl. Cabin., X Bd., 3 Abth., p. 69 , No. 42 , pl. 12, figs. 8 - 10 .

V. Bertin, Révision d. Donacidées, p. 90, No. 27. (non D. Dysoni, Lischke $=D$. semigranosus, $\mathrm{Dkr}$.).

"Siam" (SowErBy).

The Danish Expedition to Siam collected no specimens of this species.

Distribution: - Malacca, Tranfuebar, Malabar Coast, Bombay. - Annam, Cochin China.

It is doubtful whether the authors (e.g. Römen) have really had CHemnitz's species incarnatus for examination, Römer writes that REEve does not indicate the same species by the name incarnatus, as that to which he himself has applied that name, and he is undoubtedly right in this. SPENGLer's specimens of $D$. incarnatus from Tranquebar (determined by him as D. muricata L.) are in the Zoological Museum of the University of Copenhagen; they precisely agree with Chemnitz's figure of incarnatus. 
I quite agree with J. C. Mecvil and Arencronisie when they write ${ }^{1}$ that: "D. Dinsoni appears to be incarnatus in a young form."

\section{Donax (Serrula) nitidus, Desh.}

Donax nitida, Desuayes, Proc. Zool. Soc. London, XXII, 1854, p. 350, No. 153.

- - _ Reve, Conchol. icon., VIII, Donax, Sp. 34.

- (Sertula) nitidus, Deshayes, Römer in Mantini u. Chemeitz, Conchyl. Cabin., X Bd., 3 Abth., p. 51 (non D. nitidus, Sowerby, Thesaur. Conchyl., fide Edg. Sмiтu).

- - - _ _ V. Beirtin, Révision d. Donacidées, p. 88, No. 21.

- nilidus, Deshayes, EDg. Sirth, Lamellibranchiata of the Challenger Expedition, p. 112.

Between Koh Rin and Cliff Rock, 15 fathoms (1/2). N. of Koh Kam, 5 fathoms, gravel (1/2). Between Koh Mesan and Cape Liant, $5-9$ fathoms, sand (1/2). W. of Kolı Kul, 15 fathoms (1/2).

Long. $3-10 \mathrm{~mm}$.

Distribution:- Karachi and Mekran Coast (Melvit \& Standen). - Cape York, Moreton Bay, Port Jackson (Sydney).

\section{Donax (Latona) cuneatus L.}

Donax cuneala, Linné, Systema Naturae, ed. X, 1758, p. 683, No. 87 (p. p.). - ed. XII, p. 1127, No. 108. Mus. Lud. Ulrica reg., p. 495, No. 52.

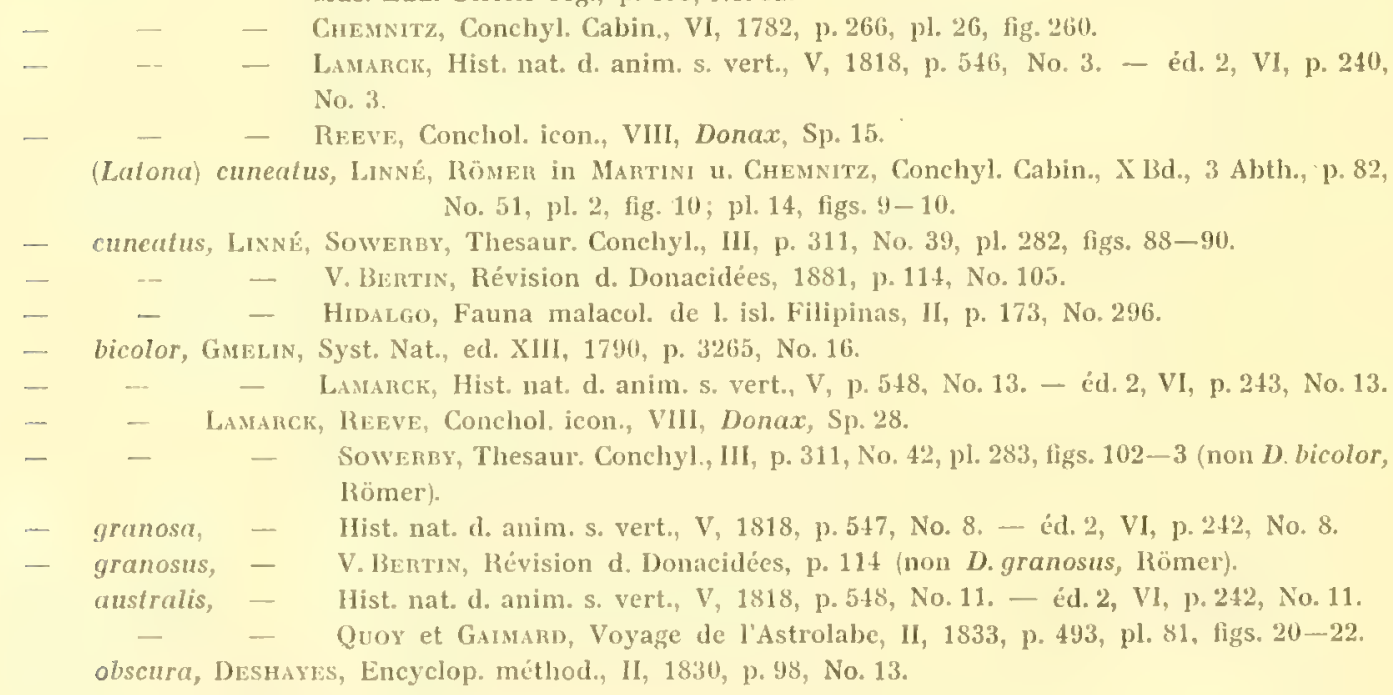

Koll Kahdat, 1 fathom, sand (17). Koh Mak, sandy coast $\left(4+{ }^{4 / 2}\right)$. Long. $15-28 \mathrm{~mm}$.

Distribution:- Andamans, Coromandel Coast, Ceylon, Seychelles and Amirantes, Madagascar, Mascarenes, Zanzibar. - Poulo Condor, Philippines, Japan, Amboina, Timor, New Guinea, Bismarck Archip., New Caledonia, Lifu, Viti Isls., Samoa Isls.

1. The marine Mollusen of Bombay (Mem. and Proceed. Manchester Lit. and Phil. Soc., 4 Ser. vol. VII), 1, 47 
The specimens from the Gulf of Siam exhibit, as is always the case in this species, great variation in their coloration; there are specimens which are, almost entirely white, and individuals in which the rays are slightly indicated, also forms in which the rays are very definite, and dark brown, lilac, etc in coloux. Römen's D. Deshayesii (Dkr.) is scarcely Dunker's species; it is more probably a form of D. cuneatus, and this V. BERTIN and Hidalgo also think. Zelebor's Donax (Latona) granosus $^{1}$ from Amboina does not belong to the present species; as far as I can see it is nearer to D.euglyptus, Dkr. $(=D$. compressus, Lam. $)$, at any rate it is not LAMARCK's granosus.

Donax (Latona) faba, Ch.

Donax Faba, Chemnitz, Conchyl. Cabin., VI, 1782, p. 270, pl.26. figs. 266-67.

- - _ Sowraby, Thesaur. Conchyl., 111, 1866, p. 312, No.45, pl. 283, figs. $105-9$.

- (Latona) Faba, Chemnitz, Römer in Martini u. Chemnitz, Conchyl. Cabin., X Bd., 3 Abth., 1869 , p. 88, pl. 2 , figs. $12-13$ and $15-17$.

V. Bertin, Révision d. Donacidées, p. 109, No. 94.

- faba, Chennitz, P. Fischer, Catalogue d. Moll. de l'Indo Chine, p. 241.

- Faba, - Hrdalgo, Fauna malacol. de l. isl. Filipinas, II, p. 169, No. 293,

- tadiata, Spengler, Schröter, Einleit. in d. Conchylienkenntı., III, 1786, p. 104, No. 11, pl. S, fig. 3.

- - Schröter, Girelin, Syst. Nat. ed. XIII, 1790, p. 3266, No. 17.

- radians, Lamarck, Hist. nat. d. anim. s. vert., V, 1818, P. 547, No. 6. - éd. 2, VI, p. 211 , No. 6. Encyclop. méthod. Moll., pl. 261, fig. 7 (non radians, Reeve et Sowerby).

Coast of Lem Ngob (1). South coast of Koh Chang, sand (5). Koh Kahdat, 1 fathom, sand (43). Koh Mak, sandy coast $(1+12 / 2)$.

Islands in the Gulf of Siam (L. MORLET).

Long. $14-26 \mathrm{~mm}$.

Distribution:- Salanga, Madras, Gulf of Manaar, Malabar Coast, Gulf of Oman, Assab (Caramagna), Mauritius, "South Africa" (Sowerny). - Cochin China, Tonkin (banks of Song-kai (Red River)), Hong Kong, Liukiu Isls. (BötTgER), Philippines, Moluccas, Java, New Guinea, Sorong, Port Jackson, New Caledonia, Viti Isls.

Sowerby ${ }^{2}$ considers D. Deshayesii, Dunker (from Lower Guinea), to be a variety of D. faba, Chemn. - D. splendens, Dkx., ${ }^{3}$ is very closely related to the present species.

\section{Fam. Cardiliidae.}

\section{Cardilia inermis, Desh.}

Cardilia inermis, Deshayes, Magazin de Zoologie, 1844 , p. 6 , pl. 100.

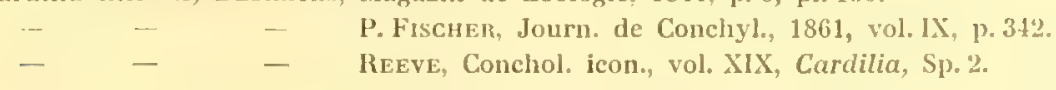

1 DUnker u. Zelebor, Verhand1. d. k. k. zool. botan. Ges. Wien, 1866, p. 916. - G. v. Finavenfetid, Mollusken d. Novara Expedition, p. 15, jl. 2, fig. 27.

"Thesaurus Conchyliorum, III, Donax, pl. IV, figs. 108-9 (and the explanation of plates)

3 Novitates Conchologicae. Meeres Conchyl., p.79, No. 87, pl. 25, fig. 5. 
West of Koln Iiut, 30 fathoms, sand and mud (1/3).

Long. $6 \mathrm{~mm}$., alt. $8 \mathrm{~mm}$.

Distribution:- Philippines (Cuming), Sumatra (Mantis, Deshaves).

\section{Fam. Mesodesmatidae.}

\section{Mesodesma (Atactodea ${ }^{1}$ ) glabrata, Lam.}

Crassalella glabrata, Limanck, Annales du Mus. d'Hist. Nat., VI, 1805, p. 408 (nomen).

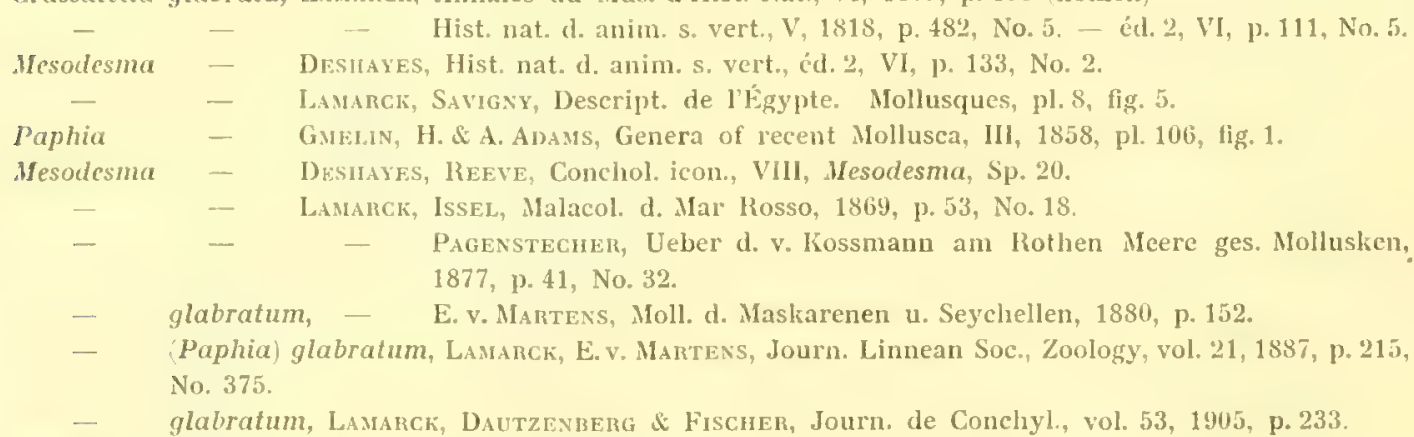

Mactra sulcala, Valengienses, Encyclop. méthod., 1791, pl.257, fig. 3 (nomen).

Mesodesma mitis, DeshaYes, Reeve, Conchol. icon., VIII, Mesodesma, Sp. 29.

- Savignyi, Joussfaume, Deser. a Moll. rec. p. Faurot dans la mer Rouge et le golfe d'Aden, (1888), p. 206, No. 14\%.

South coast of Koh Chang, shallow water, buried in the sand (79). Koh Kahdat, 1 fathom, sand (8). Koh. Mak, sandy coast $(3 / 2)$.

Long. $10-31 \mathrm{~mm}$.

Distribution: - Singapore, Salang, Mergui Isls, Andamans, Ceylon ("Extends from Ceylon throughout the Indian Ocean," Mecylu and Syres), Maldives, Gulf of Aden, Red Sea, Suez, Seychelles, Amirantes, Madagascar, Mascarenes, Mozambique, Querimba Isls. - Philippines (v. Martens), Tonkin, Thursday Isl. (Torres Strait), "Australia" (v. MarTENs).

Mesodesma striala, Chemn., and M. glabrata, Lam., have undoubtedly frequently been confused with each other by several authors; thus, M. striata is recorded by Caramagna and Mörm, ${ }^{3}$ to have been taken from the Red Sea and at Aden; and I believe that also MorLET's ${ }^{\star}$ M. striata, from "Iles du golfe de Siam" unquestionably refers to specimens of $\mathbf{M}$. glabrata, Lam. In addition to this, these two species are very badly characterized and figured. Cukmitz says, e. g. regarding his striata, that "nur allein die Wirbelspitzen sind last vollig glatt," but this is seen very

${ }^{1}$ P. Fischer (Manuel de Conchyl., p. 113) rejects LaMarck's generic name Paphia and adopts Swanson's name Eryx. Dall (Proc. Malacol. Soc. London, 1, p. 213) thinks that this name is not satisfactory as it is "preoccupied in zoology" and makes a new name, viz. Alaclodea.

Proc. Zool. Soc. London, 1891, p. 435.

${ }^{3}$ Catal. conchyl. quae rel. Yoldi, 1I, p. 16, No. 166.

' Journal de Conchyliologie, vol. 37, 1889, p. 172, No. 87. 
indislinctly in his figure; and LAMARCK observes regarding glabrala: "malibus umbonibusque glabratis," but this slight diflerence which is probably intended to be the chief distinguishing point (the striation of the rest of the shell being no doubt almost similar in both the species), is confined to a matter of taste. On examining the figures, e.g. of glabrata by ADAms (loc. cit.) and of striata by REEvE (sp. 10), it will be seen that the sculpture is almost similar, and that the form differs but slightly; but the material of M. glabrata at my disposal shows that the outline varies highly - from a high triangle (long. $27 \mathrm{~mm}$, alt. $23 \mathrm{~mm}$ ) to an oblongovate form (long. $24 \mathrm{~mm}$., alt. $18 \mathrm{~mm}$.). - It is desirable that these two forms should be compared with each other, and especially that striata should be more accurately characterized. In glabrata the regularly-arranged concentric striation begins generally when the shell has reached a height of about $8-12 \mathrm{~mm}$, but it may often be traced before this.

Davila crassula, Desh.

Mesodesma crassula, Deshayes, Proc. Zool. Soc. London, XXII, 1854, p. 336, No. 87.

$\begin{array}{llll} & - & - & \text { ReEve, Conchol. icon., VIII, Mesodesma, Sp. } 26 . \\ \text { Davila } & - & - & \text { H. \& A. Adaws, Genera of rec. Mollusca, pl. 106, fig. } 6 . \\ \text { Mesodesma } & - & - & \text { Hidalgo, Fauna malacol. de I. isl. Filipinas, II, p. 66, fig. } 135 .\end{array}$

Koh Kahdat, 1-5 fathoms, sand (3). On the coast of Koh Kahdat ( $8 / 2)$.

Long. 8-18 mm.

Distribution:- Elphinstone Isl. (Mergui Archip., v. Martens), Philippines.

\section{Ervilia bisculpta, Gould.}

(Pl. IV, Figs. 14-16).

Ervilia bisculpla, Gotud, Proceed. Boston Soc. Nat. Hist., VIII, 1861-62, p. 28. - Otia Conchol., p. 166.

- _- _ Eng. Simpr, Report on the Lamellibranchiata of the Challenger Exped., p. S0. Ervillia - - Pilsbry, Catal. Mar. Moll, Japan, 1895, p. 118.

Ervilia - - Henley, Proc. Linn. Soc. New South Wales, vol. 31, 1906, p. 479, pl. 36, fig. 8. australis, Avgas, Proc. Zool. Soc. London, 1877, p. 175, pl. 26, fig. 21.

incolor, DEsHAYes, MSS. in Brit. Mus.

Corbula isomeros, Hinds, MSS. in Cuming's Collection, Brit. Mus.

Koh Kram, 30 fathoms ("). $)$ N. of Koh Kam, 5 fathoms, gravel (1). Koh Mesan, 15 fathoms; stones (3). Between Kolı Mesan and Cape Liant, 5-9 fathoms. sand (42). W. of Koh Chuen, 5 fathoms, gravel (1). North end of Koh Chang, 1-2 fathoms, old coral blocks (1/2). Koh Kahdat (6). Between Koh Kut and Koh Kahdat, 10 fathoms, shells (1/2). W. of Koh Kut, 15 fathoms, mud (4).

Long. $1 \cdot 5-5 \mathrm{~mm}$.

Distribution:- Singapore (shallow water, Sv. Gav). Durban (Burnup). Philippines, Japan, Mast Head Reef (Queensland), Port Jackson (Sydney), Sandwich Isls.

Angas's figure of $\boldsymbol{E}$. australis (Proc. Zool. Soc. London, 1877) corresponds badly with his diagnosis of the same species, and it is upon EvG. Surtu's authority alone that I give it as a synonym of E. bisculpta. 


\section{Fam. Mactridae. \\ Mactra (Trigonella) achatina, Ch.}

Mactra achalina, Chennitz, Conchyl. Cabin., XI, 1795, p. 218, pl. 200, figs. 1957-58.

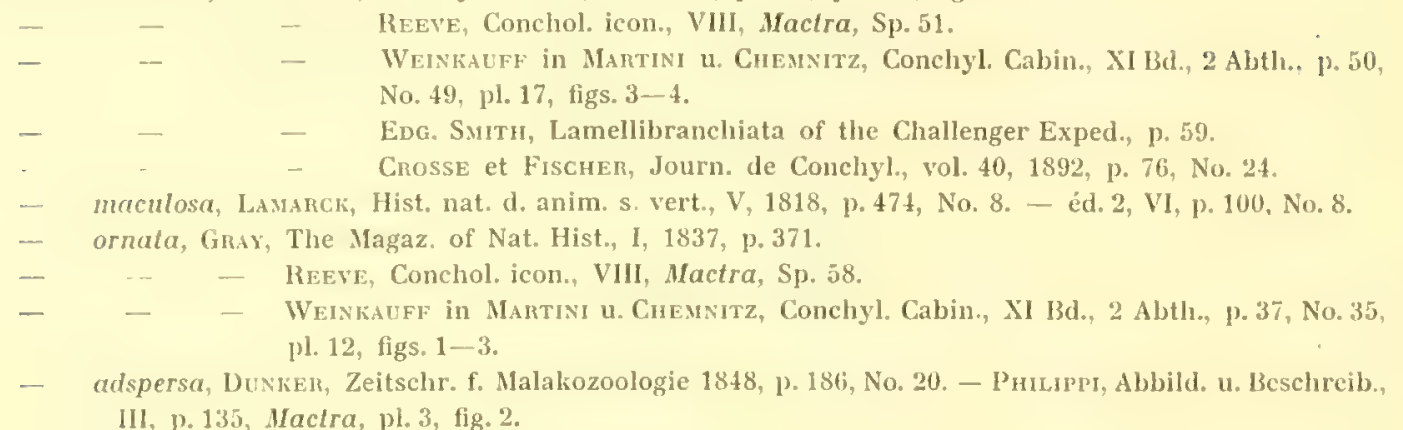

III, p. 135, Mactra, pl.3, fig. 2.

Koh Kahdat (several young individuals).

Gulf of Siam, west coast of Cambodge (PAviE).

D istribution:- Singapore (shallow water, Sv. Gaid), Nicobars, Andamans, 'Tranquebar, Ceylon, Angrias Bank (Melvill and Standex), Persian Gulf, Aden, Red Sea, Suez, "South Africa" (Sowerry). - Philippines, China, Japan, Torres Strait, Admirally Isl.

\section{Mactra (Trigonella) maculata, Ch.}

Ifactra maculala, Cusmatz, Conchyl. Cabin., VI, 1782, p. 217, pl.21, figs. 208-9.

- ReEve, Conchol. icon., VIII. Mactra, Sp. 56.

Weinkauff in Martini u. Chemnitz, Conchyl. Cabin., XI Bd., 2Abth., p. 10, No. 7 , pl. 3 , figs. $4-5$; pl. 16 . figs. $5-6$.

- Hrdalgo, Fauna malacol. de 1. isl. Filipinas, II, p. 48, No. 100.
- squalida, Lamarck, Hist. nat. d. anim. s. vert., V, 1818, p. 478, No.26. - éd. 2, VI, p. 105, No. 26.

- - - Hanler, Catal. of rec. biv. shells, p. 31, pl. 11, fig. 30 .

-- setosa, Quor, Voyage de I'Astrolabe, Zoologie, 111, 1833, p. 519, pl. 83, figs. 3-4.

Reevei, Desnayes, Proc. Zool. Soc. London, XXI, 1853, p. 15, No.3.

- MeEve, Conchol. icon., VIII, Mactra, Sp. 85.

Weinkafff in Marenir u. Chemisz, Conchyl. Cabin., XI Bd., 2 Abth., p. 66, No. 67, pl. 23 , fig. 4 .

Morler, Journ. de Conchyl., vol. 37, 1889, p. 172, No. 88.

Islands in the Gulf of Siam (L. MonLET).

The Danish Experition to Siam collected no specimens of this species.

Distribution:- Nicobars. - Philippines, Loo Choo Isls. (Yaeyama), Amboina, Sorong, Sulu Isis., Mast Head Reef (Queensland), New Caledonia, Vanikoro Isl., Pelew Isls.

\section{Mactra (Trigonella) cuneata, Ch.}

(I). IV, Figs. 17-19).

Hatela cuneata, Chismiry, Conchyl. Cabin., VI, 1782, p. 221, pl. 22, fig. 215. Gimeln, Syst. Nat., ed. XIII, 1790, p. 3260, No. 19.

REEve, Conchol. icon., VIII, 1854, Mactra, Sp. 109. 
Mactra cuneala, Chemnitz, WerniatfFe in Mantrin u. Chemnitz, Conchyl. Cabill, Xi Bd., 2 Abth., p.13, No. 10, pl. 4 , figs. $3-4$.

- purpurea, SPEngler, Skrivter af Naturhistorie-Selskabet, V Bd., 22 Hefte, 1802, P. 111, No. 17.

- corbiculoides, DeshaYes, Proc. Zool. Soc. London, XXII, 1854, p. 62, No. 4.

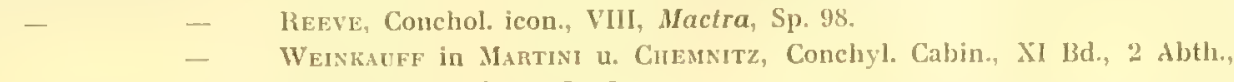
p. 91 , No. 97 , pl. 31 , fig. 3 .

The strand off the Mangrove at the station on Koh Chang, shallow water (3). The strand of Koh Kahdat (5/2).

Long. 4-15 $\mathrm{mm}$.

Distribution:- Nicobars, Ceylon, and Gulf of Manar.

The small individuals from the Gulf of Siam agree fairly well with ReEve's cuneata, which is probably founded on not full-grown individuals, at any rate SPEngler's original specimens of $M$. purpurea are considerably larger (long. $31 \mathrm{~mm}$., alt. $27.5 \mathrm{~mm}$., crass. $18 \mathrm{~mm}$.) and are thick-valved. I cannot find any difference between the latter and DESHAYEs's corbiculoides, which, judging from the figure and description, agrees in all points with it; therefore, I have not hesitated in giving them as synonyms. Setting aside the outline, the following features are characteristic of $M$. cuneata, Ch.:-- the intense dark-lilac colour of the interior of the valves (the lateral teeth are pale), the pale lilac and ash-gray colour of the exterior of the valves, and the beautiful regular striation of the lunule and area. Besides this typical form there are also individuals which are entirely white, without a trace of colour (CHEmitz has already mentioned such specimens), several specimens of this variety were taken at Koh Kahdat. I entirely agree with WEINKAufF when he writes (loc. cit. p. 29) that M. Iurida, Phil., is very near to $M$. corbiculoides, Desh.; I think that lurida can scarcely be separated from M. cuneata, Ch. (= corbiculoides, Desh.), as a good species.

Mactra (Trigonella) Luzonica, Desh.

Mactra Luzonica, Deshares, Proc. Zool. Soc. London, 1854, p. 64, No. 12.

- - _ ReEve, Conchol. icon., VIII, Mactra, Sp. 81.

Weinhauff in Martinı u. Chemnitz, Conchyl. Cabin., XI Bd., '2 Abth., 1884, p. 49 , No. 48, pl. 17 , figs. $1-2$.

- - _ Hibalgo, Fauna malacol. de 1. isl. Filipinas, II, 1903, p. 50, No. 102.

Koh Kahdat $(1 / 2)$.

Long. $14 \mathrm{~mm}$, alt. $9.5 \mathrm{~mm}$.

Distribution:- Arakan Coast (Blanford), Calcutla (Lady Herschel), Madras (Henderson), Ceylon (Herdman), Bombay (Melvill \& Abercromie), the coast of Continental India (from Karachi to Panjim, Mervill \& Standen). - Philippines (Cuming).

Though the small valve which is at hand is somewhat worn, l have no doubt as to the correctness of the determination. G. F. Angas (Proc. Zool. Soc. London, 1867, p. 916. - J.C. Cox, Exchange List of Land and Marine Shells from Australia, 
1868, p. 24, No. 344) records M. Luzonica, Desh., from Port Jackson and Botany Bay, but Eng. Smith ${ }^{1}$ thinks that the specimens from these localities are identical with M. pusilla, A. Ad.

\section{Mactra (Mactrinula) angulifera, Desh.}

Mactra angulifera, Desnayes, Proc. Zool. Soc. London, XXII, 1854, p. 70, No. 37.

- - - - Reve, Conchol. icon., VIII, Mactra, Sp. 83.

- - _ - Weinkauff in Martini u. Chemsitz, Conchy]. Cabin., Xil Bd,, 2 Abth., p.83. No. 87, pl. 28, fig. 5.

Mactrinula - $\quad$ EDg. SMTн in Rep. Zool. Collect. made during the Voyage of H. M. S. "Alert," 1884, p. 101.

Hidalgo, Fauna malacol. de 1. isl. Filipin.. II, p. 56, No. 115.

Maclra ovalina non Lamarck', ReEve, Conchol. icon., VIII, Mactra, Sp. 66.

South of Koh Chuen, 30 fathoms, shells (1/2). North of Koh Kahdat, 4-5 fathoms, coarse sand (1). West of Koln Kut, 30 fathoms, sand and mud ( $(2 / 3)$.

Long. $7-31 \mathrm{~mm}$.

Distribution:- Singapore (shallow water, Sv.Gan), Mergui Archip. (E. v. Martens), Persian Gulf (E. v. Mantens). - Philippines (Cumng).

EDG. Surtu ${ }^{2}$ is of opinion that M. angulifera, Desh., is not specifically distincl from $M$. depressa, Spengler (Reeve), but in this he is probably mistaken. I have on Pl. IV, Figs. 20-23 given figures of M. depressa, Spgl., drawn from Spenguen's original specimens in the Zoological Museum of the University of Copenhagen. On comparing these figures with ReEve's figure of $M$. angulifera, Desh., one can soon be convinced that they are two distinct species (the valves of $\boldsymbol{M}$. depressa are much thicker and more solid than those of M. angulifera). REEvE's description and figure of Spengler's depressa (Sp.67) agree well with the original specimen. It is quite natural that EDg. SMTH should doubt whether REEVE has correctly apprehended Spengler's form, as Spengler's description is not good, and his statement that Guinea is the locality is undoubtedly wrong. M. ovalina, Lam., has been greatly misapprehended by various authors; WeINKAUFF ${ }^{3}$ records it (= falcata, Gould) from Puget Sound; TATE and MAY record it (= depressa, Reeve) from Tasmania; G. B. Sowenizy records it (= depressa, Spgl.) from Durban in South Africa; n'Onmany" (= M. pragilis, Ch.) from Cuba, Brazil, and Patagonia; etc. It is fairly certain that these authors have had quite dilferent species for investigation.

1 leport on the Lamellibranchiata of the Challenger Expedition, p. 61.

2 Report on the Lamellibranchiata of the Challenger Lxpedition, p. 57.

3 Mantint u. Cheminz, Conchyl. Cabin., XI Bd., 2 Abth., p. 69, No. 70.

' Proc. Linnean Society of New South Wales, 1901, p. 423.

5 Marine Shells of South Africa, Appendix, 1897, p. 22. EvG. Smitu also recorcls it (Journ. of Malacology, 1904, p. 25) from Port Alfred, Cape Colony.

Gollusques de l'ile de Cuba, 1853, 11, p. 222. List of the Shells of South America in the collect. of the I3ritish Muscum, 1851, 1.56, No. 489. 


\section{Mactra (Mactrinula) Reevesi, Gray.}

Mactra Reevesii, Gray, The Magazine of Natural History, I. 1837, p. 372.

- - - ReEve, Conchol, icon., VIII, Mactra, Sp. 92.

- - - Weinfiauff in Mantini u. Chemitz, Conchyl. Cabilı, XI Bd., 2 Abth., p. 82, No. 85, pl. 28 , fig. 2.

Mactrinula Reevesii, Gray, Edg. Sмiти, Annals and Mag. Nat. Hist., 7 Ser., vol. 14, 1904, p. 9.

East of Koh Chuen, 9-10 fathoms, shells (1/2). South of Koh Samit, 14-18 fathoms (1).

Long. $40 \mathrm{~mm}$., alt. $25 \mathrm{~mm}$., crass. $13 \mathrm{~mm}$.

Distribution: - Malacca Strait. Off Chedubar (Aracan coast). - China.

Lutraria impar, Desh.

Lutraria impar, Deshayes, Proc. Zool. Soc. London, XXII, 1854, p. 70, No. 38. ReEve, Conchol, icon., VIII, Lutraria, Sp. 10.

West of Koh Kong, 10-15 fathoms (1/2).

Long. $69 \mathrm{~mm}$, alt. $26 \mathrm{~mm}$.

Distribution:- Moreton Bay, Australia (Strange).

Of this characteristic species only one dead left valve, withoul epidermis, is found in the collections of the Danish Expedition to Siam.

Lutraria maxima, Jonas.

Lutraria maxima, Joxas, Zeitschr. f. Malakozoologie, 1844, p. 34. - Molluskologische Beiträge (Abhandl. aus d. Gebiete d. Naturwiss., I, Hamburg 1846), p. 110, No. 2, pl. 7, fig. 1 (non Lutraria maxima, MiddexvorfF, Malacozoologia llossica, III, p. 582).

ReEve, Conchol. icon., VIII, Lutraria, Sp. 11.

$-\quad$ Lischí, Japan. Meeres-Conchyl., 1, 1869, p. 138.
-
Dunker, Index molluscor. mar. Japon., 1852, p. 185.

The sound of Kolr Chang, 5 fathoms, soft clay (1/2).

Long. $72 \mathrm{~mm}$.

Distribution:- China, Japan (Nagasaki).

Lutraria curta, Desh.

Lutraria curta, Deshayes, Proc. Zool. Soc. London, 1854, p. 71, No. 42.

- ReEve, Conchol. icon., VIII, 1854, Lutraria, Sp. 5.

- - Hoalgo, Fauna malacol. de las isl. Filipinas, II, 1903, p. 59, No. 120.

Between Koh Rin and Cliff Rock, 15 fathoms (1/2).

Distribution: - Aden (Shopland). - Philippines (Reeve).

Only a small fragment of the left valve of a young individual has come to hand from the above locality, so the determination is somewhat uncertain.

Raëta pulchella, Ad, and Reeve.

(Pl. IV, Fig. 24).

Poromya pulchella, Adaus \& Kreve, Zoology of the voyage of H. M. S. Samarang, Mollusca, 1848, p. 83, pl. 23, fig. 1.

Raeta - - _ EDG. Simtr, Lamellibranchiata of the Challenger Expedit., p. 56. 
Raeta pulchella, Adams \& ReEve, Hidalgo, Fauna malacol. de I. isl. Filipinas, II, p. 58, No. 119.

Mactra rostralis, Deshayes, Proc. Zool. Soc. London, XXII, 1854, p. 69, No. 32.

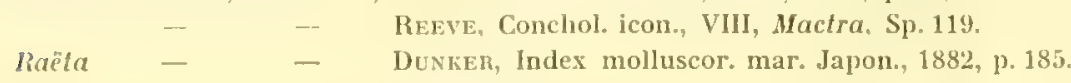

The sound of Koh Chang, 5 fathoms, soft clay $(1 / 2)$.

Long. $25 \mathrm{~mm}$., alt. $17 \mathrm{~mm}$.

Distribution: - Borneo, Philippines, China, Japan (Yokolnama).

The specimen from Koh Chang is larger than the individuals which have hitherto been described (long. $20 \mathrm{~mm}$., alt. $14 \mathrm{~mm}$.); it bears a very strong resemblance to the form taken by R. Sturany ${ }^{1}$ at Ras Mallap in the Gulf of Suez in 50 fathoms, which he names Raelta bracheon; how far this species is synonymous with R. pulchella, Ad. and Reeve, I am not prepared to say. Unfortunately, my material consists only of a solitary, broken, left valve, of which I give a figure for future comparison.

Raëta anatinoides, Reeve.

Mactra Anatinoides, IRFEve, Conchol, icon., VIIr, 185t, Mactra, Sp. 123.

The sound of Koh Chang, 3-5 fathoms, soft clay (7/2, partially fragments) N. of Koh Kong, 8 fathoms, mud $(* / 3)$.

Long. 5-14 mm. (long. $14 \mathrm{~mm}$., alt. $12 \mathrm{~mm}$.).

Distribution unknown.

By comparisons in the British Museum, I have convinced myself that the specimens from the Gulf of Siam are really identical with $R$. anatinoides, Reeve, and not with $R$. pellicula, Desh., which, however, comes near to $R$. anatinoides, Reeve.

\section{Standella pellucida, Ch.}

Mactra pellucida, Cufmsitz, Conchyl. Cabin., VI, 1782, p. 235, pl.24, fig. 234.

- $\quad$ - Spexgler, Skrivter af Naturhistorie-Selskabet, V B3d., 2 H., 1802, 13. 123, No. 29. REEvE, Conchol. icon., VIII, Mactra, Sp. 118.

Weinkauff in Martini u. Chemnitz, Conchyl. Cabin., XI lid., 2 Abth., p. 17, No. 14 , pl. 5 , fig. 1.

Standella - - Hidalgo, Fauna malacol. de 1. isl. Filipin., II, p. 57, No. 117.

- Merope; pellucida, Chenntz, Melvill \& Standen, Proc. Zool. Soc. London, 1906, p. 828.

Mactra depressa, Lamarck, Hist. nat. d. anim. s. vert., V, 1818, 1.479, No.29. - éd. 2, VI, 1. 106, No. 29. Encyclop. méthod., 1I, 1830, p. 398.

Coast of Lem Ngob $(1+\% / 2)$. The strand off the Mangrove at the station on Koh Chang, quite shallow water (6).

Long. $7-48 \mathrm{~mm}$.

Distribution:- Bombay, extending southwards to Ratnagiri (Mervill \& Standen). - Philippines.

Melvill and Abercrombie write that dead specimens of the present species are common at Bombay; the two right valves from Lem Ngob are also from dead individuals, all the other individuals, which are small, were taken alive.

1 R. Stunaxy, Lamellibranchiata d. Kothen Meeres. Wien 1899, p. 12, No. 10, pl. 3, figs. 1-6. 


\section{Eastonia (Merope) Nicobarica, Gmel.}

Mactra rngosa Indiae orientalis, Chemsitz, Conchyl. Cabin., VI, 1782, p. 238, pl. 24, fig. 237.

- nicobarica, GMELIN, Syst. Nat. ed. XIII, 1790, p. 3261, No. 21.

Anatinella Vicobarica, Guelin, Tennant, Natural History of Ceylon, 1861, p. 389.

Lutraria Merope) Nicobarica, Gireris, v. ManTens, Journ. Linnean Society, Zoology, 1887, vol. 21, p. 217. pl. 16 , fig. 7.

- - nicobarica, Gmeris, Thunstox, Rámésvaram Island and Fauna of the Gulf of Manaar. 2 ed., 1895, p. 128.

Mactra Aegyptiaca, Chemnrtz, Conchyl, Cabin., XI, 1795, p. 218, pl. 200, fìgs. 1955-56.

Lutraria Egyptiaca, Gnay, Hanlex, Catalogue of rec. biv. sleells, p. 26, pl. 6, fig. 34.

Iactra Egyptiaca, Chemsitz, ReEve, Conchol. icon., VIII, 1854, Mactra, Sp. 112.

Lutraria Aegiptiaca, - Issel, Malacologia d. Mar Rosso, 1869, p. 52.

Metope Egyptiaca, Gray, AxGas, Proc. Zool. Soc. London, 1871, p. 100.

-- Aegyptiaca, Chesnitz, Dunier, Index molluscor. mar. Japon., 1882, p. 184.

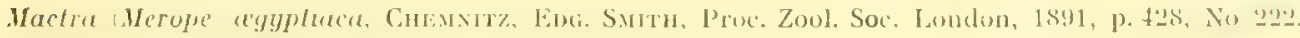

Eastonia - aegyptiaca, - PILsiry, Marine Mollusks of Japan, 1895, p. 120.

Slandella Egypliaca, Chemnitz, Shopland, Proc. Malacol. Soc. London, V, p. 177.

Mactra reticulata, Spenglek, Skrivter af Naturhistorie Selskabet, V Bd., 2 Hefte, 180, p. 119.

Lulraria Chemnitzii, PhuppI, Zeitschr. f. Malakozool., 1849, p. 26, No. 99.

Between Koh Riot and Koh Mesan, 3-5 fathoms, sand (1/2). Koh Kahdat, 1 fathom, sand $(1 / 2)$.

Long. $18-43 \mathrm{~mm}$.

Distribution:- Singapore (shallow water, Sv. GAD), Mergui Archip., Nicobars, Ceylon, Karachi, Aden, Red Sea (Chennitz, Isser, Forskål (Mus. Univ. Hafn.), Sturany). - Java, Panay Isl. (Mus. Univ. Hafn.), Japan, Liukiu Isls., Lake Macquarie (New South Wales).

As the original specimens of Chemsitz's "Mactra rugosa Indiae orientalis" and Mactra Aegyptiaca have been at my disposal, it has been possible for me to verify the reciprocal relation of these forms. Mactra rugosa Indiae orientalis has been described by Chemitz from a specimen in Spengler's collection, and was afterwards named Mactra reticulata by the latter. The figure given by Cnemnitz is very bad, but ReEve's figure, Sp.112, is an excellent illustration of the species, both as regards its form and its sculpture; the reticulata-form thus indicates the individuals with pointed posterior end and coarser radiating ribs, and the interstices between the ribs 2-3 times the width of the ribs. The other species M. Aegypliaca has been figured fairly well by Chemnitz; it comprises the forms with oval shells, and finer, more closely set radiating ribs; but between these two extremes there is an extensive series of intermediate forms, which I have before me, and which distinctly show that it is same species which varies. I have also at hand that small characteristic form which ED. v. Martens describes and figures from "King Island, mud-bank exposed at spring-tide;" my specimen was taken at Singapore in shallow water, it is only a thin-valved, littoral, local form of E. Nicobarica Gun., ornamented with rather slight and delicate ribs.

I). K. D. Videnak. Selsk. Slir., 7. Rakke, natursidensk. of mathem. Afu. V. 3. 


\section{Caecella Cumingiana, Desh.}

Cecella Cumingiana, Drshayes, Proc. Zool. Soc. London, XXIl, 1854, p. 334, No. 78.

- - ‥ Hidalgo, Fauna nalacolog. d. 1. isl. Filipinas, II, p. 60, No. 123.

Koh Chang (14), Coast of Koh Chang (1).

Long. $10-26 \mathrm{~mm}$.

Distribution:- Philippines.

I have at my disposal some specimens of $C$. Cumingiana, Desh., from the Philippines which were contributed by Cuning himself; they are somewhat larger than the specimens from the Gulf of Siam, but otherwise exactly correspond with them. The epidermis in the small individuals (measuring as much as $23 \mathrm{~mm}$. in length) is pale yellow, while in older individuals it is brownish. It will undoubtedly be proved in the future that the series of species established by Deshayes of the genus Caecella, can be considerably reduced.

\section{Fam. Veneridae. Cytherea (Meretrix) meretrix L.}

Tenus Meretrix, Linné, Syst. Nat., ed. X, 1758, p. 686, No. 102. - ed. XII, p. 1132, No. 127. - Mus. Ludovicre Ulricæ reg., p. 501 , No. 60.

Cytherea meretrix, LiNnÉ, LISchke, Japanische Meeres-Conchylien, I, pl. 122-26.

Meretrix - - Dautzenieng et Fischer, Journ. de Conchyl., vol.53, 1905, p. 216.

Venus lusoria, Chemnitz, Conchyl. Cabin., VI, 1782, p. 337, pl. 32, fig. 340.

Meretrix - - MöMer, Monogr. d. Molluskengatt. Venus, I, p. 30, pI. 12, fig. 1; pl. XI, figs. 1 - 2.

Cylherea petechialis, Lamarck, Hist. nat. d. anim. s. vert., V, 1818, p. 561, No. 2. - éd. 2 , VI, p. 295, No. 2. Merelrix _- Röner, Monogr. d. Molluskengatt. Venus, I, p. 29, pl.9, fig. 1.

Venus zonaria, - Hist. nat. d. anim. s. vert., V, 1818, p. 562, No.5. - éd. 2, VI, p. 299 , No. 5.

- impudica, - Hist. nat. d. anim. s. vert., V, 1818, p.561, No. 3. - éd. 2, p. 299 , No. 3.

North coast of Koh Chang (1).

Long. $51 \mathrm{~mm}$.

Islands in the Gulf of Siam (M. petechialis, Lam. - L. MonteT). "Siam" (M. impudica, Lam., M. zonaria, Lam. - E. v. Martens).

Distribution: - Singapore, Salang (Malacea), Nicobars, Ceylon, Bombay, Aden. - Annam, Tonkin, Clina, Formosa, Japan, Liukiu Isls., Philippines, Borneo, Java, Timor, Moluccas. ("Mazatlan," CARpenter; without doubt the determination is erroneous).

The specimen from Koh Chang belongs to the form zonaria, Lam. The many different species which have been established by LAMARCK and other authors on the basis of the present species, have for a long time rendered its determination difficult, and Liscrike (loc. cit.) was the first to demonstrate, and that correctly, that all these forms belong to the same species. In spite of this, many later authors lnave persisted in maintaining the varieties as species, a view which is quite untenable when larger series and specimens in various ages are at hand for investigation. 
Hidalgo (Obras malacológicas, I, Tom. 2, 1903, p. 182) has enumerated 10 different colour-variations of Cyth. meretrix from the Philippines. DAUTzENBERG and H. FISCHER (Journ. de Conchyl., vol. 53, 1905, pp. 216-20) enumerate the synonyms of this well-known species, which form a long list.

Cytherea (Meretrix) 1yrata, Sow.

Cylhercia lyrata, Sowerbx, Thesaurus Conchyl, II, 1855, p.621, pl. 129, fig.61.

Cytherea - - Reveve, Conchol. icon., XIV, Cylherea, Sp. 13.

- (Meretrix) lyrata, Sowerby, Römer, Monogr. d. Moll. Venus, I, p. 36, No. 11, pl. 11, fig. 3.

Meretrix lyrata, Sowentr, MorLet, Journ. de Conchyl., vol. 37, 1889, p. 168, No. 59.

Fischer, Catalogue de Moll. de l'Indo-Chine, p. 233.

Islands in the Gulf of Siam. (MORLET, loc. cit.).

Distribution: - Cambodge, Cochin China, Tonkin, Philippines,

The present large species, strangely enough, was not collected by the Danish expedition.

\section{Cytherea (Caryatis) hebraea, Lam.}

Cylherea hebroca, LaManck, Hist. nat. d. anim. s. vert., V, 1818, p. 568, No.30. - cd. 2, VI, 1835, p. 308, No. 30.

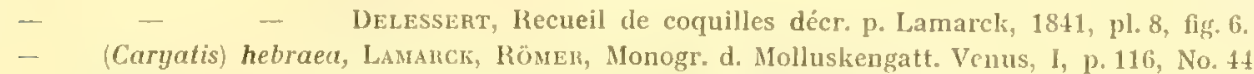

Circe Hebrcea, Lamarck, Reeve, Conchol. icon., vol. 14, 1863, Circe, Sp. 34.

- hebraa, - Monlet, Journ. de Conchyl., vol.37, 1889, p. 169, No.64.

Cytherea (Caryatis) hebraa, LAmarck, EDG. A. SMitr, Lamellibranchiata of the Challenger Expedition, 1885, p. 138.

Islands in the Gulf of Siam (MORLET, loc. cit.).

It is with doubt that I refer a small ( $8 \mathrm{~mm}$.) single valve from the coast of

Koh Kahdat to the present species.

Distribution: - Ceylon, Persian Gulf, Aden, Red Sea, Seychelles, Natal. Philippines, Torres Strait, New South Wales.

It is doubtful whether all the authors who have recorded the present species from the above-mentioned localities have had the true Cyth. hebraea, Lam., before them. It is recorded by several authors (e. g. H. KREBs, O. Mörch, C. T. Simison, W. H. DALL, etc.) from the West Indies, but these records are due to its having been confounded with Cyth. varians, Hanl.

\section{Cytherea (Caryatis) affinis, Gmel. var. inflata, Sow.}

Cytherce inflata, Soweriy jun., Thesaurus Conchyl., II, 1855, p. 637, pl. 133, figs. $12 \overline{7}-28$.

Dione - - - REeve, Conchol. icon., XIV, Dione, Sp. 37.

- - - _ - Deshaxes, Catalogue of the Conchifera in Irit. Mus., 1853, p. 65, No. 28.

Cytherea affinis, Gmelin var, inflata, Sowerby, Pfeiffer in Martiny u. Chemnitz, Conchyl. Cabin., XI, 1 Abth., pp. $24-25$.

(Caryatis) affinis, Gmeun var. inflata, Sow., Röser, Monogr. d. Molluskengatt. Venus, I, p. 105. pl. 33 , figs. $6-7$.

Callista inflata, Sowerny, Dunker, Index moll. mar. Jajon., 1882, p. 201.

Pitaria - - HedLey, Proc. Linu. Soc. New Soutl Wales, vol. 31, 1906, p. 466. 
Between Kol Mesan and Koh Chuen, 25--38 fathoms, stones and shells (1/2). S. of Koh Chuen, 30 fathoms, shells (1/2). Koh Mak, sandy coast (1/2). S. of Koh Mak, 5-6 fathoms $(1 / 2)$. N. of Koh Kahdat, 4-5 fathoms, sand (1). Koh Kahdat, 1 lathom, sand $(3 / 2)$.

Long. 8-34 mm.

D istribution:- Nicobars, Andamans, Ceylon, Mauritius, Reunion, Rodriguez. - Philippines, Japan, Moluccas, 'Torres Strait, Mast Head Reef (Queensland), Port Curtis (Australia), Lifu.

\section{Cytherea (Caryatis) striata, Gray.}

Chione striata, Gray, The Analyst, VIII, 1838, p. 306.

Cythercea citrind (non Lamarck), Sowrrbs, Thesaurus Conchyl., II, p. 636, pl. 132, figs. 117-18.

Dione striala, Gray, ReEve, Conchol. icon., XIV, Dione, Sp. 44.

Cylherea (Caryatis) citrina, Rösen, Monogr. d. Molluskengatt. Venus, 1, p. 100, pl. 27, fig.2.

Callista citrina, Rochebnune, Bull. de la Soc. Philomat. de Paris 1881, (Reprint, p. 15, No.48).

Merelrix (Pitar) cilrina, Fischen, Catalogue d. Moll. de l'Indo-Chine, p. 233.

North coast of Koh Chang $(1 / 2)$.

Long. $36 \mathrm{~mm}$.

D istribution: - Poulo Condor, Philippines, Formosa, Sulu Isls., Kei Bandan, Jobi Isl. (Geelwinck Bay).

C. striata, Gray, has always been referred to C.citrina, Lam., but sufficient proof that it is not that species appears to me to be given by LaMarck's diagnesis ("Lesta coldata-trigona") and by Delessent's figure (Pl. 8, Fig. 8) of Lamarck's original specimen. Hrdalgo ${ }^{1}$ has arrived at the same conclusion with regard to the specimens from the Plilippines. Hanıer's C. striata, Gray?" from the "River Gambia" is not Gray's species of that name, but is identical with C. citrina, Lam. 'The individual from the Gulf of Siam which I have before me exactly agrees with Römer's description and figure (loc. cit.) of C. citrina $(=C$. striata, Gray). The true C. cilrina, Lam., occurs around Australia, and is easily distinguished from striata by its more triangular form and by its posterior end being considerably more pointed as compared with the more truncated form of striala.

\section{Cytherea (Caryatis) minuta, Koch.}

(Pl. 1V, Figs. 25-27).

Cylherea minula, Косн, Pнтирг, Abbila. u. Beschreib. neuer od. wenig gekannt. Conchylien., I, 1845, 1). 22 $(200)$, Cylherea, pl. 33, fig. 8.

(Caryatis) minuta, Koch, Römen, Monogr. d. Molluskengatt. Venus, I, p. 124, pl. 33, fìg. 1.

Dione minula, Koch, Desiayes, Catalogue of the Conchifera in Brit. Mus., I, p. 73, No. 58.

Koh Kram, 30 fathoms (1). Koh Chuen, 10-15 fathoms (3/2). W. of Koh Chuen, soft clay and mud ( $10 / 2)$. W. of Kol Chang, 30 fathoms $(3 / 2)$. W. of Koh Chang, 20 fathoms, mud (3). The strand off the mangrove at the station on Koh

1 Orzas malacológicas, I, Tom. 2, 1903, p. 198.

"Sownur, Thesaurus Concliyl., I, p. 6i37, pl. 132, tig. 113. 
Chang (1/2). Between Koh Chuen and Koh Chang, 15 lathoms, mud $(1 / 2)$. Between Koh Kahdat and Koln Kut, 6-10 fathoms, clay mixed with sand (6). W. of Koh Kut, 15 fathoms, mud (2). W. of Koh Kut, 30 fathoms, sand and mud $\left({ }^{14 / 2}\right)$. S. of Koh Kut, 17-20 fathoms, mud (1). S. of Koh Kahdat, 8-10 fathoms, mud (1/3). E. of Koh Mak, 20 fathoms, mud (4). W. of Koh Kut, 15 fathoms, mud (1).

Long. $3-16 \mathrm{~mm}$.

Distribution:- Mergui Archip. (E. V. Martens).

The figure by Rōmer (loc. cit.) is not good, therefore I have figured some of the specimens from the Gulf of Siam. E. v. Martens was the first (1887) to give a locality for this species. C.chordata, Römer, is perhaps the same species.

\section{Cytherea (Caryatis) Yerburyi, Smith.}

Cytherea (Caryatis) Yerburyi, EdG. Smitr, Proc. Zool. Soc, London, 1891, p. 423, No. 192.

Dione erubescens, ReEvi (non Dunkei), Conchol. icon., XIV, 1863, Dione, Sp. 54.

Koh Kahdat, 1-5 fathoms, sand (1). W. of Kol Kut, 15 fathoms, mud (1). W. of Koh Kut, 30 fathoms, sand and mud (2/2).

Long. $10-14 \mathrm{~mm}$.

Distribution: - Ceylon (ReEve), Aden (Brit. Mus.) - Japan (Brit. Mus.), Queensland (Brazier).

The specimens from the Gulf of Siam are covered with a very thin, viscous epidermis, to which grains of sand, etc, are found attached.

\section{Cytherea (Caryatis) Deshayesi, Pfr.}

Cytherea Deshayesi, Preiffen, Martini u. Chemnitz, Conchyl. Cabin., XI Bd., 1 Abth., 1869, p. 7t, No. 57, pl. 30, fig. 9.

Dione crocea, Deshares, Proc. Zool. Soc. London, 1853, p. 2, No. 5. - Catal. Conchif. 13rit. Mus., I, 1853 , p. 66, No. 34 (non Cyth. crocea, Grar).

ReEve, Conchol. icon., XIV, 1864, Dione, Sp. 53.

Caryatis crocea, Deshayes, Römen, Monographie d. Molluskengatt. Venus, I, p. 99, No. 23. p.27, fig. 1.

Specimens from Suracha, Siam (J.H. Ponsonby), are to be found in the British Museum under the name of Callocardia Deshayesi, Pfr. var.

Distribution:- Singapore (Miss Archer, Brit. Mus.). - Philippines.

Cytherea (Caryatis) isocardia, Sow.

Cylherea (Caryatis) isocardia, Sowerny, Proc. Zool. Soc. London, 1888, p.213.

Edg. Smith, Proc. Malacol. Soc. London, IV, p. 81.

Callocardia guttala, A. Adsus, Annals \& Magaz. Nat. Hist., ser. 3, 186t, XIII, p. 307 (non Callista gultala, ROMER?.

EvG. Smiti, Rep. of the Lamellibranchiata of the Challenger Exped., P. 156.

W. of Koh Kut, 15 fathoms, mud (1/2).

Long. $26 \mathrm{~mm}$., alt. $22 \mathrm{~mm}$, crass. $20 \mathrm{~mm}$.

Distribution:- Isl. af Quelpart, south of the Korea (ADAms).

Though the shell which I have before me, from the Gulf of Siam, differs somewhat in form from C. isocardia, Sow. I can scarcely be wrong in referring it to this species. 
Note. It is almost certainly due to erroneous determination when L. MonurT (.Journ. de Conchyl., vol.37, 1889, p. 169, No.61) records Tivela bicolor, Gray, from the islands in the Gulf of Siam; this species has previously been taken only at Senegal.

\section{Circe scripta L.}

V'cnus scripla, LINNé, Syst. Nat. ed. X, 1758, p. 689, No. 121. - ed. XII, p. 1135, No. 145. - Mus. Ludov. Ulr. reg., p. 507, No. 73.

Circe - - Sowrerry, Thesaurus Conchyl., II, p. 651, No. 7. pl. 139, ligs. 38-43.

- - - REEY', Conchol. icon., XIV, Circe, Sp. 1, fig. 1; pl. 2, fig. 5 (C. fulgurata), fig. 6 (C. peronula), pl.3, fig. 11 (C. sugillata).

Cylherea scripla, Lixwé, Martixi u. Chesinitz, Conchyl. Cabin., XI, 1 Alth., p. 54 , pl. 20, figs. 1-4.

Circe - - RöMer, Monogr. d. Molluskengatt. Venus, I, p. 193, pl. 52, fig. 1; pl.59, figgs.3-4.

- Morlet, Journ. de Conchyl., vol. 37, 1889, p. 169, No. 65.

Many specimens were taken around Koh Kahdat and Koh Kut, in $1-15$ fathoms, mud, clay mixed with sand, and sand.

Long. 7-51 $\mathrm{mm}$.

Islands in the Gulf of Siam (MorLET).

Distribution: - Singapore, Mergui Archip., Nicobars, Ceylon, Gulf of Manaar, Mulaku Atoll, Mekran Coast, Persian Gulf, Red Sea, Aden, Suez, Seychelles, Coromandel. - Philippines, China, Japan, Moluccas, Flores Isl., Aru Isl., Torres Strait, Port Jackson (N. S. Wales).

Note. Many specimens of Circe undatina, Lam., have been taken at Singapore in shallow water by Mr. Sv. GAD.

\section{Circe sulcata, Gray.}

Circe sulcala, Gins; The Analyst, VIII, 1838 , p. 307.

- - - Kömer, Malakozool. Blätter, X, 1863, p. 11, No. 16.

- ReEvi, Conchol. icon., XIV, Circe, Sp. 16.

- - Römer, Monogr. d. Molkuskengatt. Venus, I, p. 210 , No. 16, pl. 57. liқ̌. 2. Eng. SMrth, Lamellibranchiata of the Challenger Exped., 1885, p. 142.

Artemis, Desmares, Catalogue of the Conchifera of British Muscum, 1853, p. 86, No. 12. REEve, Conchol. icon., XIV, Circe, Sp. 15.

Melculfei, - Proc. Zool. Soc. London, XXI, 1853, p. 7, No. 28.

Cylherea erythraca, Jonas, Zeitschr. f. Malakozool., 1845, p. 65.

- PHilippl, Abbild., III, 1851, p. 71, pl. 9, fig. 2.

Circe pecta, Röмгı, Malakozoolog. 13lätter, VII, 1860, p. 155.

Cytherea paeta, Röner, Martini u. Chemsitz, Conchyl. Cabin., XI, 1 Abth., p. 59, pl. 22, figs. $6-7$. plebeja, Hanlex, Proc. Zool. Soc. London, XII, 1844, p. 109.

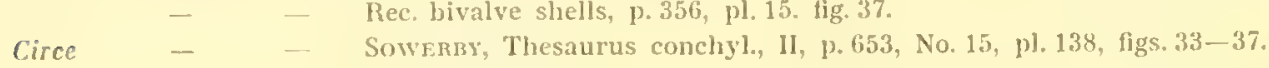

N. of Koh Kam, 5 fathoms, gravel (10). Between Koh Riot and Koh Mesan, 3-5 fathoms, sand (2). Gulf of Rayong, 7-10 fathoms, sand and mud (3). Koh Kahdal, 1-5 fathoms, sand (15). W. of Koh Kut, 15 fathoms, mud (5).

Long. $4-17 \mathrm{~mm}$.

Distribution:- Mergui Archip., Angrias Bank, Persian Gulf, Gulf of 'Tadjourall, Red Sea. - Philippines, Java, Viti Isls. 
The specimens taken in the Gulf of Siam vary considerably in regard to colour-ornamentation. Some are quite white, others white with a few brown spots, or with one or two broken-off brown rays, or with brown zigzag lines, etc.

\section{Circe lirata, Römer.}

(Pl. IV, Figs. 28-31).

Venus (Circe) lirata, Römer, Monogr. d. Molluskengatt. Venus, J, 1869, p.208, pl. 54, fig. 2.

Koh Kahdat, 1 fathom, sand (20).

Long. 7-24 $\mathrm{mm}$.

Long. $24 \mathrm{~mm}$., alt. $225 \mathrm{~mm}$., crass. $11.5 \mathrm{~mm}$.

Distribution:- "Mare chinense" (Römer).

The specimens from the Gulf of Siam correspond fairly well with Römen's description; the concentric, raised strixe are not so regular and prominent as shown in Römen's figure. The individuals vary greatly in regard to the coloration, and of the 20 specimens scarcely two are similar. The scale of colour graduates from quite white, to white with a few small hrown spots, or with brown rays, or with larger scattered brown spots, to almost entirely brown. In individuals measuring as much as $16 \mathrm{~mm}$. the whole shell is seen to be covered with the peculiar radiating sculpture which is characteristic of the species. The later growth of the shell is smoother, especially towards the ventral side. The great prominence of the umbonal region is very characteristic of this form. Gafrarium navigatum, Hedley, from Mast Head Reef (Queensland), ${ }^{1}$ is no doubt only a young individual of Circe lirata, Römer, or another closely allied form.

\section{Circe nana, Melv.}

Circe nana, Melvitl, Memoirs and Proc. of the Manchester Liter. and Philos. Soc., vol. 42, 1898, No. 4, p. 31, pl. 2, fig. 9 .

Proc. Zool. Soc. London, 1906, p. 831.

Between Koh Kut and Koh Kahdat, 10 fathoms, shells (1/2). "Gulf of Siam" ( $\left.{ }^{1 / 2}\right)$.

Long. 6-7.5 $\mathrm{mm}$.

Distribution: - Indian Ocean (long. $26^{\circ} 10^{\prime} \mathrm{N}$., lat. $52^{\circ} 50^{\prime} \mathrm{E}$.).

The figure which MELvilu gives of this species shows but imperfectly the beautiful sculpture which is produced by the fact that the grooves, which radiate from the umbo, turn off on either side and cross the fine concentric lira; but at the middle of the valves only the concentric striation is usually present.

\section{Circe Melvilli n. sp.}

(Pl. IV, Figs. 32-33).

This little species is roundly triangular in form, milky white, and rather convex; the umbo is situated at about the middle, but in some specimens slightly

1 Proc. Linnean Soc. New South Wales, vol. 31, 1906, p. 476, pl. 38, fig. 33. 
towards the anterior end. The dorsal margin descends abruptly on both sides, in front in an almost straight line, and at the back somewhat convexly. The ventral side is decidedly curving. The surface is covered with close-set, fine, concentric ribs, all of which do not, however, pass entirely round the valve, but are most of them incomplete and inserted irregularly between each other. Upon the anterior and posterior sides these ribs are crossed by fine radiating grooves which make the surface granulated at these places: these radiating grooves are at different distances apart and are most evident at the anterior end. At the upper part of the middle of the valves, somewhat below the beaks, at the point where the valves are most convex, the concentric ribs disappear and a bare glossy spot is formed. 'The lunule is large and lanceolate, circumscribed by a distinct impressed line, not affected by the radiating sculpture, but merely striated by fine lines of growth; a well-delined area does not occur. The interior of the shells is smooth, white and glossy. In the right valve there are three cardinal teeth of which the central is triangular; the anterior is small, and from it proceeds a lamellar tooth which is situated between the lateral tooth and the upper margin which is double. In the left valve there are also three cardinal teeth; the posterior is the smallest, it is compressed, narrow and acute. Each valve has an anterior lateral tooth, oblong, compressed and triangular, parallel with the upper margin and separated from it by a deep groove. The inner ventral margin is flat.

Long. $4 \mathrm{~mm}$., alt. $4 \mathrm{~mm}$, crass. $2.5 \mathrm{~mm}$.

Between Kol Rin and Cliff Rock, 15 fathoms (3/3). Gulf of Rayong, 7-10. fathoms, sand and mud (2/2). Koh Chuen, 30 fathoms (3/2). W. of Koln Chuen, mud mixed with clay (8/2). S. of Koh Chwen, 30 fathoms, shells (19/2). S. of Koh Samit, 20 fathoms, mud $\left(2+{ }^{10 / 2}\right)$. South-east of Koh Samit, 13-14 fathoms, mud mixed with sand (1/2). S. of Koh Tulu, 10 fathoms, mud mixed with sand (2/2). Sound of Koh Chang, 3-5 fathoms, soft clay (1/2). W. of Koh Chang, 20 fathoms, mud $(3+12 / 2)$. Between Koh Kut and Koh Kahdat, 10 fathoms, shells $\left(2+{ }^{12 / 2}\right)$. Between Koh Kahdat and Koln Kut, 6 fathoms, mud mixed with clay $(38 / 2)$. S. of Koh Kahdat, 8-10 fathoms, mud (19/2). W. of Koh Kut, 15 fathoms, mud (18/2). S. of Koh Kut, $17-20$ fathoms, mud $(1 / 2)$.

This characteristic and beautiful little species is common in the Gulf of Siam; it is nearest related to C. nana, Melv, and C. amica, Smith, from which it is, however, easily distinguished. I have ventured to dedicate this species to Mr. James Cosno Melvill, who, by his valuable papers, has contributed so largely to our knowledge of the marine Molluscan fauna of Asia.

\section{Circe (Lioconcha) picta, Lam.}

Cylherea picla, Lamarck, Hist. nat. d. anim. sans vert., V, 1818, p. 569, No. 33. - éd. 2, VI, 1835, p. 309, No. 33.

Lioconcha picla, Lıisanck, Römen, Malakozoolog. Blätter, IX, 1862, p. 144, No. 13.

Circe - LeEve, Conchol. icon., XIV, Circe, Sp. 42.

Cytherea (Iioconcha) picta, Lamanck, Römen, Monogr. d. Molluskengatt. Venus, I, p. 164, No. 15, pl. 45, fig. 3. Meretrix Avtroxy, Bull. du Muséum d'llist. Nat. Paris, 1905, p. 494. 
Gulf of Rayong, 7-10 fathoms, sand and mud (10). N. of Koh Kam, 5 fathoms, gravel (2). Between Koh Mesan and Cape Liant, 9 fathoms (2). Koh Kahdat, 1-10 fathoms, sand, mud (23). Koh Mak, sandy coast (t/2). W. of Koh Kút, 15 fathoms, mud (5).

Long. 3-32 $\mathrm{mm}$.

Distribution:- Andamans, Ceylon, Karachi, Persian Gulf, Laccadive and Maldive Archip., Red Sea, Obok (Aden), Tadjurah Bay, Mauritius, Rodrigues, Dur" ban (Natal). - Philippines, China, Japan, Blitong (post-tertiary), Torres Strait, Upolu (Samoa Isls.), Lifu (Loyalty Isls.), Funafuti (Ellice Isls.).

The individuals from the Gulf of Siam are all covered with a pale, rather thick, tallow-like epidermis, which is, however, usually somewhat worn off upon the umbones; the specimens agree in outline and colour more nearly with ReEve's figures. As the limits of the variation of this species are not fixed, authors ${ }^{1}$ have, in course of time, had very variable opinions regarding it and also as to how fa! several other forms should be referred to this species; it varies greatly both in outline and colour, and many closely allied forms, which are designated as species, will unquestionably prove to be only varieties and local forms, which is also indicated by the somewhat scattered distribution of the species, as far as it is at present known.

Circe (Lioconcha) trimaculata, Lam.

Cytherea trimaculata, Lamarck, Hist. nat. d. anim. s. vert., V, 1818, p. 571, No. 41. - éd. 2, VI, 1835 , p. 313 , No. 41.

Pullippr, Abbild. u. Beschreib. nener od. wenig gekannt. Conchyl., II, 1847, p. 179, Cytherea, pl. 5, fig. 2 .

Cytherca - - Sowerbx, Thesaur. conchyl., II, p. 641, No. 102, pl. 134, fig. 147.

Circe - - ReEve, Conchol, icon., XIV, Circe, Sp. 33.

Lioconcha - - KöMer, Monogr. d. Moll. Venus, I, p. 166, pl.46, tig. 2.

Koh Mak, sandy coast $\left({ }^{3 / 2}\right)$. The strand of Koh Kahdat ( $(2 / 2)$.

Long. $11-27 \mathrm{~mm}$.

Distribution:- Singapore, Andamans, Ceylon.-- Philippines, Viti Isls.

HIDALGo ${ }^{2}$ regards Lioconcha Sphragitis, Römer, ${ }^{3}$ as a variety of the present species.

\section{Circe (Lioconcha) sulcatina, Lam.}

Cytherea sulcatina, LAMARCK, Hist. nat. d. allim. s. vert., V, 1818, p. 568, No. 29. - éd. 2, VI, p. 308, No. 29.

Cytheraa - - Sowenns, Thesaurus Conchyl., II, p.641, No.101, pl. 134, figs. $145-46$.

Circe - Refve, Conchol. icon., XiV, Circe, Sp. 40.

Cytherea (Lioconcha) sulcatina, LAMAnck, Römen, Monogr. d. Molluskengatt. Venus, I, p. 165, pl. 46 , fig. 1.

1 L. Pfeiffer in Martixi u. Chemnitz, Conchyl. Cabin., XI Bd., 1 Abth., 1869, p. 39. - A. H. Cooke, Annals and Magaz. Nat. Hist. 1886, Ser. 5, vol. 18, p. 101. - CAsto de ELERA, Fauna de Filipinas, UII, p. 743. - EDG. A. Sмrтн, Rep. on the Lamellibranchiata of the Challenger Exped., pp. 146-47. - EDr. Y. Martens, Rumphius Gedenkboek, 1902, p. 125 (17).

2 Hidalgo, Obras malacológicas, I, Tome II, 1903, p. 220.

3 Römer, Monogr. d. Moll. Venus, I, p. 162, No. 13, pl. 43, fig. 3.

D. K. D. Vidensk, Selsk. Slkr., 7. Rekke, naturvidensk. of mathen. Afa. V. 3. 
Cytherea sulcatina, Lamancr, Pfenfer in Mantini u. Chemnitz, Conchyl. Cabin., XI Bd., 1 Abth., p. 36. pl. 12, tigs. $1-2$.

Lioconcha - - Hidalgo, Obras malacológicas, I, tom. II, 1903, p. 219, No. 329.

Meretrix (Lioconcha) sulcalina, Lamarci, Anthony, Bull. du Muséum d'Hist. Nat. Paris, 1905, p. 494.

North of Koh Kahdat, 4-5 fathoms, sand (1/2).

Long. $34 \mathrm{~mm}$.

Distribution: - Maldive Archip., Tadjurah Bay. - Philippines, Lifu.

In "Museum Godeffroy," Catalog V, 1874, p. 169, C. sulcatina, Desh., is recorded from "Africa merid." but this is perhaps due to erroneous determination.

\section{Circe (Crista) gibbia, Lam.}

Cytherea gibbia, LAMARck, Hist. nat. d. anim. s. vert., V, 1818, p. 577, No. 64. -- éd. 2, VI, 1835, p. 323, No. 64.

Circe - - - Sowerby, Thesaur. Conchyl., 1I, 1855, p. 649, No. 2, pl. 137, figs. 4-7.

Cytherea (Crista) gibbia, Lamarck, Römer, Malakozool. Blätter, X Bd., 1862, p. 17, No. 2.

Circe gibba, LaMakci, Revve, Conchol. icon. XIV, Circe, Sp. 21.

Cytherea gibbia, Lamanck, Martini u. Chemnitz, Conchyl. Cabin., XI Bd., 1 Abth., p. 51, No. 36, pl. 18, figs. $7-9$.

(Crista) gibbia, Lamanck, Römer, Monogr. d. Molluskengatt. Venus, I, 1869, p. 176, pl. 47, fig. 2.

Circe gibbia, Lamanck, Edg. Smith, Rep. on the Lamellibranchiata of the Cliallenger Exped., p. 143.

(Crista) gibbia, Lamarck, Fischer, Catalogue d. Moll. de l'Indo-Chine, p. 231.

Crista gibbia, LaMarck, Hidalgo, Obras malacológicas, I, tom. II, 1903, p. 231, No. 336.

- - - Dautzenberg et Fischer, Journ. de Conchyl., vol. 53, 1905, p. 213

Cytherea ranella, Lamarck, Hist. nat. d. anim. s. vert., V, 1818, p.578, No. 65.

Coast of Lem Ngob (7). Coast of Koh Chang (8). North end of Koh Chang, 1 fathom, old coral blocks (2). Koh Kahdat ( $1 / 2)$.

Long. $36 \mathrm{~mm}$.

Islands in the Gulf of Siam (MORLET).

Distribution: - Singapore, Mergui Isls., Andamans, Nicobars, Madras, Ceylon, Red Seat (?), Scychelle', Amirantes. - Tonkin, Hong Kong, Formosa, Shanghai, Japan, Philippines, Java, Moluccas, Macassar, New Guinea, Port Denison, New Caledonia, South Sea Isls. (Mus. Godeffroy).

At present I can see no reason for regarding C. gibbia, Lam., and C.pectinata L. as forms of the same species, as do several authors. ${ }^{1}$

\section{Circe (Crista) pectinata, L.}

Venus pectinata, Linné, Syst. Nat., ed. X, 1758, p. 689, No.120. - ed. XII, p. 1135, No. 144. - ed. XIII, p. 3285, No.78. - Mus. Ludov. Ulrice reg., p. 507, No. 72.

- - - C Clieminz, Conchyl, Cabin., VII, p. 28, pl. 39, figs. 418-19.

Cylherea Savignyi, Josas, Zeitschr. f. Malakozool., 1846, p. 65.

SAvigny, Descr. de l'Égypte, Coquilles, pl. VIII, fig. 17.

- Crista) Savignyi, Jonas, Issel, Malacol. d. Mar Kosso, 1869, p. 70, No. 67.

Circe pectinata, Linné, Sowerir, Thesaur. conchyl., II, p. 649, pl.137, figs. 1-3.

I PAGENTECHER, Ueber die von Kossmann am Rothen Meere gesamm. Mollusken, 1877, p. 40. Melvill and Standen, Journ. Línn. Soc., Zoology, vol. 27, p. 194. - Mörch, Catal. conchyl. quxe reliq. C. P. Kieruli, 1850, p. 23. 
Circe pectinata, LInné, Rerve, Conchol. icon, vol. XIV, Circe, Sp. 20.

Cytherea pectinata, Linné, Martini u. Chemnitz, Conchyl. Cabin., XI, I Abth., p. 50, pl. 18, figs. 10 - 11. - (Crista) pectinata, Linxé, Römer, Monogr. d. Moll. Venus, I, 1867, p. 174, pl. 47, fig. 1.

Circe - _ _ Fischer, Moll. de l'Indo Chine, p. 231.

- - - - - R. Bullen Newton, The Geological Magazine. New Ser. Dec. IV, vol. 7 , 1900 , p. 555 , pl. 21 , fig. 3.

Crista pectinata, Linné, Hidalgo, Obras malacologicas, I, tom. II, 1903, 13. 228, No.335.

Koh Kahdat, $1-5$ fathoms, sand, stones $(1+5 / 2)$. Koh Mak, sandy coast $(2 / 2)$. Long. 7-20 $\mathrm{mm}$.

"Golfe de Siam" (Fischer).

Distribution: - Andamans, Madras, Gulf of Manaar, Persian Gulf, Gulf of Aden, Red Sea, Suez, Suez Canal, Seychelles, Amirantes, Querimba Isls., Madagascar, Mascarenes, Natal coast, Port Elizabeth, Cape of Good Hope. - Poulo Condor, Philippines, China, Loo Choo Isls., Moluccas, Timor, Adenare, Bencoolen, New Guinea, Kei Bandan, 'Torres Strait, North-east Australia, New Caledonia, Mariannes, Gilbert Isls., Funafuti (Ellice Isls.), Viti Isls., Lord Hood's Isl., Upolu (Samoa Isls.), Paumoto Isl., Flint IsI. (PILsbry).

\section{Circe (Crista) dispar, Ch.}

Venus dispar, Cinesnitz, Conchyl. Cabin., XI, 1795, p. 230, pl. 202, figs. 1981-82.

Circe - - - SowerịY, Thesaur. Conchyl., II, 1855, p. 650, pl. 137, figs, 10-11; pl. 163, figs. $53-54$.

- - - ReEve, Conchol. icon., XIV, Circe, Sp. 21.

Cytherea dispar, - Martini u. Chemsitz, Conchyl. Cabin., XI, 1 Abth., p. 32, pl.11, figs.5-6.

- (Crista) dispar, Chemxitz, Römer, Monographie d. Molluskengatt. Venus, I, 1869, p. 184, pl. 50, fig. 1 ; pl. 51, fig. 4 .

Koh Mak, sandy coast (3). North end of Koh Chang, 1 fathom, old coral blocks (1).

Long. $24 \mathrm{~mm}$.

Distribution:- Nicobars (Frauenfeld), Ceylon (Chemnitz, Hanley, Schlagintweit), Gulf of Manaar (Thurston), Ins. Bourbon (MAlldard). — Japan (Lischre, Adams), New Caledonia (Fischer, Frauenferd).

This species has been recorded hy Deshayes, ISSEL, and ReEve from the Red Sea, but none of the later authors (M'Andew, A. H. Cooke, PAgenstecher, L. VailLant, Edg. Smith, Jousseaume, E. R. Shopland) record it either from the Red Sea, Suez or Aden.

\section{Circe (Crista) divaricata, Ch.}

Venus divaricata, Chemnitz, Conchyl. Cabin., VI, 1782, p. 317, pl. 30, fig. 316.

Circe aquivoca, Sowenny, Thesaurus Conchyl., 1I, 1855, p. 650, No. 4, pl. 137, figs. 12-15 (non No. 3, C. divaricala).

- divaricata, Chemitz, Reeve, Conchol, icon., XIV, Circe, Sp. 23.

Cytherea - - Martini u. Chemsitz, Conchyl. Cabin., XI 13d., I Abth., p. 44, pl. 16 , fig. 8.

Venus (Crista) divaricata, CHемnтz, Römer, Monogr. d. Molluskengatt. Venus, I, p. 181, pl. 49, fig. 1; pl. 51 , fig. 5. 
Circe Crista) divaricata, Chemnitz, Fischer, Catalogue d. Moll. de l'Indo-Chine, p. 231.

Crista divaricata, Chennitz, Hidago, Obras malacológicas, I, tom. II, 1903, p. 233, No. 337.

- - - Dautzenberg \& Fischen, Journ. de Conchyl., vol. 53, 1905, p. 458.

Koh Mak, sandy coast $\left({ }^{1} / 2\right)$.

Long. $36 \mathrm{~mm}$.

Islands in the Gulf of Siam (MorLET).

Distribution:- Singapore, Salang, Mergui Archip., Andamans, Madras, Gulf of Manaar, Bombay, Karachi, Persian Gulf, Gulf of Oman, Red Sea (?), Zanzibar, Mozambique, Natal, Seychelles (Dautzenberg). - Poulo Condor, Annam, Philippines, Hong Kong, Shanghai, Japan (Dunker), Japan (Inland Sea, Stearns).

In spite of the statements of ReEve, Sowerby and Isser, it is doubtful whether C. divaricala, Ch., occurs in the Red Sea. Later authors do not record it with certainty from Aden or from the Red Sea. When PAGENSTEcuER ${ }^{1}$ says regarding this species: "Von sechs Exemplaren gehören vier der Varietät gibba Lam;, eins. der pectinata Lin. an," he has evidently had other species before him.

\section{Tapes (Paratapes) papilionaceus, Lam.}

Venus papilionacea, Lanarck, Hist. nat. d. anim. s. vert., V, 1818, p. 594, No. 36. - éd. 2, VI, p. 352 , No. 36. Tupes - - Sowerny, Thesaurus Conchyl,, II, p. 679, No. 2, pl. 145, figs. 1-2.

... rotundata, REEVE, Conchol. icon., XIV, Tapes, Sp. 7.

Venus papilionacea, Lamarck, PFeiffer in Martini u. Chemnitz, Conchyl. Cabin., XI l3d., 1 Abth., p. 167 No. 33 , pl. 15 , fig. 6 .

Tapes (Tex/rix) papilionacea, LaMarCi, Römer, Monogr. d. Moll. Venus, II, p. 21, No. 3, pl.6, fig. 1. papilionacea, Lamarcs, Crosse et Fischer, Journ. de Conchyl., vol. 40, 1892, p. 76.

West coast of Cambodge in the Gulf of Siam (PAviE).

Distribution: - Ceylon, Mauritius, Madagascar. - "New Holland," West Australia.

It is strange that this large, conspicuous, and well-known species, will the exception of the above quotation, has not been taken in the Gulf of Siam or adjacent waters, either by the Danish Expedition or by others. Can it perhaps be due to erroneous determination of $T$. semirugatus, Phil., when the specimen collected by PAvie, is given as $T$. papilionaceus, Lam., by Cnosse and Fischer?

\section{Tapes (Paratapes) semirugatus, Phil.}

Venus semirugala, PHupl, Zeitschrift f. Malakozoologie, IV, 1847, p. 88, No. 22.

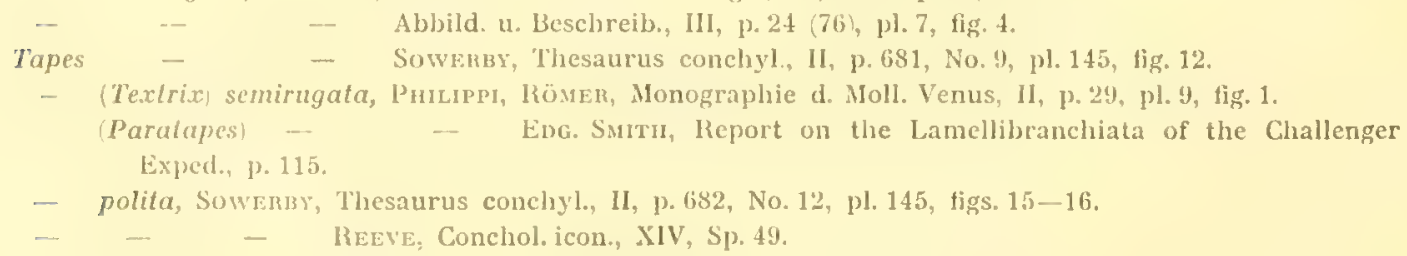

${ }^{1}$ Ueber die vom IR. líossman am Rothen Meere gesamm. Mollusken, 1877, p. 40. 
S. of Koh Chuen, 30 fathoms, shells (4). Between Koh Chuen and Koh Chang, 15 fathoms, mud (1). West side of Koh Chang (1/2). W. of Koh Kut, 30 fathoms, sand and mud $(8 / 2)$. W. of Koh Kut, 15 fathoms, mud (1).

Long. 6-53 $\mathrm{mm}$.

Distribution:- New Guinea, Inland Sea (Japan, Stearns), Sydney.

All the specimens from the Gulf of Siam, like EDG. Smitr's individual from New Guinea, have the four interrupted, brown rays from the umbo to the ventral side very marked; on the other hand, "Lhe brown apices to the umbones" cannot, as EDG. SMITH assumes, be regarded as characteristic of this species, for among the individuals, both the large ones and the eight young $(=T$. polita, Sow.), which I have before me, only one exhibits a slight indication of lilac at the tip of the umbones.

Tapes (Paratapes) undulatus, Born.

Venus undulata, Bors, Index Mus. Cres. Vindobon., 1778, p. 54. - Testacea Musei Cuesarei Vindobon., 1780, p. 67.

Tapes - - ReEve, Conchol. icon., XIV, Tapes, Sp.8.

- (Textrix) undulata, Borv, Bömer, Monogr. d. Moll. Venus, II, p. 20, No. 2, pl. 5, fig. 2.

- undulatus, BonN, Lrscuke, Japan. Meeres-Conchylien, II, p. 171, 11I, p. 80.

- (Paratapes) undulata, Bonn, Edg. Sinth, Report on the Lamelibranchiata of the Challenger Exped., p. 115.

- undulatus, Bors, Fischer, Catalogue d. Moll. de l'Indo Chine, p. 273.

Yenus rimosa, Philippi, Zeitschr. f. Malakozool., IV, 1847, p. 88, No. 21.

- - _ Abbild. u. Beschreib., 11I, p. 77 (25), pl. 7, fig. 7.

Tapes - - Sowerbr, Thesaurus Conchyl., 11, p. 682, No. 11, pl. 146, fig. 29.

Koh si Chang (1/2). Sound of Koh Chang, 3-5 fathoms, soft clay, exceedingly common, a great many specimens. West of Koh Chang, 20 fathoms, mud (2). W. of Koh Kut, 15 fathoms, mud (1/2). North of Koh Kong, 8 fathoms, mud (1).

Long. 6-60 $\mathrm{mm}$.

Gulf of Siam (MorLeT).

Distribution:- Mergui Archip., Ceylon, Mekran Coast, Persian Gulf. - Philippines, China, Japan, Arafura Sea, Port Jackson and Sydney Harbour, Bass Strait.

Tapes (Protapes) Malabaricus, Ch.

Venus Malabarica, Chemsitz. Conchyl. Cabin., V1, 1782, p. 323, pl.31, figs. 324-25.

Tapes - $\quad-\quad$ Soweriy, Thesaurus Conchyl., 1I, p. 682, pl. 145, figs. 6-8.

- - - Re Rev, Conchol. icon., XIV, Sp. 27.

Venus malabarica, - L. PFeifler in Martini u. Chemsitz, Conchyl. Cabin., XI Bd., 1 Abth., p. 175. pl. 17, figs. $1-2$.

Tapes (Textrix) Malabarica, Chennitz, Römen, Monogr. d. Molluslengatt. Venus, II, p. 34, pl. 10, fig. 3.

- Malabaricus, Chemnitz, P. Fischer, Catalogue d. Moll. de l'Indo Chỉe. p. 234.

- - - Edg. SMith, Proc. Zool. Soc. London, 1891, p. 424.

Venus rhombifera, HanLEx, Catalogue of recent bivalve shells, p. 120, pl. 13, fig. 45.

Tapes lentiginosa, ReEve, Conchol. icon., XIV, Sp. 25 (fide Edg. Sirth).

Between Koh Mesan and Cape Liant, 5-9 fathoms (1). N. of Koh Kam, 5 fathoms, gravel (1/2). Coast of Lem Ngob (3/2). Between Kioh Kahdat and Koh Kut, 6 fathoms, mud mixed with sand (2). W. of Koh Kut, 15 fathoms, mud $\left({ }^{1} / 2\right)$. 
Long. $12-53 \mathrm{~mm}$.

Distribution:-- Bintang, Mergui Archip., Andamans, Madras, Ceylon, Gulf of Manaar, Malabar Coast from Goa to Bombay, Karachi, Persian Gulf, Aden. Annam, Poulo Penang, China, Philippines, Moluccas, Torres Strait, Port Molle.

"Venus gallus, Spengler," which J. S. ScHnören ${ }^{1}$ correctly gives as a synonym, cannot, as suggested by Römer ${ }^{2}$ and PFEmfer, ${ }^{3}$ have the priority of Chemnitz's name, ${ }^{*}$ as $V$.gallus is merely a museum-name. Upon the label attached to SPENGLER's specimens of T.malabaricus (which are now in the Museum of the University of Copenhagen) is written in SPEngLer's handwriting: "Venus Gallus Forskaal" and reference is made to Chemnitz, Conchyl. Cabin., VI; neither Fonskil nor Spengler have published the name before Chemsitz.

As is well-known, this species varies considerably both in regard to form and sculpture; from the Gulf of Siam were collected both the oblong (long. $46.5 \mathrm{~mm}$., alt. $32.5 \mathrm{~mm}$.), and the high and relatively shorter form (long. $54 \mathrm{~mm}$., alt. $42 \mathrm{~mm}$.); as also individuals with very close-set and fine transverse ribs, and others with coarse, broad and flat transverse ribs.

Tapes (Protapes) sinuosus, Lam.

Venus sinuosa, Lamarck, Hist. nat. d. anim. s. vert., V, 1818, p. 604, No. 72 - éd. 2, vI, 1835 , p. 366, No. 72. Tapes - - Sowerbr, Thesaurus Conchyl., II, p. 683, No. 14, pl. 145, fig. 10.

- - - ReEve, Conchol, icon.. XIV, Tapes, Sp. 18.

- (Texirix) sinuosa, Lamarck, Rösfr. Monogr. d. Molluskengatt. Venus, II, p. 35, No. 16, pl. 11 , fig. 1.

- Malabaricus, Chemnitz var. sinnosus, Lamarck, Martens, Journ. of the Linnean Society, XXI; 1887, pp. $213-14$.

E. of Cape Liant, 9 fathoms, shells (2). S. of Koh Chuen, 30 fathoms, shells (3). Between Koh Kut and Koh Kahdat, 10 fathoms, shells $(1 / 2)$.

Long. $24-36 \mathrm{~mm}$.

Distribution:- Salang, Mergui Archip. - China, "Australia".

$T$. sinuosus, Lam., is nearly allied to T.malabaricus, Chemn., but among the material at my disposal it has always been easy to distinguish these two forms. "The most conspicuous distinguishing feature in $T$. sinnosus, is the large "Tellinacurvature" which causes the hinder end to be abruptly truncated. "The transverse ribs are narrow and thin, high, sharp and lamellate and are continued over the lunule and the area. The interstices between the ribs are deep, broad, and regular. Whether these features are constant, future investigations will show.

Tapes (Hemitapes) hiantinus, Lam.

Venus hiantina, Lanarick, Hist. nat. d. anim. s. vert., V, 1818, p.593, No. 32. 一 éd. 2, VI, p. 350 , No. 32. Dizessent, Recueil de coquilles décr. p. Lamarck, pl. 10, fig. 8.

\footnotetext{
1 Einleit, in d. Conchylienkenntniss, III, 1786, p. 159, No. 14.

Krit. Unters. d. Arten d. Molluskengeschl. Venus, 1856, p. 68.

3 Mantini u. Chemsitz, Conchyl. Cabin., X1 Bd., 1 Abth., p. 176.

+ Gmrin, Syst. Nat., ed. Xill, p. 3277, has also adopted the name "Gailus."
} 
Venus hiantina, Lamanck, Philmpi, Abbild. u. Beschreib. neuer od. wen. gek. Conchyl., III, p. 21 (27), pl.8, fig. 1.

Tapes -- _ ReEve, Conchol. icon., XIV, Tapes, Sp. 28.

- - - Kömer, Monogr. d. Molluskengatt. Venus, II, p. 99, pl. 34, fig. 1.

Venus fammulata, - Hist. nat. d. anim. s. vert., V, 1818, p. 605, No.77. - éd. 2, VI, p. 367, No. 77.

Tapes - - $\quad-$

Venus rimularis, -

Tapes $-\quad-\quad-$

Sowerby, Thesaur. conchyl., II, p. 686, No.26, pl. 148, figs. 56-61.

Hist. nat. d. anim. s. vert., V, p. 604 , No. 74 . - éd. 2, p. 367, No. 74.

Sowerby, Thesaur. conchyl, II, p. 687, No. 27, pl. 148, fig. 55.

ReEve, Conchol. icon., XIV, Tapes, Sp. 29.

- - - - -

Verus tristis, -

$\begin{array}{lll}- & - & - \\ - & - & -\end{array}$

Tapes - $\quad-$

- $\quad$ - $\quad$ Bucooy, Dautzenbers \& Dollfus, Moll. mar. de Roussillon, II, p. 399.

Hist. nat. d. anim. s. vert., V, p. 604, No. 73. - éd. 2, VI, p. 366, No. 73.

Delessert, Recueil de coquilles, pl. 10, fig. 10.

Philippi, Abbild. u. Beschreib., I, p. 2 (40), pl. 1, fig. 4.

ReEve, Conchol. icon., XIV, Tapes, Sp. 44.

Röser, Monogr. d. Molluskengatt. Venus, II, p. 100, No. 78, pl. 34, fig. 2.

Hidalgo, Obras malacológicas, I, tom. II, 1903, p. 260, No. 358.

Venus callipyga, Hist. nat. d. anim. s. vert., V, p.601, No.61. - éd. 2, VI, p. 361, No. 61.

- vulvina, -

- virginea, LINNÉ,

Syst. Nat. ed. XII, p. 1136, No. 150 (ex parte).

- - - Philippi, Abbild. u. Beschreib., 111, p.22 (28), pl.8, figs. 2-4.

- - - Martini u. Chemintz, Concliyl. Cabin., XI, 1 Abth., p. 201, pl. 32, figs. 9-10.

Tapes - - (non auct. plur.) Römer, Monogr. d. Molluskengatt. Venus, II, p. 98, No. 76, pl. 33, fig. 3.

- virgineus, - Hibalgo. Obras malacológicas, I, tom. II, 1903, p. 262, No. 360.

- - - Dautzenberg et Fischer. Journ. de Conchyl., vol. 53, 1905, p. 224.

Coast of Lem Ngob (3). Coast of Koh Chang (3).

Long. $37-42 \mathrm{~mm}$.

Distribution: - Karachi (Melvill \& Standex), Aden (Edg. Syitir). - Philippines, Tonkin, China, Moluccas, Torres Strait, "New Holland."

LINNÉ's "Venus virginea" is a collective species which includes the European Tapes rhomboides, Penn., and the East Indian T. hiantinus, Lam. The limits and the variability in form of the latter species have not yet been sufficiently investigated, and in the future it will doubtless be proved that it includes still more forms than the Lamarckian species mentioned above. The specimens from the Gulf of Siam agree most closely with the T.hiantinus-tristis forms.

\section{Tapes (Ruditapes) Philippinarum, Ad. \& Reeve.}

Venus (Pullastra) Philippinarum, A. ADass and REEve, The Zoology of the voyage of H. M. S. "Samarang." Mollusca, 1848, p. 79, No. 1, pl. 22, fig. 10.

Tapes Philippinarum, A. Adass and Reeve, Sowerby, Thesaurus Conchyl, 1I, p. 694, No. 54, pl.151, figs. $139-41$.

- ReEve, Conchol. icon., XIV, Tapes, Sp. 60.

- (Amygdale) Philippinarum, A. Adams and ReEve, Römer, Monogr. d. Moll. Venus, II, p. 80, No.60, pl. 28, fig. 2.

- Philippinarum, A. Adans and Reeve, Lischke, Japan. Meeres-Conchylien, I, p. 115; II, p. 108; III, p. 78.

- (Cuneus) Philippinarum, A. AdAs and ReEve, Duxker, Index molluscor. mar. Japon., p. 207.

- Japonica, Deshayes, Proc. Zool. Soc. London, XXI, 1853, p. 10, No. 4 (non Venus japonica, Gmel. = Tapes striatus, (Chemn.) Gmel.).

- Indica, Hanley, Sowerby, Thesaurus Conchyl., II, p. 694, No.55, pl. 151, figs. $146-47$.

- - - Reeve, Conchol. icon., XIV, Tapes, Sp. 56. 
Tapes (Amygdale) indica, Haxlex, llömen, Monogr. d. Moll. Venus, II, p. 75, pl. 26, fig. 1.

- Indicus, Hanley, Hidalgo, Obras malacológicas, I, tom. II, 1903, p. 273, No. 369.

- denticulata, Sowerвæ, Thesaurus Conchyl., II, p. 694, No. 53, pl. 150, fig. 114.

- - - ReEve, Conchol. icon., XIV. Tapes, Sp. 63.

- (Amygdale) denticulata, Sowerny, Röser, Monogr. d. Moll. Venus, II, p. 74, p]. 25, fig. 3.

- semidecussata, Desnayes, Relive, Conchol. icon., XIV, Tapes, Sp. 67.

- Amygdale) semidecussata, Desnares, Römer, Monogr. d. Moll. Venus, 11, p. 79, pl. 28, fig. 1.

- - ducalis, Röмек, Monogr. d. Moll. Venus, II, p. 81, pl. 28, fig. 3. - Malakozool. Blätter, XVII, 1870, p. 9, No. 7.

Lischie, Japan. Meeres Conchyl, III, pl. 5, tigs. 17-20.

Strand of Koh Kahdat (1/2 worn specimen). Coast of Koh Chang (2).

Long. $14-27 \mathrm{~mm}$.

Distribution: - Andamans, Ceylon, Bombay, Karachi. - Philippines, China, Formosa, Korea, Japan, Sachalin, South Sea Islands (Mus. Godeffroy).

The variability of this species has not yet been sufficiently investigated. It comes near T. variegalus, Sow, and the European T. decussatus L. JEFrREys ${ }^{1}$ even thinks that "it is impossible to separate the so-called $T$. indicus from $T$. decussatus by any other than a geographical character."

\section{Tapes (Ruditapes) variegatus, Hanl.}

Tapes variegata, Hanlex, Sowerby, Thesaurus conchyl., II, 1855, p. 696, No.61, pl. 151, figs. 133 and $136-38$ (figs. $134-35=T$. puniceus, Desh.).

- - - $\quad$ - REeve, Conchol. icon., XIV, Sp. 64.

V'enus - - Martini u. Chemnitz, Conchyl. Cabin., XI Bd., 1 Abth., p. 223, pl. 38, figs. $2-5$.

Tapes variegatus, SowermY, Lischke, Japan. Meeres-Conchyl., I, p. 118; III, p. 79.

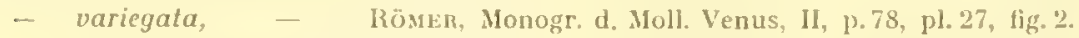

- (Cuneus) variegatus, Hanıey, Dunker, Index molluscor. mar. Japon., p. 207.

- variegatus, Soweris, Monlet, Journ. de Conchyl., vol. 37, 1889, p. 170, No.71.

- _ Hanley, Hidalgo, Obras malacológicas, 1, tom. II, 1903, p. 721, No. 370.

The strand of Koh Kahdat (1/2). Koh Mak, sandy coast (1/2).

Long. $15-18 \mathrm{~mm}$.

"Golfe de Siam" (Morlet).

D istribution:- Salanga, Mergui Archip. - Philippines, Hong Kong, Japan, Java, Port Curtis, Port Denison, Samoa Isls., 'Tahiti.

I think that $T$. violascens, Desh., can scarcely be separated from $T$. variegatus, Sow.

\section{Tapes (Parembola) radiatus, Ch.}

Venus lilerata, radiata, Cnemnitz, Conchyl. Calsin., VII, 1784, p. 45, pl. 42, fig. 439.

Tapes aspersa, ReEve, Conchol. icon., XIV, Tapes, Sp. 5 (non Chemnitz).

- radiala, Chemeitz, Römen, Monogr. d. Moll. Venus, II, p. 41, pl. 14, fig. 3.

Venus - - Pefiffer in Martini u. Chemnitz, Conchyl. Cabin., Xi, 1 Abth., p. 160, No. 28, pl. 15, fig. 1.

Tapes radiatus, - L. Monlet, Journ. de Conchy1., vol. 37, 1889, p. 170, No. 70.

Hidalgo, Obras malacológicas, I, tom. II, 1903, p. 245, No. 346.

1 The Journal of the Linnean Socicty, Zoology, vol. X11, 1876, p. 105. 
Islands in the Gulf of Siam (L. MondeT, loc. cit.).

D istribution:- Nicobars, Aden. - Philippines, Java, Sulu Isls., Torres Strait.

The Danish Expedition obtained no specimens of this species from the Gulf of Siam. E. v. Martens ${ }^{1}$ records T. radiatus, Gm. (ReEve, Fig. 16 a, non Römer, Pl. 14, Fig. 3), from Seychelles.

\section{Tapes obscuratus, Desh.}

Tapes obscurata, Deshayes, Proc. Zool. Soc. London, XX1, 1853, p. 9, No.38. - Catalogue of the Conchifera of the Brit. Mus., I, 1853, p. 169, No. 29.

- - - ReEve, Conchol, icon., XIV, Tapes, Sp. 12.

- (Parembola) obscurata, Deshayes, Rösier, Monogr. d. Moll. Venus, II, p. 52, No, 32, pl. 18, fig. 3.

- obscurata, Drshives, EDG. SMiтh, Lamellibranchiata of the Challenger Expedit., p. 113.

- quadriradiala, Deshayes, Proc. Zool. Soc. London, XXI, 1853, p. 9, No. 40, pl. 19, fig. 6. - Catal. Conchif. Brit. Mus., I, 1853, p.171, No. 34.

$\begin{array}{clll}- & - & - & \text { Reeve, Conchol. icon., XIV, Tapes, Sp. 6. } \\ \text { Venus } & - & - & \text { Römer, Monogr. d. Moll. Venus, 11, p. 51, No. 31, pl. 18, fig. } 2 .\end{array}$

Tapes quadriradialus, Deshayes, Hodago, Obras malacológicas, I, tom. II, 1903, p. 253, No. 354.

grata, Deshayes, Proc. Zool. Soc. London, XXI, 1853, p. 9, No. 41. - Catal. Conchif. Brit. Mus., p. 170, No. 31 .

- similis, REEve (non Drshayes), Conchol. icon., XIV, Tapes, Sp. 10.

Koh Mak, sandy coast $(1 / 2)$.

Long. $43 \mathrm{~mm}$.

Distribution:- Singapore, Salanga, Mergui Archip., Ceylon? (W. Denison), Aden. - Philippines, Moluccas.

\section{Cryptogramma squamosa L.}

Venus squamosa, Lixke, Systema Naturae, ed. X, 1758, p. 688, No. 111 ; ed. XII, p. 1133, No. 135.

- $\quad$ - Sowerby, Thesaurus Conchyliorum, II, 1855, p. 716, No.38, pl. 156, figs. 83-81.

- - Rervis, Conchol. icon., rol. XIV, Venus, Sp. 101.

Cryplogramma squamosa, Linné, Rörér, Malakozoolog. Blätter, XIV Bd., 1867, p. 26, No. 10.

Ienus - - Martini u. Chevnitz, Conchyl. Cabin., XI, 1 Abth., p. 178, pl, 17, tig. 12. - (Cryptogramma) squamosa, Linsé, Fischer, Catalogue d. l'Indo-Chine, p. 233.

- - - - - Dautzenibrg et Fischer, Journ. de Concliyl., vol. 53, 1905, p. 222.

The strand of the Mangrove at the station on Koh Chang, in very shallow water (2).

Long. $24 \mathrm{~mm}$.

Islands in the Gulf of Siam (Morket).

Distribution:- Singapore, Mergui Isls., Gulf of Manaar. - Poulo Condor, Plilippines, Tonkin, Hong Kong, Formosa, Japan, Moluccas, Sydney (Frauexfidi).

1. Die Mollusken d. Maskarenen u. Seychellen, 1880, p.151. In v. 1). DEcknv's Reise in Ost-Afrika, 1869, he records T. radiala, Anton (Chemn., VII, fig.439), from Seychelles.

u. K. I). Vidensk. Selsk. Skr., 7. Rakke, noturvidensk. of mathem. Afu. V. 3. 
Chione (Omphaloclathrum) marica L. (Sow.).

(P1. V, Figs. 1-4).

Venus marica, Linn.eus, Sowerby, Thesaurus Conchyl., II, p. 719, No.47, p]. 157, fig. 108

Between Koh Riot and Koh Mesan, 3-5 fathoms, sand (1/2). N. of Koh Kahdat, 4-5 fathoms, coarse sand (2). W. of Koh Kut, 15 fathoms, mud (1).

Long. 8-19 $\mathrm{mm}$.

Distribution?

EDG. Smith says in the report on the Lamellibranchiata of the Challenger Expedition (p. 125) "This species (Venus (Chione) marica L.) is so well known that it is unnecessary to give further references than those above mentioned." "This may be true as regards the name, because from as far back as the times of LiNer and Cincmitz it has constantly been recorded and mentioned from many localities all over the globe; but a comparison of the descriptions and figures given by LiNNE, Chemnitz, Sowerisy, ReEve and others leaves an impression of great uncertainty with regard to the characteristics and limits of the species. For instance, it appears to me that Linné-Chemnitz's species can scarcely be identical wilh Sowerby's Ch. marica, 'Thes. Conchyl. fig. 108 (EDG. Smutu's species Ch. recognita is undoubledly also frequently confused with $C h$. marica). All the individuals from the Gulf of Siam agree precisely with SowErBY's figure 108, but how far that is identical with, or is a form of LinNê's Ch. marica is perhaps doubtful. I have given a figure of the specimens from the Gulf of Siam to fix the form for future comparisons. The specimens from MolTke's collection, from which Chemnitz had his figures 282-84 made (Pl. 27 in the "Conchylien Cabinet". Figs. 285-86 scarcely belong here), exist no longer in the MoLTKE collection included in the Zoological Museum of the University of Copenhagen, so I have not been able to compare CHemvitz's specimens with mine from the Gulf of Siam. STURANY" is inclined to regard "Venus Römeriana, Issel," from the Red Sea, as a young form of Ch. marica $\mathbf{L}$.

\section{Chione (Omphaloclathrum) recognita, E. Sm.}

Venus (Chione) recognita, EDs. SMITH, Report on the Lamellibranchiata of the Challenger Expedition, 1885, p. 125, pl. 3, fig. 5.

- Marica, ReEve p. p., Concholog. icon., XIV, 1863, Venus, fig. 104 a (non 104 b and c).

Koln Kahdat, sand, $1-5$ fathoms $(70)$. N. of Koh Kahdat, $4-5$ fathoms, sand (14). Koh Mak, sandy coast ( $/ 2)$. S. of Koh Mak, 5-6 fathoms (2). W. of Koh Kut, 15 lathoms, mud (4).

Long. $6.5-20 \mathrm{~mm}$.

Long. $20 \mathrm{~mm}$, alt. $15 \mathrm{~mm}$, crass. $10 \mathrm{~mm}$.

- $17 \mathrm{~mm} .$, - $135 \mathrm{~mm}$, — $8.5 \mathrm{~mm}$.

Distribution:- Suvativa Atoll (Maldive Archip.), Philippines. - Mast Head Reef, Queensland (HEDLEY).

Lamellibranchiaten d. Rothen Meeres, 1899, p. 27. 
This beautiful species is doublless often confused with Ch. marica $\mathrm{I}_{\text {., }}$ which it somewhat resembles, and it is probably more widely distributed than is at present known. The specimens from the Gulf of Siam vary greatly both in outline and in colour, most of them are not as high as is shown in Surth's figure (but the measurements given in the text agree fairly well with those of my specimens), and resemble more closely REEve's figure (loc. cit.), which I think ought to be referred to the present species. 'The coloration varies exceedingly, there are scarcely two specimens which are alike in regard to painting; pale-red, white, and yellow individuals occur, with brown or red zigzag-lines, spots and rays, and many other paintings. In the interior of the valves the colour varies from entirely white to dark lilac. As the lamella upon the posterior end are often only slightly conspicuous, I think that AnAus's and REFve's species Venus costellifere is nothing but an individual of Ch. recognita, Sm., with worn or only slightly developed lamella; the other distinguishing characters given for $V$. costellifera are also not very good. $\mathbf{H}$. A. PILsbry, ${ }^{1}$ under the name of $\mathrm{Ch}$. hizenensis, has described a very closely allied form from Japan.

\section{Chione (Omphaloclathrum) subnodulosa, Hanl.}

$$
\text { [']. V, Fig. 5). }
$$

Venus subnodulosa, Hanler; Proc. Zool. Soc. London, XII, 1844, p. 160.

- _ _ Catalogue of rec. biv. shells, p. 360, pl. 16, fig. 19.

Chione - - Deshayes, Catalogue of the Conchifera in Brit. Mus., I, 1853, p. 143.

Venus - - Reeve, Conchol. jcon., XIV, Venus, Sp. 102.

Off Koh Kam, 10 fathoms, gravel $(2 / 2)$. Between Kolı Mesan and Cape Liant, 5-9 fathoms (8). Gulf of Rayong, 7-10 fathoms, sand, mud (13). S. of Koh Samit, 20 fathoms, mud (21). Off Tung Kaben, 6 fathoms, mud mixed with sand (2). S. of Koh Mak, 5-6 fathoms ( $\left.{ }^{1 / 2}\right)$. N. of Koh Kahdat, 4-5 fathoms, coarse sand (8). Koh Kahdat, $1-5$ fathoms, sand (5). Between Koh Kut and Koh Kahdat, 6-10 fathoms, shells, and clay mixed with sand (25). W. of Koh Kut, 15 fathoms, mud (4). W. of Koh Kut, 30 fathoms, sand, mud $(1 / 2)$.

Long. 3-19 $\mathrm{mm}$.

Long. $19 \mathrm{~mm}$, alt. $13 \mathrm{~mm}$, crass. $10 \mathrm{~mm}$.

Distribution:- Singapore (2-3 fathoms, coral-reef ( $/ 2)$, Danish Exp. to Siam), Philippines (Hanley), Thursday Island (v. Mantens), 'Torres Strail (Melvil d Standen), Mast Head Reef, Queensland (Hedley).

This species varies rather considerably, e.g. with regard to the distances between the concentric lamella. The coloration is also, as in Ch. recognita, Sm., very variable; usually the primary colour is light or yellowish, with brown rays or stripes; in the Gulf of Siam, however, entirely white specimens, with dark brown lunules, were taken. The interior of the valves is either quite white or ornamented with dark spots and rays.

1 Proceed. Acad. Nat. Hist. Philadelphia, vol. 56, 1904, p. 553, pl. 41, figs. 1-2. 


\section{Chione (Timoclea) imbricata, Sow.}

Fenus inbricata, Sowenny, Thesaurus Conchyl., 1I, 1855, p. 715, pl.156, figs, 81 - 82.

\begin{tabular}{|c|c|c|c|}
\hline - & - & - & ReEve, Conchol. icon., XIV, Venus, Sp. 118. \\
\hline Chione & - & - & lRöMER, Malakozool. Blätter, XIV, 1867, p. 59, No. 46. \\
\hline Venus & - & - & Fischer, Catalogue d. Moll. de l'Indo-Chine, p. 273. \\
\hline - & Cochinensis, & & Thesaurus Conchyl., II, 1855 , p. 716, pl. 156 , figs. $79-80$. \\
\hline
\end{tabular}

"Gulf of Siam" (L. MorLET).

Distribution: -- Mergui Archip., Ceylon, Red Sea (?). - Cochin China, China, Philippines.

This species does not oceur in the collections made by the Danish Expedition.

\section{Chione (Timoclea) scabra, Hanl.}

Venus scabra, Hanley, Proc. Zool. Soc. London, XII, 1844, p. 161. - Catal. of rec. biv. shells. Append., p.. 361 , pl. 16, fig. 24.

- - - Sowenby, Thesaurus Conchyl., II, 1855, p. 718, No. 45, pl. 157, figs. 101-2.

Venus - - ReEve, Conchol. icon., XIV, Venus, Sp.97.

Chione - - Rö̀er, Malakozool. Blãtter, XIV, 1867, p. 58.

Venus (Chione) scabra, HANLEY, EDG. Smith, Rep. on the Lamellibranchiata of the Challenger Exped., p. 124.

Dautzenieng et Fischer, Journ. de Conchyl., vol.54, 1906, p. 217.

Chione scabru, Hanlex, Melubll d Standex, Proc. Zool. Soc. Iondon, 1906, p. 835.

- micra, Pilsbry, Proceed. Acad. Nat. Hist. Philadelphia, vol. 56, 1904, p.552, pl. 41, figs. 4-5.

Very common; many specimens were taken everywhere between Koh si Chang and Koh Kong, in 3-20 fathoms, on a muddy and clayey bottom.

Long. $2-16 \mathrm{~mm}$.

Distribution: - Poulo Penang ("Galathea" Exped.), Mergui Archip., Gulf of Manaar, Madras, Persian Gulf, Gulf of Oman. - Annam, Philippines, Japan, Mast Head Reef (Queensland).

The present species varies considerably both in outline and in sculpture. Thus, Ch. micra, Pilsbry, is only a younger individual with fewer ribs; several specimens of similar forms (showing even transitional stages to the type-form) are at hand from the Gulf of Siam.

\section{Chione (Timoclea) Siamensis 11. sp.}

$$
\text { (PI. V, Figs. 6-7) }
$$

This species is roundly trigonal, moderately convex, whitish, longer than high, and the posterior end is elongated and rather pointed. The umbo is situated in the anterior half of the valve and the ventral margin is slightly convex. The sculpture consists of strong, parallel, concentric ridges crossed by close-set radiating ridges, and at the points of contact rounded, bead-like granules are formed. These madiating ribs differ in thickness and are placed at different distances apart; thus at the anterior end there are 3-4 strong and prominent ribs, then follow, over the 
whole of the middle portion, numerous close-set, fine, regularly-arranged ribs, which fork towards the ventral margin; then, towards the posterior end, $6-9$ strong ribs occur, which are less broad than the interstices between them; where these posterior radiating ribs meet the concentric ribs, the bead-like granules which occur upon the rest of the shell become strong scales. On the somewhat elongated lunule only slightly granulated, radiating ribs are found; the large oblong area is quite smooth, without any ribs. The interior of the valves is white and somewhat glossy. There are three teeth in each ralve, the central one in the left valve and the central and posterior in the right are tripartite at the top; the posterior tooth in the left valve is only slightly developed. The inner margin is finely crenulated all the way round, but most strongly at the ventral margin, and most finely and closely at the lunule-margin. The pallial sinus is short.

Long. $8 \mathrm{~mm}$, alt. $6 \mathrm{~mm}$., crass. $4.5 \mathrm{~mm}$.

West of Koh Kut, 30 fathoms, sand and mud (6/2).

This new species is most nearly allied to Ch.lionata, Smith, from which it is, however, easily dislinguished by its peculiar sculpture.

\section{Chione (Timoclea) lionata, E. Sm.}

(Pl. V, Figs. 8-10).

Venus (Chione) lionata, EDG. Smin, Report on the Lamellibranchiata of the Challenger Exped., 1885, p. 126, pl. 3, fig. 7 .

Between Koh Rin and Cliff Rock, 15 fathoms ( $/ / 2)$. Koh Kram, 30 fathoms (2/2). Off Koh Kam, 10 fathoms, gravel (1/2). E. of Cape Liant, 9 fathoms, shells $(1 / 2)$. S. of Kol Samit, 20 fathoms, mud (1/2). S. of Koh Chuen, 30 fathoms, shells (15). Between Kol Chuen and Koh Chang, 15 fathoms, mud $(3 / 2)$. S. of Koh Kahdat, 8-10 fathoms, mud ( $(1 / 2)$. Between Koh Kut and Koh Kahdat, 10 fathoms, shells (17). S. of Koh Kut, 17-20 fathoms, mud ( $\left.{ }^{4 / 2}\right)$. W. of Koh Kut, 15 fathoms, mud ( $\left./ 2\right)$. Long. $8 \mathrm{~mm}$., alt. $6.5 \mathrm{~mm}$, crass. $5 \mathrm{~mm}$.

Distribution:- Singapore, shallow water (Danish Exp. to Siam). - Anboina, S. of New Guinea (Challenger).

I have compared my specimens with Eog. Smon's original types in the British Museum; they exactly agree with his specimen from Amboina (which he regards as a variety), while his specimens from New Guinea are somewhat dillerent. Judging from the large quantity of material at hand from the Gulf of Siam it appears, however, that the species varies considerably. As may be seen from the measurements given above, the specimens from the Gulf of Siam are larger than Suru's from the Challenger Expedition. As Swiru's figure is not very good I lave here given a new figure.

Chione (Antigona) lamellaris, Schumacher.

Antigona lamellaris, Scuusache1, Essai d'un nouv. systime d. habitat. d. vers testacés, 1817, p. 155, pl. 14, fig. 2.

Venus - - - Mantivi u. Chemsirz, Conchyl. Cabin., XI, 1 Abth., p. 142, pl.8, tigs. $10-11$. 
Venus (Anligona) lamellaris, Schumank, Evg. Suтr, Rep. on the Lamellibranchiata of the Challenger lixp., p. 121.

- lamellaris, Schumagher, Crosse et Fiscuen, Journ. de Conchyl., vol. 40, 1892, p. 76.

Dosina Lamarckii, Giay, The Analyst, VIII, 1838, p. 308.

Chione - - Römer, Malakozoolog. Blätter, XIV, 1867, p. 39.

Tenus - - - ReEve, Conchol. icon., XIV, Tenus, Sp. 39.

Sowerby, Thesaurus Conchyl., II, p. 707, pl. 153, figs. 20-21.

nodulosa, Sowerby jun., Thesaurus Conchyl., II, p. 708, pl. 153, fig. 16.

- cancellala var., Cuemsitz, Conchyl. Cabin., VI, 1782, p.310, p. 29, figs. 306-7.

S. of Koh Chuen, 30 fathoms, shells (3). E. of Cape Liant, 9 fathoms, shells (2). Gulf of Rayong, 7-10 fathoms, mud (5). W. of Koh Kut, 15 fathoms, mud (1).

Long. $11-40 \mathrm{~mm}$.

'The Gulf of Siam, west coast of Cambodge (PAviE).

Distribution:- Singapore, Tranquebar, Ceylon and Gulf of Manaar, Aden (Shopland). - Philippines, China, Japan, North, East and West Australia (Brazier), Viti Isls.

\section{Chione reticulata $L$.}

Venus reticulata, Linné, Syst. Nat., ed. X, 1758, p. 687, No. 110. - ed. XII, p. 1133, No. 134. - Mus. Ludov. Ulrica reg., 1764, p. 503, No. 64.

Chemnitz, Concliyl. Cabin., VI, p. 367, pl. 36, figs. $382-83$.

- - _ Sowerer, Thesaur. Conchyl., 1I, p. 706, pl. 153, figs. 11-13.

- - REeve, Conchol. icon., XIV, Venus, Sp. 34.

- - - Martini u. Chemitz, Conchyl. Cabin., XI Bd., 1 Abth., p. 143, No. 15, pl. 10,

Chione - - Rösen, Malakozoolog. Blätter, XIV, 1867, p. 36, No. 12.

V'ents (Antigona) reticulata, LINNÉ, E. v. MAlRTEx, The Journal of the Linnean Soc., Zoology, vol. 21, 1887. p. 212.

- corbis, Lamarck, Hist. nat. d. anim. s. vert., V, 1818, p. 585, No.4. - ed. 2, VI, p. 337, No.4.

- Morlet, Journ. de Conchyl., vol. 37, 1889, p. 170, No. 68.

- Fiscuer, Catalogue d. Moll. de l'Indo-Chine, p. 233.

- reticulata, Linxé, R. Bulden Newton, The Geological Magazine, New Ser., Dec. IV, vol. 7 , 1900, p. 553, pl. 21, fig. 2 .

Islands in the Gulf of Siam (L. MorLET, Ioc. cit.).

Distribution:- Mergui Archip., Nicobars, Ceylon, Addu Atoll and Hululu Isl. (Maldive Archip.), Persian Gulf, Aden, Red Sea, Madagascar. - Philippines, dapan, Moluccas, Torres Strait, New Caledonia, Marianne Isls., Lifu, Viti Isls., Society Isls., Marquesas Isls., Paumotu Isl.

Strangely enough, the Danish Expedition to Siam collected no specimens of this species.

\section{Chione (Circomphalus) calophylla, Phil.}

Venus calophylla, I’Hilipp, Archiv f. Naturgeschichte lisg. v. Wiegmann, II Jahrg., 1 Bd., 1836, p. 229, pl. V11l, fig. 2.

- calophyla, Haxley, Sowerbr, Thesaurus Conchyliorum, 11, 1855, p. 724, pl. 160, fig. 176.

- calophylla, PHurpi, Revek, Conchol. icon., XIV, Venus, Sp. 114.

- - - Martini u. Chennitz, Conchyl. Cabin., XI, 1 Abth., p. 208, pl. 33, figs. $13-15$.

- (Chione) calophylla, PhilpP, Evg. S.uth, Lamellibranchiata of the Challenger Exped., 1. 122.

Anailis calophylla, PHupp!, Hidicgo, Obras malacológicas, I, tom. II, 1903, p. 294, No. 387. 
S. of Koh Samit, 20 fathoms, mud (1). W. of Kol Chuen, soft clay and mud $\left({ }^{3} / 2\right)$. Between Koh Chuen and Koh Chang, 15 fathoms, mud (1). N. and W. of Koh Chang, 10-20 fathoms, mud (6). S. of Koh Bidang, 9 fathoms, mud (4). Between Koh Kahdat and Koh Kut, 6-10 fathoms, mud, clay mixed with sand, and shells (12). S. and W. of Koh Kut, 15-20 fathoms, mud (9).

Long. 2-36 $\mathrm{mm}$.

Distribution:- Singapore (Danish Exp. to Siam: one specimen in 2-3 fathoms; Sv. GaD: 5 specimens in shallow water), Mergui-Archip., Andamans, Madras, Gulf of Manaar. - Philippines, China, Japan, Thursday Isl. (SEnon), New Guinea, Torres Str., North Australia, Sydney.

Note. The Danish Expedition to Siam obtained two specimens, and Mr. Sv. GaD several specimens of Chione (Circomphalus) foliacea, Phil., at Singapore.

Chione (Circomphalus) isabellina, Phil.

Venus isabellina, PHumpr, Zeitschr. f. Malakozoologie, V, 1St8, p. 188 (it is due to a misprint, which is corrected in the register, that this species is called isabillnia).

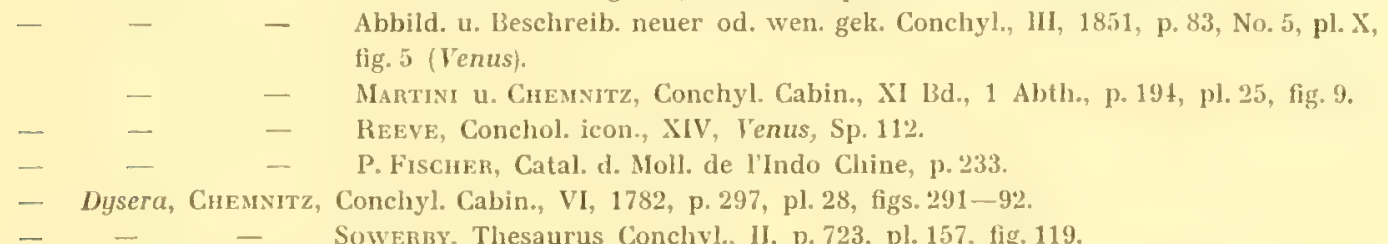

- - - Soweriz, Thesaurus Conchyl., II, p. 723, pl.157, fig. 119.

Anaitis isabellina, PHilipp1, Hidalgo, Obras malacologicas, 1, tom. 1I, 1903, p. 291, No. 38 .

The strand off the Mangrove at the station on Kol Chang, very shallow water (4). 'The coast of Lem Ngob (2).

Long. $16-26 \mathrm{~mm}$.

Distribution: - Bombay. - Annam, China, Japan, Philippines, Port Curtis, Sydney (W.Denison, Madras Museum).

Melvill \& Standen say regarding this species:" "Perhaps best treated as a variety of A. foliacea" (Anaitis, foliacea, Philippi).

\section{Chione (Ventricola) toreuma, Gould.}

Venus torenma, Gould, Proceed. of the Boston Soc. Nat. Hist., III, 1850, p. 277. - Otia Conchologica, p. 84.

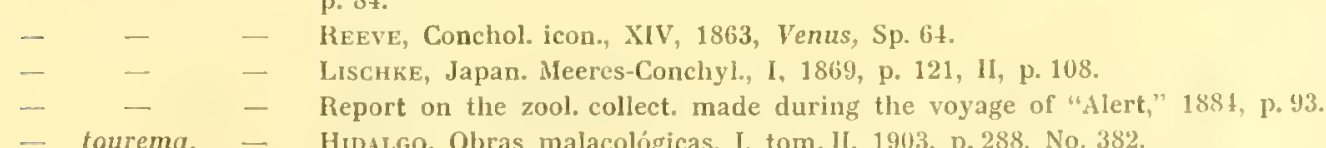

- tourema, - Hidalgo, Obras malacológicas, I, tom. II, 1903, p. 288, No. 382.

- Jukesi, Deshayes, Catalogue of the Conchifera in the Coll. of the British Mus., I, 1853, p. 100, No. 3.

- - - Martini u. Chesinitz, Conchyl, Cabin., XI, 1 Abth., p. 217, pl. 35, figs. 7--9.

Chione (Ventricola) Jukesi, Deshayes, Rösen, Malakozool. Blätter, XIV, 1867, p. 123.

Venus crebrisulca, Sowerby, Thesaurus Conchyl., 11, 1855, p. 728, pl. 161, figs. 187 -89 (non Lasarck).

- sculpta, Deshayes, Reeve, Conchol. icon., loc. cit., Sp. 5 (fide Edg. Smith).

: Proc. Zool. Soc. London, 1906, p. 834. 
Koh Kram, 30 fathoms (1/3). North side of Koh Mesan, 10-15 fathoms, stones (2). Koh Chuen, 10-15 fathoms $(1 / 2)$.

Long. $10-29 \mathrm{~mm}$.

Distribution:- Ceylon and Gulf of Manaar, Hululu Isl. (Maldive Archip.). - Philippines, Japan, Torres Strait, North and East Australia, Funafuti (Ellice Isls.), Mangsi Isl., Sooloo-Sea.

The present species is recorded (with doubt) from Mauritius and Cargados, and probably erroneously by J.G. Coopen from California.

I doubt whether Chione embrithes, Mervilu and Staninen, ${ }^{1}$ can be maintained as a distinct species.

\section{Dosinia trigona, Reeve.}

Artemis trigona, RErie, Conchol. icon., VI, 1850, Artemis, Sp. 42..

Cytherea - - SowlinuY, Thesaurus Conchyl., II, p. 633, pl. 133, fig. 120.

Artemis - - - loc. cit., II, p. 659, pl. 141, fig. 20.

Dosinia - - Römer, Monographie d. Molluskengatt. Dosinia, 1862, p. 20, pl. 4, fig. 5.

The strand off the Mangrove at the station on Kol Chang (2). Coast of Lem Ngob $(3 / 2)$.

Long. $20-39 \mathrm{~mm}$.

Long. $35 \mathrm{~mm}$, alt. $37 \mathrm{~mm}$, crass. $27 \mathrm{~mm}$.

- $31 \mathrm{~mm}$, - $32 \mathrm{~mm}$., - $20 \mathrm{~mm}$.

Distribution:-- Gulf of Manaar ('THurston).

ReEve's statement (repeated by Deshayes, Sowerizy, Römer and others) that this species was found in the Red Sea has not hitherto been confirmed.

\section{Dosinia laminata, Reeve.}

Artemis laminata, REEVE, Conchol. icon., VI, 1850, Artemis, Sp. 41.

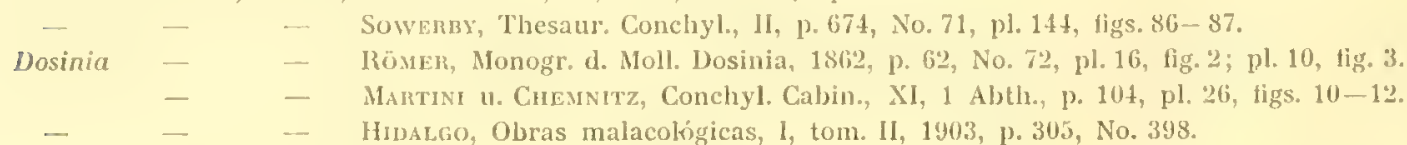

Off Tung Kaben, 6 fathoms, mud mixed with clay (1). W. of Koh Chang, 20 fathoms, mud (2). S. of Koh Kahdat, 8-10 fathoms, mud (5). Koh Kahdat, 1-5 fathoms, sand (1). Between Koh Kut and Koh Kahdat, 6-10 fathoms, clay and sand $(2+\%)$. S. of Koh Mak, 5-6 fathoms (1). East of Koh Mak, 20 fathoms, mud $(3+1 / 3)$. W. of Koh Kut, 15 fathoms, mud (20).

Long. 1/z-34 mm. (Long. $34 \mathrm{~mm}$, alt. $34 \mathrm{~mm}$. , crass. $18 \mathrm{~mm}$.).

Distribution:- Andamans, Red Sea (pleistocene). - Philippines, China, Japan.

Almost all the individuals from the Gulf of Siam were full of clay between the transverse ribs owing to the clayey soil in which they had been living.

1 Journal of the Limean Society, Zoology, vol. XxVII, 13. 195. 


\section{Dosinia exasperata, Phil.}

Cytherea (Artemis) exasperata, PHulppr, Abhild. u. I3eschreib. neuer od. wen. gek. Conchyl., III, 1847, p. 24 (36), pl. 8, fig. 4 .

Artemis exasperata, Philippl, Soverry, Thesaur. Conchyl., II, p. 670, No. 55. pl. 143, fig. 62.

$\begin{array}{cccc}- & - & - & \text { ReEve, Concliol. icon., VI, Artemis, Sp. 21. } \\ \text { Dosinia } & - & - & \text { Hidalgo, Obras malacológicas, I, tom. II, 1903, p. 311, No. } 407 .\end{array}$

The sound of Koh Chang, 5 fathoms, soft clay (5/2). W. of Koh Kut, 15--30 fathoms, mud $(2 / 3)$.

Long. 8-30 mm.

Distribution: - Coromandel Coast (?), Karachi, Mekran Coast. -- Philippines.

Several authors have connected Dosinia prostrala with the present species; but, as far as I can see, the two species have nothing to do with each other. In the Zoological Museum of the University of Copenhagen SPEvgLER's specimen of Dos. prostrata L. is labelled: "Venus prostrata Lin. Sp. 137. Chemn. Tom.6, fig. 298, Tranquebar." It exactly agrees with the figures in Hanler's Ipsa Linnæi Conchyl., Pl. 1, Fig. 7; in Encyclop. méthod., Pl. 277, Fig. 1; in ReEve, Conchol. icon., Sp. 23; in Hancey, Monogr. (Sowerby, Thes. Conchyl.), Pl. 144, Fig. 80, and with the description in Chemertz, Conchyl. Cabin., VI, p. 302. It may probably be assumed that Spenglen's specimen is correctly determined, at any rate it undoubtedly corresponds with Chemnitz's view of prostrata; but Spenglen's prostrata and Philippi's exasperata differ widely, the outline in prostrata being angular, which (especially in full-grown individuals) gives a squarish appearance to the shell; this is compressed (like Circe scripta L.), and the lunule is elongated: while in Dos. exasperata the outline is almost circular, the shell is more arched, and the lunule is smaller and cordate; and as regards the sculpture, the transverse ribs are more close-set and much finer. Dosinia exasperata, Phil., should therefore be regarded as a distinct, well-characterized species. Römen's Dos. prostrata L. is certainly not Spengler's (Chemntz's) species of that name; the latter Römer has determined as Dos. Bruguieri, Gray.

\section{Dosinia dilecta, A. Ad. \\ (Pl. V, Figs. 11-13).}

Dosinia dilecta, A. Adaus, Proc. Zool. Soc. London, 1855, p. 224, No. 15.

Römer, Monogr. d. Molluskengatt. Dosinia, 1862, p. 66, No. 77.

The sound of Koh Chang, 5 fathoms, soft clay ( $\left.1^{1 / 2}\right)$.

Long. $40 \mathrm{~mm}$., alt. $41 \mathrm{~mm}$., crass. $21 \mathrm{~mm}$.

1 The figure on P1. 29, Fig. 298 is not good, and does not agrec with the description; the phrase "testa orbiculari valde compressa et complanata" suits the figure lut badly; so also the synonyms given by Chemsitz unquestionably do not all refer to this form; how far on the whole LinNe and CHEMnitz have had the same form before them I am not prepared to say.

- Spengler and Chemsitz were in daily communication with each other; see Malakozool. 13läter, XVII, 1870, p. 99.

13. K. D. Vidensk. Selsk. skr., 7, Raklke, naturvidensk, og mathem. Afit. V. 3. 
Distribution:- Malacca (Dr. 'Tralli), Pulo Bidang, N. of Penang (Sreat, Brit. Mus.).

On the label of the specimens of $D$. dilecta, A. Ad., in the British Museum, D. striatissima, Sowerby, is given as a synonym; I very much doubt whether this is correct, as Sowerby in "Thesaurus Conchyliorum" (p.673) refers his species to "Sect. 6: Edge of the dorsal area raised above the circumscribing line," a feature which is not to be found at all in D. dilecta, A. Ad.

\section{Dosinia cretacea, Reeve.}

Arlemis cretacea, Rervi, Conchol. icon., VI, 1850, Artemis, Sp. 35.

- _ _ Soweray, Thesaur. Conchyl., II, p. 667, No. 46, pl. 142, fig. 51.

Dosinia - - Röser, Monogr. d. Moll. Dosinia, 1862, p. 34, No. 32, pl.6, fig. 8.

L. Morker, Journ. de Conchyl., vol. 37, p. 169.

Hrdago, Obras malacológicas, I, tom. II, 1903, p. 304, No. 402.

"Iles du golfe de Siam" (I. Monlet).

Distribution: - Persian Gulf (v. Martens), Red Sea (P'. Fischer, ${ }^{1}$ Sturany $\left.{ }^{2}\right)$. - Annam, Philippines.

The Danish Expedition to Siam brought home no specimens of this species.

Dosinia Hanleyana, H.\&A. Ad.

Dosinia simplex, A. Adams, Proc. Zool. Soc. London, 1855, p. 224, No. 14 inon Artemis simplex, Han'ey, Proc. Zool. Soc., 1845, p. 11 .

- - Hömer, Monogr. d. Gatt. Dosinia, 1862, p. 75, No. 90.

- Hanleyana, H. \& A. Adams, The Genera of recent Mollusca, II, 1858, 1. 431.

Singaporensis, - MS., British Museum.

The strand off the Mangrove at the station on Koh Chang (1).

Long. $8.5 \mathrm{~mm}$, alt. $8 \mathrm{~mm}$, crass. $4 \mathrm{~mm}$.

Distribution:- Singapore (Cumng).

By comparisons in the British Museum I have convinced myself that the small specimen from the Gulf of Siam corresponds with ADAMs's species Singaporensis; Mr. EDG. Smrtr kindly tells me that that species is identical with simplex, A. Ad., a name which H. and A. ADAus afterwards altered to Hanleyana, owing to its having previously been used by HAxLEY.

\section{Dosinia contusa, Reeve.}

Artemis contusa, RErve, Conchol. icon., VI, 1850, Artemis, Sp. 38.

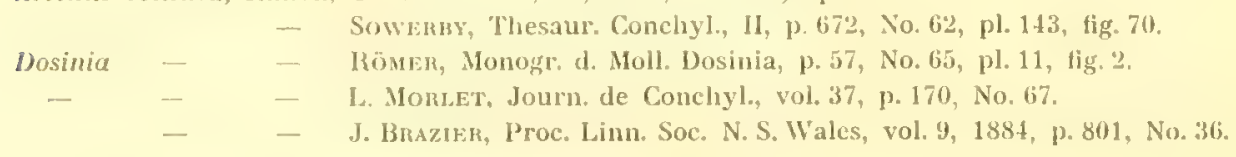

1 Catalogue d. Moll. de I'Indo-Chine, p. 231.

: Nachrichtshlatt d. Deutschen Malakozool. (iesellsch., 1905, 138. 
"Iles du golfe de Siam" (L. Moriet).

Distribution:- New Guinea, North and North-west Australia.

This species does not occur among the material brought home by the Danish Expedition to Siam, and Dautzenberg and Fischer think ${ }^{1}$ that probably it is Dosinia Gruneri, Phil., which Mortet records from the Islands in the Gulf of Siam under the name of $D$. contusa, Reeve.

\section{Dosinia pubescens, Phil.}

Cytherea (Artemis) pubescens, PHilpp, Abbild. u. Beschreib. neuer od. wenig gekannt. Conchyl., 111, 1847 (1851), p. 24 (36), pl. 8, fig. 3.

Artemis pubescens, Philipi, Sowerix, Thesaurus Conchyl., II, p.672, No.64, pl. 143, fig. 72.

Dosinia - - Römer, Monogr. d. Moll. Dosinia, p. 79, No. 96, pl. 15, fig. 1.

Koh Kahdat, 1-5 fathoms, sand (1). North of Koh Kahdat, 4-5 fathoms, coarse sand (1/2). Koh Mak, sandy coast (1/2). West of Koh Kut, 30 fathoms, sand and mud $(1 / 2)$.

Long. 5-20 $\mathrm{mm}$.

Distribution:- Bombay, Mekran Coast, Aden, Madagascar, Durban. Philippines, Labuan (N. Borneo), New Holland.

All the specimens from the Gulf of Siam are young, and the lamella which limit the convex area are therefore not so well-developed as in oider individuals. In one of the specimens from Koh Kahdal the apices are red and the umbones are ornamented with reddish-brown zig-zag lines and spots. Melvilu and ABEnCROMBIE" say also "Young specimens are nearly circular", silky in appearance and often linged with pink." EDG. Surti" unites with this species the following:D. scabriuscula, Reeve (? of Philippi), D. ovalis, Römer, D. eunice, A. Adams, and D. bisecta, Reeve (?) (i. e. biscocta, Reeve), the last species is recorded from Japan.

\section{Cyclina elegans, H. Ad.}

(Pl. V, Figs. 14-15).

Lucina elegans, H. AnAMs, Proc. Zool. Soc. London, 1870, p. 791.

Gulf of Rayong, 7-10 fathoms, sand, mud, shells (2).

Long. $7 \mathrm{~mm}$., alt. $7 \mathrm{~mm}$., crass. $5 \mathrm{~mm}$.

Distribution:- Red Sea (M'ANDrEw).

By examining H. ADAms's original specimens in the British Museum I have convinced myself that my specimens from the Gulf of Siam are identical with Lucina elegans, H.Adams." It is, however, incorrect when ADAss refers that species to the genus Lacina, it being a Cyclina; as his diagnosis is deficient and also partially misleading, I give here a description and figures of my individuals:- Valves

1 Journal de Conchyliologie, vol. 54, 1906, p. 216.

"Memoirs and Proceed. of the Manchester Lit. and Phil. Soc., 4 Ser., vol. 7, p. 45.

s Proc. Zool. Soc. London, 1891, p. 421.

4 Mr. EDG. A. SMith has kindly verified my determination. 
circular, convex, white, rather thin; umbones high and situated at the middle of the axis of the shell. Apex turning towards the anterior end. 'The whole surface covered with a network of close-set, fine, parallel lines, which cross each other: they proceed from the umbones and from the upper sides and radiate outwards towards both ends and towards the ventral side. Upon each valve there is a large, elongated, crescent-formed lunule, circumscribed by a groove; it is glossy, destitute of network sculpture, and striped only by the lines of growth; the brown ligament is external. The interior of the valves is glossy, milky white; in the right valve there are two diverging cardinal teeth of which the posterior is bifid; in the left valve there are three cardinal teeth of which the central and largest is bifid. 'The margin is smooth. The sinus is high and widely triangular.

Note. Clementia papyracea, Gray, has been taken at Singapore in shallow water (by Sv. GaD).

\section{Venerupis Irus L.}

Donax Irus, Linne, Syst. Nat., ed. XII, 1767, p. 1128, No. 111.

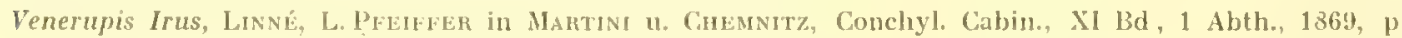
245 , pl. 31 , figs. $17-19$.

- irus, -... Bucuuor, Dautzenizha et Dollfus, Moll. mar. de Roussillon, 1I. p. 438, pl. 67, tigs. 9-18.

- macrophylla, Deshayes, Catal. of the Conchifera in the coll. of the I3ritish Museum, I, 1853,

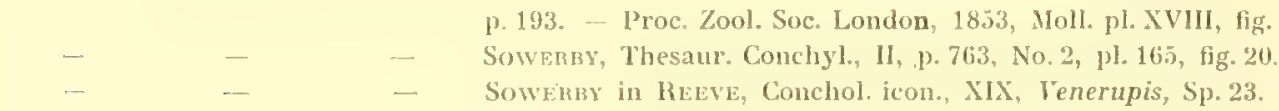

Rupellaria - - Pagexstecinen, Ueber d. v. Kossmann am Rothen Meere ges. Moll. 1877, p. 12, No. 35 .

- Rochemune, Matér, pour la faune de l'Archipel du Cap Vert. Nouv.

Venerupis

Irus

Venerupis

$\begin{array}{lc} & \text { derelicta, } \\ - & - \\ - & - \\ - & \text { fimbriata, Sowrim } \\ & \text { atlenuata, }\end{array}$

Arch. du Muséum, 2 Sẻr., Mémoires, IV, p. 255, No. 34.

- A. H. Cooke, Ann, and Mag. Nat. Hist., 1886, p. 103.

- Melvill and Standex, Journ. of Conchol, IX, p. 84.

- Hroalgo, Fauna malacol de 1. IsI. Filipin., II, p. 321, No. 417.

-. Proc. Zool. Soc. London, 1853, p. 4, No. 17.

- Sowerby. Thesaur. Conchyl., 1I, p. 765, No.9, pl. 164, fig. 16.

- - in Rever. Conchol. icon., XIX, Venerupis, Sp.8.

IInalgo, Fauna malacol. de 1. Isl. Filipin., 11, p. 320, No. 415

", Thesaur. Conchyl., II, 1855, p. 766, No. 12, pl. 165, fig. 23.

in REkYE, Conchol. icon., XIX, Tenerupis, Sp. 25.

REEVs, Conchol. icon., XIX, Venerupis, Sp. 7.

Koh Mesan, 15 fathoms, stones (2/2). Between Koh Mesan and Cape Liant, 5-9 fathoms, sand ( $/ / 2)$. Coast of Lem Ngob, low tide, stones ( $3 / 2)$. North end of Koh Chang, 1 fathom, coral blocks (1). Koh Chang, 1-2 fathoms, old coral blocks (6). Kioh Kahdat (2/2).

Long. 1-14 $\mathrm{mm}$.

Distribution: - Singapore (shallow water, Sv, GaD), Madras, Bombay, Persian Gulf, Karachi, Aden, Red Sea, Suez, Mediterranean, Black Sea, Atlantic Ocean (the coast of Europe from England and Ireland to Cape Vert), Mauritius. - Annam (V. altenuata, Sow.), Philippines, Japan, Aru Isl. (V. altenuata, Sow.), Funafuti Atoll. 
It is not possible for me to distinguish between specimens from the Gulf of Siam and European individuals, e. g. from the Mediterranean. Besides the synonyms above enumerated several more can undoubtedly be added, thus, e. g. V. semipurpurea, Dunk., ${ }^{1}$ mitis, Desh., " planicosta, Desh., etc.

\section{Fam. Petricolidae.}

\section{Naranio lapicida, Chemn.}

Venus Lapicida, Chemsitz, Conchyl. Cabin., X, 1788, p. 356, pl. 172, figs, 16iti-6i.

- - - Guelix, Syst. Nat., ed. XIII, p. 3269 , No. 148

Naranio lapicida, - DESHAves, Catalogue of the Conchifera in the coll. of the 13rit. Mus., 1, 1853,

1). 216 , No. 2.

Petricola - _ Sowerix, Thesaur. Conchyl., 11, 1855, p. 776, No. 20, pl. 166, fig. 26.

KinEns, West-Ind mar. shells, 1864, p. 108.

Soweriy in Reeve, Conchol. icon., XIX, Petricola, Sp. 24.

EDG. SMith in Zoolog. Collect. of H. M. S. dlert, 1884, p. 98, No. 22.

Choristodon lapicidum, Chemnitz, Pritchand and GatlifF, Proceed. Roy. Soc. Victoria, vol. 16, 1903, p. 121:

Venus divaricata, Chemsitz, Conchyl. Cabin., X, 1788, p. 357, pl. 172, figs. 1666-67.

Petricola -- D'Orbigny, Mollusques de l'ile de Cuba, II, 1853, p. 265, No. 463.

Naranio - Chemnitz, Deshares, Catal. Conchif. Brit. Mus., I, 1853, p.216, No. 1.

Petricola - - Sowerby, Thesaur. Conchyl., II, p. 776, No. 19, pl. 166, figs. $24-25$.

- - Deshajes, Mabille et Le Mesle, Journ. de Conchyl., vol. 14, 1866, p. 117.

- - Chemnitz, v. Mantexs in v. d. Deckev's Reisen in Ost-Afrika, III, 1869, p. 66, pl. 3 , fig. 3.

-.. - - Sowerry in Reeve, Conchol. icon., XIX, Petricola, Sp. 22.

Choristodon divaricatum, Chemitz, H. \& A. Adams, Genera of rec. Moll., II, 1858, p. 442, pl. 110, fig. 2.

Venus divergens, Gielis, Syst. Nat, ed. XIII, 1790, p. 3269, No. 147.

Petricola costata, LłMarck, Systême d. anim. s. vert., 1802, p. 121.

Naranio - - Gray, Ann. and Mag. Nat. Hist., 1853, XI, p. 38.

Petricola lucinalis, - Hist. nat. d. anim. s. vert., V, 1818, p. 501, No. 4. - éd. 2, VI, p.157, No.4.

Koh Chang, 1 fathom, old coral blocks (12). Koh Kahdat, 1 fathom, sand (1). Long. $7-23 \mathrm{~mm}$.

Distribution:- Gulf of Manaar, Maldive Archip., Persian Gulf, Gulf of Oman, Aden, Red Sea, Mauritius, Zanzibar, Mozambique, Querimba Isls. - Poulo Condor, Aru Isl., Torres Strait, Mast Head Reef (Queensland), St. Vincent's Gulf (South Australia), Victoria, Yap, Pelew Isls., Funafuti Atoll. -- East coast of America: Florida, Greater and Lesser Antilles (to Martinique, DALL).

\section{Fam. Cardiidae.}

Cardium (Acanthocardium) setosum, Redf.

Cardium setosum, Repfield, Ann. Lyceum Nat. Hist. New York, IV, (1846) 1848, p. 168, pl. XI, fig. 1. EDg. Swru, Rep. Challenger Lamellibranchiata, 1885, [p. 158.

¿ Dunker, Index moll. mar. Japon., p. 208. - I'ItSbry, Catal. of the Mar. Moll. of Japan, 1895, p. 129.

2 Taken at Botany Bay (ANGAS) and Tasmania (TATE \& MAY).

${ }^{3}$ That V. Irus may also occur ornamented with vivid colours has been stated by DAUTZENBERG (loc. cit. p. 443) and PAliany (Journ. de Conchyl., 1900, pp.403-4); it then recalls V. exotica, Hanl. 
Cardium selosum, Rivifeld, Hrdalio, Obras malacológicas, I, tom.11, 1903, p.329, No.428.

lalum, Chemnitz, Conchyl. Cabin., VI, 1782, p. 197, pl. 19, figs. $192-93$.

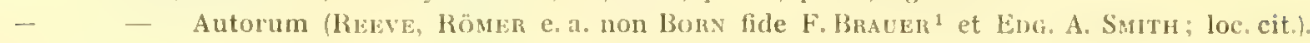

Islands in the Gulf of Siam (L. MorLeT, Journ. de Conchyliologie, vol. 37, 1889, p. 168).

The Danish Expedition to Siam collected no specimens of this species.

Distribution:- Mergui Isls., Nicobars, Madras, Ceylon, Bombay, Persian Gulf, Gulf of Aden. - Hong Kong, Philippines, Java, Sulu Isls.

\section{Cardium (Acanthocardium) Sueziense, Iss.}

Cardium Suezicnsis, ISSEL, Malacol. d. Mar Kosso, 1869, p. 76, pl. 3, fig. 4.

- sueziense - Edg. Sмтт, Lamellibranchiata of the Challenger Exped., p. 158, pl. VIII, figs. $2-2$ b.

- fragun, Linné var. sueziense, Issel, Ch. Hedlery, Australian Museum, Sydney. Memoir 111, 1896-. 1900 , p. 504 .

Between Koh Mesan and Cape Liant, 5-9 fathoms, sand (2). Between Koh Riot and Koh Mesan, 3-5 fathoms, sand (12). Koh Kahdat, 1 fathom, sand (2). West of Koh Kut, 15 fathoms, mud (15).

Long. 4-10 $\mathrm{mm}$.

Distribution:- Ceylon, Gulf of Manaar, Angrias Bank, Laccadive and Maldive Archip., Persian Gulf, Mekran Coast, Red Sea (Sturivy), Gulf of Suez (common, ISSEL and I' Andrew). - Torres Strail, Levuka, Viti Isls., 12 fathoms (Challenger), Funafuti (Ellice Isls.).

EDG. A. Smitr (loc. cit. p. 159) is quite right in thinking that the present species may become larger than his specimens $(7 \mathrm{~mm}$.) from the Viti Islands; in the Gulf of Siam they attain, as stated above, $10 \mathrm{~mm}$. ISSEL gives as the maximum for the specimens from the Gulf of Suez $6 \mathrm{~mm}$. STuRany mentions the following measurements for specimens from Massaua: - alt. $7.25 \mathrm{~mm}$., long. $7 \cdot 5 \mathrm{~mm}$, crass. $5.75 \mathrm{~mm}$. Several of the individuals from the Gulf of Siam were ormamented with distinct intercostal sculpture, and both entirely white individuals and also forms with red dots and spots occur; in the latter the red colour is also seen upon the white interior of the valves. Valves are often found which are vivid yellow upon the interior of the umbonal region. CH. HEDLEY (loc. cit.) is of opinion that the species under consideration is a variety of Hemicardium fragum L. Upon the basis of the material collected at Funafuti Atoll (Ellice Isls.) he says: "I'he four dozen odd valves before me exhibit much variation in contour, and they appear to pass by gradual transition into typical C. fragrum," but I doubt whether he is right in this supposition. (I do not understand the reason why HEDLEY always in his paper gives "C. fragrum L." for C. fragum L.).

\footnotetext{
1:. Bna en, Sitzungsber. d. k. k. Akad. d. Wiss. Wien. Mathemat. naturw, Classe, Bd. 77, 1 Abth., p. 127. "Nachrichtsblatt d, Deutsch. Malakozool. Gesellsch., 1905, p. 139.
} 
Cardium (Bucardium) Asiaticum, Brug.

Cardium Asiaticum, Bruguñre, Encyclop. méthod. Vers, Tom. I, 1792, p. 224, No. 19, pl.293, fig. 2.

- - - ReEve, Conchol. icon., II, Cardium, Sp. 90.

Martini u. Chennitz, Conchyl. Cabin., X, "2 Abth., p. 66, pl. 2, figs. 4-5.

[ӟ̈цow, Nachrichtsbl. d. Deutsch. Malakozool, Gesellsch., 1905, p. 81, pl. 2, fig. 7 .

- lima, Spengler, Schröten, Einleit. in d. Conchylienkenntn., III, 1786, 1.. 53.

- - Guelin, Systema Naturae, ed. XIII, p. 3253, No. 30.

- lamellatum, Spengt.er, Skrivter af Naturhistorie Selskabet, V, 1799, p. s.

North of Koh Kam, 5 fathoms, gravel. Koh Chuen, 30 fathoms.

Long. $30-46 \mathrm{~mm}$.

Distribution:- Nicobar Isls, Ceylon and Madras, South Africa (Natal, Port Elisabeth). - China.

DUNKER ${ }^{1}$ undoubtediy erroneously records Guinea as the locality for the present species. SPENGLER's original specimens in the Zoological Museum of the University of Copenhagen are labelled "Card. lamellatum Spengl., Niquebar."

Cardium (Bucardium) coronatum, Spengl.

Cardium coronatum, Spengler, J. S. Schröter, Einleit. in d. Conchylienkenntniss, 1786, III, p. 53, pl. VII (in II Bd.), fig. $13 \mathrm{a}, \mathrm{b}$.

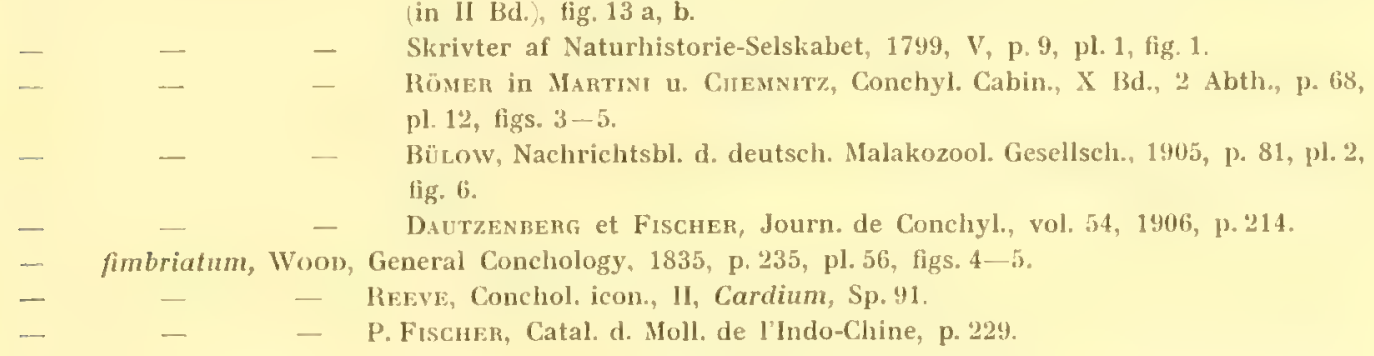

Commonly distributed from Koh Chang to Koh Samit, 3-30 fathoms, clay, mud and sand.

Long. $4-39 \mathrm{~mm}$.

PAvie in 1884 took it at the islands in the Gulf of Siam (Journ. de Conchyl., vol. 37, p. 168).

Distribution:- Mergui Archip. (v. Martens), Bay of Bengal (Madras, Aracan coast), from Goa to Bombay, Karachi. - Annam (Crosse, Fischer, Boutan), China (Hong Kong).

SPEngLen's original specimens in the Zoological Museum of the University of Copenhagen are labelled "aus Niquebar." Melvili. and Standen (Proc. Zool. Soc. London, 1906, p. 838) write: "After detailed examination of many examples in all stages of growth, it is the opinion of Mr. Alexander Ambincombir: that coronatum Spengler is synonymous (with Cardium Asiaticum, Chemn.);" at present I cannot agree with this opinion.

${ }^{1}$ Index molluscor. quae in itinere ad Guineam infer. coll. G. Tams, 1853, p. 50, No. 134. 


\section{Cardium (Bucardium) multispinosum, Sow.}

Cardium multispinosum, G. 13. SowerBr, Proc. Zool. Soc. London, 1840, p. 106.

- Conchol. Illustrations, figs. $38-38$ a.

Refve, Conchol. icon., II, Cardium, Sp. 10.

Mantini u. Chemeitz, Concliyl. Cabin, X Bd., 2 Abth., p. 67, pl. 12, figs. $1-2$.

Bülow. Nachrichtsbl. d. Deutsch. Malakozool. Gesellsch., 1905. p. 81 , pl. 2 , tig. 5.

T'aken in different localities between Koh Chang and Koh Kul, 6-20 fathoms, mud and clay (5).

Long. 21-41 mm.

Distribution:- Mozambique (v. Martens). - Philippines (Cumra, Hidalgo), China (J. ReEves), north and east coasts of Australia (Angas, "Challenger"-Exped., "Alert"-Experd.1.

\section{Cardium (Bucardium) Sinense, Sow.}

Cardium Sinense, G. B. Sowerm, Proc. Zool. Soc. London, 1840, p. 105.

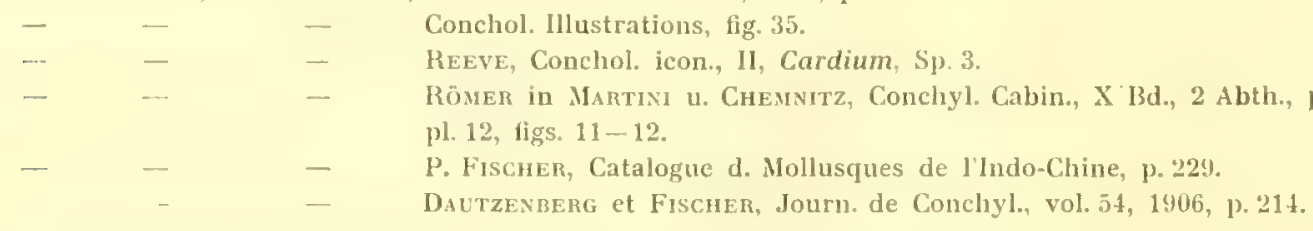

Commonly distribuled from Koh Chuen to Koh Kong in $3-30$ fathoms, mud, clay and shells.

Long. $1-40 \mathrm{~mm}$.

Distribution: - Annam (Crosse el Fischer, Boutan), Hong Kong, China (Sowerby), Philippines (Sowerby, Hidalo), Java (Reeve).

The number of the ribs varies greatly; G. B. Sowerisy states 23, Römen $21-23$, and ReEve 24. In my collection there are three specimens from "China" with 25 ribs, but all the specimens from the Gulf of Siam have $21-22$ ribs.

\section{Cardium (Trachycardium) flavum L.}

Cardium favum, I.rnvé, Systema Naturae, ed. X, p. 680, No. 71. - ed. XII, p. 1123, No.87.

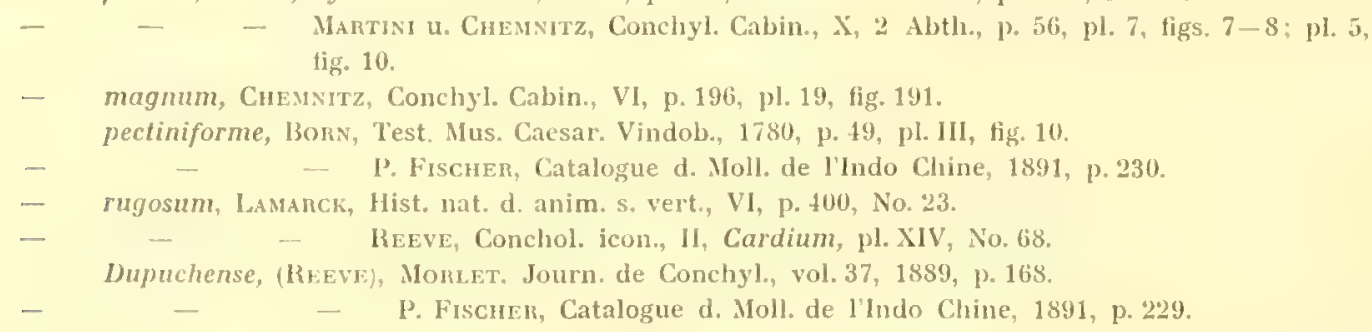

Koh Mak, dead specimens on the coast. Koh Kahdat, 1-5 fathoms, sand, stones (1). North end of Koh Chang, 1-2 fathoms, old coral blocks, several dead specimens, Coast of Koh Kahdat (s/2). 
Long. 8-35 $\mathrm{mm}$.

Pavie in 1884 took it at the islands in the Gulf of Siam (MonLis, Journ. de Conchyl., vol. 37, p. 16\%).

Distribution: - "Bangkok" (Dautzenberg), ${ }^{1}$ Bay of Bengal, Ceylon, Arabian Sea, Persian Gulf, Gulf of Aden, Red Sea, Suez Canal, Madagascar and IRodriguez, Mozambique and Zanzibar, Natal (Sowerby), Malay Archip. (the most commonly occurring species, v. MARTENS), Philippines, north and east coasts of Australia.

Card. Dupuchense, Reeve, is recorded to have been taken at the "Island of Dupuch, Torres Straits (found on the reefs at low water); Dring, H. M. S. Beagle." MELviLI. \& STANDEN ${ }^{2}$ do not record it from Torres Strait, but C. rugosum, Lam. is recorded from "Boydong Cays." ED. Römer" regards, and undoubtedly correctly, C. Dupuchense, Reeve, as a variety of C. flavum.

\section{Cardium (Trachycardium) impolitum, Sow.}

Cardium impolitum, G. B. Sowerry, Proc. Zool. Soc. London, 1840, p. 107.

\begin{tabular}{|c|c|c|c|}
\hline - & - & - & Conchol. Illustr., Sp. 49 , figs. 6 and 66. \\
\hline - & - & - & ReEve, Conchol icon., II, Cardium, Sp. 80. \\
\hline$\ldots$ & - & - & Martini u. Chemnitz, Conchyl. Cabin., X, 2 Abth., p. 62, pl. XI, fig. 12. \\
\hline
\end{tabular}

Koh Chuen, 30 fathoms (1). Between Koh Kut and Koh Kahdat, 10 fathoms, shells ( $1 / 2)$. Between Koh Mesan and Cape Liant, 5-9 fathoms ( $\left.{ }^{1 / 3}\right)$.

Long. $10 \mathrm{~mm}$., alt. $12 \mathrm{~mm}$. (long. $27 \mathrm{~mm}$., alt. $33 \mathrm{~mm}$.).

Distribution: - Karachi (Mervilu a Standen). - China (Sowerby), 'Tahiti (Frauenfeld).

\section{Cardium (Trachycardium) arenicola, Reeve.}

Cardium arenicolum, KLEve, Conchol. icon., II, 1843, Cardium, Sp. 78.

- arenicola, - Lischke, Japanische Meeres Conchyl., II, p. 125.

- maculosum, Solverir, Conchol. lllustr., Sp.48, fig. 63 (non Wool).

Koh Kram 20-30 fathoms $\left(2+{ }^{1 / 2}\right)$. Around Koh Mesan and Koh Chuen, $5-38$ fathoms, stones and shells (8). Koh Kahdat, $1-2$ fathoms $\left({ }^{1} / 2\right)$.

Long. $3 \mathrm{~mm}$., alt. $355 \mathrm{~mm}$. (long. $32 \mathrm{~mm}$., alt. $38 \mathrm{~mm}$.).

Distribution: - Red Sea (Sturany). - Philippines (Cumng), Nagasaki (LISCHKE).

The specimens from the Gulf of Siam have about $52-55$ rils, and as REeve for his species states only 46 ribs, I thought, at first, that the specimens were perhaps Card. transcendens, Melvill \& Standen, ${ }^{*}$ in which species there are 58 ribs. But J. Cosmo Melvill, to whom I sent a few specimens, kindly tells me that they

${ }^{1}$ According to a written communication from PH. DAUtzeniser these specimeus must most properly be referred to C. Dupuchense = pectiniforme, Born. The Iocality "Bangkok" is certainly" due to a mistake.

Journ. Linnean Soc. Zool., vol. XXVII, p. 191.

3 Martini u. Chemnitz, Conchyl. Cabin., Cardiacea, p. 58.

- Journal of the Linnean Soc., Zoology, vol. 27, 1899, p. 199, pl. 11, fig. 21. 
exactly agree with specimens of Card arenicola, Reeve, from Ticao (Philippines) in his collection. LischkE's five specimens from Nagasaki have also only $46-47$ ribs.

\section{Cardium (Papyridea) rugatum, Gron.}

Cardium rugatum, Gronovius, Zoophylacium Gronovianum, 1781, fasc. 11I, p. 266, No. 1125, pl. 18 , fig. 5. Martin u. Chemnitz, Conchyl. Cabin., X Bd., 2 Abth., p. 77, pl. 3, tigs. 1-3.

$-\quad$ ReEve, Conchol. icon., II, Cardium, Sp. 63.
- apertum, Chemsitz, Conchyl. Cabin., 1782, VI. p. 189, pl. 18, figs. $181-83$.

North of Koh Kam, 5 fathoms, gravel (2).

Long. $35-40 \mathrm{~mm}$.

Distribution:- Singapore, Mergui Archip. (v. Martens), Gulf of Manaar (Thunston). - Philippines (Cuming, and others), Hong Kong (Frauenfeld), Gulf of Yedo (Lischke), Java and Flores (Dunker), Amboina (Tapparone Canefri), New Britain (v. MARTENS).

ED. v. MARTENS ${ }^{1}$ thinks that Solen bullatus L. is undoubtedly synonymous with the present species.

\section{Cardium (Papyridea) papyraceum, Chemn.}

Cardium papyracenm, Chemsitz, Conchyl. Cabin., VI, 1782, p. 190, pl. 18, fig. 184.

- $\quad$ - ReEve, Conchol. icon, II, Cardium, Sp.9.

- - _ Martini u. Chemnitz, Conchyl. Cabin., X Bd., 2 Abth., p. 78, pl. 3, fig. 4;

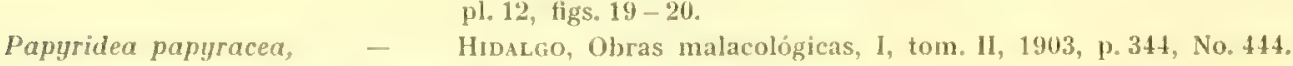

Cardium muticum, ReEve, Conchol. icon., H, Cardium, Sp. 32.

Koh Kahdat, 1 fathom, sand $(1 / 2)$.

Long. $28 \mathrm{~mm}$.

Distribution:- Singapore (Sv. GAD), Ceylon, Gulf of Manaar, Karachi, Mekran Consl, Persian Gulf, Gulf of 'Tadjouralı (Gravier), Suez Canal (Bavay), Mauritius, Nalal. - Ihilippines, Japan (northwards to Hakodate), Blitong (post-tertiary), north and east coasts of Australia.

\section{Cardium (Papyridea) Annae, Pilsbry.}

Cardium anne, Pr.sany, Proc. Acad. Nat. Se. Philadelphia, vol.56, 1904, p. 557, pl. 40, fig. 20.

From Cape Liant to Koh Kut, common, 1-30 fathoms, sand, mud, gravel, and shells.

Long. 3-11 $\mathrm{mm}$.

Distribution: - Japan (PusBry).

Among the individuals from the Gulf of Siam there are several in which the valves are almost quite white excepting the umbones which are purple in colour.

I Rumphius Gedenkboek, 1902. Mollusken, p. 127 (19). 


\section{Cardium (Papyridea) Hungerfordi, Sowb.}

Cardium (Papyridia) hungerfordi, Sowerby, Journal of Malacology, vol. VIII, 1901, p. 103, pl. IX, fig. 5.

- hungerfordi, Sowerby, PilsBry, Proc. Acad. Nat. Sc. Philadelphia, vol, 56, 1904, p. 55j, pl. 41, tig. 17.

Commonly distributed at Koh Chang, Koh Kut, Koh Kahdat and Koh Bidang, 3-30 fathoms, soft clay, sand and mud.

Largest specimen: Long. $9.5 \mathrm{~mm}$.

Distribution:- Japan (Sowerby, PILsbry).

This species may easily be confounded with the young of Card. coronatum, Spgl., from which it is, however, distinguished by a stronger gloss, the absence of ribs at the middle, and by its often being ornamented with two reddish-brown tints at the middle on each side of the umbones (young specimens of C. coronatum have often reddish-brown wavy lines transversely across the valves), the valves are more tumid, and the posterior side somewhat prolonged in a rostrum-like manner. Prusbry, however (loc. cit. p. 556), describes two varieties of C. Hungerfordi, to which some of these characters cannot be applied.

Cardium (Laevicardium) Australe, Sow.

Cardium Australe, Sowerby, Proc. Zool. Soc. London, VIII, 1840, p. 105. - Conchol. Illustr., part 48 , Cardium, figs. $12-12^{*}(1834)$.

- australe, - Martini u. Chemnitz, Conchyl. Cabin., X, 2 Abth., p. 70, pl. 12, figs. 8-9.

- - - Reeve, Conchol. icon., II, Cardium, Sp. 97.

- (Bucardium) australe, Sowerby, EDg. Smiti, liep. on the Lamellibranchiata of the Challenger. Exped., p. 160.

(Laevicardium) - _ - EDG. SMитн, Moll. of the Maldive and Laccadive Archipelagoes, 1903, II, pl. II. p. 625 , No. 343 .

- pulchrum, ReEve, Conchol. icon., II, 1845, Cardium, Sp.98.

- (Papyridea) pulchrum, Reeve, ED.v. Martens, Mollusken d. Maskarenen u. Seychellen, 1880, p. 148.

- - - - EDG. SMitr, Rep. Zool. Collect. Voyage "Alert," 1884, p. 507, No. 11.

West of Koh Chang, 20 fathoms, mud (2).

Long. 11-12 $\mathrm{mm}$.

Distribution:- Salang, Mergui Isls., Andamans, Ceylon, Gulf of Manaar, Maldive Archip., Gulf of Oman, Aden, Red Sea, Seychelles, Amirantes, Mascarenes, Zanzibar, Cape of Good Hope $\left(\mathrm{J}_{\mathrm{AY}}\right)$. - Poulo Condor, Philippines, China Sea, "Coasts of Australia," Lifu, Viti Isls., Samoa Isls.

As neither Sowerby nor Edg. Suitu mention Card. Australe, Sow., in their lists of the Mollusca of South Africa I think that JAY's record of the occurrence of the species at the "Cape of Good Hope" should be regarded as open to doubt. It is a mistake when EDG. Surth in his report on the Lamellibranchiata of the Challenger Expedition writes regarding this species that "it is not apparently adorned with an epidermis, judging from the series of specimens which I have examined," because already in 1878, in the "Proc. Zool. Soc. London," p. 819, he had written concerning this same species "The Andaman examples are rather young and bear the remains 
of their epidermis, which takes the form of very thin, short, irregular yellowish lamella arising from the radiating stria." In the specimens from the Gulf of Siam this epidermis is found especially upon the front and hinder sides of the valves; in addition, there is present especially upon the posterior end, slight remnants of epidermis between the radiating ribs. MeLvill and STANDEN ${ }^{1}$ consider C. tenuicostatum, Lam. to be a variety of C. Australe, Sow.

\section{Cardium (Laevicardium) lobulatum, Desh.}

(Pl. V, Figs. 16-19).

Cardium lobulatum, Deshayes, Proc. Zool. Soc. London, XXII, 1854, p. 332, No. 68.

At Koh Kalıdat, 1 - 10 fathoms, sand and mud (14). South of Koh Mak, 5-6 fathoms (2).

Long. $23 \mathrm{~mm}$., alt. $26 \mathrm{~mm}$.

Distribution:- Maldive Archip. - Philippines.

I owe thanks to Mr. EDG. SMrti for the determination of the present species.

Hemicardium (Lunulicardia) retusum L.

Cirdium retusum, LINNÉ, Systema Naturae, ed. XII, 1767, p. 1121, No. 75.

- - Martini u. Chemnitz, Conchyl. Cabin., X, 2 Abth., p. 118, pl. VI, figs, 1-4.

- Linné, ReEve, Conchol. icon., II, Cardium, Sp. 103.

- subretusum, Sowerby, Reve, Conchol, icon., II, Cardium, Sp. 100.

Several (23) specimens taken between Cape Liant and Koh Kut, 1-15 fathoms, sand, gravel and mud.

The specimens are all small, the largest specimen is $23 \mathrm{~mm}$. broad.

Distribution:- Bay of Bengal, India (Madras), Ceylon, Gulf of Manaar, Red Sea, Suez Canal ("rare" M'Andrew, Cooke), Seychelles, Réunion, Zanzibar. Philippines, Torres Strait.

The records of the different authors concerning the distribution of this species lo China (v. Martens, ReEve, and others) and Japan (Dunker, and on his authority PrisBry) areopen to doubt, neither Laschke (dapan. Meeres Conchylien) nor P'. Fischen (Catalogue d. Moll. de l'Indo Chine) mention this species from these regions.

\section{Hemicardium (Fragum) unedo L.}

Cardium unedo, LINNÉ, Syst. Nat, ed. X, 1758, p. 680 , No. 68.

- $\quad$ - Mus. Ludovica Ulrica reg., 1764, p. 488, No. 40.

Rekvi, Conchol. icon., II, Cardium, Sp. 13.

Martini u. Chimnitz, Conchyl. Cabin., $\mathbf{x}, 2$ Ablh., p. 101, pl. 4, ligs. $11-12$.

Ilemicardia unedo, Linvé, I. Montet, Journ. de Conchyl., vol. 37, 1889, p. 168, No. 58.

At Koh Kahdat, 1-5 fathoms, sand (14).

Islands in the Gulf of Siam (MORLET).

Long. $6-8 \mathrm{~mm}$.

1 Proc. Zool. Soc. London, 1906, p. 837 . 
D istri bution:- Singapore, Mergui Archip., Nicobars, Madras, Ceylon, Mauritius. - Poulo Condor, Cochin China, Philippines, Moluccas, Java, Malay Archip., New Guinea, 'Torres Str., Port Molle (Queensland), West Australia, Lifu Isl., Salomon Isls., Viti Isls.

The Danish Expedition obtained only quite small specimens of this species from the Gulf of Siam. Mr. Pн. DAutzenberg writes to me that his Hemicard.tegulatum ${ }^{1}$ must be regarded as a variety of Hemicard. unedo $\mathrm{L}$.

\section{Hemicardium (Fragum) fragum L.}

Pl. V, Fig. 20)

Cardium fragum, LiNeE, Syst. Nat, ed. X, 1758, p. 679, No. 67. - ed. XII, p. 1123, No. 83.

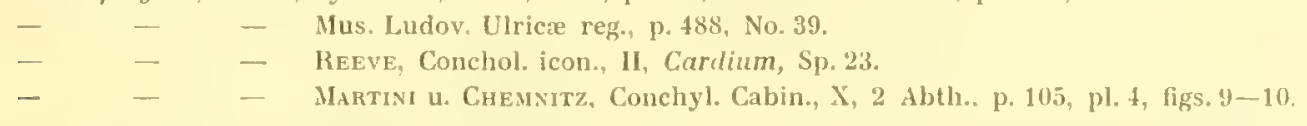

Between Koh Kahdat and Koh Kut, 6 fathoms, clay mixed with sand (1/2). Koh Kahdat at the strand, numerous specimens. Koh Mak, sandy coast ( $/ 2)$.

Long. 4-10 $\mathrm{mm}$.

Distribution:- Andamans, Nicobars, Gulf of Tadjourah, Maritius, east coast of Africa, Querimba Isls. - China Sea, Philippines, Amboina, Java, Borneo, Sulu Isls., Liukiu Isls., Torres Strait, Port Curtis and Mast Head Reef (Queensland), New Zealand, New Caledonia, Gilbert Isls., Funafuti (Ellice Isls.), Paumolu Isls.

The specimens which have been obtained are all very small. According to O. Finsch this species is used as food in the Gilbert Islands. Several specimens of a peculiar variety (var. carinata m.), with a decidedly prominent keel extending from the umbo down towards the hinder angle of the ventral side, produced by the strong development of the two ribs at that place, have been taken on the strand of Koh Kahdat and at Koh Chang; this variety is figured on Pl. V, Fis. 20.

Hemicardium (Fragum) carditaeforme, Reeve.

$$
\text { (PI. V. Figs. 21-22). }
$$

Cardium Carditeforme, REEvE, Conchol. icon., II, Cardium, Sp. 127.

Between Kol Mesan and Koh Chuen, 15-38 fathoms, stones with shells (7). Koh Chuen, 10-15 fathoms (1). Between Koh Mesan and Cape Liant, 5-9 fathoms, sand $(1 / 2)$. Strand of Kolı Kahdat $(1 / 2)$. West of Koh Kong, 10-15 fathoms (1).

Long. $4-9 \mathrm{~mm}$.

Distribution:- Andamans, Gulf of Suez ("rare" M'Anorew, Cooke).

As the figure by REEve is not good, I give a new figure of the species.

Hemicardium (Ctenocardium) fornicatum, Sow.

Cardium fornicatum, Sowerer, Jroc. Zool. Soc. London, 1840, p. 110.

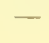

Conchol. Illustr., Sp. 84, fig. 50.

ReEve, Conchol. icon., II, Cardium, Sp. 110.

'Journal de Conchyliologie, vol. 48, 1900, p. 5. 
Hemicardium (Ctenocardium) fornicatum, Sowerby, Metvit, \& Standen, Proc. Zool. Soc. London, 1906, p. 840 .

Cardium Adamsii, ReEve, Voyage of "Samarang," p. 77, pl. 22, fig. 2.

- virgo, ReEve, Conchol. icon., 1845, II, Cardium, Sp. 120.

Commonly distributed from the Gulf of Rayong and Cape Liant to Koh Kut, 1-15 fathoms, sand, mud, and gravel (26).

Long. 6-26 $\mathrm{mm}$.

Distribution:- Andamans (EDg. Smitu), S. Nilandu and N. Male Atoll (EDG. Smith), Persian Gulf (Melvill \& Standen), Red Sea (Stunany), Providence Isl., Mascarenes ("Alert"). - Borneo ("Samarang"), Tizard Bank, southern China Sea (EDG. Suitu), Tonga Isls. ("Challenger").

The present species is often difficult to distinguish from Hemicardium imbricatum, Sow. The number of the ribs is variable; the intercostal sculpture (at any rate in the material before $m$ ) is the same in both the species. SowErBY says regarding fornicalum that the ribs are set with "vaulted imbrications," while " Eng. SMITH' states regarding the same species that they are ornamented with "short hollow spines." In younger and well-preserved specimens these "spines" may be as well-developed as in imbricatum. The specinens from the Gulf of Siam are quite white on the outer side of the valves and precisely resemble Card. virgo, Reeve, which is synonymous with C. fornicatum, Sow.

Hemicardium (Ctenocardium) imbricatum, Sow.

Cardium imbricatum, SowenBY, Proc. Zool. Soc. London, 1840, p. 110.

- - C Conchol. Illustr., Sp. 85, fig. 48.

- - - Reve, Conchol. icon., II, Cardium, Sp. 28,

Several (22) specimens taken at Koh Chang, Koh Mak, Koh Kahdat, Koh Kut, Koh Samit and several places in 5-30 fathoms, mud, gravel, and clay mixed with sand.

Long. 6-27 $\mathrm{mm}$.

Distribution:- Torres Strait (Murray Isl.), ofl Cape York (North Australia), West Australia (Swan River).

Card. hystrix, Reeve, from the Philippines and the Andamans, with strongly developed spines, approaches somewhat Card. imbricatum, Sow.

\section{Fam. Tridacnidae.}

\section{Tridacna squamosa, Lam.}

Tridacna squanosa, Imasuck. Hist. nat. d. anim. s. vert., VI, 1 p. 1819 , p. 106. - éd. 2, VII, 1836, p. 10. (Ooy et Gajmand, Voyage de l'Astrolabe, II, 1833, p.487, p1. 79, fig. 1.

Martinı u. Cuemnitz, Conchyl, Cabin., VIII, 4 Abth., p. 5, pl. 1, figs. $1-3$; pl. 2, tigs. $1-2$.

Report on the Lamellibranchiata of the Challenger Expedition, p. 164. 
Tridacna squamosa, Lamarck, ReEve, Conchol. icon., XIV, Tridacna, Sp. 3.

\begin{tabular}{|c|c|c|c|}
\hline- & - & - & Soweriy, Thesaurus Conchyl., V, 1887, p. 180, pl. $485-489^{\circ}$, figs. $2,7,15,17$. \\
\hline - & - & - & L. Morlet, Journ. de Conchyl., vol. 37,1889, p. 168. \\
\hline - & - & - & P. Fischer, Catal. de Moll. de l'Indo Chine, p. 228 . \\
\hline- & - & - & Hidalgo, Obras malacológicas, I, tom. II, 1903, p. 386, No. 489. \\
\hline
\end{tabular}

Koh Kahdat, 1-2 fathoms, coral (1).

Islands in the Gulf of Siam (MORLET).

Long. $245 \mathrm{~mm}$.

Distribution:- Singapore, Mergui Isls, Nicobars, Ceylon, Seychelles. Poulo Condor, Annam, Philippines, Loo Choo Isls, Japan, Moluccas, Sulu Isls., Java, Timor, New Guinea, Torres Strait, North and East Australia, New Caledonia, South Sea Islands "What information we have, suggests that the range of this species is almost co-extensive with that of the reef-building corals." CH. HEDLEy loc. cit.).

EDg. SMrti says" "I should not be surprised if Tridacna squamosa or Tridacna rudis should prove to be the early stages of this colossal form (Tridacna gigas)." A. H. CoOKE 2 and CH. HEDLEY ${ }^{3}$ have arrived at a similar conclusion; HedLEY thinks that "No characters of permanent value separate T. squamosa from T. gigas."

\section{Tridacna crocea, Lam.}

Tridacna crocea, LAMARck, Hist. nat. d. anim. s. vert., VI, 1 p. 1819, p. 106 . - éd. 2, VII, 1836, p. 10.

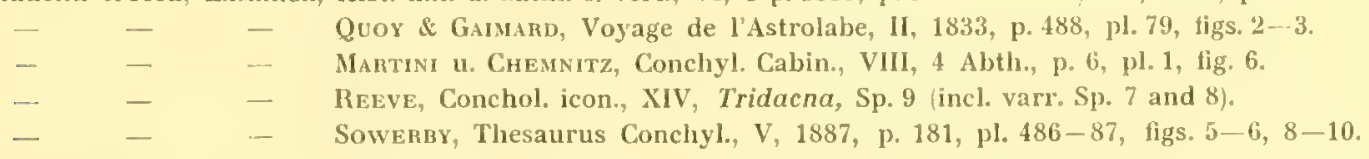

North end of Koh Chang, 1 fathom, boring in old coral blocks (2). Koh Kahdat, in coral blocks (1).

Long. $115 \mathrm{~mm}$, alt. $84 \mathrm{~mm}$.

Distribution:- Singapore, Mergui Isls., Andamans, Nicobars, Persian Gulf, Aden, Madagascar. - Philippines, Loo Choo Isls., Moluccas, Cape York (N. Australia), Lifu, New Ireland, Rarotonga.

\section{Fam. Chamidae.}

\section{Chama multisquamosa, Reeve.}

Chama multisquamosa, ReEve, Conchol. icon., IV, 1846, Chama, Sp. 12.

Many specimens taken in 23 different localities between Koh Rin and Koh Kut, 1-30 fathoms, sand, shells, clay and mud.

1 Lamellibranchiata of the Challenger Expedition, p. 171.

"Annals \& Magaz. Nat. Hist., Ser. 5, vol. 18, p. 97.

3 Australian Museum, Sydney, Memoir III, 1896-1900, pp. 504-5. 
Largest specimen: Long. $31 \mathrm{~mm}$., alt. $26 \mathrm{~mm}$.

Distribution:- Singapore (Iow water, Sv. Gad), Ponlo Condor, Philippines. It is very disheartening to look through the literature of the species of the genus Chama, and of their distribution, because of the uncertainty and casuality which prevail in it; this is of course for the greater part due to the bad diagnoses and figures in which the characteristic marks of distinction, e. g. in the sculpture, are disregarded, and instead are given long descriptions of insignificant and usually individual details pertaining to colour and outline; but certainly authors are often too careless in determining solitary specimens without having a large quantity of material at their disposal for comparison - better no determination than an erroneous one. It is very characteristic when ED, v. ManTENs" says "Die Arten dieser Galtung sind sehr schwer gegeneinander abzugrenzen, daher ihre Bestimmung und Benennung oft etwas willkürlich," and A. H. Cooke:" "It would be impossible here to enter into a discussion of the facts in the case of a genus notoriously so variable as Chama, when REEve has made fifty-five species out of material probably better represented by ten."

Chama fragum, Reeve.

Chama fragum, ReEve, Conchol. icon., IV, 1847, Chama, Sp. 48.

Martini u. Chemeitz, Conchyl. Cabin., VIII, 4 Abth., p. 22, pl. 10, figs. $2-3$.

Crosse \& Fischer, Journ. de Conchyl., vol. X̌L, 1892, p. 76 .

Koh Kram, 30 fathoms (2/2). S. of Koh Chuen, 30 fathoms, shells (2). Koh Chang, at low tide (1). North end of Koh Chang, 1 fathom, old coral blocks (2). The sound between the stations, 3-5 fathoms, soft clay (1). Coast of Lem Ngob (1/2).

West coast of Cambodge in the Gulf of Siam (PAviE).

Long. $27 \mathrm{~mm}$., alt. $31 \mathrm{~mm}$.

Distribution:- Persian Gulf (Melvili \& Standen), Aden (Shopland), Red Sea (Stukany). - Philippines, Hong Kong, Spencer's Gulf, South Australia"? (Angas), Samoa and Cook's Isls.? (Mus. Godeffroy).

Chama granulata, Clessin, 3 is probably nothing else but the present species.

Chama cristella, Lam.

Chama cristella, Laßanck, Hist. nat. d. anim. s. vert., VI, 1819, p. 96. - éd. 2, 1835, VI, p. 585. ReEve, Conchol. icon, IV, 1847, Chama, Sp. 42.

Reeveana, Clissin, Mantini u. Chemattz, Conchyl. Cabin., Vili, 4 Abth., p. 38, pl. 16, figs. 3-4.

Between Koh Mesan and Koh Chuen, 15 fathoms, stones (2). S. of Koh Chuen, 30 fathoms, shells (1).

Long. $21 \mathrm{~mm}$., alt. $28 \mathrm{~mm}$.

Distribution:- Mergui Archip., Moluccas (Cuessiv). - Java, Celebes, Spencer's Gulf? (South Australia, Angas).

I Die Mollusken d. Maskarenen u. Seychellen, 1880, p. 147.

2 Annals and Magaz. of Nat. Hist., Ser. 5, vol. 18, p. 96.

- Martini u. Chemsitz, Conchyl. Cabin., loc. cit., p. 40 , pl. 17, fig. 4. 
Clessin, in his deficient Monograph of the genus Chama (in Mantini u. ChemNitz's Conchyl. Cabin.), states that the species, described by REEve under the name of Ch. cristella, differs from Lamarch's species, as LAMARCK's diagnosis does not at all agree with REEvE's form; therefore CLESSiN gives REEvE's species a new name (Reeveana, Clessin) and applies LAMARCK's name to a West Indian species which does not at all agree with LAMARCK's diagnosis. The whole of this change is un. necessary and incorrect; REEVE's and LAMARCK's forms are undoubtedly identical; besides REEVE expressly says: "the example here figured has been satisfactorily identified with LAMARCK's original specimen in the collection of M. DeLESSERT."

Chama pulchella, Reeve.

Chama pulchella, ReEve, Conchol. icon., IV, 1846, Chama, Sp. 10.

- - _ Meport Zoolog. Collect. Voyage "Alert," 1884, p. 102, No. 35.

Koh Mak, sandy coast $(1 / 2)$.

Long. $35 \mathrm{~mm}$., alt. $30 \mathrm{~mm}$.

Distribution:- Torres Strait (Melvill \& Standen), Port Molle, Queensland (Coppinger), Cape Upstart, New Holland (Jukes).

The exterior of the somewhat worn shell collected at Koh Mak is of a pretty pink colour.

Note. A small, solitary valve, which somewhat recalls Chama cornula, Chemnitz, has been taken at Koh 'rulu.

Chama cornuta, Chemvitz (var.), Conchyl. Cabin., VII, 1781, pp. 150 and 154, pl.52, fig. 518.

Der Naturforscher, XX, 1784, p. 13, pl. 1, fig. 3.

LAMARCK ${ }^{-1}$ was correct in doubting whether Cnemnitz's Ch. cormuta was identical with his Ch. florida from St. Domingo (therefore in the list of synonyms belonging to that species he has queried the cilation). Cuessin, ${ }^{2}$ however, in his Monograph of Chama has, as a matter of course, put Chemnitz's species as a synonym of C. florida, Lam., which is entirely wrong. Chemnitz's original specimen, which has been at my disposal, is from the Nicobars, and is a young individual which, because it has not been attached to any other object, has developed its umbones into a pair of twisted horns; as it is somewhat worn, it is not easy to form any definite opinion regarding this species.

\section{Fam. Myidae.}

\section{Corbula (Aloidis) crassa, Hinds.}

Corbula crassa, Hinos, Proc. Zool. Soc. London, XI, 1813, p. 55.

- - - Zoology of the voyage of H. M. S. "Sulphur." Mollusca, p. 67, p1. 20, figs. 1-3.

- - - Reeve, Conchol. icon., II, Corbula, Sp. 8.

- - - Hanlex, Catal of recent biv, shells, p. 344, pl.12, fig. 29.

- - _ var, Edg. Sirti, Lamellibranchiata of the Challenger Exped., p. 30.

1 Hist. nat. d. anim. s. vert., 2 éd., VI, p. 583.

2 Martini u. Chemitit, Conchyl. Cabin., VIII, 5 Abth., p. 12.

D K. D. Vidensk. Selsk. Skir., 7. Rarklie, uaturvidensk, og mathem, Afu. V. 3. 
E. of Cape Liant, 9 fathoms, shells (5). Gulf of Rayong, 7-10 fathoms, sand and mud (2). S. of Koh Samit, 14-20 fathoms, mud (6). S. of Koh Tulu, 10 fathoms, mud (2). W. of Kolı Chang, 20 fathoms, mud (1/2). N. of Koh Kahdat, 4-5 fathoms, coarse sand (1). Koh Kahdat, 1-5 fathoms, sand (1). Between Koh Kahdat and Koh Kut, 6-10 fathoms, mud mixed with sand (5/2). Koh Mak, sandy coast ( $\left.{ }^{2} / 2\right)$. S. of Koh Mak, $5-6$ fathoms (2). W. of Koh Kong, 10-15 fathoms (1).

Long. 8-24 mm.

Distribution:- Singapore, Strait of Malacca, Mergui Archip., Andamans, off Port Blair, Andaman Isls, 100 fathoms (Edg. Smitu), Gulf of Manaar. - Poulo Condor, Philippines, Formosa, Strait of Macassar, New Guinea, Torres Str., Mast Head Reef () neensland), Porl Lisinglon, Dampier's Land (NW. Australia), NE. Australia.

The specimens, for the most part, are thick-valved and vary greatly in form, but quite thin-valved specimens also occur: thus, for example (from Singapore) a left valve of the following dimensions:- long. $19 \mathrm{~mm}$, alt. $7 \mathrm{~mm}$, crass. $4 \mathrm{~mm}$; it is very thin-valved, and without a trace of the denticulation upon the dorsal and ventral margins characteristic of the species; it greatly resembles EdG. SmTH's species C.Macgilliorayi, and like the latter it has a shallow depression down the middle (which C. crassa also very frequently has); the hinge characters are also less pronounced than in the thick-valved specimens of $C$. crassa of the same size, from which it appears to differ greatly, but it is, in reality, only an unthickened individual.

Corbula (Aloidis) tunicata, Hinds.

Corbula tunicata, Hixus, Proc. Zool. Soc. London, 1843, p. 55.

$$
\begin{aligned}
& \text { - - - ReEve, Conchol. icon., II, Corbula, Sp.5. } \\
& \text { - _ Zoology of the voyage of "Sulphur," Mollusea, p. 68, No. 281, pl. 20, figs. 4-5. } \\
& \text { - _- _ _ Evg. Smitr, Lamellibranchiata of the Challenger Exped., 1. } 29 . \\
& \text { - Pritcialio and GathifF, P'roc. Roy. Soc. Victoria, vol. 16, 1903, p. } 101 . \\
& \begin{array}{l}
\text { - scaphoides, - Proc. Zool. Soc. London, 1843, p.56. } \\
\text { - } \quad \text { ReEve, Conchol. icon., II, Corbula, Sp. 24. }
\end{array} \\
& \text { EDG. Smтr, Lamellibranchiata of the Challenger Exped., p. 32, pl. 7, fig. } 3 . \\
& \text { Pritciand and Gathife, Proc. lioy. Soc. Victoria, vol. 16, 1903, p. } 101 .
\end{aligned}
$$

NW. of Koh si Chang, 10 fathoms, mud (1). Gulf of Rayong, 7-10 fathoms, mud $(1 / 2)$. Sound of Koh Chang, 5 fathoms, soft clay $\left({ }^{1} / 2\right)$. West coast of Koh Chang, 10 fithoms, mud $\left({ }^{2} / 2\right)$. S. of Koh Bidang, 9 fathoms, mud (1). S. of Koh Mak, 5-6 fathoms (4). Between Koh Kahdat and Koh Kut, 6-10 fathoms, mud mixed with sand ("I/2). N. of Koh Kul, 10 fathoms, mud ("2/2). W. of Koh kut, 15 fathoms, mud (3).

Long. 7 - $25 \mathrm{~mm}$. (long. $25 \mathrm{~mm}$., alt. $17 \mathrm{~mm}$., crass. $14 \mathrm{~mm}$.).

D istribution: - $\left(t\right.$. = tunicuta, Hinds; $s_{0}=$ scaphoides, Hinds $)$. Singapore $\left(s_{\text {. }}\right)$, Mergui Archip. (t.), Ceylon (s.), Cape of Good Hope (t.). - Philippines (t. $\left.s_{0}\right)$, China Sea $\left(t_{*}\right)$, Hong Kong Harbour (s.), Amboina ( $\left.t_{*}\right)$, Strait of Macassar ( $t_{*}$ ), Arafura Sea (t.), Torres Strait (t.s.), Cape York (s.), Port Jackson, Sydney (t.s.), Mast Head Reel, Queensland (s.), Port Molle, Queensland (t.s.), Victoria (t.s.), Port Darwin, NW. Australia (l.), 'T'asmania (s.). 
I cannot find sufficient reason for separating the two forms tunicata and scaphoides as distinct species, the differences are entirely individual. Among the rather large quantity of material which I lave at my disposal, are several transitional forms. The vivid coloration which Hinds has given in his figure of lunicata in the report of the "Sulphur" Mollusea, was not found by me in any of the individuals I have had for examination.

Corbula (Aloidis) erythrodon, Lam.

Corbula erythrodon, LAsarck, Hist. nat. d. anin. s. vert., V, 1818, p.496. No.3. - éd. 2, VI, p. 138, No. 3. $\begin{array}{lll}- & - & \text { Reve, Conchol. icon., II, Corbula, Sp. } 4 . \\ - & - & \text { Lischke, Japan. Meeres-Conchyl., I, p. } 136\end{array}$

E. of Cape Liant, 9 fathoms, shells $(1 / 2)$. N. of Koh Kam, 5 fathoms, gravel (2). Between Koh Riot and Koh Mesan, 3-5 fathoms, sand (1). Between Koh Mesan and Cape Liant, 9 fathoms (1). Koh Kahdat, 1-5 fathoms, sind $\left(2+{ }^{+/ 2}\right)$. Between Koh Kut and Koh Kahdat, 10 fathoms, shells (1/2).

Long. $7-20 \mathrm{~mm}$.

Distribution: - Poulo Condor, China, Japan, New Zealand.

Corbula pallida, Hinds (recorded from Singapore and the Nicobars), is certainly synonymous with the present species.

\section{Corbula lineata n. sp.}

(Pl. V, Figs. 23-24).

This species is oblong-triangular in form, somewhat inequivalve (the right valve being somewhat larger than the left), moderately convex, the valves lhick and solid, and whitish in colour with slight indication of pale red. The umbo is situated at about the middle, often nearer to the front end. The apices of the umbones are placed close together and they curve over towards the front. From the umbo a sharp keel extends over each valve down towards the posterior extremity, which is prolonged in a rostrum-like manner. The dorsal margin slopes gradually down towards the front end, from whence it is continued in a curve down to the straight ventral margin. Towards the pointed posterior end the dorsal margin slopes in a straight line. In both valves, when the animal has reached a certain size, the ventral margins turn back and grow inwards towards each other. The portion of the posterior end which is bounded by the two keels forms an oval; towards the central line (the opening between the valves) of this oval there occurs on each side a smailer keel, by which another oblong oval is formed. The surface of the valves is covered with close-set, concentric, raised thread-like lines, the interstices between which are finely striped transversely with close-set radiating lines. The interior of the valves is white, the muscle impressions and the pallial line are yellow; a narrow depression extends from the umbonal region down towards the ventral margin. The solitary cardinal tooth in the right valve is large, strong and curved upwards; it fits into a corresponding pit in the left valve, behind which there is a large denticle supporting the ligament. 
Long. $8.5 \mathrm{~mm}$, alt. $5 \mathrm{~mm}$, crass. $4.5 \mathrm{~mm}$.

Between Koh Mesan and Cape Liant, 9 fathoms (3).

'The present species, which somewhat resembles the West Indian species Corb. Kjaeriana, C. B. Amams, ${ }^{1}$ is very characteristic and can easily be distinguished by its form and beautiful sculpture.

\section{Corbula subquadrata, Melvill.}

Corbula subquadrata, Melvil., Proc. Zool. Soc. London, 1906, p. 843, pl. 56, fig. 7.

Koh Chuen, 30 fathoms (1). Coast of Lem Ngob), low tide, stones (9). Koh Chang, low tide (1/2). North of Koh Kut, 10 fathoms, mud (i/2).

Long. 25-6 mm. (long. $5 \mathrm{~mm}$., alt. $35 \mathrm{~mm}$, crass. $25 \mathrm{~mm}$.).

D istribution:- Bombay, Persian Gulf, Gulf of Oman.

This species varies greatly both in regard to outline and convexity; several of the specimens from the Gulf of Siam agree exactly with Melvill's figure, while others differ in outline and are oblong (long. $6 \mathrm{~mm}$, alt. $4 \mathrm{~mm}$, crass. $3.5 \mathrm{~mm}$.) ; but the peculiar hanging rostrum and the strong sculpture are found in all the individuals. Mervict, in his diagnosis, does not mention that the concentric folds upon the whole surface and also the interstices between them, seen under magnificalion, are transversely closely striped; this ornamentation is very characteristic, and occurs in all my specimens. In full-grown specimens there are usually more than "about 12 concentric ribs" (as stated by Melvill), and although in the umborial region their prominence is extremely slight, yet often at least fourteen fully developed folds may be counted.

Corbula arcaeformis n. sp.

(Pl. V, Figs. 25-26).

The shell is oblong, very convex, clear-white, thin and dully pellucid; it is twice as long as it is high, rounded at the anterior end and drawn out into a point at the posterior end. From the beak a keel extends to the point of the posterior end; the space thereby formed between the dorsal side and the keel, is divided into two halves by a groove which originates at the beak. The middle portion of the shell, especially towards the ventral side, is depressed, and this makes the ventral margin concave. The surface is covered with fine, irregular lines of growth, which towards the ventral side are coarser; these are most pronounced upon the space mentioned above limited by the keel. Under magnification may be seen in the shell-substance a great many fine, white lines, which radiate from the umbones down towards the ventral margin; in quite young individuals and in the umbonal region of well-preserved, older specimens, these lines may be seen as small, fine, irregular, slightly raised stripes. The beaks are situated in the front third of the

1 Dall, Report on the Mollusca coll. by the Steamer "Blake," I, 1886, p. 316, pl. I, fig. 6. The American conchologists erroncously name this species C. Kjoeriana. 
shell and curve over towards the front. In the right valve there is one cardinal tooth, which fits into a corresponding pit in the left valve, behind which is a stout process or denticle supporting the ligament. The interior of the valves, like the exterior, is clear-white in colour.

Long. $9.5 \mathrm{~mm}$., alt. $5 \mathrm{~mm}$., crass. $5.5 \mathrm{~mm}$.

Between Koh Kut and Koh Kahdat, 10 fathoms, shells $(2 / 3)$. Koh Kahdat $(1 / 2)$. South of Koh Kahdat, 8-10 fathoms, mud ( $4 / 2)$.

This small characteristic species, which in form recalls an Arca (Barbatia), stands nearest Corbula tenuis, Sow., from which it differs, however, in many points. The specimens which I have before me are not well-preserved, no trace of epidermis is seen upon any of them; also, I cannot, unfortunately, state anything about the reciprocal size of the two valves. But in all probability, the difference in size is not very great, as both right and left valves are at hand, but of different individuals.

Corbula rugifera, A. Ad. (Smith).

Corbula rugifera, A. AdAss, MS. in Coll. Cuming. Brit. Mus.

Edv. Smith, Proc. Malacolog. Soc. London, V, 1903, p. 399, No. 373, pl. 15, figs. $9-10$.

H. Adams, Melvill and Standen, Proc. Zool. Soc. London, 1906, p. 843.

Koh Kram, 20 fathoms $(2 / 2)$.

Long. 3.5-8 $\mathrm{mm}$.

Distribution:- Singapore (Sv. Gad, Zoolog. Mus. Copenhagen). Karachi (Hindustan, Melvill). Umkomaas (South Africa, Burnup).

After EDG. SMITH in 1903 had published the description of the present characteristic species from South Africa, Melvilu, in 1906, recorded that it had been taken at Karachi. Its occurrence at Singapore and in the Gulf of Siam, renders it probable that later on it may also be found in the interjacent waters.

\section{Corbula Taheitensis, Lam.}

Corbula taïtensis, LaMARCK, Hist. nat. d. anim. s. vert., V, 1818, p. 496 , No. 5.

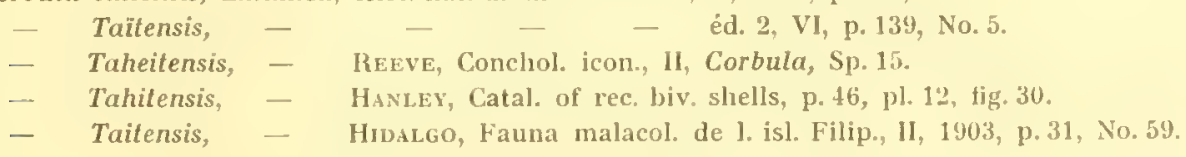

Koh Chuen, 30 fathoms (1/2). Between Koh Mesan and Koh Chuen, 25-38 fathoms, stones and shells $(1+3 / 2)$. North end of Koh Chang, 12 fathoms, old coral blocks $(1 / 2)$.

Long. $6-8 \mathrm{~mm}$.

Distribution - Aden. - Philippines, New Guinea, Torres Str., Tahiti, Funafuti Atoll (HedLey). 
Corbula sulcata, Lam.

Corbula sulcata, Lamarck, Systême d. anim. s. vert., 1801, p. 137. - Hist. nat. d. anim. s. vert., V, 1818 , p. 495, No.2. - éd. 2, VI, p. 138, No. 2.

Encyclop. méthod. Hist. nat. d. vers, 11, 2, 1830, p. 8, No. 1. - Tableau encycl. et méth. Moll. test., pl. 230, 1ig. 1.

- $\quad$ - Hanlex, Catal. of rec. bivalve shells, p. 45, pl.13, tig. 48.

- - $\quad$ - ReEve, Conchol. icon., II, Corbula, sp.2.

NW. of Koh si Chang, 10 fathoms, mud (1). North of Koh Kut, 10 fathoms, mud $(18 / 2)$. W. of Koh Kut, 10-15 fathoms, mud $\left(1+{ }^{22} / 2\right)$. Between Koh Kut and Koh Kahdat, 10 fathoms, shells (12/2). Koh Kahdat ( $7 / 2)$.

Long. 5-14 mm. (alt. $12.5 \mathrm{~mm}$, long. $14 \mathrm{~mm}$.).

Distribution:- LAmarck records: l'Océan indien? Hanley and Reeve: Senegal. Rochebrune: Porto-Praya (Rang).

Corbula fortisulcata, Smith, is very closely allied to the present species. In the British Museum there is a specimen labelled "Corbula fortisulcata, Smith var." from "Jack's Island, South Sea," which agrees completely with some of the specimens from the Gulf of Siam, and these cannot possibly be separated from C. sulcata, as there are evenly transitional forms between them and the typical C. sulcata, Lam.

\section{Corbula monilis, Hinds.}

(P1. V, Figs. 37-30).

Corbula monilis, Hinds, Proc. Zool. Soc. London, XI, 1843, p. 58.

- - - Reve, Conchol. icon., II, Corbula, Sp. 35.

- - - Evg. Sмтн, Lamellibranchiata of the Challenger Expedit., p. 34.

- - _ Hidalgo, Fauma malacol. de l. isl. Filipinas, II, p. 33, No.64.

Many specimens taken in 19 different localities between Koh Kram and Koh Kul, 1-30 falhoms, sand, mud and shells.

Long. $1.5-3 \mathrm{~mm}$.

Distribution: - Singapore (2-3 fathoms, coral reel, Sv. GAD). - Philippines, Torres Strait, Mast Head Reef (Queensland),

Corbula solidula, Hinds.

(P). V, Figs. $31-34$ and $42-44$ ).

Corbula solidula, Hisis, Proc. Zool. Soc. London, XI, 1843, p. 58.

ReEvi, Conchol. icon., II, Corbula, Sp. 41.

- - - Mollusca of the voyage of H. M.S. "Sulphur," 1845, p. 69, No. 288.

- eburnea, - Proc. Zool. Soc. London, XI. 1843, p. 58.

ReEve, Conchol icon., II, Corbula, Sp. 42.

Mollusca of the voyage of H. M. S. "Sulphur," 1845, p. 69, No. 290, pl. 20, tig. 14.

- - Hidalgo, Fauna malacol. de J. isl. Filipinas, 11, 1903, p. 34, No.67.

Many specimens laken in 26 different localities between Koh si Chang and Koh Kut, 1-30 fathoms, mud, sand, shells and clay.

Long. 2-4.5 $\mathrm{mm}$. 
Distribution:- Philippines, Strait of Macassar, New Guinea.

Hinds says regarding eburnea "This shell closely approaches C. solidula, but is distinguished by its somewhat more triangular shape, polished, ivory-like, flattened valves, and the slightly sulcate sculpture." All these characters are however not constant; among the large quantity of material at my disposal, in which both forms occur, there are evenly transitional forms between the polished, almost smooth eburnea, ornamented with only a few slight transverse ribs towards the ventral margin, and the strongly ribbed, thick-valved solidula. The outline varies somewhat, the colour is clear-white in almost all the specimens from the Gulf of Siam. Cumng's specimens of eburnea from the Philippines are of a yellowish colour, but otherwise agree entirely with my individuals from the Gulf of Siam.

\section{Corbula (?) mirabilis n. sp.}

(Pl. V, Figs. 35-37).

The shell is squarish-oblong in form, flat, thin-valved and white. 'The umbones are situated towards the posterior end. The prodissoconch is clear, smooth and glossy. Anteriorly the upper margin is straight and passes by a gentle arch into the front margin, which forms a semi-circle. The ventral margin is straight, and parallel with the upper margin. The posterior margin passes in an almost straight line obliquely down from the umbo; a rugged kecl extends right arross the posterior part of the shell from the umbo down to the point at which the ventral and the posterior margins meet. The surface is rough and the lines of growth are coarse and irregular. The interior of the valves is somewhat glossy and the roughness of the surface can here be seen owing to the thinness of the valves. In the hinge there is anteriorly a crater-like depression (probably for the reception of a tooth in the left valve). The margins of this depression have, at the back, a small, pointed tooth and at the front a larger tooth which is continued anteriorly into a long lamella immediately under the upper margin of the valve; beside and somewhat in front of the larger tooth mentioned there are, in addition, upon the upper margin, two tooth-like nodules which project beyond the margin and are visible outside of the shell. Behind the circumscribed depression named is a triangular excision almost immediately under the apex; upon the upper erlge of the thickened posterior margin there is a shallow groove in which, no doubt, the liganent is placed; this groove is limited above by a tooth-like process upon the upper margin which, upon the surface of the shell, resembles a small ear. The front muscle-impression is distinctly visible, but the pallial line only partially; the pallial sinus appears to be wanting.

Long. $11 \mathrm{~mm}$., alt. 5.5 mm., crass. (test. dextr.) $1 \mathrm{~mm}$.

North of Koh Kut, 10 fathoms, mud ( $1 / 2)$.

The above diagnosis is based upon the solitary (probably right) valve obtained, and I refer the specimen, but with great doubt, to the genus Corbula. In spite of 
the dental peculiarities, I am of opinion that it ought most properly to be placed under the family Corbulidae. It will be of interest, when complete specimens are at hand, to ascertain accurately the systematic place of this characteristic form.

\section{Sphenia quadrangularis n. sp.}

(Pl. V, Figs. 38-41).

This shell is squarish-oblong in form, 1lat, white, very thin, hyaline, and glossy. The umbones, which are not very prominent, are situated at about the middle, slightly towards the posterior end. The protoconch is circumscribed as a small, clear, smooth vesicle. The upper side rounds evenly into the anterior end which is continued in a curve to the ventral side which is quite straight. From the umbo a sharp keel extends over the shell down to the posterior part of the ventral side; the ventral margin meets, almost at a right angle, the posterior margin which ascends steeply towards the upper side into which it passes with" rounded outline. The surface is rough and the lines of growth are coarse, especially upon the flat middle part of the shell where the surface towards the ventral side has numerous grooves and stripes. The interior of the valves is glossy, and owing to their thinness the roughness of the surface also occurs on the interior. In the left valve there is a pointed, somewhat triangular cardinal tooth, which is situated in front of and below the apex; this tooth fits into a pit in the hinge-plate of the right valve; this hinge-plate is situated in the front of the apex and there also occurs upon it, in front of the above-mentioned pit, a small nodule, like a rudimentary tooth. The front part of the upper margin in the right valve rises along a short distance, so that it protrudes somewhat above the margin of the left valve. The ligament is internal, the impressions of the adductor muscles, the pallial line, and the pallial sinus cannot be seen.

Long. $10 \mathrm{~mm}$, alt. $5 \mathrm{~mm}$, crass. $3 \mathrm{~mm}$.

The coast of Koh Kahdat (1).

I refer this highly characteristic species with some doubt to the genus Sphenia; when a larger (fuantity of material is at hand (unfortunately only a single dead specimen has been obtained) its place will be ascertained with greater certainty. When EDg. Smitu ${ }^{1}$ writes regarding Sphenia perversa, Blanford, that: - "Mr. Blanford makes a curious mistake with regard to the hinge. He says, "In every respect, except the position of the lamellar tooth in the hinge of the left valve instead of the right, the shell appears to be a true Sphenia." In Mr. BLANFond's figure the "lamellar tooth" is properly depicted in the left valve; in specimens of this species in the British Museum it is also in the left, and in every other species and specimen examined by the writer it is in the same valve," - the reason for this must undoubtedly be sought in the fact that BLANFORD" has seen, in several text-books (e.g. by

1 Annals and Mag. of Natural History, vol. XII, 6 Ser., 1893, p. 279.

: Journ. of the Asiatic Soc. of Bengal, vol. 36, II, 1867, p. 68. 
H. \& A. Adams, ${ }^{1}$ Tryon, ${ }^{2}$ P. Fischer, ${ }^{3}$ and others), the erroneous statement that the characteristic cardinal tooth occurs in the right valve, while, in reality (as correctly stated by Turton, ${ }^{4}$ Forbes \& Hanley, ${ }^{5}$ Edg. Smitr, ${ }^{\circ}$ and others), it is found in the left valve.

\section{Sphenia perversa, Blanf.}

Sphenia perversa, Blanfokd, Journ. of the Asiatic Society of Bengal, vol, 36, p. 1I, 1867, p. 68, pl.3, figs. $4-6$.

Edg. Sмти, Annals and Magaz. Nat. Hist., vol. 12, 6 Ser., 1893, p. 279, No.6, pl. $15 \mathrm{~A}$, fig. 6 .

Between Koh Mesan and Koh Chuen, 25-38 fathoms, stones and shells (1). Koh Chuen, 10-15 fathoms (1). Between Koh Mesan and Cape Liant, 5--9 fathoms (1/2). Coast of Lem Ngob, low tide (4). Koh Chang, low tide (1). North end of Koh Chang, 1-12 fathoms, old coral blocks (12). Gulf at the south end of Koh Chang (6). North of Koh Kahdat, 4-5 fathoms, coarse sand (1). Koh Kahdat, 1-2 fathoms, corals (1).

Long. 2-11 $\mathrm{mm}$.

Distribution:- Delta of the Irawady, Pegu.

Like all Mollusca that live in holes and tunnels, which they themselves have made or which were made in other ways, S. perversa, Blanf., varies greatly in form according to the locality which it inhabits; I think it will scarcely be possible to maintain EDG. SMITH's species S. inaequalis from Singapore; I have specimens of $S$. perversa Blanf, before me with flat left valves and which otherwise almost completely agree with Suru's figure and description of S. inaequalis, but the flat left valve is certainly an individual character only.

\section{Cryptomya elliptica, A. Ad.}

Sphenia elliplica, A. AdaMs, Proc. Zool. Soc. London, XVIII, 1850, p. 88.

Cryptomya - - Annals \& Mag. Nat. Hist., 1868, p. 366.

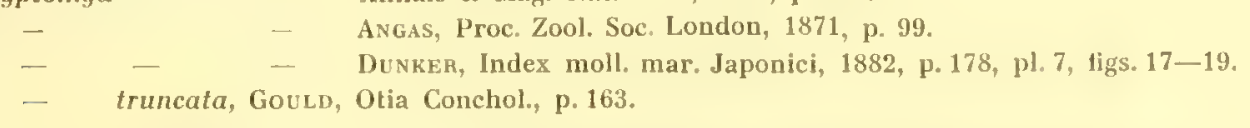

Koh Kahdat $(1 / 2)$. S. of Koh Kahdat, 8-10 fathoms, mud (4/3). N. of Koh Kut, 10 fathoms, mud $(2+4 / 2)$. W. of Koh Kut, 15 fathoms, mud $\left({ }^{6} / 2\right)$.

Long. 4-12.5 $\mathrm{mm}$.

Distribution:- Japan, Sydney.

1 The Genera of recent Mollusca, II, 1858, p. 357.

2 Structural and systematic Conchology, 111, 1881, p. 140.

3 Manuel de Conchyliologie, 1887, p. 1122.

4 Conchylia insul. Britannicarum, 1822, p. 36.

${ }^{5}$ A history of British Mollusca, I, 1853, p. 192.

b loc. cit. p. 279. 


\section{Fam. Solenidae. \\ Solen grandis, Dunk.}

Solen grundis, Dunker, Proc. Zool. Soc. London, 1861, 1).418, No. 1.

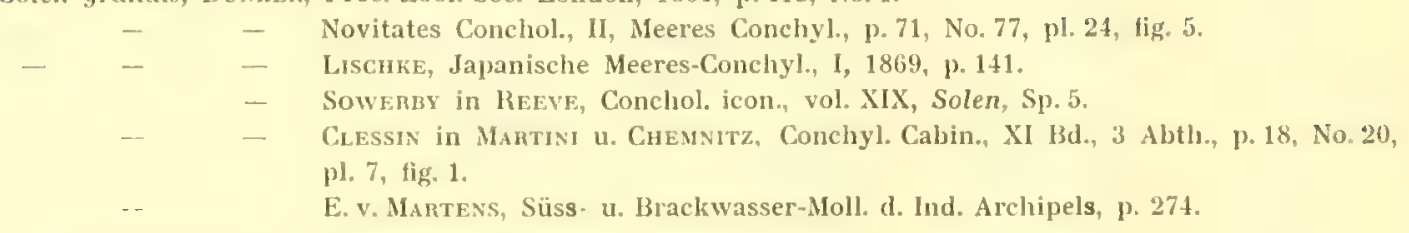

Olf Koh Kam, 10 fathoms, gravel (1/2).

Long. $56 \mathrm{~mm}$.

Distribution:- Philippines, China, Japan.

S. Ceylonensis, Leach $(=S$. intermedius, Koch $=S$. truncalus, Wood (Sow.)), S. curtus, Desm. (= S. abbreviatus, Phil. = S. brevis, Reeve), and S. regularis, Dunk:; come exceedingly near $S$ grandis, Dunk.

\section{Solen corneus, Lam.}

Solen corneus, Lamarck, Hist. nat. d. anim. s. vert., V, 1818, p. 451, No. 2. - éd. 2, VI, p. 54, No. 2.

- - - Delessert, Recueil de coquilles décr. p. Lamarck, 1841, pl. 2, fig. 2.

- - - Prucippr, Abbild. neuer od. wen. gek. Conchyl., III, p. 44, No. 3, pl. 2 , fig. 2.

Sowerby in Reve, Conchol, icon., XIX, Solen, Sp. 19 (non pl. 7, fig. 18 b).

- _ _ Dunkek, Index moll. mar. Japoi1., 1882, p. 173.

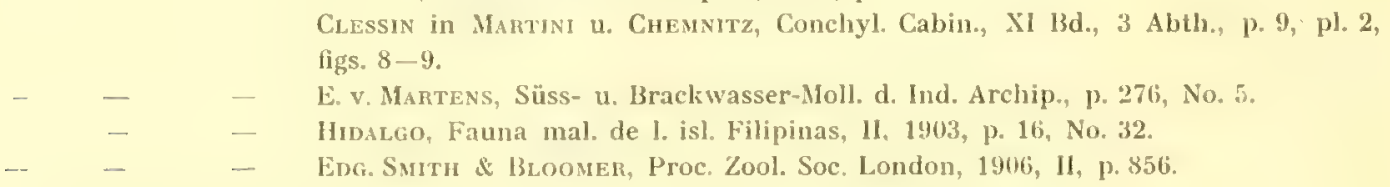

The strand off the Mangrove at the station on Koh Chang $\left(1+{ }^{1 / 2}\right)$.

Long. $31-38 \mathrm{~mm}$.

Distribution: - Karachi, Gulf of Manar, Gulf of Aden, Red Sea, Chuaka Bay (Zanzibar Island), Durban. - Philippines, 'l'schifu (Gulf of Petschili), Japan, Java, Borneo.

This species is recorded with doubt by K. MARTIN" from "the stream-tindeposits" of Blitong (a post-tertiary formation).

Solen linearis, Spengl.

Solen linearis, SPENGLER, Skrivter af Naturhistorie-Selskabet, III, 2 H., 1794, p. 87, No. 3.

- - - Chemitz, Conchyl. Cabin., Xi, 1795, p. 198, pl. 198, figs. 1!31-32.

- - Chemitz, Soweriby in Renve, Conchol. icon., XIX, Solen, Sp. 22.

Clessin in Martini u. Chemnitz, Conchyl. Cabin., XI Bd., 3 Abtlı., p. 23, No. 29, pl. 9, fig. 4.

Spenglek, E. v. MAItTens, Süss- u. Brackwasser-Moll. d. Ind. Archipels, p. 277, No.6.

- C Chemsitz, Hinalgo, Fauna malacol. de I. isl. Filipinas, 1903, II, p. 16, No. 31.

1 Notes from the Leyden Museum, III, 1881, p1. 20 and 22. 
Between Koh Rin and Cliff Rock, 15 fathoms $(1+1 / 2)$. Between Koh Mesan and Cape Liant, 5-9 fathoms ( $/ 2)$. Koh Chuen, 30 fathoms (1/2). West of Koh Kut, 15 fathoms, mud (1).

Long. $15-66 \mathrm{~mm}$.

Distribution:- Nicobars, Ceylon. - Philippines, Japan, Borneo, Java.

\section{Solen vaginoides, Lanı.}

Solen vaginoides, LAMAnck, Hist. nat. d. anim. s. vert., V, 1818. p. 451, No. 3. - éd. 2, VI, p.54, No. 3.

\begin{tabular}{|c|c|c|}
\hline - & - & Delessert, Recueil de coquilles déer. p. Lamarck, 1841, pl. 2, fig. 3. \\
\hline- & - & $\begin{array}{l}\text { Pulippi, Abbild. u. Beschreib. neuer od. wen. gekannt. Conchylien, I, p. 36, } \\
\text { No. } 3 \text {, Solen, pl. 1, fig. } 3 \text {. }\end{array}$ \\
\hline - & - & Solverby in Reeve, Conchol. icon., XIX, Solen, Sp. 23. \\
\hline .. & - & $\begin{array}{l}\text { Clessin in Malitisi u. Chemitz, Conchyl. Cabin., XI Bd., } 3 \text { Abth., p. 16, No. } 17 \text {, } \\
\text { pl. } 7 \text {, fig. 2. }\end{array}$ \\
\hline - & - & Pritchard and Gatriff, Proc, Roy. Soc. Victoria, vol. 16, 1903, p. 99. \\
\hline
\end{tabular}

Between Kolı Mesan and Cape Liant, 5-9 fathoms (1/3). South of Koh Chuen, 30 fathoms, shells $\left({ }^{1 / 2}\right)$. Sound of Koh Chang, 5 fathoms, soft clay $\left({ }^{2} / 2\right)$. Between Koh Kut and Koh Kahdat, 10 fathoms, shells (1/2). West of Koh Kut, 30 fathoms, sand and mud $(1 / 2)$.

Long. 6-38 mm.

Distribution: - Singapore, shallow water (Sv. GAD, ${ }^{4} / 2$ ). "Habite au canal d'Entrecastaux, et à toutes les îles de la Nouvelle Hollande" (LAMArck). South Australia, Tasmania.

The specimens from the Gulf of Siam exactly agree with PulLippis figure and description.

\section{Cultellus scalprum, Gould.}

Solen scalprum, Gould, I'roc. Boston Soc. Nat. Hist., III, (1849) 1850, p. 214 . - Expedition Shells, p. 74. - Unit. States Explor. Exped., Mollusca, p. 388, pl. 33, fig. 502 (non Solen scalprum, King

Pharus - - Conrad, American Journ. of Conchol., III, Append., p. 26.

Cultellus - - E. v. Martexs, Süss- u. Brackwasser-Mollusken d. Ind. Arehipels, 1897, p. 265, No. 2 ,

- subellipticus, Dusker, Proc. Zool. Soc. London, 1861, p. 421, No. 15.

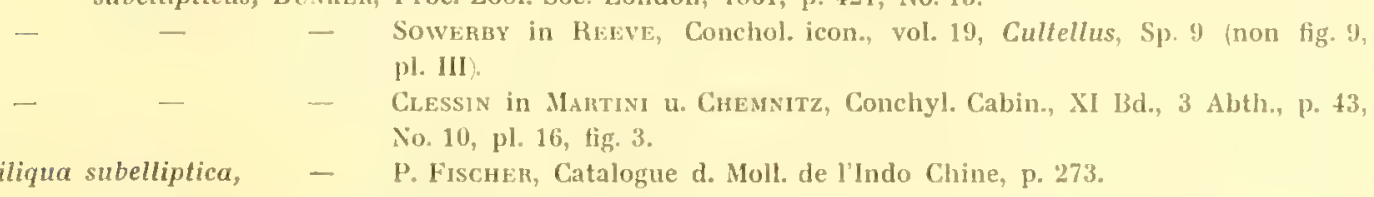

Golfe de Siam (L. MoRLet).

The Danish Expedition to Siam collected no specimens of this species.

D istribution:- Singapore, Strait of Malacca, Poulo Penang, Salang, Mergui Archip. - Java.

Note. Cultellus vitreus, Dunker, was taken in $2-3$ fathoms at Singapore. 


\section{Cultellus (Pharella) ovalis, Dunk.}

Pharella ovalis, Dunken, Proc. Zool. Soc. London, 1861, p. 423, No. 24.

- _ - Novitates Conchologicae, Moll. mar., p. 118, No. 134, pl. 39, fig. 4.

Cultellus - - - Sowerby in ReEve, Conchol. icon., XIX, Cultellus, Sp. 24.

Pharella - - Clessin in Martini u. Chemeitz, Conchyl. Cabin., Xi Bd., 3 Abth., p. 56, No. 7 , pl. 10, fig. 5 .

- $\quad$ - P. Fischer, Catalogue d. Moll. de l'Indo-Chine, p. 273.

Cnltellus (Pharella) ovalis, Dunker, E. v. Martens, Süss- u. Brackwasser-Moll. d. Ind. Archipels, p. 269, No. 7.

Sound of Koh Chang, 3-4 fathoms, soft clay ( $\left.{ }^{1 / 2}\right)$. Coast of Lem Ngob (1/2). Long. $13-68 \mathrm{~mm}$.

"Golfe de Siam" (Morlet).

Distribution:- Singapore.

DunKER's and SowERBY's figures of this species differ rather considerably; my specimens correspond exactly with Sowerby's figure, which also agrees best with the diagnosis.

\section{Cultellus (Ensiculus) cultellus L.}

Solen Cultellus, Linné, Syst. Nat., ed. X, 1758, p.673, No. 27. - ed. XII, p. 1114, No. 37. - Mus. Ludov. Ulricæ reg., 1764, p. 474 , No. 15.

cultellus, - Chemnitz, Conchyl. Cabin., VI, 1782, p. 52, pl. 5, figs. 36-37.

- - - Lamarck, Hist. nat. d. anim. s. vert. V, 1818, p. 453, No. 8. - éd. 2. V1. 1835, p. 56 , No. 8 .

Ensiculus cullellus, Linné, H. Adams, Proc. Zool. Soc. London, XXVIIl, 1860, p. 369.

Cultellus - - Sowerby in Reeve, Conchol. icon., XIX, 1874, Cultellus, Sp. 23.

Ensiculus - - Dunier, Index moll. mar, Japon., 1882, p. 174.

Cultellus - - Clessin in Martinı u. Chemnitz, Conchyl. Cabin., XI Bd., 3 Abtlı., p. 40, No. 6, pl. 3, figs. $7-8$, pl. 14 , fig. 2 .

E. v. Martens, Süss- u. Brackwasser-Moll. d. Ind. Archipels, 1897, p.270, No.8.

- cumingianus, Dunker, Proc. Zool. Soc. London, 1861, p. 422, No. 19.

- Cumingianus, - Sowerby in ReEve, Conchol. icon., XIX, Cultellus, Sp. 7.

- - Clessin in Martini u. Chemnitz, Conchyl. Cabin., Xi Bd., 3 Abth., p. 39 ,

No. 4, pl. 14, fig. 5.

- lividus, _ Proc. Zool. Soc. London, 1861, p. 423, No. 21.

- - Sowerby in Reeve, Conchol. icon., XIX, Cultellus, Sp. 1.

- Clessin in Mahtini u. Chemnitz, Conchyl. Cabin., XI IBd., 3 Abth., p. 40, No. 5, pl. 14, fig. 4.

- concinmus, Dunker, Proc. Zool. Soc. London, 1861, p. 423, No. 23.

(Ensiculus) Philippianus, Dunker, Malakozool. Blātter, 1877, p. 68, No. 4.

Ensiculıs Philippianus, Dunker, Index moll. mar. Japon., p. 174, pl. 7, fig. 23. (Ensiculus Phitippii, 1)unk.). Cultellus Clessin in Martini u. Chemaitz, Conchyl. Cabiu., XI Bd., 3 Abth., p. 36 , No. 1 , pl. 4, fig. 5 .

Ensis asperus, Dunken in schedis, Clessin in Martini u. Chemntz, Conchyl. Cabin., XI Bd., 3 Abth., p. 45 , No. 13, pl. 14, fig. 3 .

Off Koh Kam, 10 fathoms, gravel (1). N. of Koh Kam, 5 fathoms, gravel $(1 / 2)$. Between Koh Mesan and Cape Liant, 5-9 fathoms (1). S. of Koh Chuen, 30 fathoms, 
shells $\left({ }^{1 / 2}\right)$. W. of Koh Chang, 20 fathoms, mud (1). S. of Koh Mak, 5-6 fathoms (1). Koh Kahdat, 1 fathom, sand and corals (3).

Long. 22-56 $\mathrm{mm}$.

Distribution: - Singapore (Danish Exped, to Siam, 2-3 fathoms, coral reef, 2 specimens), Andamans, Tranquebar, Ceylon, Mekran Coast, Persian Gulf, Aden, Red Sea, Suez (50 m., Sturany). - Philippines, China, Japan, Amboina, Java, New Guinea, Torres Strait.

\section{Cultellus (Ensiculus) cultellus L. var. marmoratus, Dunk.}

Cultellus marmoratus, Dunker, Proc. Zool. Soc. London, 1861, p. 423, No. 22.

Ensiculus - _ Index molluscor. mar. Japon., 1882, p. 174, pl. 7, fig. 24.

Cultellus _ _ E. v. Martens, Süss- u. Brackwasser-Moll. d. Ind. Archipels, 1897, p. 271, No. 9 .

- - _ Hıdalgo, Fauna malacol. de 1. isl. Filipinas, II, 1903, p. 23, No. 45.

- (Ensiculus) maculatus, Preston, The Journal of Malacology, vol. XII, 1905, p. 8, pl. 2, fig. 36.

N. of Koh Kahdat, 4-5 fathoms, coarse sand (1). Koh Kahdat, 1 fathom, sand and corals (2).

Long. $45-52 \mathrm{~mm}$.

Distribution:- Ceylon, Red Sea, Suez. - Japan, Philippines (?).

I am convinced that C. marmoratus, Dunk, can scarcely be kept distinct from the highly variable $C$.cultellus (even as a variety), but as the three specimens which I have before me from the Gulf of Siam precisely agree with Dunris's diagnosis and figure, I have given them as varieties. The specimens from Koh Kahdat were laken under the same conditions and in the same locality as C.cultellus; in all the three specimens from the Gulf of Siam, the valves, towards the posterior end, are compressed in the middle, so that when viewed from the gaping, posterior end, the latter has a placentiform outline. The darker colour and the concave dorsal margin are also some of the characteristics of this form.

\section{Siliqua radiata $L$.}

Solen radiatus, Linvé, Syșt. nat., ed. X, 1758, p. 673, No. 28. - ed. XII, p. 1114, No. 38. - Mus. Ludov. Ulrica reg., 1764, p. 474 , No. 16.

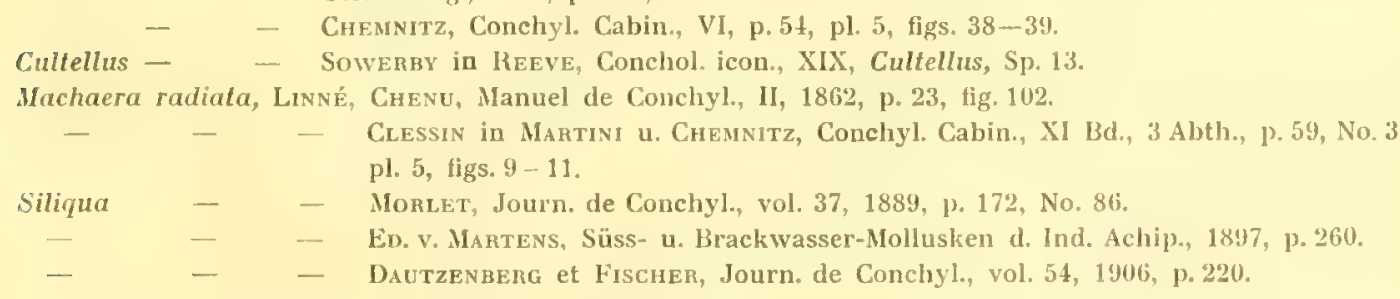

Kampot (Golfe de Siam, L. Morlet).

The Danish Expedition to Siam collected no specimens of this species.

Distribution:- Madras, Tranquebar, Ceylon, Gulf of Manaar, Bombay to Ratnagiri, Mekran Coast. - Annam, Sumatra, Java, Flores, Celebes, Moluccas. 


\section{Siliqua minima, Gmel.}

Minutissima leguminum, Chemnitz, Conchyl. Cabin., VI, 1782, p. 48, pl. 5, fig. 31.

Solen minimus, Gmexis, Syst. Nat., ed. 13, 1790, p. 3227, No. 14.

Aulus - - _ Dunken, Index molluscor. mar. Japon., 1882, p. 175.

Machaera minima, - Clessin in Mairtini u. Chemxitz, Conchyl. Cabin., XI, 3 Abtl., p. 68, pl. 5, tigs. $1-2$.

Siliqua - - - E. v. Mantens, Süss- u. Brackwasser-Moll. d. Ind. Archip., p. 262, No. 3.

Machera - - Hidalgo, Fauna malacol. de I. isl. Filipinas, II, p. 25.

Solen pellucidus, Spexiler, Skrivter af Naturhistor. Selsk., III, 2 H., 1794, p. 97, No. 13.

- albida, Anams \& REEve, Zoology of the voyage of H. M. S. "Samarang," 1848, p. 84, pl. 23, fig. 15. Cullellus albidus, Dunken, Sowełby in Refve, Conchol. icon., XIX, 1874, Cultellus, Sp. 16.

Machaera albida, - Clessin in Martini u. Chennitz, Conchyl. Cabin., XI, 3 Abtlı., p. 65, No. 13. pl. 18, fig. 3 .

The sound of Koh Chang, 3-5 fathoms (fragment).

Distribution:- Malacca, Tranquebar, Bombay. - Philippines, China, Korea, Japan.

Although I am almost convinced of the correctness of the determination, yet, on the basis of the small fragment of a young individual which is at land, it cannot be settled with complete certainty, if the specimen does not possibly helong to the nearly allied species Sil. Winteriana, Dunk.

\section{Novaculina Siamensis, Moṛl.}

Vovaculina Siamensis, L. Mons.et, Journ. de Conchyl., vol. 37, 1889, p. 198, pl. 9, fig. 4.

Solenocurlus (Novaculina) Siamensis, L. Montet, P. Fiscien, Catalogue d. Mollusques de l'Indo-Chine, p. 242.

Novaculina Siamensis, L. Molstet, Mission Pavie Indo Chine, 1879-1895, 1II, 1904, p. 385, pl. 22, fig. 7.

"Marais de Chantakam" (Siam, PaviE).

The Danish Expedition to Siam collected no specimens of this species.

Solecurtus (Macha) rhombus, Spengl.

Solen strigilalus var., Chemsrtz, Conchyl. Cabin., VI, 1782, pp, 60-62, pl. 6, fig. 44.

Rhombus, SPliger, Skrivter af Naturhistorie Selskabet, III Bd., 2 H., 1794, p. 102, Nr. 17. Solecurtus rhombus, SPExgler, E. v. MAnTws, Süss- u. Brackwasser-Moll. d. Ind. Archip., p. 257, No. 2. Macha Quoyi, v. MAkTENS, E. v. Martens u. B. Langkavel, Donum Bismarckianum, 1871, p.61, pl.4, fig. 6 (non S. Quoyi, Deshayes $=$ S. albus, Quoy \& Gaim.).

North of Kol Kahdat, 4-5 fathoms, coarse sand $(1 / 2)$.

Long. $35 \mathrm{~mm}$., alt. $18 \mathrm{~mm}$.

Distribution:- Nicobars, Moluccas, Viti Isls., Kingsmill Isls.

The figure in "Donum Bismarckianum" is not quite good; the outline bolh in SPEngLen's original specimen and in the specimen from Koh Kahdat is more squarish-oval, the anterior and posterior margins being almost rectilinear, obtusely truncated, and lorming rounded angles with the dorsal and ventral margins. 


\section{Solecurtus (Macha) Philippinarum, Dunk.}

Macha Philippinarm, Dunker, Proc. Zool. Soc. London, 1861, p. 424, No. 26.

Solecurtus - - - Sowerby in ReEve, Conchol. icon., XIX, Solecurtus, Sp. 12.

- - - Clessin in Martini u. Chemnitz, Conchyl. Cabin., XI, 3 Abth., p. 90, No. 7, pl. 21 , fig. 8 .

Solenocurtus (Macha) Philippinarum, Duxker, H. Crosse et P. Fisciner, Journ. de Conchyl., vol. 40, 1892. p. 76 , No. 25 .

Solecurtus Philippinarum, Dunker, E. v. MARtens, Süss- u. Brackwasser-Moll. d. Ind. Archip., 1897, p. 256.

- Hidago, Fauna mal. de 1. isl. Filipinas, II, 1903, p. 26, No. 50.

Macha - Dunker, Edg. Smith \& Bloomer, Proc. Zool. Soc. London, 1906, II, p. 855.

Golfe de Siam ("sur le littoral occidental du Cambodge," PaviE).

The Danish Expedition to Siam collected no specimens of this species.

D istribution:- Andamans, Wasin Isl. (East Africa). - Java, Philippines.

In mentioning the genus Macha EdG. SMrtu (loc. cit.) says "HeRmannsen (Indicis

Gen. Malac. Vol. II p. 1) (quotes Macha as described by OKen in 1815; but I have searched in vain in the "Lehrbuch" (Lehrbuch d. Naturg. Vol. III) for any mention of this genus, which should therefore date from 1835." Herrmansen himself had already in the Supplement to "Indic. gen. Malacozoor." 1852 , p. 78 , corrected the date, in his statement concerning OKEN's description of Macha, from 1815 to 1835.

\section{Solecurtus (Azor) emarginatus, Spengl.}

Solen angustior constriclus etc., Chemsitz, Conchyl. Cabin., VI, 1782, p. 62, pl. 6, fjg. 45.

- coarctatus, Gmelix, Syst. Nat., ed. 13, 1790, p. 3227, No. 16 (partim).

Solecurlus (Azor) coarctatus (GMeliN), EDG. Sмитн, Report on the Lamellibranchiata of the Challenger Exped., 1885, p. 79.

Solen emarginalus, Spenglen, Skrivter af Naturhist. Selskabet, III, 2 H., 1794, p. 105, No. 21 (non Synon. Pennant, Brit. Zool., IV, pl. 46, fig. $25=$ S. antiquatus, Pult.).

Macha Scheepmakeri, Dunkel, Zeitschr. f. Malakozool., 1852, p. 56, No. 11.

Azor (Macha) Scheepmakeri, Dusker, Novitates conchol., II, 1869, p. 121, No. 137, pl.39, figs. $10-11$.

Solecurtus Scheepmacheri, - Sowerby in Revve, Conchol. icon., XIX, Solecurtus, Sp. 14

- Scheepmakeri, _ E. v. MAntens, Süss- u. Brackwasser-Moll. d. Ind. Archip., p. 259, No.3. Azor - - Hidago, Fauna malacol. de I. isl. Filipinas, 1903, II, p. 28, No.53.

Solecurtus abbrevialus, Govld, Proc. Boston Soc. Nat. Hist., VIII, 1861, p. 26.

- - - Sowerby in Reeve, Conchol. icon., XIX, Solecurtus, Sp. 6.

- - J. De Morgan, Bull. de la Soc. de France, X, 1885, p. 366, No. 24.

Azor oblongus, Dunken, Proc. Zool. Soc. London, 1861, p. 425, No. 30.

Solecurtus oblongus, "Dorhn," Sowerby in REEve. Conchol. icon., XIX, Solecurtus, Sp. 2.

Azor - Dunker, Hidago, Fauna malacol. de 1. isl. Filipinas, II, p. 27, No. 52.

- solidis, Dunken, Proc. Zool. Soc. London, 1861, p. 425, No. 31.

Solecurlus solidus (non Gray), Sowerby in Rebve, Conchol icon., XIX, Solecurtus, Sp. 3.

W. of Koh Chuen, soft clay and mud ( $/ 2)$. Sound of Koh Chang, 3-5 fathoms, soft clay $\left({ }^{3} / 2\right)$. W. of Koh Chang; $20-30$ fathoms, mud and clay $(5+1 / 2)$. E. of Koh Mak ( $/ 2)$. S. of Koh Kahdat (1/2). Between Koh Kahdat and Koh Kut, 6-10 fathoms, clay mixed with sand $(1+1 / 2)$. North, west and south of Koh Kul, 10-30 fathoms, mud $(9 / 2)$.

Long. 6-36 $\mathrm{mm}$. 
Siam (J. DE Mongan).

Distribution:- Malacea, Poulo Penang, Andamans, Nicobars, Birma, Karikal (Coromandel, Dautzenierg), Mekran Coast, Gulf of Oman, (Gulf of Suez, MAc Andrew?) - Hong Kong, Philippines, Moluccas, New Guinea, Torres Strait.

$S$. coarctatus, Gmelin, which in the course of time has indicated various species, viz. both the European S. antiquatus, Pult., and the East Indian form, and las therefore caused some confusion, ought, in my opinion, to give place to SPENGLER's name emarginatus. GMELIN was evidently not clear with regard to his species, both his diagnosis (true, he says "medio coarclata," but does not mention more closely the characteristic depressed rays upon the middle of the valves), and his statement that "Solen anatinus, Limme" (non S. anatinus L. = Anatina subrostrata, Lam.), in Schröters's "Flussconchylien" "was synonymous with his species, show his uncertainty and that he has confused several species with the species in question, which he evidently did not know by personal observation. SPEngler, in whose colleclion the specimen was contained which CHEMNIT" in 1782 described and figured, gave in 1794 an exhaustive and accurate diagnosis of it under the name of $S$. emarginatus, and I think that this should be preferred to Gmelin's name. I rely upon EDG. Smith's authority in giving S. Scheepmakeri, Dunk., as a synonym of the species under consideration, though it attains a size that is probably not attained by S.emarginatus, Spengl. typ. As far as I can judge from the figure and the brief diagnosis Novaculina andamanensis, Preston," is nothing else but the present species.

\section{Fam. Gastrochaenidae.}

\section{Gastrochaena gigantea, Desh.}

Fistulana gigantea, Deshayes, Encyclop. méth. Hist. nat. d. vers., II, 1830, p. 142.

Gastrochepna - - Traité élém. de Conchyl. (1834), pl. 2, figs. 6-8. Explic. d. planches, p. 2.

Tome I, 2 part., p. 34.
Sowenzy in Reeve, Conchol. icon., XX, 1878, Gastrochana, Sp. 15.

$\begin{array}{cccc}- & - & \text { Sowverky in Revve, Conchol. icon., XX, 1878, Gastrochana, Sp. }\end{array}$

Clessin in Martini u. Chemnitz, Conchyl. Cabil., XI, 4 Abth. a, p. 13, No. 22 , pl. 4, figs. $8-9$.

Rocellaria

EDG. SMrt in The Fauna and Geography of the Maldive and Laccadive Archipelagoes, ed. by Stanley Gardiner, II, p. 626, No. 362.

Gastrochaena Lamצ, Bull. du Mus. d'Hist. Nat. Paris, 1906, p. 207.

Gastrochena lamellosa, EDG. SMith (non Deshayes), Report on the Lamellibranchiata of the Challenger Expedition, p. 28 , pl. 7, lig. 2.

Koh si Chang (1). Koh Cliang, low tide (1). North end of Koh Chang, old coral blocks, 1-12 fathoms (13). South end of Koh Chang, 1 fathom, corals (1). Kolı Kahdat, 1 fathom $(1 / 2)$.

${ }^{1}$ Schnötk̊, Geschichte d. Flussconchylien. Halle 1779, p. 185, pl.9, fig. 17.

2 Mörci, both in Malakozool. Blätter, 1870, p. 110, No.21, and upon the label attached to SPEnGLER's original specimen, has given the name Solen constrictus, Chemn.

${ }^{3}$ Records of the Indian Museum, II, Calcutta 1908, p. 209, pl. 16, fig. 40. 
Long. $5-36 \mathrm{~mm}$.

Distribution: - Singapore, low water, boring in corals (Sv. GAD), Nancowry (Nicobars, Mus. Zool. Hayn.), Maldive Archipelago (EDg. Smin). - Sorong (Tapparone Canefri), Cape York (Challenger). Funafuti Atoll (Hedrey as G. lamellosa, Desh., and with a reference to Eng. SMIth, Challenger Lamellibr. loc. cit. HedLEY adds that the Museum in Sydney has this species from Viti Isls., New Caledonia, Moreton Bay (Queensland) and St. Vincent's Gulf, Lord Hood's Isl. and Mangareva (LAMY).

The specimens from Singapore were found in coral, in which they had made a bottle-shaped hole which was smooth interiorly, and only the narrow part of it which leads to the exterior is partially lined with a thin layer of chalk. ${ }^{2}$ The form which Eog. Smitr figures in Rep. Challenger Lamellibr. (loc. cit.) under the name of lamellosa, Desh., does not correspond with Desinyes's diagnosis of lamellosa; some confusion must certainly, somehow or other, have taken place, I scarcely think I am wrong in putting SmTH's form as a synonym of G. gigantea, Desh. Eng. Smitu says, in his list of the Mollusca from Aden, ${ }^{2}$ regarding Gastrochaena dubia, Penn., "This species undoubtedly occurs in the Red Sea (ruppellii)" at Singapore (indistincta, Desh.) and the Philippines (lamellosa, Desh.). ${ }^{+}$On comparing the types of the three Deshayesian species with specimens of G. dubia, I fail to discover any essential differences." I do not quite agree with EDG. SMith in this; G. gigantea from the Gulf of Siam and from Singapore diflers from G. dubia, Penn., in the stronger and more prominent longitudinal striation over its whole surface, and gigantea attains a larger size than G. dubia, which has been recorded to reach only about $20 \mathrm{~mm}$.

\section{Gastrochaena cymbium, Spengl.}

Gastrochana cymbium, Sprenger, Nye Saml. af d. kgl. danske Vidensk. Selsk. Skrifter, II, 1783, pp. 180-82, figs. 12-17. - Beschäftig. d. Berlin. Gesellsch. Naturf. Freunde, II, 1776, p. 569, pl. IX A, figs. $3-5$.

Chena Cymbinm, _ Rexzius, Diss. sist. nova testaceor. genera, 1788, p. 20.

- - - - Skrivter af Naturhist.-Selskabet, 1II, 1 H., 1793, p. 2t, No. 4, pl. 2, tig. 4.

Lagenula - - BEck, MS. Mus. Univ. Hafn.

Cucurbitula cymbia, _ - T'ryon, Proc. Acad. Nat. Sc. Philadelphia, 1861, p. 54.

Fistulana lagenula, LaMarck, Hist. nat. d. anim. s. vert., V, 1818, p. 436, No. 4. - éd. 2, VI, 1835, p. 31, No. 4.

Hanley, Catal. of rec. biv. shells, p. 3 , pl. 13, fig. 59.

Chena (Cucurbitula) lagenula, Lamarck, Gould, Proc. Boston Soc. Nat. Hist., vol. 8, 1861, p. 22.

Gastrochona lagenula, Lamanck, Sowerby, Thesaur. Conchyl, V, 1887, p. 130, No. 24, pl.470, fig. 18.

1 The cave which G. dubia, Penn., forms is described and figured in: Magazin de Zoologie p. Guérin-Méneville, 1843 (par F. Calluaud), pl.69-71, and in: Bucouor, Dautzenderg et Dollfus, Moll. mar. du Roussillon, 11, 1896, p. 607.

2 Proc. Zool. Soc. London, 1891, p. 395.

${ }^{3}$ Comp.: Stunany, Lamellibranchiaten d. Rothen Meeres, 1899, p. 21.

+ As EDG. Sмrт apprehends this species in the Challenger-Exped. Lamellibr.

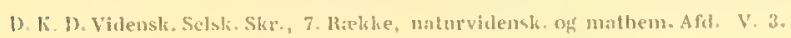


Gastrochana lagenula, Lamanck, Sowerby in Reeve, Conchol. icon., vol. 20, Gastrochana, Sp. 18, pl. 3, fig. 16 (not fig. $18=$ G. ovata, Sow.). ${ }^{3}$

pupina, Deshayes, Proc. Zool. Soc. London, XXII, 1854, p. 326, No. 39.

- Sowerhy, Thesaur. Conchyl., V, 1887, p. 130, No. 25, pl.470, fig. 16.

- - in Reveve, Conchol. icon., vol, 20, Gastrocherna, Sp. 17.

Gastrochaena deshayesi, Sturany, Lamellibranchiaten d. Rothen Meeres, 1899, p. 19, pl.5, figs. 1-7..

NW, of Koh si Chang, 10 fathoms, mud (4). Between Koh Mesan and Cape Liant, 5-9 fathoms (6). Between Koh Mesan and Koh Chuen, 25-38 fathoms (4). S. of Koh Chuen, 30 fathoms, shells (1). W. of Koh Chang, 20 fathoms, mud (1). E. of Koh Mak, 20 fathoms, mud (3). W. of Koh Kut, 15 fathoms, mud (3). Coast of Kols Kut (1).

Long. $12 \mathrm{~mm}$.

Distribution:- Coromandel Coast, Ceylon, Red Sea, Suez. - Hong Kong, Moreton Bay.

Gastrochaena aequabilis, Sluiter, "from Krakalau is closely allied to the present. species. As Spengler's original specimens of G. cymbinm have been at my disposal I am certain of the correctness of the determination.

\section{Fam. Pholadidae.}

\section{Pholas (Monothyra) orientalis, Gm.}

Pholas orienlalis, GMeLIN, Systema Naturae, ed. XIII, 1790, p. 3216, No. 7.

- _ - Lamarck, Hist. nat. d. anim. s. vert., V, 1818, p. 444, No. 2. - éd. 2, VI, p. 44, No. 2.

Dactylina - - Gray, Ann. \& Mag. of Nat. Hist, 2 ser., VIII, 1851, p. 382.

Pholas Orientalis, - Sowerbr, Thesaur. Conchyl., 11, p.486, No. 4, pl. 102, figs.3-4.

Monothyra orientalis, Gmelin, Tnyon, Proc. Acad. Nat. Sc. Philadelphia, 1862, p. 205. - Catalogue of rec. Moll. Pholadacea, p. 3.

Pholas - - ReEve, Conchol, icon., XVIII, Pholas, Sp. 5.

Phragmopholas orienlalis, GMEus, MorteT, Journ. de Conchyl., vol. 37, 1889, p. 173, No. 91.

Pholas (Dactylina) - _ - Clessin in Martivı u. Chemsitz, Conchyl. Cabin., XI Bd., 4 Abth., p. 12 , No. 6 , 12l. 2 , figs. $3-4$.

- Indiae Orientalis, Chesnrtz, Conchyl. Cabin., VIII, 1785, p. 356, pl. 101, tig. 860.

1 On PI. 3 in "Conchologia iconica" the numbers of No. 16 (G. ovata from Panama) and No. 18 (G. lagenula from Ceylon), have been interchanged by a misprint; this has misled Sturany (who did not discover the error), so that he (loc. cit.) las established his species G. Deshayesi upon typical specimens of G. cymbium, Sp. (lagenula, Lam.). It is not surprising that Cuessin should copy this errol in his Monograph, without comparing the diagnoses with the figures, when we recall the uncritical character of his Monographs of Bivalves in: MARTsi u. Chemnitz, Conchyl. Cabinet. Hedcey (Australian Muscum, Sydney. Memoirs III, 1896-1900, p. 508) characterizes CuEssin's Monograph of "The Teredinide" as follows: "Lven worse is an alleged Monograph by CLessin in the Conchylien Cabinet, of which the lext and illustrations disgrace that serial. The latter memoir is absolutely the worst zoological monokraph I have read."

C. P. Suvter, Ueber d. Bildung d. Kalkröhren von Gastrochaena. Natuurk. Tijdschrift v. Nederl Indie, 50 Bd., 1890, pp. 45-60, pl. 1. 
Pholas Siamensis, Spengler, Nye Saml. af Danske Vidensk. Selsk. Skrivter, III, 1788 (1781), pp. 128-38 with pl. (without Latin name). - Skrivter af Naturhistorie-Selskabet, II, 1 H., 1792 , p. 88 , No. 3 .

"Den Siamske Havbugt, for Udlobet af Strommen Queda, hvor den gaaer op til Alastav" (Spengler). Islands in the Gulf of Siam (Morlet).

The Danish Expedition to Siam brought home no specimens of this species.

Distribution: - Tranquebar, Gulf of Manaar, Mouths of the Indus (Karachee, Scinde), Oman. - China Sea.

MörcH ${ }^{1}$ has shown that Scutus (?) abnormis, G. and H. Nevill, from Penang and Chandpur (Bay of Bengal) is nothing else but the accessory dorsal plate ("Protoplaxe") of $P$. orientalis, Gm.

\section{Pholas (Barnea) Australasiae, Gray.}

Barnia Australasice, Grax, Annals and Mag. Nat. Hist., 2 Ser., VIII, 1851, p. 381.

Pholas - - Sowerby, Thesaur. Conchyl., II, p. 488, No. 11, pl. 107, fig. 73.

Barnea - _ Tryon, Proc. Acad. Nat. Sc. Philadelphia, 1862, p. 207.

Pholas - _ ReEve, Conchol. icon., XVIII, Pholas, Sp. 11.

Monlet, Journ. de Conchyl., vol. 37, 1889, p. 173, No. 89.

- (Barnea) Australiasae, Sowerby, Clessin in Martini u. Cinfmitz, Conchyl. Cabin., XI Bd., 4 Abth. p. 21 , No. 18 , pl. 6 , fig. 2 .

Barnea australasiae, Sowerby, Pritchard and Gatliff, Proc. Roy. Soc. Victoria, vol. 16, p. 98.

Between Bangkok and Kampot (Gulf of Siam), MorLet.

The Danish Expedition to Siam brought home no specimens of this species.

Distribution: - "Abundant in Australia" (Sowerny), Victoria (Pritcharo and Gathiff), Spencer's Gulf (South Australia, Angas), Tasmania (Tate and May).

A nearly allied species from Mergui has been described by Phulippr under the name of $P h$. birmanica. ${ }^{3}$ On considering the distribution of $P$. Australasiae, a doubt arises as to the correctness of MorideT's determination.

\section{Pholas (Barnea) sp.?}

The shell of a small Barnea (long. $5 \mathrm{~mm}$.) has been obtained at Koh Kahdat which in form and sculpture somewhat resembles B. parva, Penn. On account of its small size and bad state of preservation I cannot determine it with any certainty.

\section{Pholas (Martesia) striata (L.), Sow.}

Pholas striatus, Linké, Syst. Nat., ed. X, 1758, p.669, No.12. - ed. X11, 1767, p. 1111, No. 22.

- striata, - Sowerby, Genera of rec. and foss. shells, No. XXIII, Pholas, fig. 2. - Thesaur. Conchyl., II, 1855 , p. 494, No. 29, pl. 104, figs. $40-42$; pl. 105 , figs. $43-44$.

- Forbes \& Hasley, Britisl Mollusca, 1, p. 120.

1 Journal de Conchyliologie, vol. 24, 1876, p. 367.

2 Journal of the Asiatic Soc. Bengal, vol.43, pt. II, 1874, p. 28, pl.1. fig. 12.

3 Abbild, u. Beschreib. neuer od. wen. gekannt. Conchylien, III, p. 51, pl. 1, fig. 1. 
Martesia striata, Linné, H. \& A. Adams, Genera of rec. Moll., II, p. 330, pl. 90, fig. 5.

Pholas - - P. Fischer, Journ. de Conchyl., VIII, 1860, p. 337.

Martesia - - Tryon, Proc. Acad. Nat. Sc. Philadelphia, 1862, p. 220. - Catal. of rec. Moll. Ord. Pholadacea, p. 10, No. 13.

- - - Clessin in Martini u. Cheminz, Conchyl. Cabin., Xi I3d., 4 dbth., p. 45, No. 13, pl. 10 , figs. $2-3$ and $7-8$.

Pholas (Mfartesia) striata L., E. v. Martens, Süss- u. Brackwasser-Moll. d. Ind. Archip., 1897, p. 281.

Martesia striata, Linné, Hedley, Australasian Assoc. Adv. Science, VIII, 1901, p. 249, pl. 10 , figs. $10-11$. Pholas pusillus, - Syst. Nat., ed. X, 1758, p.670, No. 14.

- Lignorum, Spengler, Beschäft. d. Berl. Gesellsch. Naturf. Freunde, IV, 1779, p. 167, pl 5, figs. 1-5.

- Skrivter af Naturh. Selsk., II, 1 H., 1792, p. 95, No. 9 (Pholas pusillus).

- nana, Pulteney, Catal. of the Birds, Shells, etc. of Dorsetshire, 1799, p. 27.

- clavata, Lamarck, Hist. nat. d. anim. s. vert., V, 1818, p.446, No.9. - éd. 2, VI, p. 46, No. 9.

- conoides, Fleming, History of Brit. animals, 182S, p. 457.

- falcata, Wood, Gener. Conchology, 1835, p. 84, pl. 16, figs.5-7 (fide Trxon). semicostata, LEA, Proc. Boston Soc. Nat. Hist., 1, 1844, p. 204 (pl. 24, fig. 1).

- terediniformis, Sowerir, Proc. Zool. Soc. London, XVII, 1849, p. 161, No. 5. - Thesaur. Conchyl., II, p. 490, No.18, pl. 108, figs. 97-98, P. Teredinaformis (fide Trion).

Near Koh Samit and Koh Tulu (boring in the swampy layer of cocoanuts which float upon the surface of the water). West of Koh Chang (boring in the fruits of Terminalia Catappa L., which float upon the surface).

Only small specimens as much as $5 \mathrm{~mm}$. in length.

Between Bangkok and Kampot in the Gulf of Siam (MorLet).

Distribution:- Singapore, Pulo Penang, Mergui Archip., Burma (in the trunks of the teak-tree), Madras, 'Tranquebar, Gulf of Manaar, Bombay, Aden, Ins. Zanzibar, Mozambique. - Annam, southern China Sea, Japan, Philippines, Borneo, Batavia and Molluccas (in piles), Arafura Sea, Cape York, Cooktown (Queensland), Sydney, New Caledonia. - East coast of America: South Carolina, Florida, Bermuda Isls., Texas, Greater and Lesser Antilles (Guppy and GabB record it from pliocene formations on Trinidad and in Costa Rica), South America as far as Rio de Janeiro. - The coasts of Europe, e. g. along England and France and in the Mediterranean it has been taken in floating timber and boring in ships.

SPENGLER's original specimens ${ }^{1}$ of $P$. lignorum from 'Tranquebar agree precisely with the specimens of $P$. striata L. from St. Thomas. Several other boring forms such as Naranio lapicida, Chemn., Coralliophaga coralliophaga, Chemn., Modiolaria coralliophaga (Chemn.) Gmel., Lithodomus cinnamomea, Chemn., and others have almost the same wide and peculiar geographical distribution as the present species. In the above-mentioned cocoanut from Koh Samit many quite young, living specimens, $3-5 \mathrm{~mm}$. in length, were found, without Callum, and of the accessory plates only a "Protoplaxe" is found, which in lorm differs from those of the full-grown individuals."

1 In the Zoological Museum of the University of Copenhagen.

"See P. Fischer: "Études sur 1. Pholades," Journ. de Conchyliologie, V1II, 1860, p. 340. 
Pholas (Martesia) multistriata, Sow.

Pholas multistriata, Sowenßr, Thesaurus Conchyl., II, 1849 (1855), p. 494, No. 2S, pl. 104, figs. 35--36. Proc. Zool. Soc. London, 1819, p. 162, No. 8.

$\begin{array}{ccc}\text { Martesia } & - & - \\ \text { Pholas } & - & - \\ \text { Martesia } & - & - \\ - & - & - \\ - & - & -\end{array}$

Troy, Proc. Acad. Nat. Sc. Philadelphia, 1862, p. 218.

ReEve, Conchol, icon.. XVIII, Pholas, Sp. 37.

- Monlet, Jouru. de Conchyl., vol. 37, 1889, p. 173, No. 92.

- P. Fischer, Catalogue d. Moll. de l'Indo-Chine, p. 244.

- Clessin in Martini u. Chemnitz, Conchyl. Cabin., XI Bd., 4 Abth., p. 42 , No. 8, pl. 7 , figs. $6-7$.

Mékong, Gulf of Siam (MorLet).

The Danish Expedition to Siam did not collect any specimens of this species.

Distribution:- Cua-Quen, Annam (Crosse \& Fischer), Turtle's Island, N. coast of Australia (Sowerby).

\section{Pholas (Martesia) Grayana, Leach.}

Photas Grayana, LEACH, MS. Brit. Mus.

- - _ Reeve, Conchol. icon., XVIII, Pholas, 1872, Sp. 46.

Martesia - - Cuessin in Martini u. Chemnitz, Conchyl. Cabin., X1 Bd., 4 Abth., p. 45, pl. 11 , fig. 2.

North end of Koh Chang, old coral blocks, 1-12 fathoms (4/2).

Long. 5-10 $\mathrm{mm}$.

D istribution unknown.

My specimens, which are all small and were taken dead, are without "Callum" upon the anterior end. The striped sculpture upon the front end is very regular, close-set and fine; it is slightly wavy, owing to several grooves which radiate from the umbones.

\section{Pholas (Martesia) rivicola, Sow.}

Pholas rivicola, Soweniy, Thesaurus Conchyl., 11, 1848 (1855), p. 496, No. 33, pl. 108, ligs. 90-91.

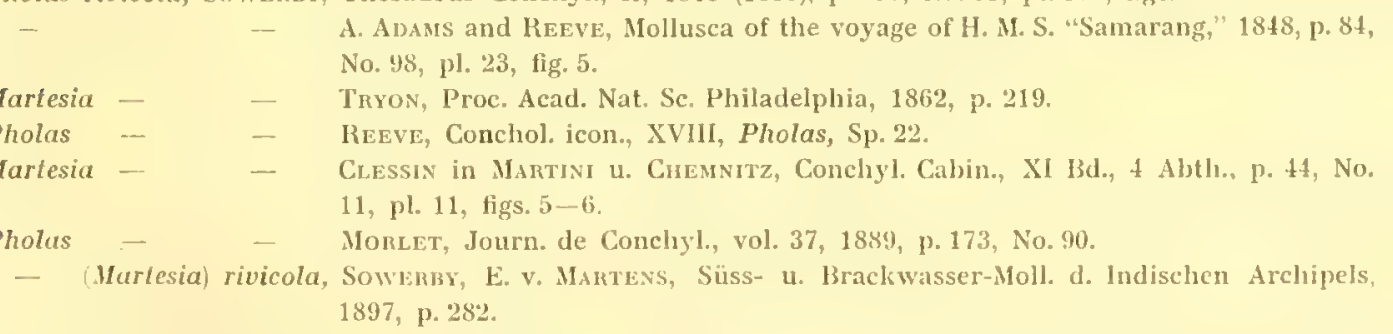

Martesia fluminalis, Buanfond, Journ. Asiat. Soc. 13engal, 1867, vol. 36, p. 67, pl. 3, figs. 1-3 (fide E. v. MARTENS).

Parapholas - _ - Sroliczka, Palcontologia Indica. Cretaceous Fauna of Soutlı-India, III, Pelecypoda, 1871, pp. 20 and 24.

-? - - - Clessin in Martini u. Chemnitz, Conchyl. Cabin., XI Bd., 4 Abth., p. 50, No. 2 , pl. 13 , figs. $4-5$.

Between Bangkok and Kampot (Guif of Siam, Montex), Petshaburi in the Gulf of Siam (v. Martens). 
The Danish Expedition to Siam brought home no specimens of this species.

Distribution:- Mouths of the Irawadi (Buanford), Port Canning (Delta of the Ganges, Stoliczks), Orissa coast, Ceylon (Stoliczka). - Southern China Sea ( $8^{\circ}$ N. lat., vantexs), Borneo (A. Adays), Port Cuming (Australia, Collect. Rolle).

Pholas (Parapholas) quadrizonatus, Spengl.

Pholas quadrizonalus, SPEnglen, Skrivter af Naturhistorie-Selskabet, II, 1 H., 1792, p. 93, No.8, pl.1. figs. $1-3$.

- quadrizonalis, - Sowerby, Thesaurus Conchyl., II, 1855, p. 49:, No. 23, pl. 108, figs. $88-89$.

Parapholas - _ - H. \& A. Adams, Genera of rec. Moll., II, p. 330, pl. 90, fig. 4.

- - - Tron, Proc. Acad. Nat. Sc. Philadelphia, 1862, p. 215.

Pholas quadrizonatus, _- Mörci, Malakozoolog. Blätter, XVII, p. 104. ${ }^{1}$

- quadrizonalis, - REeve, Conchol. icon., XVIII, Pholas, Sp. 38.

Parapholas - - C Clessin in Mantini u. Chemnitz, Conchyl. Cabin., XI Bd., 4 Abth., p. 55, No. 7, pl. 14, fig. 1.

Pholas Incii, SolveruY, Proc. Zool. Soc. London, XVII, 1819, p. 161, No. 7.

- _ _ Thesaurus Conchyl., II, 1855, p.491, pl. 105, figs. $45-16$

Incei, - ReEve, Conchol. icon., XVIII, Pholas, Sp. 30.

Patapholas Incei, - C Clessin in Mantini u. Chemnitz, Conchyl. Cabin., XI Bd., 4 Abth., p. 52, No. 4, pl. 12, figs. $9-10$.

Pholas striatus, Chemnitz (non Linné), Conchyl. Cabin., VIII, 1785, p. 364, pl. 102, figs. 864 -66 (Pholas clavata, Lam. c.).

South-west end of Koh Chang, 1 fathom, coral (1). North end of Koh Chang, old coral blocks, 1 fathom (1).

Long. $13 \mathrm{~mm}$.

Distribution:- Mergui Archip. (v. Martens), Aden (Shopland). - Torres Strait (Sowerby).

One of the specimens from Koh Chang is a young individual; it is entirely without "Callum" and resembles therefore most nearly a Zirphaea."

\section{Fam. Teredinidae.}

\section{Teredo Manni, Wright.}

Kuphus (?) mannii, Wugnt, Transact. Linn. Soc, vol. 25, 1866, p.565, pl. 65, figs. $1-8$.

Nausitoria manni, _ HEver, Australasian Assoc. Advancem. Science, VIII, 1901, p. 248.

Sound of Koh Chang, 5 fathoms. Several very small specimens (about $0.7 \mathrm{~mm}$.) boring in a piece of wood.

Distribution:- Singapore, Cooktown (Queensland).

1 It is due to a mistake that Möncr (loc, cit.) says "Spenglen citirt mit Unrecht Chemn. f. 864-66, die eine Martesia ist," as it is the same specimens from the collection of Spengler, which CHEMnitz 1785 describes and figures (under the name of $P$. striatus L.?) and Spenglel afterwards (1792) describes as $P$. quadrizonalus. These specimens are still in existence in the Museum of the University of Copenliagen.

2 vide: P. Fischer, Études sur 1. Pholades, Journ. de Conchyliologie, VII, pp. 173-74. 
On account of the small size of the specimens the determination is somewhat uncertain. The "palettes" bear a great resemblance to the figures by Wright (loc. cit.).

Note. At Singapore in shallow water a solitary valve of a Nausitora has been taken (by Sv. Gad), probably N.edax, Hedley (Proc. Linn. Soc. New South Wales, IX, 1894, p. 501, pl.32, figs. $1-5$ ), but as its palettes were not found, the determination is uncertain.

\section{Fam. Pandoridae. \\ Coelodon elongatus, Carp.}

Coelodon elongatus, Carpenter, Proc. Zool. Soc. London, 1864, p.600, No. 3.

$\begin{array}{ccc}- & - & \text { Edg. Smith, Rep. Lamellibranchiata of the "Challenger" Exped., p. 62. } \\ \text { Pandora elongata, } & - & \text { G. B. Sowerby in ReEve, Conchol. icon., vol. 19, 1874, Pandora, S. } 4 .\end{array}$

Sound of Koh Chang, 5 fathoms, soft clay $(1+2 / 2)$.

Long. $11-16 \mathrm{~mm}$.

D istribution:- China, Borneo, Flinders Passage (North Australia).

The present species is very characteristic on account of its flatness, but like all the species belonging to the genus Pandora it varies considerably in form. Hedley evidently does not know Sowerby's figure in ReEve's Conchol. icon. as he calls it (Proc. Limn. Soc. New South Wales, vol. 31, 1906, p. 473) an "unfigured species" and (loc. cit. pl.37, fig. 16) gives a figure of a form from Mast Head Reef, Queensland, under the name of C. elongatus, Carp., which, however, scarcely is Carpenter's species.

Note. Myodora trigona, Reeve, has been taken (by Sv. GAD) at Singapore in shallow water.

\section{Fam. Anatinidae.}

\section{Anatina anatina L.}

Solen anatinus, Linvé, Syst. Nat., ed. X, 1758, p. 673, No. 30. - ed. XI1, 1766, p. 1115, No. 40. - ed. XIII, p. 3225, No. 8. - Museum Ludov. Ulrice reg., 1764, p. 475, No. 18.

- - - - Chemnitz, Conchyl. Cabin., VI, 1782, p.62, pl.6, fìgs.46-48.

Anatina subrostrata, LAMARGK, Hist. nat. d. anim. S. vert., V, 1818, p.463. - éd. 2, 1835, VI, p. 78.

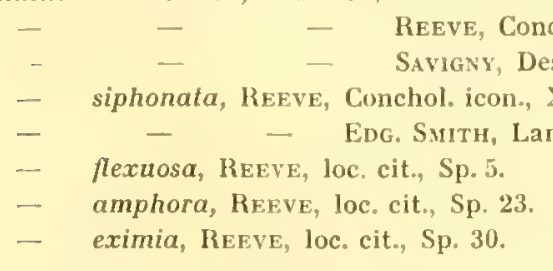

N. of Koh Kam, 5 fathoms, gravel (1). Koh Chuen, 30 fathoms (2). Between Koh Mesan and Cape Liant, 9 fathoms (2). S. of Koh Tulu, 10 fathoms, mud mixed with sand (1). Off Tung Kaben, 6 fathoms, mud mixed with sand 2). Sound of Koh Chang, 3-5 fathoms, soft clay (many fragments). Between Koh Kahdat 
and Koh Kut, 6 fathoms, clay mixed with sand (1). W. of Koh Kut, 15 fathoms, mud (2). Ofl Koh líut, 5 fathoms (fragments).

Long. $26 \mathrm{~mm}$. (several of the fragments have belonged to larger specimens).

D istribution: - Singapore (Danish Exp. to Siam, 2 specimens), Nicobars, Ceylon, Mekran Coast, Aden, Red Sea, Suez, Suez Canal. - Philippines, Japan (A. flexuosa), Borneo, Flores.

The species here under consideration varies considerably, especially with regard to the form and the development of the rostrum; and many species of the gen. Anatina will certainly in the course of lime be withdrawn owing to their having been based upon entirely individual characters. The greater part of the specimens from the Gulf of Siam resemble most nearly Rerve's figure of A. eximia.

\section{Fam. Clavagellidae.}

\section{Brechites dichotomus, Chenu.}

Aspergillum dichotomum, CHexv, Illustrations conchyliologiques (1843-45), Aspergillum, p. 3, p]. 2, tig. 6. Brechites dichotomus, - H. H. ADAMs, Genera of rec. Moll., II, 1858, p. 339.

Aspergillum dichotomum, - Reeve, Conchol. icon., XII, 1860, Aspergillum, Sp.9.

Penicillus dichotoma, - Tryos, Proc. Acad. Nat. Sc. P'hiladelplia, 1861, p. 59, No. 2.

Aspergillum dichotomum, - Ciessin in Martixi u. Chemnitz, Conchyl. Cabin., XI Bd, 4 Abth. A, p. 30, No. 9, pI. 12, fig. 2.

Koh Lan, 30 fathoms, mud (1). Kón Chuen, 30 fathoms (3). N. of Koh Kahdat, 1-5 fathoms, coarse sand (1). Koh Kahdat, 1 fathom, sand (1). S. of Koh Mak, 5-6 fathoms (2).

All the specimens collected were fragmentary.

Distribution:- Singapore (Cumns), Gulf of Manaar ('Thurston).

Tryon (loc. cit.), undoubtedly correctly, considers $B$. disjunctus, Desh., to be synonymous with B. dichotomus, but several other of those species which have been established ought probably also to be abolished; thus GraY has united under the name of Penicillus aquaria, Burr.:- Aspergillum dichotomum, Chenu, semifimbriatum, Chenu, sparsum, Sow., javanum, Gray (non LAm.).

\section{Order Septibranchiata.}

\section{Fam. Cuspidariidae.}

Neaera Singaporensis, Hinds.

Necra Singaporensis, Hinds, Proc. Zool. Soc. London, XI, 1843, p. 77.

IV. of Koh Chuen, soft clay and mud ( $\left.{ }^{7} / 2\right)$. W. of Koh Chang, 30 fathoms $\left({ }^{1 / 2}\right)$. Kolı Kahdat ( $(/ 2)$. N. of Koh Kut, 10 fathoms, mud ( $\% / 2)$. Between Koh Kahdat

1 Proc. Zool. Soc. London, 1858, p. 312. 
and Koh Kut, 6-10 fathoms, clay mixed with sand and shells (\%). W. of Koh Kut, 15 fathoms, mud (1).

Long. $4-9 \mathrm{~mm}$.

Distribution: - Singapore.

Neaera (Cardionya) pulchella, H.Ad., ${ }^{1}$ and

N. Gouldiana, Hinds, ${ }^{2}$ are closely allied to

the present species.
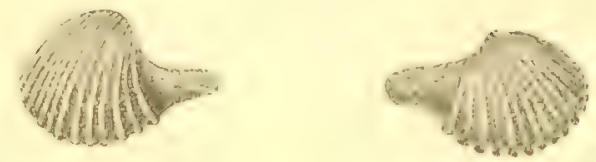

Neaera Singaporensis, Hinds.

\section{Neaera rosea, Hinds.}

Neara rosea, Hinds, Proc. Zool. Soc. London, XI. 1843, p. 78.

- - - Mollusca of the Voyage of H. M. S. "Sulphur," 1845, p. 70, No. 296, pl. 20, fig. 20.

- - Hibalgo, Fauna malacol. de 1. isl. Filipinas, 1903, p. 43, No. 88.

West of Koh Kut, 30 fathoms, sand and mud (1/2).

Long. $5 \mathrm{~mm}$, alt. $3 \mathrm{~mm}$.

Distribution:- Philippines, New Guinea.

I do not doubt that the small left valve which I have before me should be referred to $N$. rosea, Hinds, in spite of the fact that the beak is not of a rose-colour.

I Proc. Zool. Soc. London, 1870, p. 789, pl. 48, fig. 4 .

2 Proc. Zool. Soc. London, 1843, p. 77.

\section{ERRA TA}

Page 45 , line' 6, for Busch read Bush.

- 128, - 42, - Lamellibranchiata - Lamellibranchiaten.

- 134, - 9, - peronata - personata.

- 144, - 34, - T. variegatus, Sow. - T. variegatus, Hanl. 


\section{Index.}

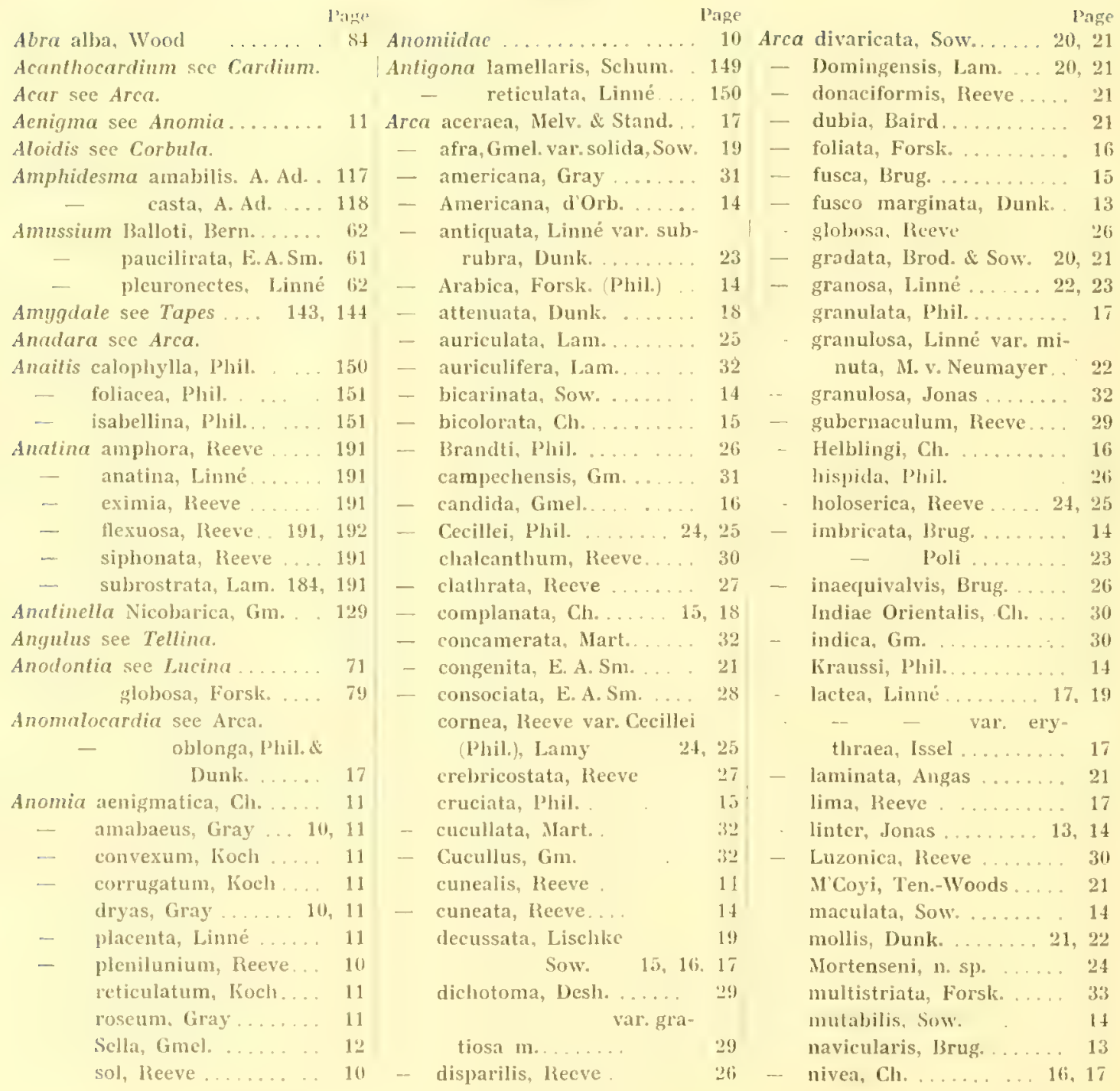




\begin{tabular}{|c|c|c|c|c|c|}
\hline & l'age & & Page & & l'age \\
\hline Arca & nodifera, v. Mar & Artemis trigona, Reeve & 152 & Cardita & radula, Reeve...... 67 \\
\hline- & oblonga, Dunk.. & Asaphis arenosa, Rumph. & 114 & - $s$ & subaspera, Lam. . . . . \\
\hline & - Phil. & coccinea, Martyn & 113 & $-v$ & variegata, Brug. . . . . . \\
\hline - & obliquata, Gray & deflorata, Linné & 113 & Carditello & la infans, E. A.Sm... \\
\hline - & olivacea, Reeve. & dichotoma, Anton & 114 & - & pulchella, n. sp.... \\
\hline - & parva, Sow. . . . . . . . . . & rugosa, Lam. .... & 114 & - & pusilla, n. sp...... \\
\hline - & paucigranosa, Dunk. ... & - violascens, Forsk. ... & $11: 3$ & - & Torresi, E. A. Sm. \\
\hline 一 & pectunculiformis, Dunk. . & Aspergillum dichotomum,Chenu & 192 & Carditida & $a c, \ldots \ldots \ldots \ldots \ldots$ \\
\hline - & pectunculus, Linné . . . . . & Astartidae & lis & Cardium & a Adamsi, Reeve..... 166 \\
\hline - & Petersi, Dunk. ........ & Alaclodea sce Mesodesma & 122 & - & amboinense, Gm.... 32 \\
\hline - & pholadiformis, C. B.Adams 2I & Aulus minimus, Gm. . . & 182 & - & Annae, P'ilsbry ..... 162 \\
\hline 一 & pisolina, Lam.... . . 19, 20 & Avicula see Pteria. & & - & apertum, Ch. ..... 162 \\
\hline & plicata, Ch. $\quad 20,21$ & Azor coarc & 183 & - & eve..... 161 \\
\hline - & pulchella, Dunk. ....... 23 & emarginatus, Spengl. & $1 \times 3$ & - & Asiaticum, l3rug. .... 159 \\
\hline - & - Reeve $\ldots \ldots$ & - oblongus, Dunk. ... & 183 & - & Australe, Sow....... 163 \\
\hline - & pusilla, Sow. . . . . . . . & Scheepmakeri, Dunk. ... & 183 & - & Carditaeforme, Reeve 165 \\
\hline - & pygmaea, H. Adams .... . & - solidus, Dunk. . . . . . . . & 183 & - & coccinea, Martyn ... 113 \\
\hline - & reticulata, Ch. ........ & Barbatia see Arca. & & $=$ & ngl. 159,163 \\
\hline - & revelata, Desh... . . . . . . & Barnea sp.? . . . . . . . . . . . & 187 & & Dupuchense, Reeve 160,161 \\
\hline - & rhomboidalis, Cli. ...... & - Australasiae, Gray .... & 187 & & fimbriatum, Wood... 159 \\
\hline - & Rodatzi, Dunk. . . . . . . . & - parva, Penn... _. & 187 & & Mavum, Linné ..... 160 \\
\hline - & rotundicostata, Heeve ... & Bellucina. $\quad$.. & 78 & 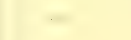 & fragum, Limné...... 165 \\
\hline - & Sabinae, Morl. . . . . . . . & Botula see Lithodomus... & 42 & & - $\quad-\quad$ var. \\
\hline - & scapha, Ch........... 24 & Brachyodontes & & & carinata m. 165 \\
\hline 一 & sculptilis, Reeve ..... 16, 19 & Bens. (Reeve) & 39 & & - Linné var. \\
\hline - & semitorta, Lam........ 31 & subramosus, & & & Sueziense, Issel . . . 158 \\
\hline - & Siamensis, n. sp. ....... & $\mathrm{Ha}$ & 38 & 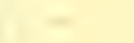 & Hungerfordi, Sow... 163 \\
\hline - & signata, Dunk. . . . . . . 14 & Brechites dichotomus, Chenu. & 192 & - & rix, Reeve ..... \\
\hline - & solida, Sow......... 19, 20 & - semifimbriatum, Chenu & 192 & - & imbricatum, Sow. ... 166 \\
\hline - & squamosa, Lam...... 20, 21 & sparsum, Sow. ...... & 192 & & um, Sow. ... 161 \\
\hline - & subquadrangula, Dunk. . 13 & javanum, Gray. & 192 & $x^{2}$ & lamellatum, Spengl. 159 \\
\hline - & subrubra, Dumk. . . . . . . & disjunctus, Desh. & 192 & & latum, Cl........ 158 \\
\hline - & rica, Reeve ....... . & Bucardium see Cardinm. & & & lima, Spengl....... . 159 \\
\hline - & tenella, Reeve ........ & Byssoarca see Arca. & & & Iobulatum, Desh.... 164 \\
\hline - & torta, Stcenstr. . . . . . . & Caecella Cumingiana, Desh.... & 130 & & maculosum, Sow..... 161 \\
\hline - & tortuosa, Linné . . . . . . . & Callianassat $\quad \ldots$. & 85 & & magnum, Ch. ...... 160 \\
\hline - & trapezina, Lam......... & Callista citrina, liorlicbr. & 132 & - & Inultispinosum, Sow. 160 \\
\hline- & Troscheli, Dunk....... & im........ & 133 & & muticum, Reeve.... 162 \\
\hline 一 & umbonata, I.am........ 14 & -. intlata, Sow... & 131 & - & раругасеum, Ch..... 162 \\
\hline - & uropygomelana, Bory ...24 24 & Callocardia Deshayesi, Pfr. var. & 133 & $=$ & pectiniforme, Born 160,161 \\
\hline- & velata, Sow. $\quad 16,17$ & - guttata, A. Ad.... & 133 & & m, Recve.... 163 \\
\hline - & vellicata, Reeve ....... 26 & Capsa deflorata, Limné & 113 & & retusum, Linné .... 164 \\
\hline - & Zebuensis, Reeve ..... 19, 20 & - eflorata, d'Orb. & 113 & - & rugatum, Gron. .... 162 \\
\hline Arcia & lae $\ldots \ldots \ldots \ldots \ldots \ldots \ldots$ & - rugosa, Lam....... & 113 & & rugosum, Lam. . 160, 161 \\
\hline Arco & pagia see Tellina. & Capselía violacea, Reeve. & 117 & - & setosum, Redf. ..... 157 \\
\hline Argi & 'a see Arca...... & Capsula rugosa, Lam. ..... . & 113 & & Sinense, Sow. ...... 160 \\
\hline Arter & mis contusa, Reeve... & Cardiidae .......... & 1.57 & & subretusum, Sow.... 164 \\
\hline - & cretacea, Heeve... . & Cardilia inermis, Desh.... & 121 & - & Sueziense, Issel..... 158 \\
\hline - & exasperata, PJil. . & Cetrdiliedate & 121 & - & tenuicostatum, Lam. . 164 \\
\hline- & laminata, Heeve .... 152 & Cardiomya pulchella, H.Ad. & $1 ! 13$ & & transcendens, Melv. \& \\
\hline- & pubescens, Phil...... 155 & Cardila calyculata, Lam... & 67 & & Stand. . . . . . . 161 \\
\hline & simplex, Hanl. . . . & ctylus, Brug. ... & 70 & -- & unedo, Linné .... \\
\hline
\end{tabular}




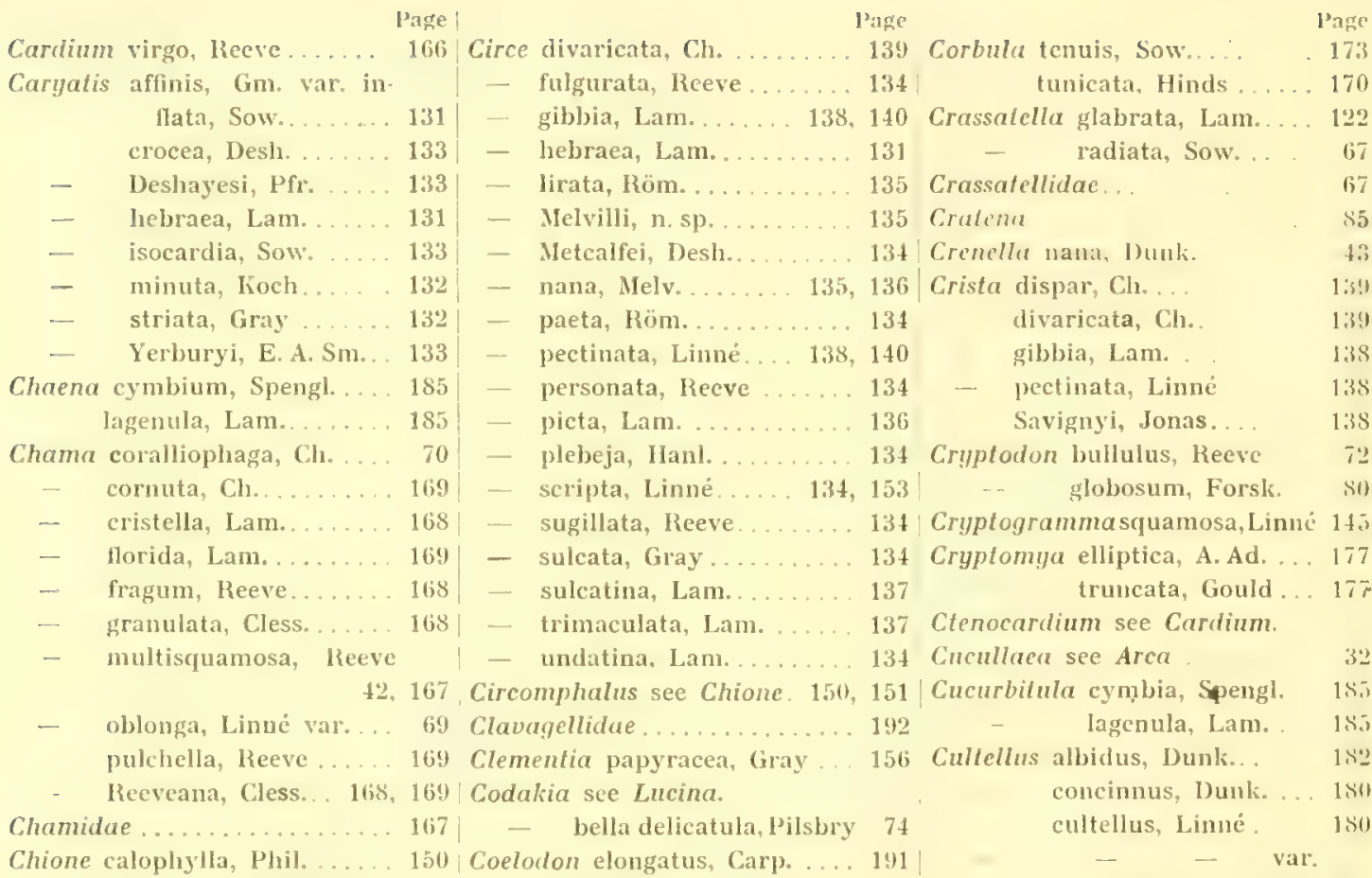

Chione calophylla, Phil...... 150 |Coelodon elongatus, Carp. .... 191 Cochinensis, Sow..... 148| Coralliophaga carditoidea,

- cmbrithes, Melv.dStand. 152

- foliacea, Phil........ 151

- hizenensis, Pilsbry.... 147 imbricata, Sow....... 148

- isabellina, Phil. ...... 151

- Jukesi, Desh. ........ 151

Lamarcki, Gray . . . . . 150

- Lamellaris, Schum..... 149

- lionata. E. A.Sm. . . . . . 14!

- marica, Linné (Sow.) 146, 147 micra, Pilsbry....... 148 recognita, E. A. Sm. 146, 147 reticulata, Limé ...... 150 scabra, Hanl.

- Siamensis, 11. spr.

striata, Gray. . subnodnlosa, Hanl.... 117|

- toreuna, Gould, ....., 151|

Chlamys see Pecten......... 61 l

Chloromya see Mytilus.

Ghoristodon divaricatum, Ch.. 157/ lapicidum, Ch. ... 157 |

Circe aequivoca, Sow........ 139 amica, E. A. Sm. ....... 136 Artemis, Desh. 134

- dispar, Ch....
Blaiแv. 71 coralliophaga, Ch. 70,188

dactylus, Brug. . 70

- laminata, Reeve. 71

- lithophagella,

1)unk. 71 striolata, H. Ad. 71

Corbula arcacformis, $\mathrm{n}, \mathrm{sp} . \ldots 172$ crassa, Hinds ....... 169 churnea, Hinds, 174, 175 crythrodon, Lam. .... 17 fortisulcata, E. A. Sm. 174 isomeros, Hinds...... 123 Kjaeriana, C. 13. Ad... 172 lineata, n. sp....... 171 Macgillivrayi, E. A. Sm. 170 (?) mirabilis, n.sp. . 175 monilis, Hinds. . . . 174 pallida, Hinds ...... 171 rugifera, A. Ad. (Sm.) 173 scaphoides, Hinds 170,171 solidula, Hinds ..... 174 subquadrata, Melv..., 172 sulcata, Lam. ....... 174 Taheitensis, Lam. . . . 173 marmoratus, Dunk. 1is Cumingianus, Dunk. 180 lividus, 1)unk...... 1so marmoratus, Dunk. . 181 ovalis, Dunk. . 180 Philippianus, Bunk. . 180 radiatus, Linné . $1 \& 1$ scalprum, fiould . 17! subellipticus, Dunk. . 17! vitreus, bunk. 17!) Cunearca see Arca 2!! Cuncus sce Tapes.... 11:141 Cyclas globosa, Forsk si Cyclina elegans, H. dd. 1.i. Ceppricardia angulata, Lam... $6 !$ coralliophaga, Ch. 70 gracilis, shuttlew. 71 Hornbeckiama,

d'Orb. 71 rostrata, Lam. ... 70 vellicata, Reeve.

Cipprinidae ...... tis

Cinrenoida oblonga, Hanl. . Sil

Cytherea aftinis, Gm. var. inllata, Sow. ........... $1: 31$ clordata, Röm...... 133 citrina, Lam. .... 1:32 


\begin{tabular}{|c|c|c|c|c|}
\hline \multirow[b]{2}{*}{ Cytherea } & $\begin{aligned} \text { l’age } & \end{aligned}$ & & Page & l'age \\
\hline & crocea, Gray ....... 133 & Donax australis, Lam. .. & 120 & Ensiculus marmoratus, Dunk. 181 \\
\hline - 1 & Deshayesi, Pfr..... 133 & bicolor, Gm. (Lam.) & $1 \geq 0$ & Pliilippianus, Dunk. 180 \\
\hline- & dispar, Ch. ....... 139 & _ liömer & 120 & - Plilippii, Dunk. .... 180 \\
\hline - & divaricata, Cl. . ... 139 & compressus, Lam. & 121 & Ensis asperus, Dunk....... \\
\hline - & erythraea, Jonas . . . 134 & cuneatus, Linné .. 120, & 121 & Ervilia australis, Angas \\
\hline - & exasperata, Phil. .... 15: & Deshayesi, Dunk.... & 121 & - bisculpta, Gould \\
\hline- & gibbia, Lam. ...... 138 & Dysoni, Deslı. . . . 119, & 120 & - incolor, Desh.... \\
\hline- & hebraea, Lam. ..... 131 & - Lischke... & 119 & Erycint \\
\hline$\ldots$ & a, Sow. ...... 131 & Essingtonensis, Desh. & 112 & - Cycladiformis, Desh. . \\
\hline - & isocardia, Sow..... 133 & euglyptus, Dunk.... & 121 & rotunda, Desh. \\
\hline - & lusoria, Ch. ...... 130 & faba. Ch. & 121 & Erycinidae . ......... \\
\hline - & lyrata, Sow. ...... 131 & granosus, Lam.... 120. & 121 & $\operatorname{Ery} x \ldots \ldots \ldots \ldots \ldots \ldots \ldots \ldots \ldots$ \\
\hline - & inné $\ldots . .130$ & Römer & 120 & Enlamellibranchiata ....... 62 \\
\hline & ta, Koch . . . . . 132 & - Zeleb. & 121 & Fabulina see Tellina. \\
\hline - & pacta, Röm. ...... 134 & incarnatus, Cls.. & 119 & Filibranchiata ........... 10 \\
\hline & pectinata, Limné.... 139 & Irus, Linné .... & 156 & Fistulana gigantea, Desh..... 184 \\
\hline - & petechialis, Lam. .... 130 & muricata, Linné. & 119 & - lagenula, Lam...... 185 \\
\hline - & , Lam. . . . . . 136 & nitidus, Desh.... & 120 & Fossularca see Arca. \\
\hline - & ja, Hanl. . . . . 13! & ohscura, Desh. & 120 & Fragum see Cardium. \\
\hline- & scens, Phil. . . . . 155 & radians, Lam.......... & 121 & Gafrarium navigatum, Hedl... 133 \\
\hline - & ta, Linné .... 73 & Reeve \& Sow. & 121 & Galeomma angusta, Desh. .... 88 \\
\hline$-\cdots$ & ranella, Lam. ...... 138 & radiata, Spengl. . & 121 & argentea, Desh..... \\
\hline- & Savignyi, Jonas ..... 138 & granosus, Dunk. & 119 & chloroleuca, Deslı. . \\
\hline & scripta, Linné. . . . 13t & splendens, Dunk. & 121 & macrochisma, Desh. \\
\hline - & striata, Gray . . . . . 132 & Dosina Lam & 150 & Galeommidae............. \\
\hline- & am. 137,138 & Dosinia $\mathrm{Br}$ & 153 & Gari see Psammobia. \\
\hline - & 1a, Recve ..... 152 & - biscocta, Reeve... & 155 & Gastrochaena aequabilis, Sluiter 186 \\
\hline - & aculata, Lam... . 137 & a, lieeve.... & 155 & - cymbium, Spengl. 185 \\
\hline & Hanl...... 131 & usa, Re & 154 & esi, Stur. . 186 \\
\hline - & Verburyi, E. A.Sm... 133 & ve $\ldots$. & 154 & dubia, Penn.... 185 \\
\hline Dactylina & r orientalis, Gm.... 186 & , A. & 153 & gigantea Desh. .. 184 \\
\hline Davila & rassula, Desh....... 123 & emnice, A. Ad. .. & 155 & indistincta, Deslı. 185 \\
\hline Dione c & ocea, Desh. ........ 133 & exasperata, Phil. ... & 153 & lagenula, Lam. 185, 186 \\
\hline & cens, Reeve. . . . 133 & i, Phil... & 155 & lamellosa, Desh.. 185 \\
\hline - & tlata, Sow. . . . . . . 131 & Hanleyana, H.\& A. Ad. & 154 & E.A.Sm. 184.185 \\
\hline$\ldots$ & inuta, Koch........ 132 & eve... & 152 & ovata, Sow..... 186 \\
\hline - str & iata, Gray ....... 132 & s, Köm... & 155 & pupina, Desh.... 186 \\
\hline Diplodont & ta amboinensis, E. A. & prostrata, Linné & 153 & - $\quad$ Rüppelli, Desh. . 185 \\
\hline & st1................. & scens, Phil. & 155 & Gastrochaenidae ........... 184 \\
\hline- & bullata. Dunk. .... 79 & scabriuscula, Reeve. & 155 & Gouldia delecta, A. Ad. ...... lis \\
\hline - & conspicua, E. A.Sm. 79 & simplex, A. Ad........ & 154 & Gregariella see Modiolaria. 44,45 \\
\hline - & ethima, Melv. \& & Singaporensis,H.\&A.Ad. & 154 & IIecuba see Donax......... \\
\hline & Stand. 78 & stria & 154 & Hemicardium carditacforme, \\
\hline - & globosa, Forsk. 72, & trigon & 152 & Reeve 165 \\
\hline & 79,80 & Eastonia Aegyptiaca, Cl. & $12 !$ & fornicatum. Sow. 165 \\
\hline - & oblonga, Hanl. ... 80 & Nicobarica, (im & $12 !$ & fragum, Linné 158,165 \\
\hline - & rotundata, Mont... 78 & Electroma see Pteria.. & 46 & var. \\
\hline- & Savignyi, Vaill. . 79, 80 & Elizia orbiculata, Wood & $\mid 161$ & carinata $\mathrm{m} . . .165$ \\
\hline Divaricell & lla perparvula, Dall . 76 & orbicularis, (Wood) Bertin & 116 & atum,Sow: 166 \\
\hline & 1e $\ldots \ldots \ldots \ldots \ldots \ldots$ & Ensiculus cultellus, Linné ... & 180 & retusum, Linnc 164 \\
\hline Donacilla & $a$ see Tellina.... 103, 105 & & & \\
\hline
\end{tabular}

Donax acuticarinatus, Sow.,. 119 marmoratus, Dunk...... 181

Dantzenb. 165 


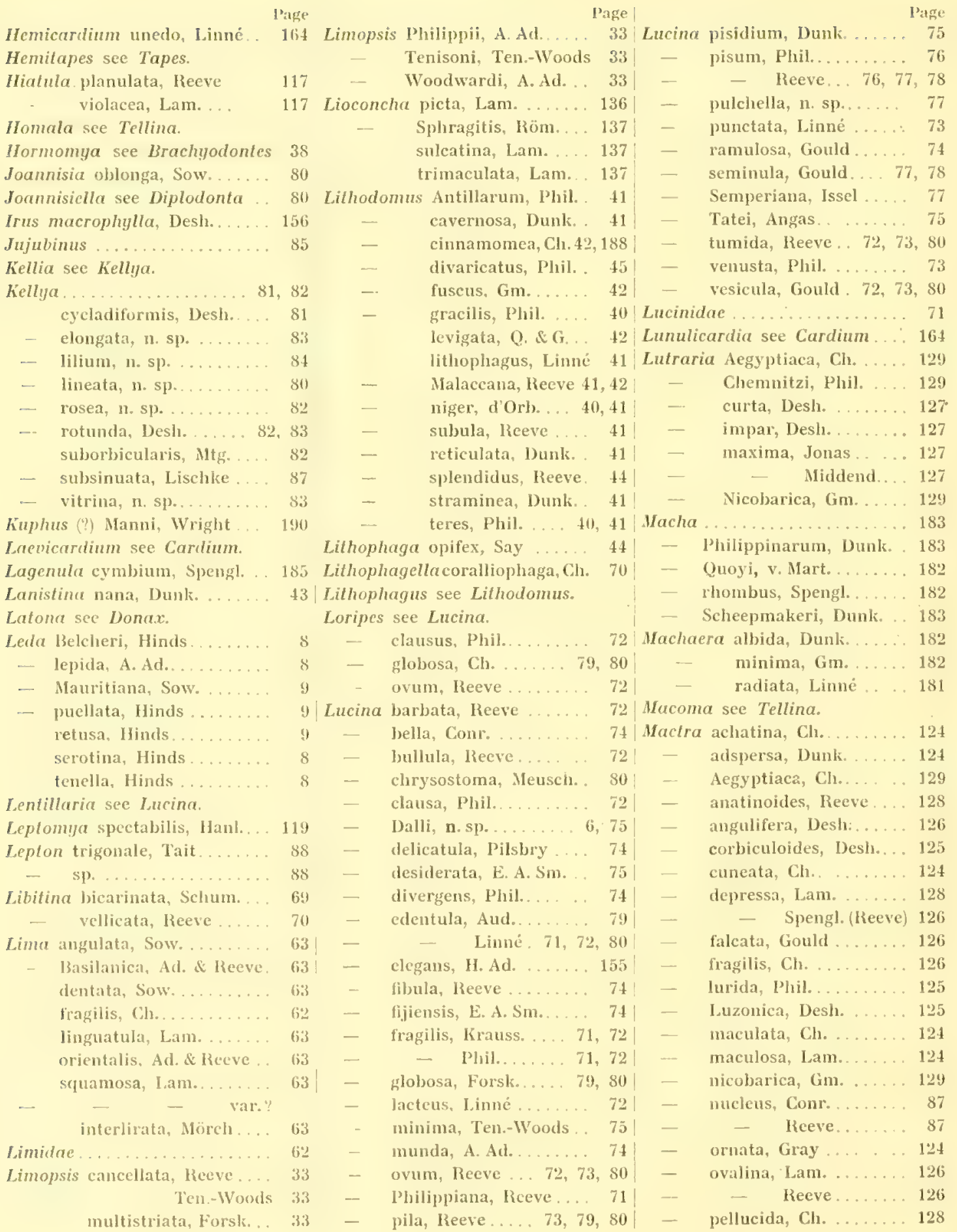


l'age| Page Page

Mactra purpurea, Spengl. ... 125 Modiola divaricata, Phil. ... 45 Myidae. ............. 169

- pusilla, A. Ad. ........ 126

- Reevei, Desh......... 12t

- Reevesi, Gray ....... 127

- reticulata, Spengl. ... 129

- rostralis, Desh. ....... 1

- rugosa Indiae orientalis,

Ch. ........... 12

setosa, Quoy ........ 12

squalida, Lam. ..... . 12

sulcata, Valenc........ 12

Mactridae .............. 12

Mactrinula see Mactra ...... 12

Maera see Tellina .......... 10

Malleus albus, (Ch.) Lam. .... 49

- anatinus, Lam. ......

decurtatus, Iam..... . .

figuratus, Ch. ....... 4 .

- regula, Forsk. .......

- - - var. de-

curtatus, Lam. .....

tigrinus, Reeve....

vulsellatus, Lam.

Mantellum see Lima.

Margaritifera see Pteria.

Martesia fluminalis, Blanf.

Grayana, Leach .... 189

- multistriata, Sow. ... 189

- rivicola, Sow. ...... 189

- striata (L.), Sow. 187, 188

Neretrix see Cytherea... 130, 131

Merope see Standella... 128, 129

Meleagrina see Pteria ........ 48

Irelina Cumingi, Reeve .

- Isogonum, Linné. .

- nucleus, Lam.

Merisca see Tellina.

Mesodesma crassula, Desh.

- glabrata, Lam.

mitis, Desh.

Savignyi, Jouss. ... 12

striata, Ch. . . 122, 123

Mesodesmatidae ........... 122

Metis see Tellina.

Minutissima leguminum, Ch... 182

Modiola angusta, Cless....... 38 arcuatula, Hanl. .... 37 barbata, Linné ... 35, 36 cinnamomea, Lam.... 42 cultellus, Desh. ..... 38

- Cumingiana, Dunk. . . 43 difficilis, Desh.

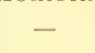

$43 \mid$ Montagua . . . . . . . . . . . . .

44 Monlaguia .................
Myodora trigona, Reeve ..... 191

Murtea see Lucina, . . . . . . 73, 78

Mysia oblonga, Sow. ........ 80

Mytilicardia variegata, Brug... 67

Mytilidae ............. 33,54

Mytilus bilocularis, Linné .... 39

4 - cinnamominus, Ch. ... 42

8 - coralliophagus, Clı... 45

- excisus, Wiegm. .... 40

- fuscus, Gm........ 42

- Hyotis, Linné ....... 65

- lithoplıagus, Ch...... 40

- Nicobaricus, Cl...... 39

opalus, Lam........ 34

- smaragdinus, Clı... . 34

- viridis, Limné ....... 33

Naranio costata, Lam ....... 157

- divaricata, Ch. .... 157

lapicida, Ch.... 157, 188

Nausitora edax, Hedl. ....... 191 Manni, Wright.... 190

Neaera fragilis, A. Ad. ....... 118 Gouldiana, Hinds .... 193

lata, Hinds ......... 118 pulchella, H. Ad. ...... 193 rosea, Hinds. . . . . . . 193

- Singaporensis, Hinds . 192

Novaculina andamanensis,

Preston 184

Siamensis, Morl... 182

Nucula Belcheri, Hinds...... 8

convexa, Sow. ....... 7

Cumingi, Hinds...... 7

Layardi, A. Ad...... 7

Mauritiana, Solv. ..... y

puellata, Hinds...... g 9

retusa, Hinds....... !

serotina, Hinds ....... \&

tenella, Hinds ....... S

Nuculana Belcheri, Hinds .... \& mauritiana, Sow... y nasuta, Sow...... g puellata, Hinds ... g 9 retusa, Hinds ...... g

Nuculidae ............. 7

Omphaloclalhrum see Chione. 146

Ostrea anatina, Gm......... 49

- arborea, $\mathrm{Cl} . \ldots . \ldots .6,60$

- attenuata, Sow. ...... 64

- circumsuta, Gould....64 


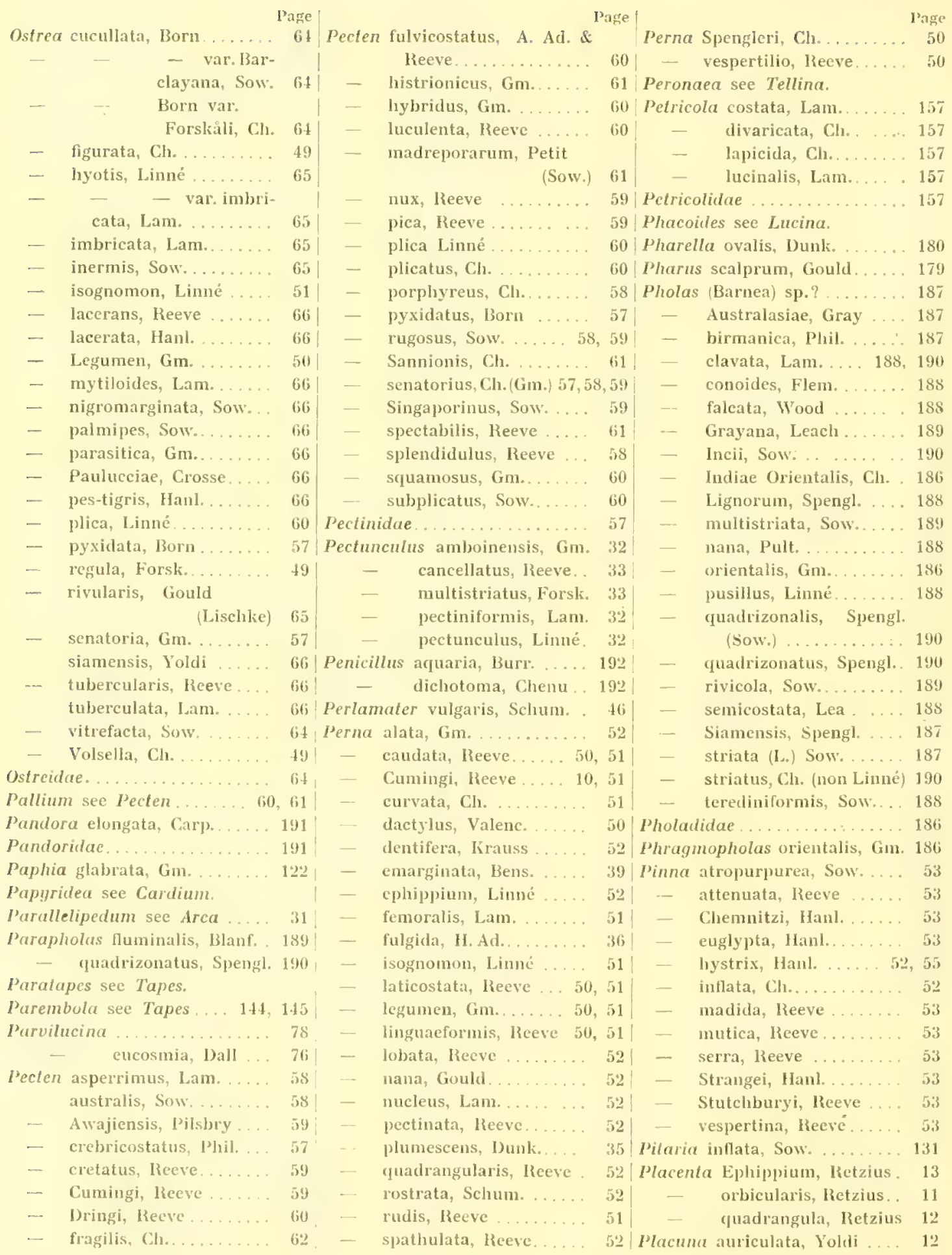




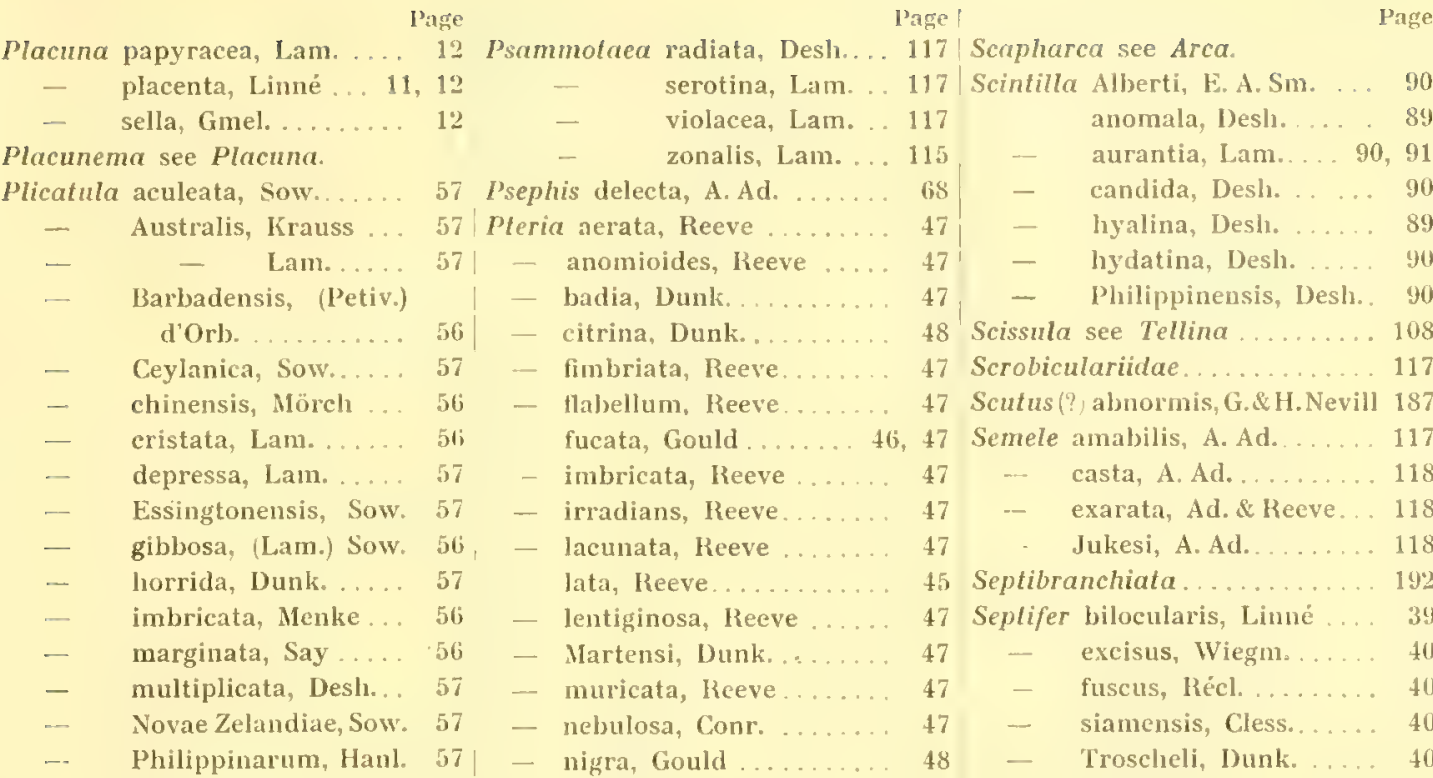

- plicata, Ch. ....... ramosa, Lam. ..... 56

reniformis, Lam. ... 56

spondyloidea,Meusch. 56

Poromya pulchella, Ad. \& Reeve 127

Portlandia see Leda ........ y

Protapes see Tapes.

Protobranchiata .......... 7

Psammobia.............. 10!

- amethystus, Reeve 115

anomala, Desl. 115, 116

- compta, Desh.... 115

- corrugata, Desh. . 114

- maculosa, Lam. ... 114

- marmorea, Desh... 115

- micans, Hanl..... 109

- orbicularis, Desh. 116

- ornata, Deslı. ..... 114

puella, Desh. .... 115

- radiata, Dunk.... 11

- rubicunda, Desh... 114

- rugosa, Lam. .... 113

- scabra, Ch. ...... 114

- $\quad$ simplex, Sow..... 116

- striata, Desh..... 115

Tellinaeformis,

Desli. $11 j$

tenuis, Desh. .. . 115

- zonalis, Lam,..... 115

Psammobiidae............ 113

113

Psammocola rugosa, Lam..... 114

-- occa, Reeve

47, 48 Sersula see Donax ..... 119, 120

- perviridis, Reeve

- placunoides, Reeve

pulchella, Reeve..... 46 - Spengleri, Ch...... 50

4

Siliqua minima, Gm....... 182

serrulata, Dunk...... $45 \quad$ subelliptica, Dunk.... 179

- spectrum, Reeve..... 45 - Winteriana, Dunk.... 182

- tristis, Dunk. ........ 48 Solecurtus abbreviatus, Gould 183

- varia, Dunk......... 47

- vulgaris, Schum. ..... 46 - var.occa,

Reeve ....... 47, 48

- zebra, Reeve

- albus, Quoy \& Gaim. 182

- antiquatus, Pult. ... 184 coarctatus, Gm .. 183, 184 emarginatus, Spengl. 183 oblongus, Dunk. .... 183 Philippinarum, Dunk. 183 Quoyi, Desh....... 182 rhombus, Spengl. ... 182

Pullastra see Tapes......... 143

Pythina Deshayesiana, Hinds. 83 paula, A. Ad. ....... 86

- peculiaris, A.Ad..... 86

- triangularis, A. Ad

Quadrans see Tellina.

Radula see Lima.

Rac̈ta anatinoides, Reeve.... 128 bracheon, Sturany .... 128

- pellicula, Desh. pulchella, Ad. \& Reeve , 127 rostralis, Desh.

Scheepmakeri, Dunk.

183,184

solidus, Sow....... 183

Solen abbreviatus, Phil..... 178 albida, Ad. \& lieeve.... 182

- anatinus, Linmé ... 184, 191

- angustior constrictus etc.,

Ch. ............ 183

- antiquatus, Pult. ...... 183

- brevis, Reeve ........ 178

Rocellaria gigantea, Desh.... 181| - Ceylonensis, L.cach .... 178

Ruditapes see Tapes. $\quad$ - coatctatus, Gm. . . . . 183

Rupellaria macrophylla, Desh. 156 - constrictus, Ch........ 184

Sanguinolaria dichotoma, Anton $114-$ corneus, Lam........ 178

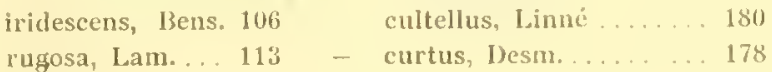

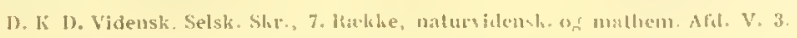




\begin{tabular}{|c|c|c|c|c|c|c|}
\hline & & Page | & & $\begin{array}{l}\text { Page } \\
\end{array}$ & & Page \\
\hline Solen I & Diphos Chinensis, Ch. . & 117 & Spond & lylus virgineus, Reeve... 55 & Tellina & \\
\hline - c c & cmarginatus, Spengl. ... & $183 !$ & — & zonalis, Lam. ..... & - & clathrata, (Quoy) Desh. 107 \\
\hline & ex albido radiatus, Ch. & 103 & Stand & ella Aegyptiaca, Ch. ... & - & coarctata, Phil. ..... 109 \\
\hline$=$ & grandis, Dunk. . . . . . . . & 178 & | & Nicobarica, Gn. & - & compacta, E. A. Sm. .. 105 \\
\hline & intermedius, lioch. . & 178 & - & pellucida, Ch.. . & - & compta, Gould ...... 107 \\
\hline & linearis, Spengl. & 178 & Tapes & aspera, Reeve ..... & - & constricta, Brug. ...... 113 \\
\hline & is, Gm. & 182 & - & decussatus, Linné.. & - & corbis, Sow. . . . . . . 94 \\
\hline$x^{2}$ & tus. Wood. & 116 & - & denticulata, Sow. ... & - & corbuloides, Hanl... . \\
\hline . & Is, Spengl. & 182 & - & ducalis, Röm...... & - & crystallina, Wood.. \\
\hline & radi: & 181 & - & flammulata, Lam. . . & - & cygnus, Hanl......... 108 \\
\hline & k..... & 178 & - & grata, Desh. . . . . . . & - & declivis, Sow. . . . 97, 98 \\
\hline- & ous, Spengl. & 182 & - & hiautinus, Lam..... . & - & depauperata, v. Mart.. 109 \\
\hline- & scalprum, Gould. & 179 & -- & Japonica, Desh. ........ 143 & - & Deshayesi, P. Carpenter \\
\hline - & King . & 179 & - & Indica, Hanl. . . . . . 143 & - & - Hanl. . . . . 91 \\
\hline & striatus, Gm. & 102 & - & lentiginosa, Reeve..... 141 & - & Diana, Hanl. . . . . . 110 \\
\hline & latus var., Ch. . & 182 & - & Malabaricus, Ch. . 141, 142 & - & dispar, Conr. .... ... 107 \\
\hline & ood (Sow.). & 178 & - & - $\quad-\quad$ var. si- & - & donaciformis, Desh. ... 112. \\
\hline$=$ & ides, Lam. . . & 179 & & nuosus, I.am. ....... 142 & - & elegantissima, E. A.Sm. 94 \\
\hline Solenid & & 178 & - & obscuratus, Deslı. ..... 145 & & , Sow. 100,101,102 \\
\hline Solen & curtus Philippinarum, & & - & papilionaceus, Lam.... 140 & & pium, Spengl. 109, 110 \\
\hline & & 183 & - & Philippinarum, Ad. \& & & erythraeensis, H.Ad. . $10 \mathrm{~S}$ \\
\hline - & Siamensis, Morl. & 182 & & Reeve 143 & - & 11sis, Desh... 112 \\
\hline Solenot & tellina see Soletellina. & 117 & - & polita, Sow....... 140, 141 & - & fabrefacta, Pilsbry .... 93 \\
\hline Soletell & lina Chinensis, Ch. & 117 & - & puniceus, Desh....... 144 & & fallax, V. Bertin ...... 111 \\
\hline & lata, Wood. & 116 & - & quadriradiata, Desh. ... 14j & & fausta, Pult. ........ 95 \\
\hline & Reeve & 117 & - & tus, Ch. ........ 144 & & galataea autor.(nonLam.) il 10 \\
\hline & reversa, Heeve. & $116^{1}$ & - & rhomboides, Penu. . . . . 143 & & gargadia, Linné ..... 100 \\
\hline & ta. Heeve & 117 & - & a, Phil. . . . . . 141 & & Sa, Römer..... 102 \\
\hline & cea, Lam. & 117 & - & $a m . . . .$. & & eri, Phil. ... 109, 110 \\
\hline Sphenia & ia elliptica, A. Ad. & 177 & - & data, lieeve..... 140 & & laculum, Hanl. 110, 111 \\
\hline & inaequalis, L. A.Sm. & 177 & - & semidecussata, Desh. ... 144 & - & habrotima, Melv. ..... 94 \\
\hline & perversa, Blanf. 176,1 & 177 & - & s, Phil.... & - & poidea, Jonas.... \\
\hline- & quadrangularis, 1). sp. & 176. & - & similis, Reeve. . . . . . . 145 & & Hungerfordi, Sow..... 92 \\
\hline Spondyl & lidae & 54 & - & simnosus, Lam. . . . . . 142 & - & inaequalis, Hanl. . . . . 100 \\
\hline Spond!y & Ilus aurantius, Lan. . & 55 & - & us, (Ch.) Gm.... & & nata, Hant. ..... 94 \\
\hline & camurus, Reeve & 55 & -- & tristis, Lam. . . . . . . . 143 & & inflata, Ch. ......... 94 \\
\hline & castus, Reeve.. & 55 & - & undulatus, Born..... 141 & - & inquinata, Deslı. ..... 113 \\
\hline & coccinens, Lam. & & - & variegatus, Sow. (Hanl.) 14t & & iata, Say ...... 109 \\
\hline & (Reeve) 54, & 55 & - & violascens, Desh....... 144 & - & ens, Bens. ..... 106 \\
\hline & ducalis, Clı. . & 55 & - & virgineus, Linné ....... & - & la, v. Mart. . . . . 106 \\
\hline- & fragilis, Sow. & 55 & Tellim & tya see Montacuta. & & Isseli, H. Ad. . . . . . . 46 \\
\hline & m, Reeve & 55 & Tellina & a aenigmatica, Ch..... & & a, H. Ad. ........ 108 \\
\hline & rdi, lieeve & 56 & - & anomala, Born ...... 113 & & lacunosa, Ch..... 109, 110 \\
\hline & maculatus, Ch. & 55 & - & arafurensis, L. A. Sm. . 110 & & languida, E. A.Sm...95, 98 \\
\hline & mus, Reeve & 5.5 & - & balaustina, Linnc .... 96 & - & lauta, Gould . . . . . . 107 \\
\hline & Nicobaricus, Ch.... & 55 & - & Berghi, n. sp....... 104 & & lilium, Наn!. \\
\hline & atus, Reeve 54 , & 55 & - & bifaria, Baird....... 108 & & lux, Hanl. ...... \\
\hline- & plurispinosus, Reeve & 5.5 & - & candida, Lam. . . 110,111 & & Malaccana, Sow. . \\
\hline & Sinensis, Sow. & 54 & - & capsoides, Lam. ... 93, 94 | & & Martensi, n. sp.... \\
\hline & uliferus, I am. & 56 & - & carinata. Spengl. . . . . 100 & & micans, Hanl...... \\
\hline & , Reeve... & 55 & - & camea, Phil......... & - & minor, V. Bertin ..... 100 \\
\hline & spinosus, Sow. & 55 & & carnicolor, Hanl. . . . . 9t & - & miracyllium, Melv.... 104 \\
\hline - & variegatus, Ch. & 55 & - & caseus, Sow. ....... 107 & & Moluccensis, v. Mart. . 112 \\
\hline
\end{tabular}




\begin{tabular}{|c|c|c|c|c|c|c|}
\hline & l'age & & Ixt? & & & l'inge \\
\hline ellii & nasuta, Conr: & Theora fragilis, A. Ad.. & 118 & Venus & globosa, Forsk. & $7 !$ \\
\hline & negrosiensis, V. Bertin . 93 & - lata, Hinds... & 118 & & tina, Lam. & \\
\hline - & nux, Hanl. 96. 98 & Thyasira see Lucina. & & & japonica, Gm. & \\
\hline & oblonga, Gm..... 100, 101 & Tichogonia bilocularis, Linné & 39 & & ta, Solv. & \\
\hline- & obtusalis, Desh. ...... 105 & - $\quad$ excisa, VViegm... & 40 & & ca, Lam. & \\
\hline - & ostracea, Hanl......... 94 & - $\quad$ siamensis, Cless. & 40 & & ina. Phil. & \\
\hline & ovalis, Sow. . . . . . . 102 & Timoclea see Chione. & & & I. Desh. & \\
\hline & papyracea, Spengl. ... 110 & Tivela bicolor, Gray ... & 134 & & clki, Gray & \\
\hline & perna, Ch. 91 & Trachycardium see Cardium. & & & is, Schum. & \\
\hline - & perplexa, Hanl... & Trapezium angulatum, Lam... & 169 & 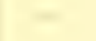 & ida, Ch. & \\
\hline - & - Römer & - dactylus, Brug. ... & 71 & - & ta, E. A.Sm. .. & \\
\hline- & pinguis, Hanl. ....... 95 & gracilis, Sluttlew. & 71 & - & ata, radiata, Ch. & 14 \\
\hline- & psammotella, Lam. . 101 & rostratum, Lam. . & $i 1$ & & , Ch. . & \\
\hline- & pudica, Hanl. ..... 97, 98 & - vellicatum, Reeve & 70 & & Malabarica, Ch. & 14 \\
\hline · & pulcherrima, Sow. .... 92 & Tridacna crocea, Lam. . & 167 & & ca, Linné & 11 \\
\hline & pura, H. Ad. ........ 108 & gigas, Linné & $16 i$ & & trix, Linné & 13 \\
\hline - & reticulata, Sow. . . . . 107 & - var. squa- & & & 1, Sow. . & $1, i$ \\
\hline- & rhomboides, (. \& G. ... 107 & mosa, Lam. & 167 & & cea, Lanı. & 14 \\
\hline & robusta, Hanl. .... . . 98 & rudis, Reeve.. & 167 & - & , Linné & 13 \\
\hline - & rostrata, Linné .... 91, 92 & squamosa, Lam. & 16 liti & & narum, A. Ad. \& & \\
\hline- & rugosa, Born....... . 92 & Tridacnidae ....... & Itir & & $\cdots$ & $14:$ \\
\hline & Savignyi, Ad. ...... & Trigonella see Mactra. & & & né & 15 \\
\hline & scabra, Clı . 111 & Trisidos, (Bolten) . & 31 & 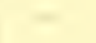 & né & $7:$ \\
\hline- & semen, Hanl. . . 102, 104 & see Arca. & & & $\mathrm{m}$ & $11:$ \\
\hline- & semilaevis, v. Mart. . . 101 & Trisis, $101 \mathrm{k}$ & 31 & - & iata, Desh. . & 14 \\
\hline- & semitorta, Sow. . 103, 104 & Vencridue & 130 & & Ch. .... & 14 \\
\hline & sericina, Jonas ....... 110 & Vonerupis at & 156 & - & E.A.Sm. & $14 t$ \\
\hline- & Siamensis, v. Mart. & $-d$ & 15 & & , Li & 1.i \\
\hline- & silicula, Desh. . . . . 107 & exotica, Hanl. .. & 157 & - & ra, Hanl. & $1+1$ \\
\hline - & sinuata, Spengl. ...... 110 & ta, Sow... & 156 & - & iil. . . . . & 141 \\
\hline - & Smithi. 11. s]. & Irus, Linnc: & 15 & - & 1. & 14: \\
\hline - & Spengleri, Mart. (Ch.).. & macrophylla, Desh. & 156 & & Ia, Issel & 14 \\
\hline- & Strangei, Desh. ...... 94 & esh. & 157 & - & anl. & 1 t: \\
\hline & striatula, Lam. ...... & planicosta, Deslı. & 157 & & né & 131 \\
\hline - & subrosea, Röm........ 108 & - semipurpurea, Dunk. & 157 & & esh. & $1 ; 1$ \\
\hline - & tenuilirata, Sow.... . 104 & Ventricola see Chione.. & 151 & - & gata, Phil. & 1111 \\
\hline & tenuis ovalis, Ch. .. . . 100 & Venus_ca & 143 & - & Lam. & $11:$ \\
\hline- & tenuisculpta, n. sp.... 112 & - ca & 150 & & Linné . & 11. \\
\hline- & texturata, Sow. ...... 107 & - cancellata, Cli var. . & 150 & & psa. Hanl. & 117 \\
\hline & tridentata, Anton. & Cochinensis, Sow. . & 148 & - & Gould & 1.11 \\
\hline -- & truncata, Hanl. ... & Lam. & 150 & & & 143 \\
\hline & - Jonas...... 111 & lifera, Ad. \& Reeve & 147 & & I3orn & 111 \\
\hline - & unifasciata, Sow. . . . . 106 & crebrisulca, Sow. ..... & 151 & & a, Hanl. & $1+1$ \\
\hline & lis, Hanl. . . . . . . . & ta, Linné ... & 113 & & , Gin.. & $11 ;$ \\
\hline- & virgo, Hanl. . . . . . . . & ; Ch. & 139 & & ns, Forsk. & $11: 3$ \\
\hline & ella, Ch. ..... 91, 92 & icata, Ch. & 157 & & a, Linné & $14: 3$ \\
\hline & la see Tellina. & (Crista) divaricata, Ch. & 139 & - & a, Lam... & $14:$ \\
\hline & ae $\quad \ldots \ldots \ldots$ & ens, Gm. & 157 & & a, Lam. & 1311 \\
\hline & es see Tellina. & - & 151 & & & (i1 \\
\hline & lae $\quad \ldots$. & tla, Linné & 71 & Yoldia & a, Hinds & 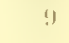 \\
\hline & $19(1)$ & ulata, Lam. . & 143 & & , Hinds & is \\
\hline atit & - 10 & gallus, Spengl... & 142 & & nds. & \\
\hline
\end{tabular}


. 


\section{,}




\section{Plate I.}

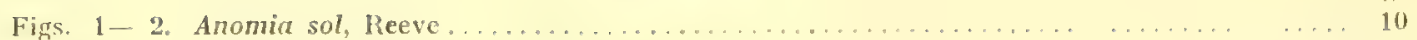

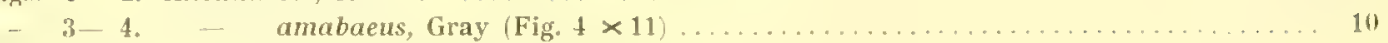

5-10. Arca (Barbatia) complanala, Ch. . . . . . . . . . . . . . . . . . . . . .

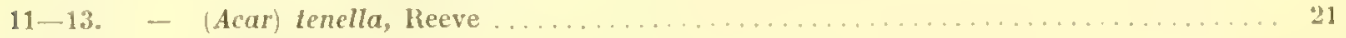

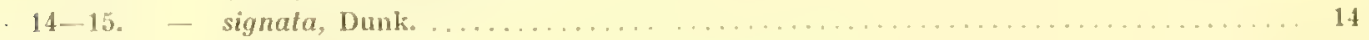

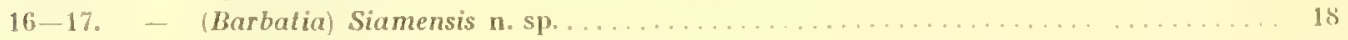

18-19. Nuculana Belcheri, Hinds. . . . . . . . . . . . . . . . . . . . . . . 

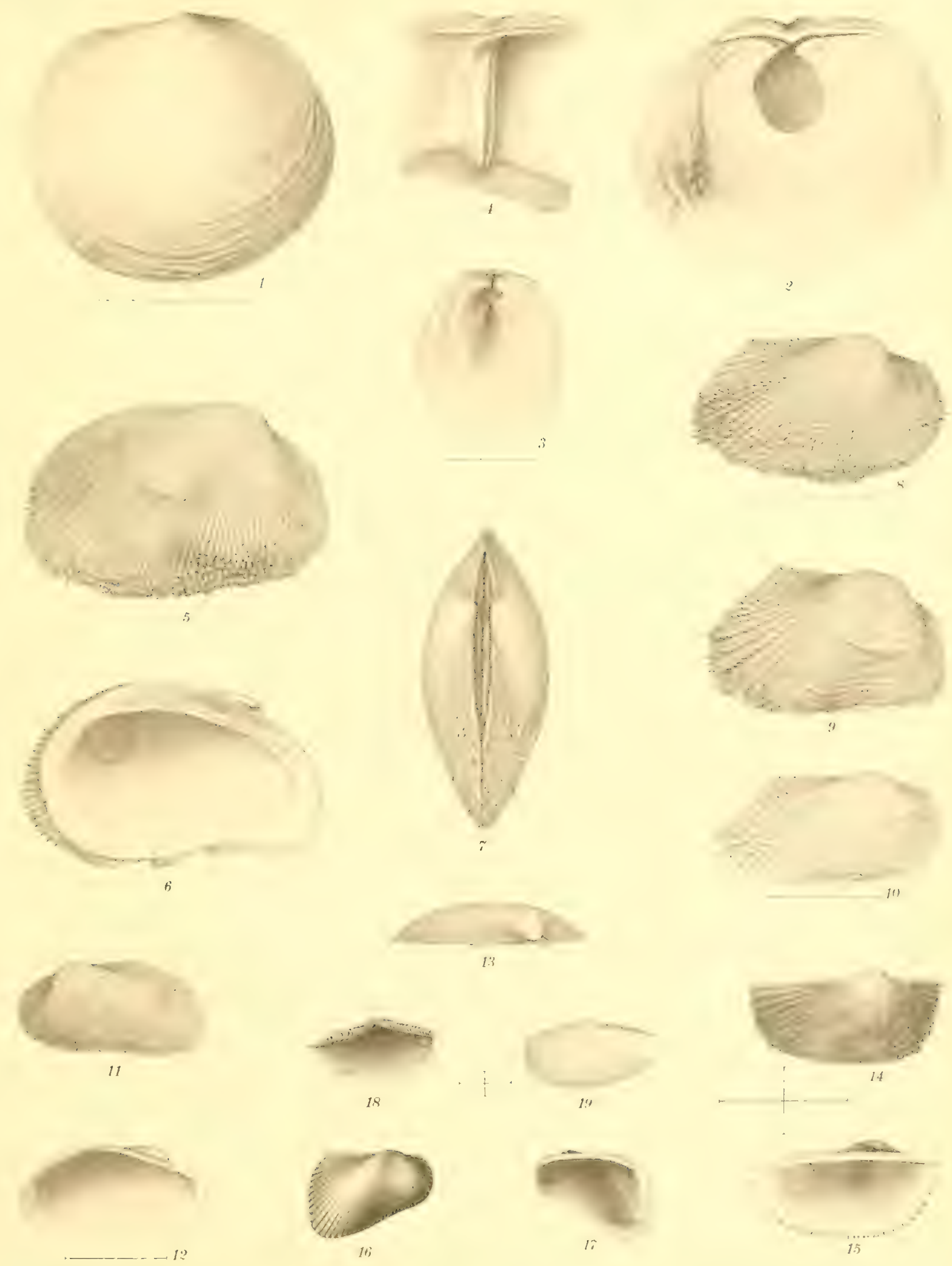


\section{.}





\section{Plate II.}

Figs. 1 2. Area (Anadara) Mortenseni in sp. ..............

3. (Scapharca) dichotoma, Desh, var, gratiosa m.

- 5-12. - (Scapharca) indica (Gm.). From specimens in Spevgler's collection ........ 30

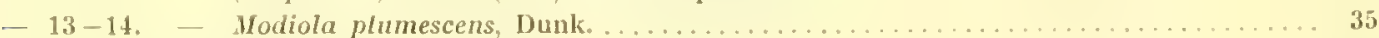

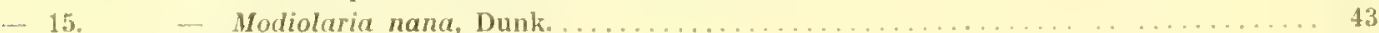

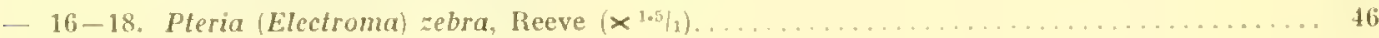

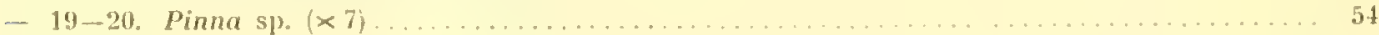



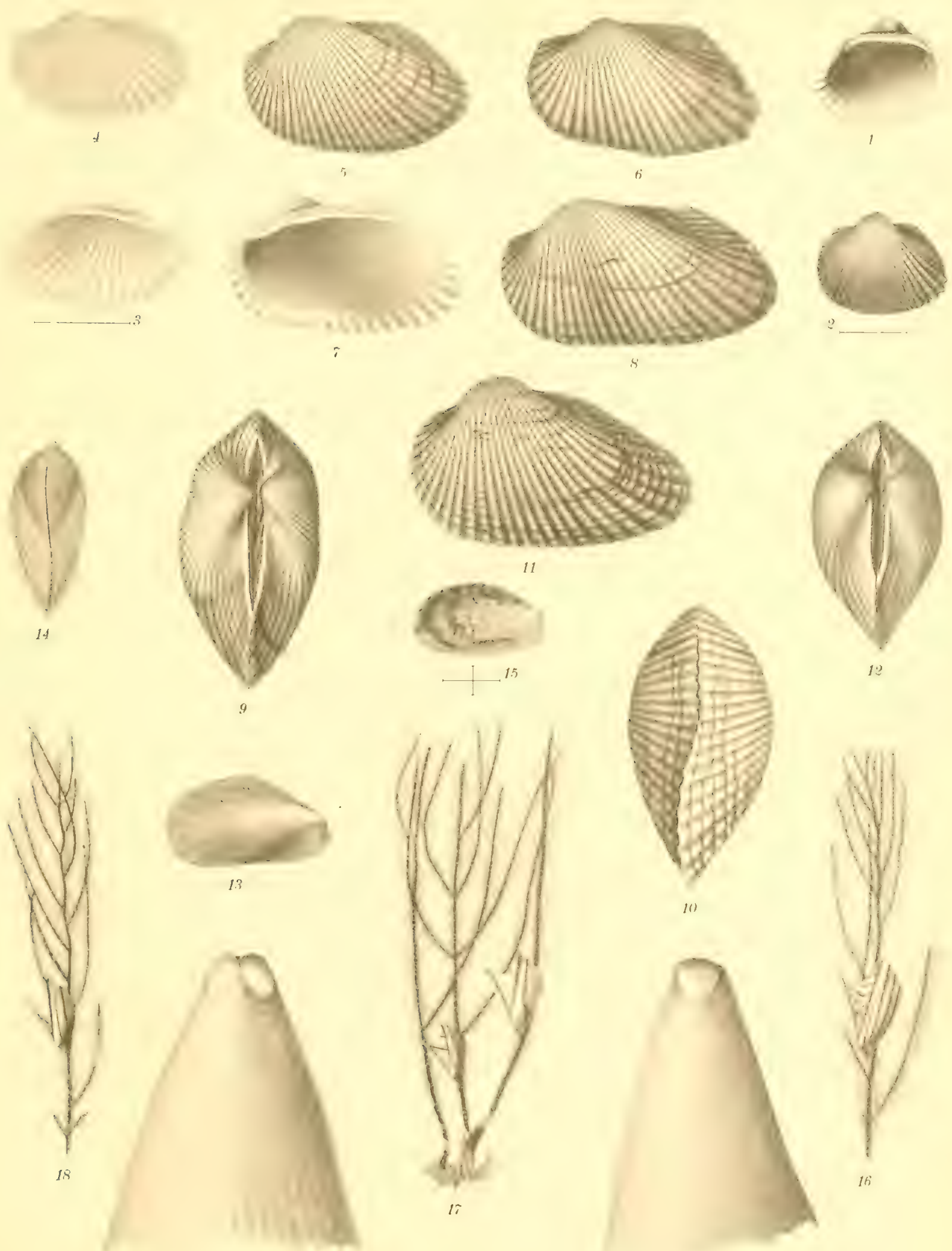
. 



\section{Plate III.}

I'alge

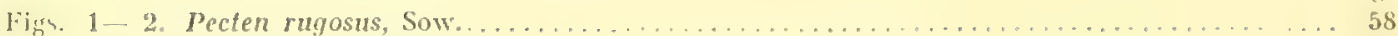

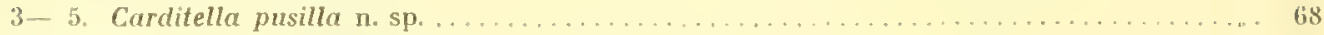

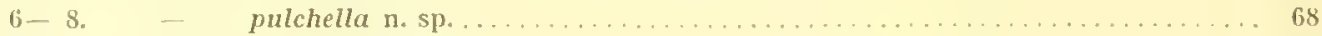

1) -12. Lucina (Phacoides) Dalli n. sp. . . . . . . . . . . . . . . . . . . . . . . . . . . 75

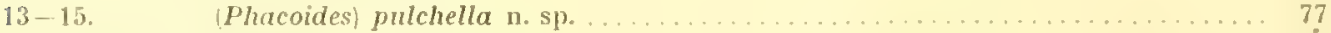

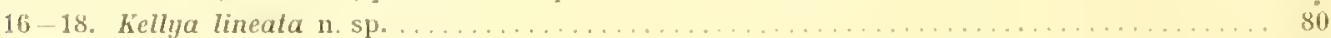

1!) 20\%. rosea $11.81 \% . \quad 82$

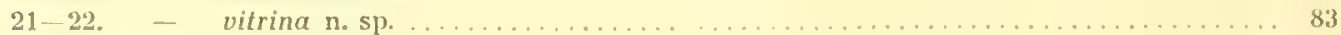

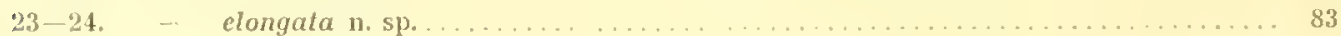

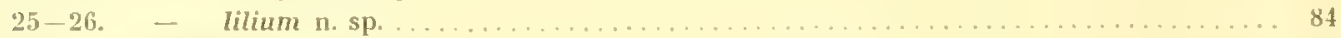

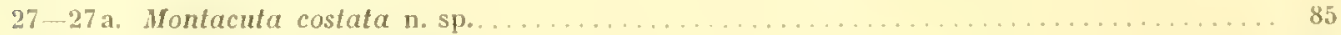

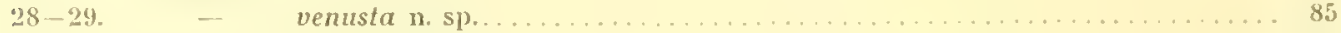

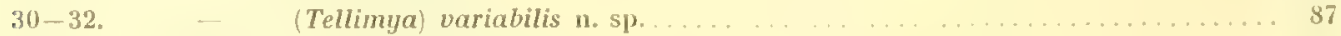

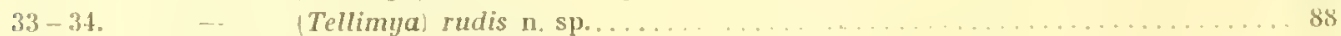

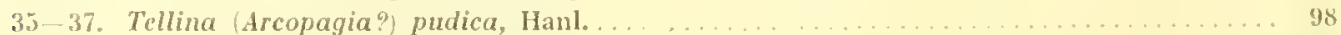

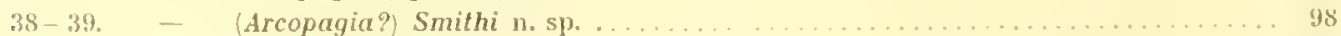

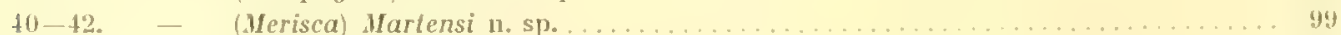

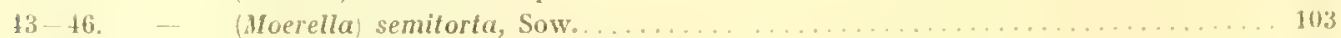

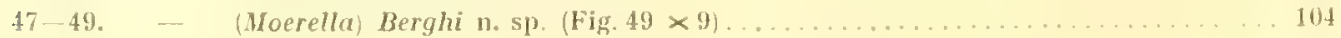

50-52. - (Macoma) papyracea, Spengl. From SPringlek's type-specimens ............ I10 

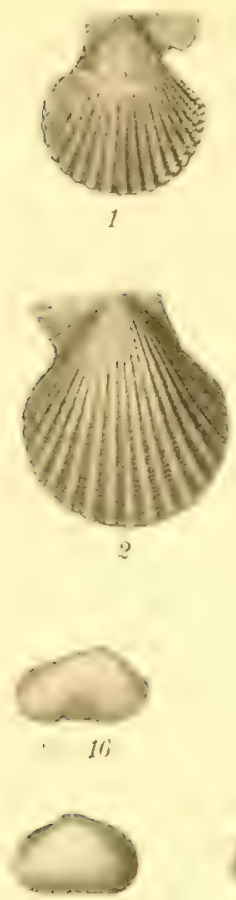

$2: 3$

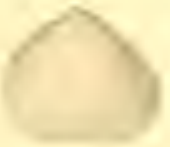

- F 30

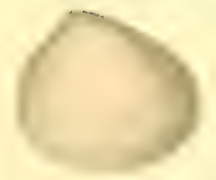

38
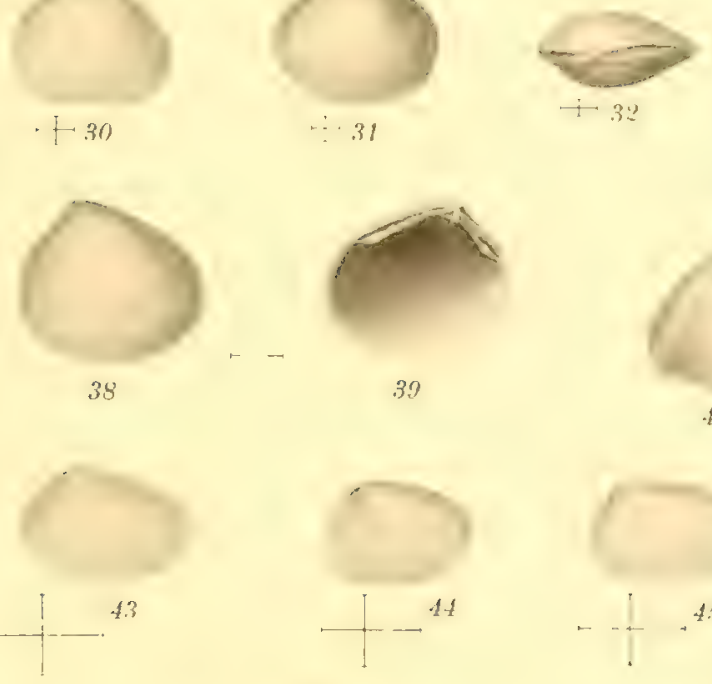

39

15

it $3:$
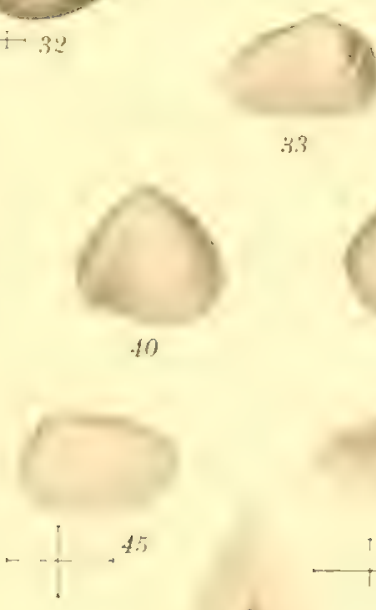

33
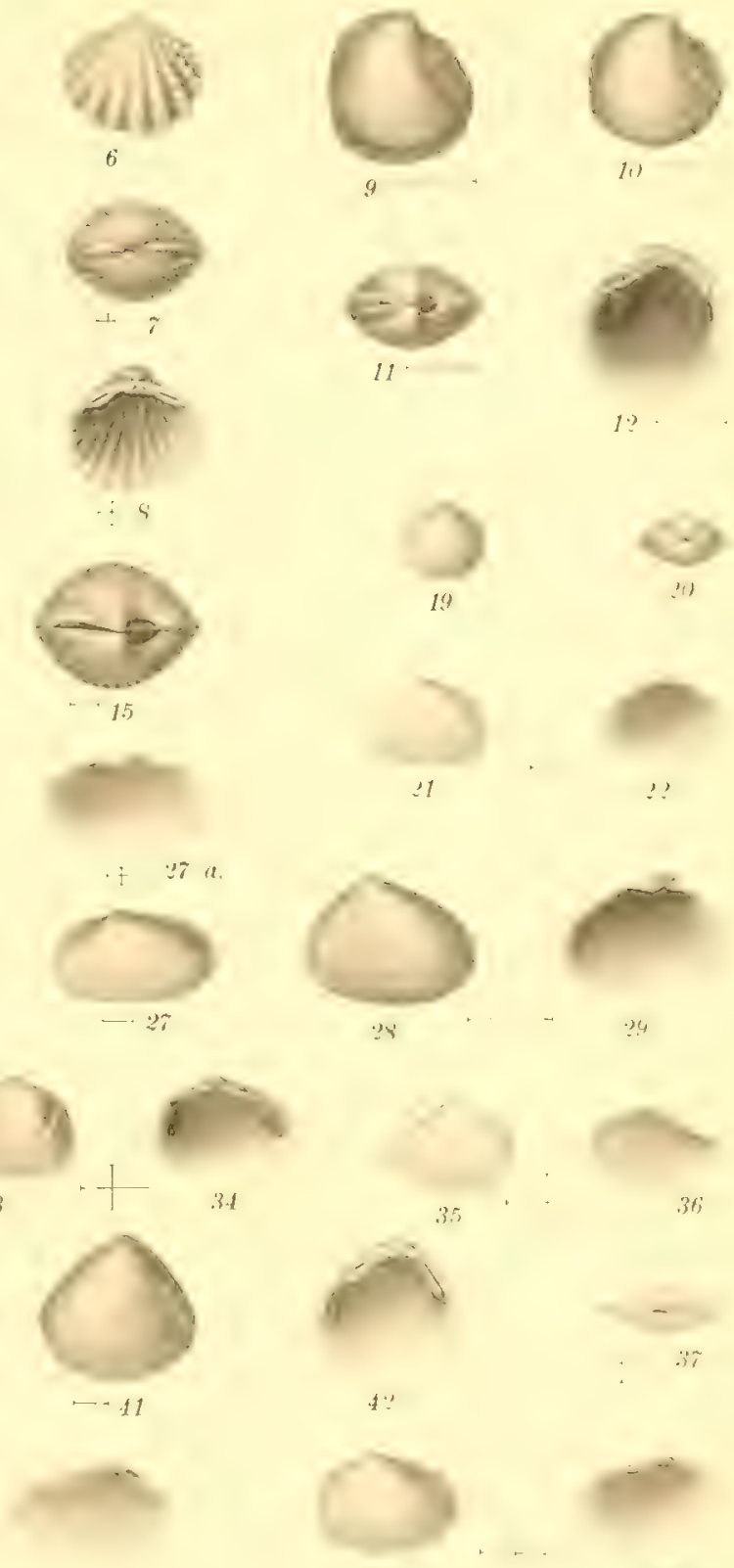
$-\{6$
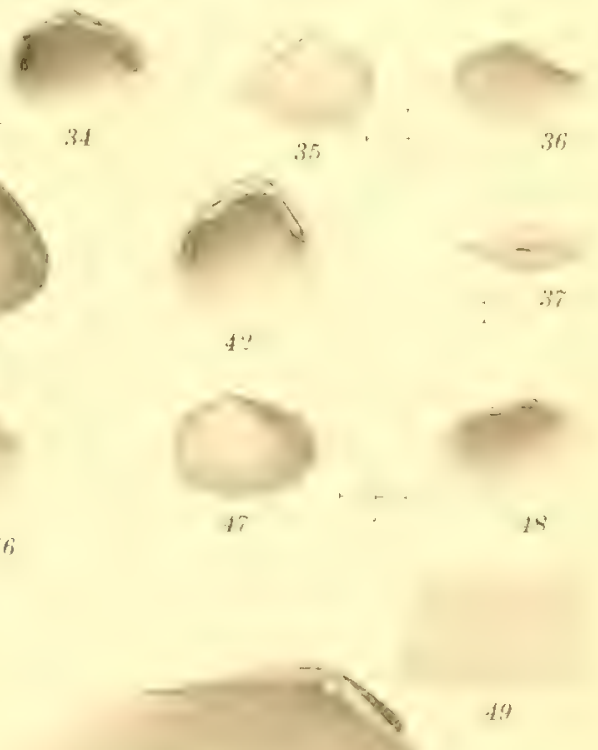
. 



\section{Plate IV.}

Iigs. 1-2. Tellina (Macoma) lilium, Hanl.

3- 5. - (Macoma) tenuisculpta n. sp.

(i) - 8. Pammobia simplex, Sow......

- 9-11. Theora lata, Hinds

12-13. Donax (Serrula) incarnatus. Chemn.

14-16. Ervilia bisculpta, Gould

17-19. Mactra (Trigonella) purpurea, Speng). From Spengler's type-specimens = M. cuneata, chemn.

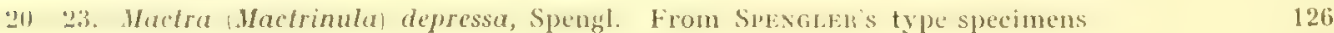

24. Räla palchella, Ad. \& Reeve . . 127

25-27. Cytherę (Caryatisł minuta, Kuch . . 132

28-31. Circe lirata, Römer. . . . . 135

32-33. Melvilli n. sp. .... . . . 135 

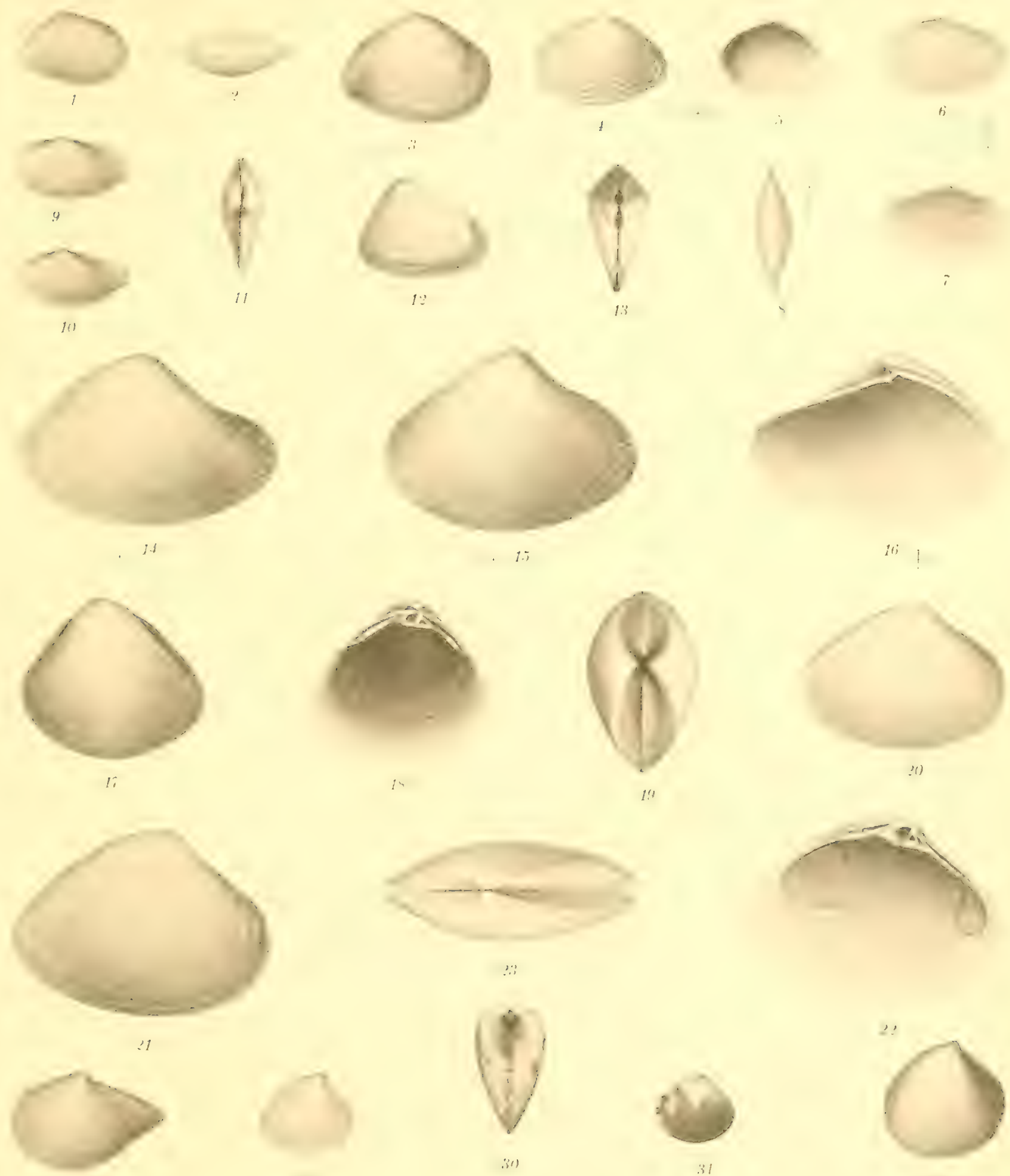

iv

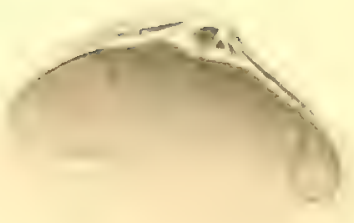

5
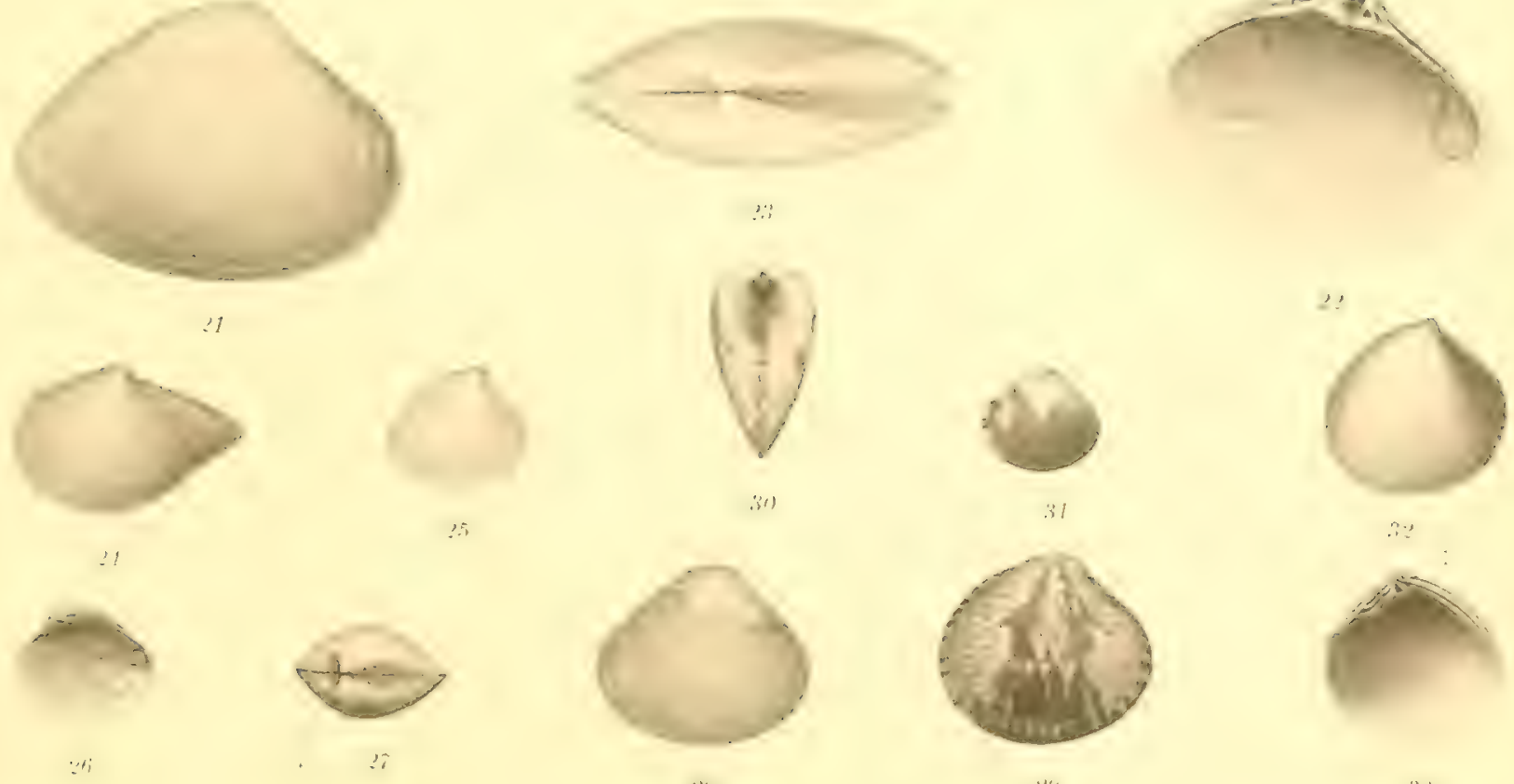

$\hat{\imath}$

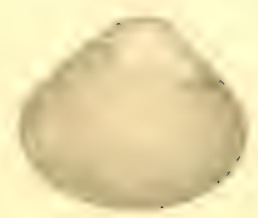

$\therefore 4$

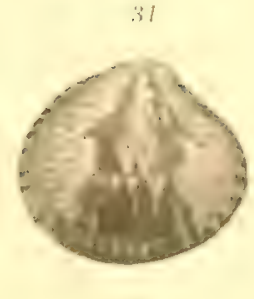

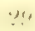

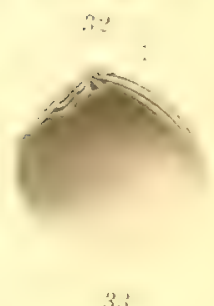






\section{Plate V.}

Chione (Omphatoclathrum) marica L. (Sow.)

- 5. - (Omphaloclathrum) subnodulosa, Hanl. . 147

- 6-7. (Timoclea) Siamensis n. sp.

- 8-10. - (Timoclea) lionata, E. A. Smith... . . . . . 14!

11-13. Dosinia dilecta, A. Adams.

- 14-15. Cyclina elegans, H. Adams. . . . . . .

- 16-19. Cardium (Laevicardium) lobulatum, Deslı. 161

20. Hemicardium (Fragum) fragum L, var. carinata m.

- 21 -22. - (Fragum) carditaeforme, heeve $\quad 115.5$

- 23-24. Corbula lineata n. sp................ 171

- 25-26. arcaeformis n. sp... . 172

- 27-30. - monilis, Hinds .................. 17

31-34. - solidula, Hinds ..... 17 :

- 35-37. - (9) mirabilis n. sp.

- 38-41. Sphenia quadrangularis n. sp................. .

- 42-44. Corbula eburnea, Hinds (= solidula, Hinds $). . . \quad 171$ 
Dan. Exp. to Siam. Znol. Res. IV (H. Lynge).

K. D. Vidensk. Selsk. Skr., 7 R., n.-m. Afd. V, 3. Tab. V.
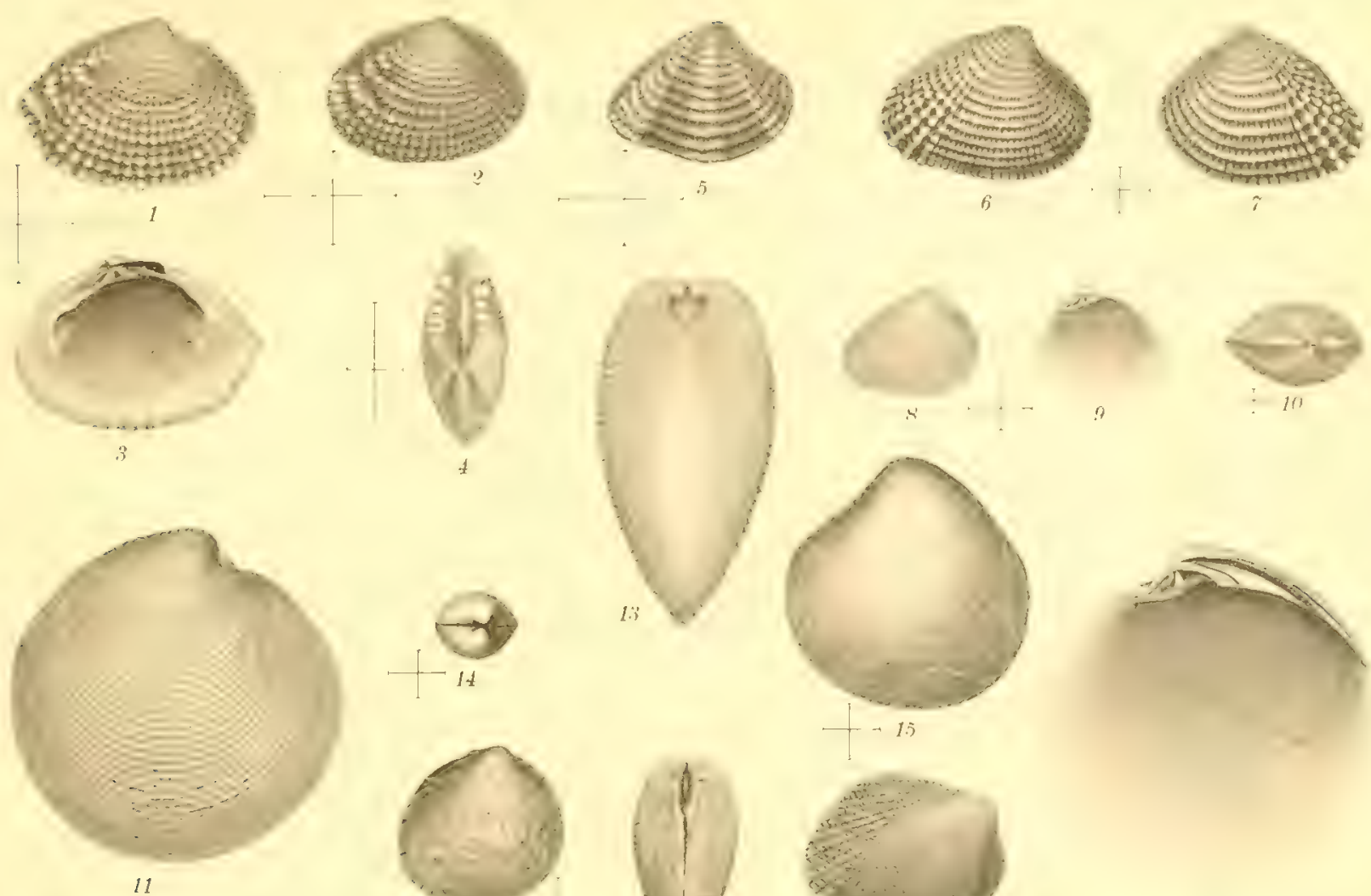

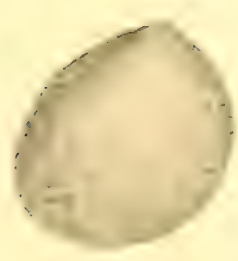

16

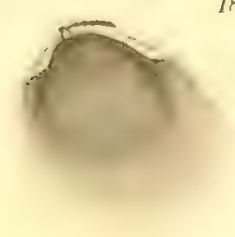

17

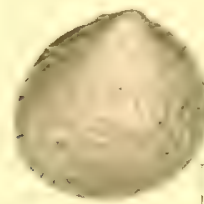

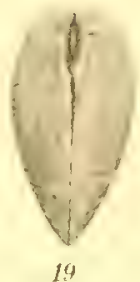

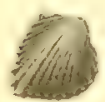

$? 0$

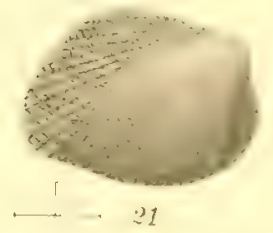

$1 ?$

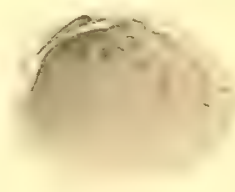

$+x$
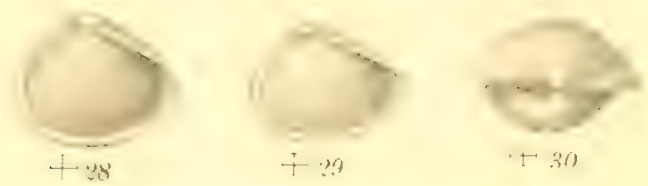

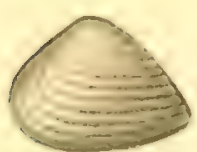

31

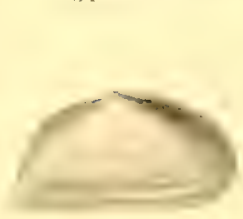

39
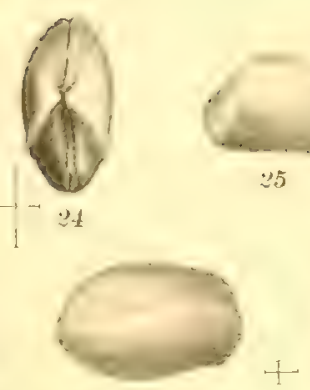

$3 * 3$

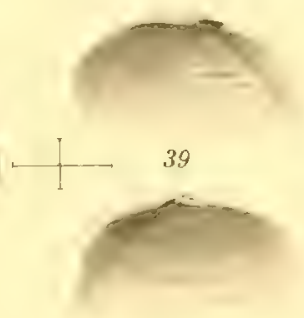

40

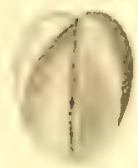

3.3

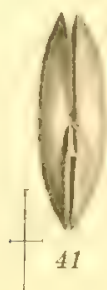

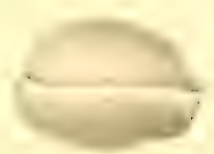

34

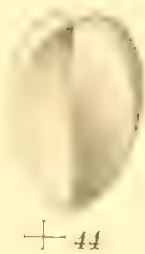

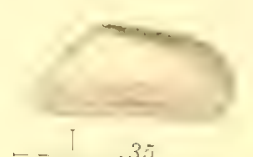

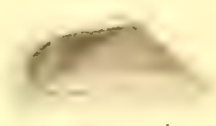

$-\begin{array}{rr}1 & -35\end{array}$
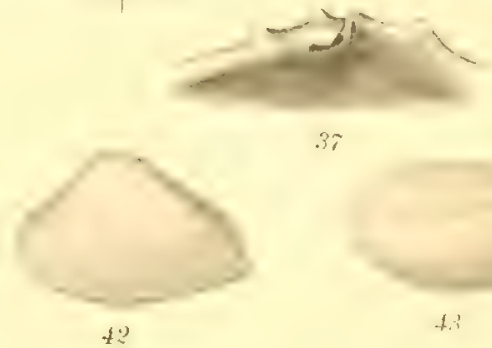

.37 


\section{.}




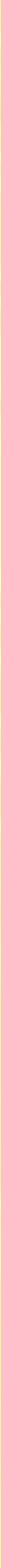


. 


\section{Zoologiske og anatomiske Skrifter

\author{
udgivne af Det Kgl. Danske Videnskaberries Selskab
}

(udenfor Skrifternes 6te Række, se Omslagets S. 2-3):

Bergh, R. Bidrag tll en Monographi af Marseniaderne, m. 5 Tavler. $53 \ldots \ldots \ldots$

- Anatomiske Bidrag til Kundskab om Eolidierne, m. 9 Tavler. $64 \ldots \ldots \ldots \ldots$

4.

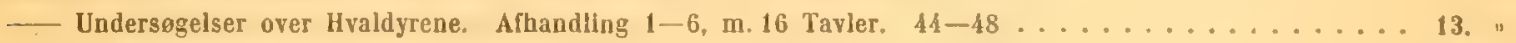

0 m Gangesdelphinen, m. 3 Tavler. $51 \ldots \ldots \ldots \ldots$

Eschricht d Reinhardh $0 \mathrm{~m}$ Nordhvalen, m. 6 Tavler, $61 \ldots \ldots \ldots \ldots$

— N - Navler til 0plysning om Hvaldyrenes Bygning m. Forklaring. $69 \ldots \ldots$. . . . . . . . . . 65.

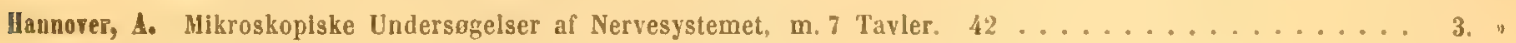

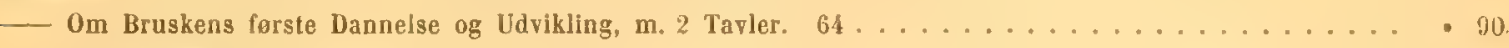

- Jagttagelser over indkapslede Indvoldsorme hos Froen, m. 2 Tavler. $65 \ldots \ldots \ldots$

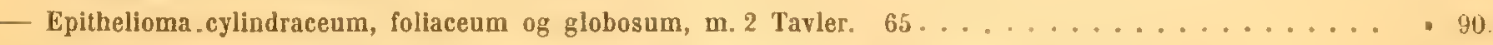

- $0 \mathrm{~m}$ Bygningen $0 \mathrm{~g}$ Udviklingen af Skjæl $0 \mathrm{~g}$ Pigge hos Bruskfisk, m. 4 Tavler. 67............ 2.

— Diets Nethinde, m. 6 Tavler. Explic. des planches en fran€. $75 \ldots \ldots \ldots$

_- Primordialbrusken $0 \mathrm{~g}$ dens lorbening 1 det menneskelige Kranium for Fodselen, m. 2 Tavler. Explic.

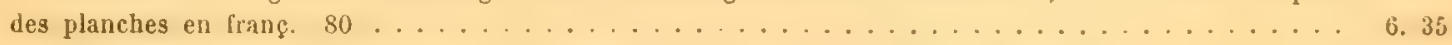

Krabbe, H. Helminthologiske Undersogelser i Danmark og paa Island, m. 7 Tavler. 65........... 2.75

— Bidrag til Kundskab om Fuglenes Bændelorme, m. 10 Tavler. Résumé en fran€. 69........... 4. S0

Kreyer, II. Slægten Hippolytes' nordiske Arter, m.6 Tavler. $42 \ldots \ldots \ldots 35$

Lütken, C. F. Additamenta ad historiam 0phiuridarum. I-III, m. 7 Tavler. Résumé en fran€. 58-69 .. 6. 85

_- Bidrag til Kundskab om Arterne af Slægten Cyamus Latr. eller Hvallusene, m. 4 Tavler. Rẻsumé en frane 73.2 .1 2 Velhas-Flodens Fiske, et Bidrag til Brasiliens Ichthyologi, m. 5 Tavler. Synopsis Latina. 75 . . . . . 6. 75

— Til Kundskab om to arktiske Slægter af Dybhavs-Tudsefiske: Himantolophus og Ceratias, m. 2 Tavler.

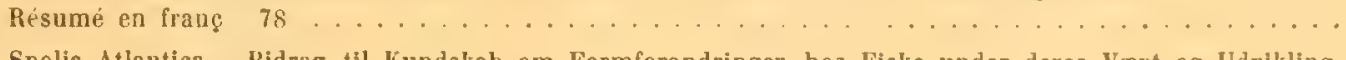

- Spolia Atlantica. Bidrag til Kundskab om Formforandringer hos Fiske under deres Væxt og Udvikling,

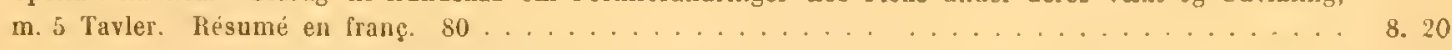

Meloerh Fr. Bidrag til de danske Myrers Naturhistorie, m. 3 Tavler. $60 \ldots \ldots 25$

Prosch, V. Nogle nye Cephalopoder, m. 1 Tavle. $47 \ldots \ldots \ldots$

Reinhardt, J, Beskrivelse af nogle nye Slangearter, m. 3 Tavler. $43 \ldots \ldots \ldots$

- Mephitis Westermannl, et nyt Stinkdyr fra Brasilien, m.1 Tavle. $57 \ldots \ldots$. . . . . . . . . . .

- Bidrag til Kundskab om Kjæmpedovendyret Lestodon armatus, m. 3 Tavler. 75 .......... 2. 20

— Kæmpedovendyr-Slægten Coelodon, m. 5 Tavler, Résumé en franç. $78 \ldots \ldots$. . . . . . . . . .

- Beskrivelse af Hovedskallen af et Kampedovendyr, Grypotherium darwinii, fra La Plata-Landenes plejstocene Dannelser, m. Tavler. Résumé en franc. $79 \ldots \ldots \ldots \ldots$

Reinhardt \& Prosch. $0 \mathrm{~m}$ Scidaephorus Mülleri, m. 5 Tavler. 46..................... 25

Schjodte, J. C. Corotoca og Spirachtha, m. 2 Tavler. $54 \ldots \ldots \ldots . \ldots . \ldots$

Steenstrup, Jap. Rhizochilus antipathum, m. 1 Tavle $53 \ldots \ldots \ldots \ldots$ Hectocolyldannelsen hos Octopodsizgterne Argonauta og Tremoctopus, m. 2 Tavler. 56 ........ 1.35

_ Hemisepius, en ny Slægt af Sepia-Blæksprutternes Familie, med Bemarkinger om Sepia-Formerne i Almiadelighed, m. 2 Tavler. hísunc en franc $7 j \ldots \ldots \ldots \ldots \ldots$ Spolia atlantica. Kolossale Blaksprutter fra det nordlige Atlanterhav, m. 4 Tavler. 98 . . . . . 2.75

Steenstrup Lütkel. Bidrag til Kundskab om det aabne Havs Snyltekrebs og Lernæer, m. 15 Tavler. $61 . .5$. 
VI med \& Tavler 1890-92,

1. Lorenz, L. Lysbevagelsen i og uden for en af plane Lysbolger belyst Kugle. 1890............. .

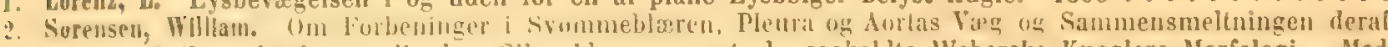
med Hvirvelsujleı saerlig los Siluroiderne, samt de saakalute Weberske Knoglers Morfologi. Med 3 Tavler. Résumé en francais. $1890 \ldots \ldots \ldots \ldots$

3. Tarming, Eug, Lagoa Santa. Lt Bidrag til den biologiske Plantegeografl. Med en Fortegnelse over Lagoa Santas Hvirveldyr. Med 43 lllustrationer i Texten og 1 'lavle. Résumé en français. 1892. . .

VI I med 4 'lavler $1890-94 \ldots \ldots \ldots \ldots$

1. Gram, J.P. Studier over nogle numeriske liunktioner. Résumé en français. 1890............ . .

2. Prytz, K. Melhoder til korte Tiders, særlig Rotationstiders, Udmaaling. Lin experimental Undersegelse.

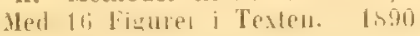

3. Petersen, Eull. Om nogle Grundstolles s allotrope Tilstandsformer. 1891 .............

4. Warming, Eug. Fanilien Podostemaccae. 4de Alhandling, Med c. 185 mest af Forfatteren tegnede Figurer i 34 Grupper. Résumé et explication des figures en francais, $1891 \ldots \ldots$

5. Cbristensen, Odiı T. Rhodanchromammoniakforbindelser. (Bidrag til Chromammoniakforbindelsernes Kemi. [II.) Li?

6. Lülken. Chr. Spolia Atlantica. Scopelini Musei Zoologici Universitatis Ilauniensis. Bidrag til Kundskab om det aabne Hars Laxcsild cller Scopelinel. Med 3 Tavler. késumé en français., 1892 . . . .

7. Pelersen, Einll. On den elektrolytiske Dissociationsvarme af nogle Syrer. 1892....... . . . .

S. Petersen, 0. G. Bidrag til Scitanineernes Anatomi. Résumé en frangais. 1893

9. Lutken, Cbr. Andet Tillag til "Bidlag til Kundskab om Arterne af Slagten Cyamus Latr. eller IIvallusenen, Med 1 Tavle. lésumé en francais, $1893 \ldots \ldots$

10. Petersen, Eull. Reaktionshastigheden ved Methylætherdannelsen. 1894................

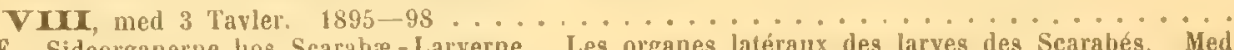

1. Melnert, $F$. Sideorganerne hos Scaraba-Larverne. Les organes latéraux des larves des Scarabés. Med 3 Tavler. Résumé et explication des planches en francais. 1895

2. Peterset, Eull. Damptiyksformindskelsen af Methylalkohol. 1896

3. Huchwaldt. F. En mathenatisk Undersogelse af, hvorvidt Vadsker og deres Dampe kunne have en falles Tilstandsligning, baseret paa en kortiattet Fremstilling af Varmetheoriens Hovedsætninger. Résumé en frangais. Is!l;

4. Haruhg, Lug. Halofyt-Studier $1897 \ldots \ldots \ldots$

5. Johannsen, W. Studier over Planternes periodiske Livsyttringer. I. Om antagonistiske Virksomheder i

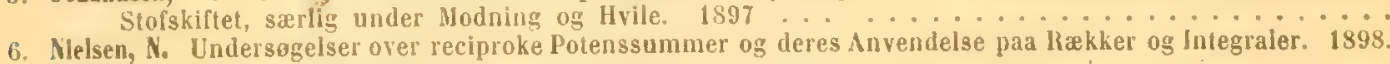
IX, med 17 iuvler. $1898-1901$

1. Steenstrup, Japetus, og Lüken, Chr. Spolia Atlantica. Bidrag til Kundskab om Klump- eller Maneliskene

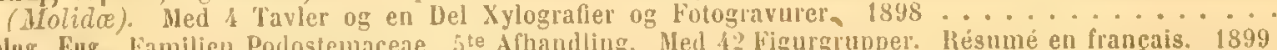

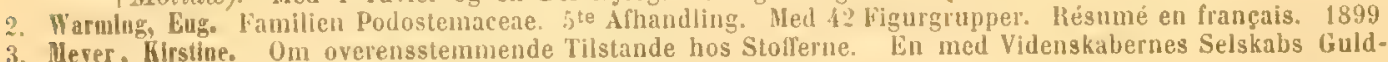

3. Meger, Kirstine, Om overensstemmende Tilstande hos Stollerne. Lin med Videnskabernes Selskabs Guldmedaille belonnet Prisafhandling. Med en Tavle. 1899.

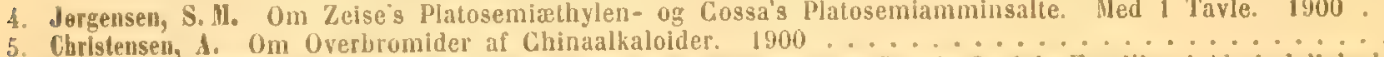

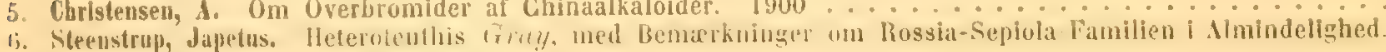
Med en Tivle. 1400

7. Graı, Bllie. Om Proteinkornene hos oliegivende Frs. Med 4 Tavler. Résumé en français. 1901 . . .

8. Ileluert, Fr. Vandkalvelarverne (Larve Dytiscidarimi). Med 6 Tavler. Résumé en francais. 1901 . X. med 4 Tavler. 1899-1902

1. Juel, C. Indledning i Laren om de graflske Kurver. Hésumé en français. 1899.............

2. Butmann, Eluar, Bidrag til de organiske Kivagsolvforbindelsers Kemi. 1901...............

3. Samsoe Lund og Mostrup, E. Marklidselen (Cirsium arvense). En Monograf. Med i Tavler. Résumé en francais. $1: 111$

4. Christensen, A. $0 \mathrm{~m}$ Bronderivater at Chinalkaloiderne og om de gennem disse dannede brintattigere Forlindelser $1 !(1)$

XI, med 10 Tavler 0 g 1 Kort. $1901-03 \ldots \ldots \ldots$

1. Warming, Eug. Familicn Podostemacene. Gte Afhandling. Meil i Figurgrupper. Késumé en francais. 1901.

2. Ravn, J. I. J. Molluskerne i Banmarks Kridtaflejringer. I. Lamelliblancliater. Med 1 Kort og 4 Tavler. 1902.

3. Winther, Chr. Rotationsdispersionen hos de spontant aktive Stoller. 1902.

4. Karu, J. I.J. Molluskelne i Daumarks Kridtaflejringer. 1I. Scaphopoder, Gastropoder og Cephalopoder. W(id is liter 1:i0!

5. Winther, Chr, Polarimetriske Undersogelser II: Rotationsdispersionen I Oplasninger ........... . . . .

6. Marn, J. I.J. Molluskerne i Damarks Kridtaflejringer. II. Stratigrafike Undersogelser. Med 1 Tavle.

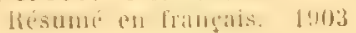

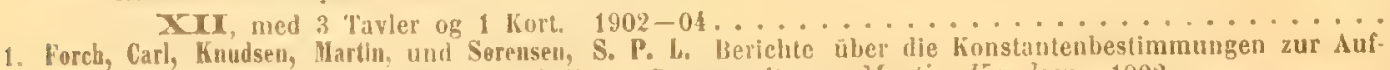
stellung der hydrographischen Tabellen. Gesammelt von Murtin Kinudsen. 1902........

2. Bergb, R. Gasteropoda opishobranchiata. With three plates and a map. (The Danish expedition to Slam 15?3 1:00, I.: $1: 10)$

Petersen, C. G. Joh. Jensen, Soren, Johansen, A. Go, og Lerinsen, J. Chr. Lo De danske liarvandes Plankton, Aarene 1898-1901. 1903

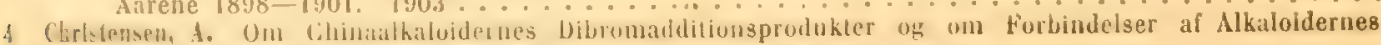

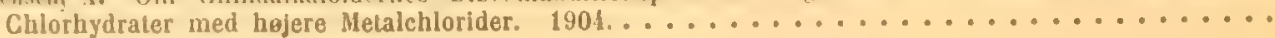

2.

3. 80 .

10. 85.

13. 75 .

1. 10.

1. 50 .

1. 60.

1. 50 .

1. 25 .

3. 50.

1. 25.

2. 75 .

- 85.

1. 50 .

12. 25.

3. 30 .

1.

2. 25 .

3.

3. 75.

160.

17.

1. 75.

I. 60.

2. 60.

- 75.

1.

- $\$ 0$.

2. 50.

5. 35 .

10. $\vdots 0$.

2. 80.

1. 80.

6.

1. 40.

15. 05.

2. 15.

1.

2.

3. 10.

1. 60 .

3. 85.

10. 50 .

1. 75 .

3. 15.

3. 25.

1. 35. 





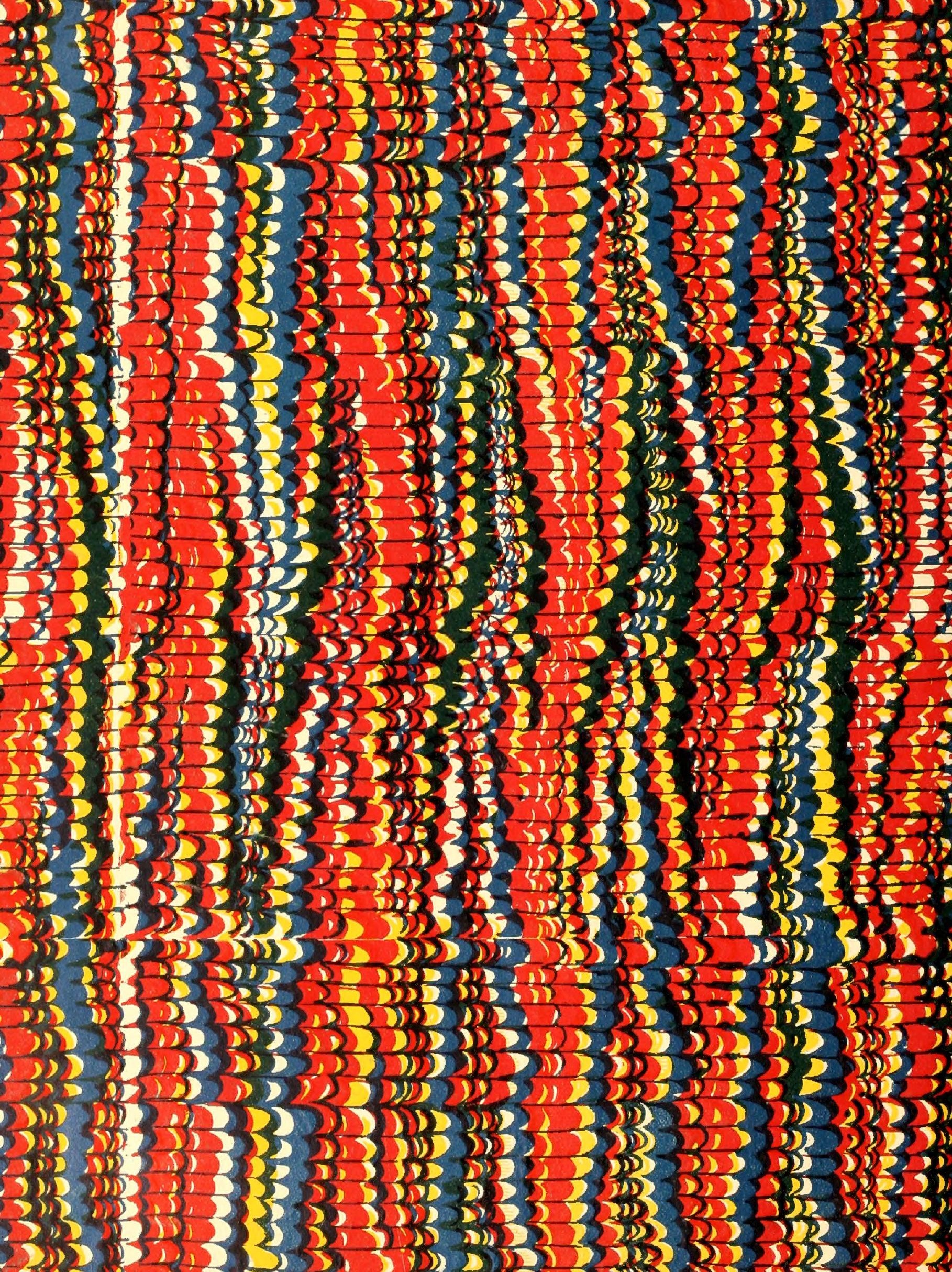


